\title{
ESTUDO DA PERCOLAÇÃO D'ÁGUA EM MACIÇOS ROCHOSOS PARA O PROJETO DE GRANDES BARRAGENS
}

ANTONIO MANOEL DOS SANTOS OLIVEIRA

Dissertação de Mestrado apresentada ao Instituto de Geociências da Universidade de São Paulo. 
UNIVERSIDADE DE SÃO PAULO
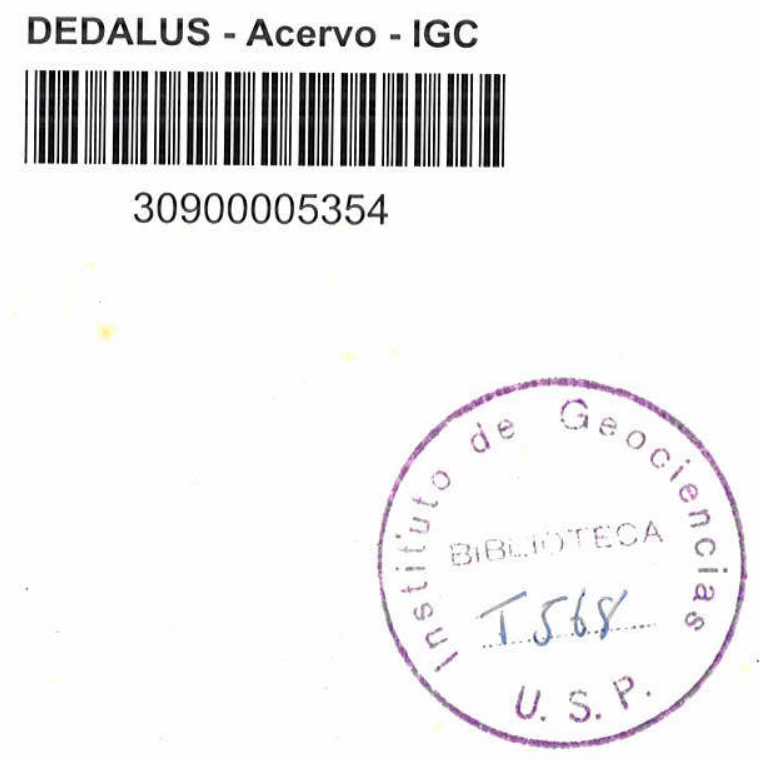

ESTUDO DE PERCOLAÇÃO D'ÁGUA EM MACIÇOS ROCHOSOS PARA O PROJETO DE GRANDES BARRAGENS

ANTONIO MANOEL DOS SANTOS OLIVEIRA

DISSERTAÇÃO DE MESTRADO APRESENTADA AO INSTITUTO DE GEOCIENCIAS SOB ORIENTA ÇÃO DO PROF. DR. JOSE E.S. FARJALLAT 
1ㅡ PARTE: CONCEITOS FUNDAMENTAIS E ESTADO DO CONHECIMENTO

I. - hidRogeologia e hidRogeotechia ................

II. - A HIDROGEOTECNIA EM BARRAGENS ..............

III. - PROPRIEDADES HIDRAULICAS DOS MEIOS NATURAIS ......

III.1. - Meios com porosidade vacuolar ..............

III.2. - Meios com porosidade intersticial ...........

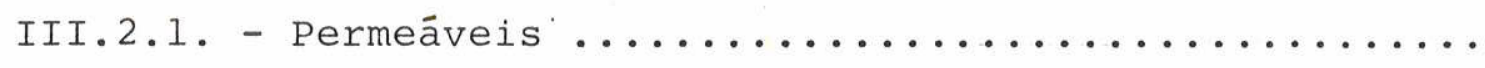

III.2.2. - Praticamente impermeáveis com baixa porosidade.

III.2.3. - Praticamente impermeáveis com alta porosidade..

III.3. - Meios com porosidade de fraturas ............

II.4. - Meios com porosidade de canais ..............

IV. - heterogeneidAde, ANISOtRopiA E FORMAS DE RELEVO

IV.1. - o papel da heterogeneidade ...............

IV.2. - o papel da anisotropia ..................

IV.3. - o papel da forma das encostas................

V. - HIDRAULICA DOS MEIOS FRATURADOS: PROPRIEDADES E COM

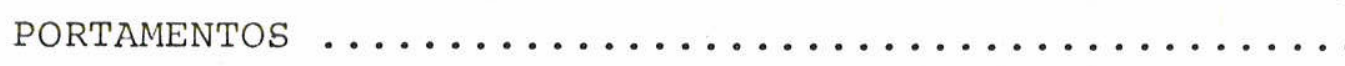

V.1. - Parâmetros hidráulicos do meio fraturado .........

V.2. - A permeabilidade ou a condutividade hidráulica dos

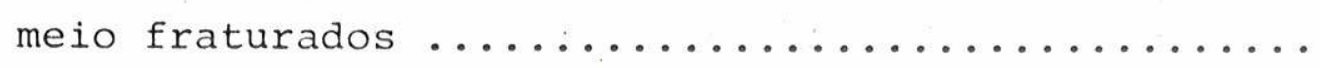

V.3. - Influência das tensões na permeabilidade dos maci

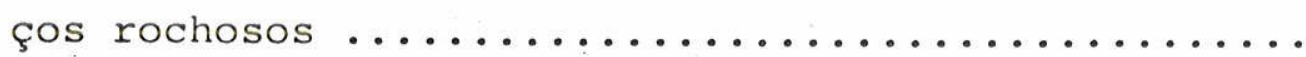


V.3.1. - Características mecânicas dos maciços rochosos de

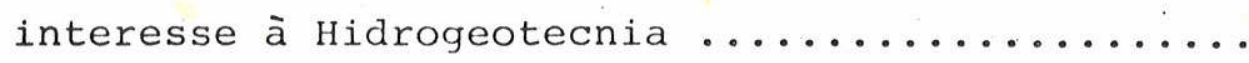

V.3.2. - Relação das tensões com a permeabilidade .......

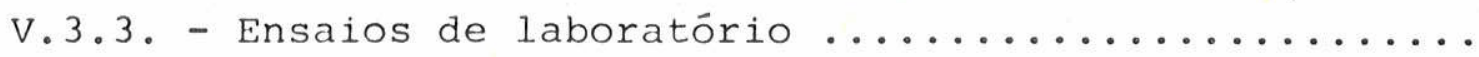

V.3.4. - Ensaios "in situ"

VI. - AS SOLICITAÇÕES IMPOSTAS PELAS BARRAGENS ........

VI.1. - A percolação d'água e a estabilidade das barragens

VI.2. - Tensões induzidas nos maciços pelas barragens ....

VII. - LeVAntAMEnTo hidRogeotécnico de CAMPO ..........

VII.1. - Levantamento de dados de interesse à Hidrogeotec

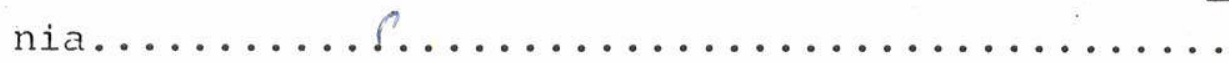

VII.2. - Ensaios de permeabilidade ...............

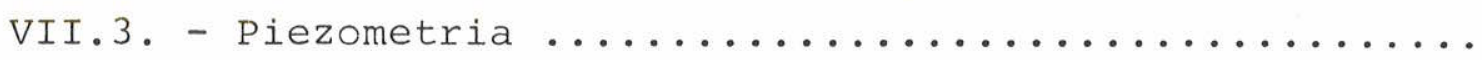

VIII. - ESTUDOS HIDROGEOTÉCNICOS

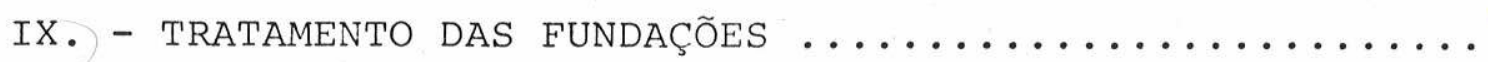

IX.1. - Conceitos fundamentais .................. 70

IX.2. - Um breve apanhado histórico .............. 77

X. - CONCLUSÕES

2 ARTE: PROPOSTA DE METODOLOGIA

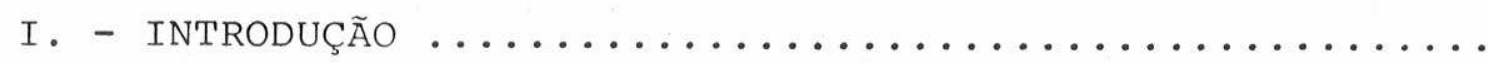

II. - BREVES REFLEXÕES SOBRE A EVOLUÇÃO DA GEOLOGIA A PLICADA A BARRAGENS

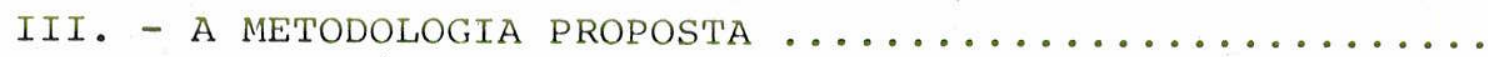


II. - OS BASALTOS DA FORMAÇÃO SERRA GERAL ...........

II.1. - Aspectos genëticos

II.2. - Constituição litológica dos derrames ..........

II.3. - Estruturas principais

II.4. - Condições climáticas ................. 107

II.5. - Aspectos geomorfológicos ................ I I 10

II.6. - Caracteristicas hidräulicas principais ...... 111

II.6.1. - Tipos de porosidade ................ 112

II.6.2. - Permeabilidade ................... 112

II.6.3. - Circulação .................... 116

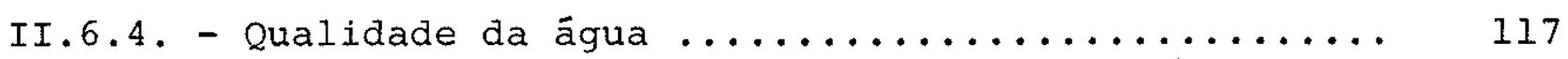

II.6.5. - Caracteristicas mecânicas de interesse à Hidrogeotecnia.. 118

III. - AS BARRAGENS DO TIPO GRAVIDADE .............. 119

III.1. - Projeto ......................... 119

III.1.1. - Hipóteses de subpressão ................ 119

III.1.2. - os tratamentos ................... 124

III.2. - Construção ...................... 127

III.3. - Enchimento do reservatōrio e operação ......... 131

IV. - OS BASALTOS DA FORMAÇÃO SERRA GERAL COMO FUNDAÇÃO DE BARRAGENS DO TIPO GRAVIDADE .............. 132

IV.1. - Etapa de estudos para o projeto ............. 132

IV.2. - Etapa de Construção .................. 136

IV.2.1. - Tratamento das fundações .............. 138

IV.2.1.1. - Injeções ................... 138

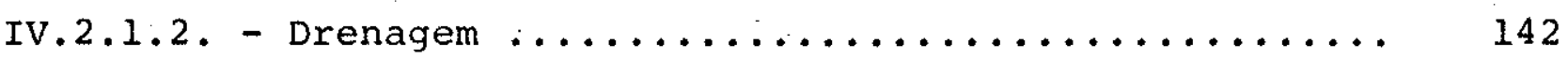


IV.2.3. - Ensaio hidrogeotécnico global..............

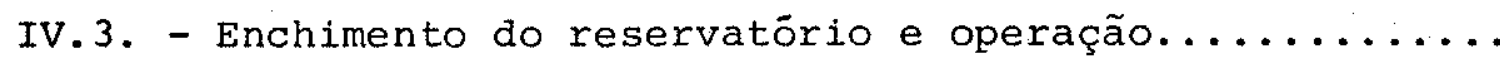

IV.3.1. - O papel das descontinuidades.

IV.3.2. - Condições impostas pela interligação das descon tinuidades através dos drenos profundos..........

IV.3.3. - Condições impostas pelos efeitos da drenagem sü

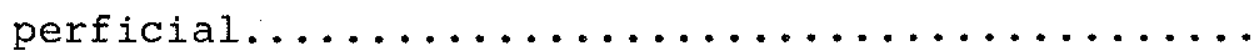

IV.3.4. - Condições impostas pela drenagem das casas de

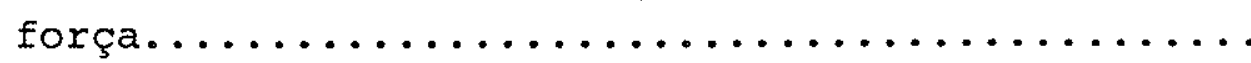

IV.3.5. - A eficiência dos tratamentos................ 154

IV.3.6. - Comparação com as hipōteses de subpressão...... 157

IV.3.7. - Comportamento hidrogeotécnico dos basaltos na zo

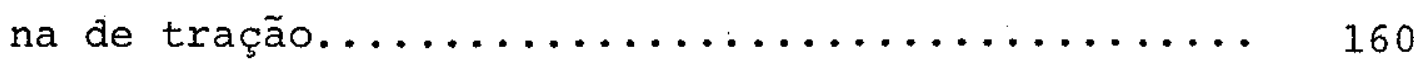

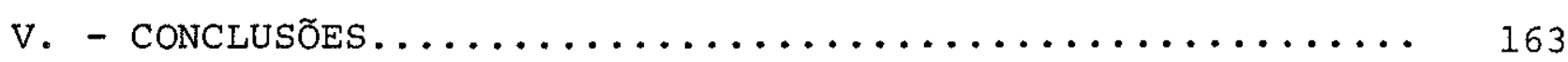

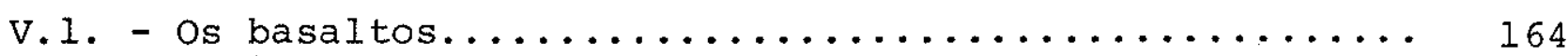

V.2. - As barragens................................ 166

V.3. - o sistema barragem $x$ basalto................. 166

V.4. - Conclusões finais.......................... 168

4 a PARTE: TENDENCIAS NA EVOLUÇÃO DA HIDROGEOTECNIA DE BARRAGENS

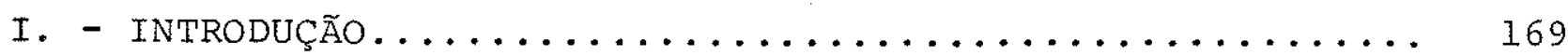

II. - ORIENTAÇõES PARA OS ESTUDOS HIDROGEOTECNICOS E A PRE VISÃO DAS SUBPRESSÕES E DAS VAZÕES............... 171

II.1. - Previsão do comportamento das fundações na zona de

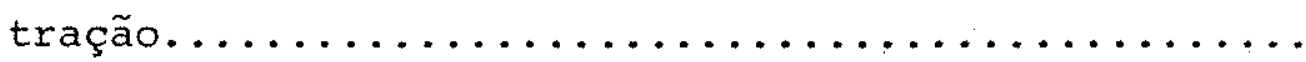

II.2. - Modelos de anālise..................... 176 
pāg.

III. - ORIENTAÇŐES PARA OS TRATAMENTOS DAS FUNDAÇÕES..... 180

III.1. - Vedações......................... 181

III.2. - Drenagem........................ 181

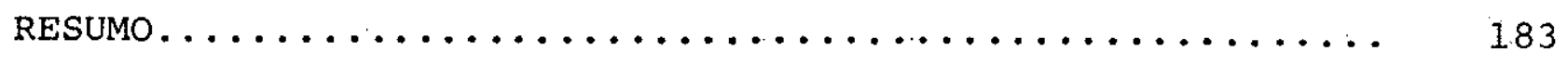

AGRADECIMENTOS.......................... 184

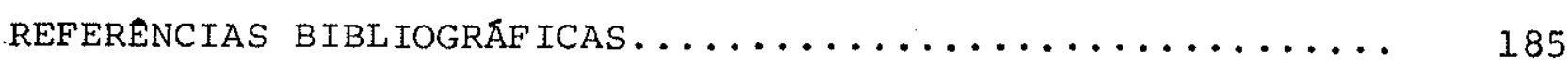


1. - Efeitos da percolação d'água nos maciços de fundação de barrá gens (Modificado de SABARLY, 1970): 09

2. - Ordens de valor de propriedades hidräulicas de alguns meios naturais:12

3. - As descontinuidades nas rochas e maciços rochosos (Modificado de LOUIS, 1974): 25

4. - Exemplos de estudos hidrogeotécnicos em modelos: 68

5. - Valores da permeabilidade obtidos em vários locais de barrạ gens (Modificado de OLIVEIRA, SILVA e GUIDICINI, 1976): 115

6. - Caracteristicas principais das barragens analisadas, segundo - Registro Geral do Comitê Brasileiro de Grandes Barragens Barragens da Companhia Energëtica do Estado de São Paulo S.A.: 129

7. - Relações entre os tratamentos de montante e jusante e os res pectivos níveis d'água (AZEVEDO, OLIVEIRA e SOARES): 296

8. - Orientações para os estudos hidrogeotécnicos. Exemplo para os casos de barragens de gravidade sobre basaltos da Formação Ser ra Geral (AZEVEDO, OLIVEIRA e SOARES, 1978): 178

9. - Técnicas usadas e respectivos objetivos nas diversas fases da barragem, segundo orientações da tabela anterior (Modificado de AZEVEDO, OLIVEIRA A SOARES, 1978): 173

10. - Orientações para o projeto, execução e controle das vedações (Modificado de AZEVEDO, OLIVEIRA e SOARES, 1978):

11. - Orientações para o projeto, execução e controle da drenagem: 182 


\section{FIGURAS: päginas}

1 - Variação da porosidade (1), da porosidade efịcaz (2) e da capa cidade de retenção especỉfica (3) com o diâmetro dos grãos (se gundo Eckis, citado por CASTANY, 1963): 14

2 - o papel da anisotropia no comportamento do fluxo d'água: casos de um talude (DUFFAUT e LOUIS, 1972): 19

3 - Comparação entre os perfis de dois lençoís freãticos e suas respectivas equipotenciais, com uma mesma cota (L) a uma di $\underline{\underline{s}}$ tância infinita do talude. Escoamento para um talude côncavo (a) ou retilineo (b). (DUFFAUT e LOUIS, 1972): 21

4 - A questão da homogeneidade, isotropia e continuidade, resolvida na escala do problema considerado. (Modificado de LouIS, 1974): 23

5 - Modelo mecânico que caracteriza o fenômeno de fechamento das fraturas (LOUIS, 1974): 28

6 - Carregamento de modelo bidimensional descontínuo (KRSMANOVIC e MILIC, 1963): 29

7 - Distribuição teórica de tensões em modelos continuos (C) e des continuos (D) (LONDE e SABARLY, 1967): 31

8 - Esquemas do fraturamento dos maciços rochosos (LOUIS, 1974): 3 b

9 - Ensaio de percolação radial (BERNAIX, 1967): $3:$

10 - Comportamento hidromecânico de um calcārio com ou sem fratura (LOUIS, 1974): $\because 9$

11 - Comportamento hidrodinâmico de uma fratura elementar (natu ral) de granito.' (LOUIS, 1974): :10

12 - Reconhecimento hidráulico, mecânico e geofísico de um local de barragem. ((LOUIS, 1974): 42 
13 - Variação da condutividade hidrāulica em função da profundida dem local da barragem de Grand Maison (LOUIS, 1974): 44

14 - Lei da distribuição do coeficiente de permeabilidade nas con dições naturais. Seção transversal vertical $K=K o \operatorname{Exp}(-A t)$, $\left(\mathrm{K}, \mathrm{cm} / \mathrm{s}\right.$ e $\mathrm{A}, \mathrm{m}^{-1}$ ) (LOUIS, 1974): 45

15 - Esquema das principais forças em jogo nas barragens do tipo gravidade (a) e arco (b): 51

16 - Esquema da distribuição de zonas de tensão nos maciços sob barragens do tipo gravidade (a) e arco (b) : 54

17 - Foto da ombreira direita da barragem de Malpasset (09/04/71) Observa-se a fenda de tração no pé de montante do arco. Esta fenda prolonga-se até a ombreira esquerda:

18 - Subpressões em Malpasset (BELLIER, 1967): 5

19 - Forças de escoamento desenvolvidas sob a ação de tensões (LOUIS, 1969): 58

20 - Efeitos das tensões na percolação (SABARLY, 1971) : 59

21 - Correlação entre a vazão do dreno e o nível do reservatörio (SABARLY, 1974): 60

22 - Esquema de montagem de piezômetro num furo de sondagem: ô?

23 - o papel dos tratamentos de fundação (TER MINASSIAN, SABARLY e LONDE, 1967): 73

24 - Exemplos hipotéticos (CASAGRANDE, 1961) : 7

25 - Comparação esquemätica entre os efeitos ideais da vedação (a) e da drenagem (b): 76

26 - Foto da barragem de Malpasset. Vista de jusante $(09 / 04 / 71): 80$

27 - Foto da barragem de Idbar. Inicio da ruptura da ombreira di reita. (TALOBRE, 1967): 80 
28 - Eficiência teörica de cortinas imperfeitas (CASAGRANDE, 1961): 82

29 - Análise teórica da eficiência de cortinas (LONDE e SABARLY 1967): 84

30 - Ocorrência dos derrames basālticos na bacia do Paraná (adapta do de AMARAL e outros, 1965) e principais barragens em opera ção (o), construção (c) e projeto (p): 98

31 - Perfil tipico de um derrame basáltico: 102

32 - Os dois tipos de basalto: compacto e vesicular lou amigdaloi dal), constituindo respectivamente, em Ilha Solteira, a base do derrame III e o topo do derrame II. Cada um apresenta pa drões diferentes de fraturamento (Canal no leito do rio Para ná, 1974): 103

33 - Basalto compacto da figura anterior tal como ocorre na solei ra do leito do rio Paraná.observa-se o fraturamento vertical: 103

34 - Contato 348 entre dois derrames em Promissão. Vista do muro direito de ligação e escavações para os vertedores (1969): 105

35 - Padrão de fraturamento em basalto compacto do núcleo do derra me principal de Ibitinga: 10.5

36 - Juntas-falhas ou faixas fraturadas na parede da escavação pá ra as tomadas d'água de Ilha Solteira (1969): 106

37 - Detalhe de uma junta-falha ou faixa fraturada (tomadas d'ägua de Ilha Solteira, 1970): 106

38 - Derrame hipotético apresentando suas principais feições lito lögicas e estruturas (modoficado de. OLIVEIRA, SILVA e GUIDI CINI, 1976): 1.08

39 - Barragem de Ibitinga no rio Tietê. Término de construção em 1969: 128 
40 - Escavações na ārea ensecada de Promissão (1968): 128

41 - Fase de concretagem dos blocos na barragem de Ilha Solteira $(1974): 130$

42 - Instalação de meias-canas previamente à concretagem dos blo cos na barragem de Ilha Solteira (19.73): 130

43 - Linhas piezométricas do contato 305 em seção paralela ao eixo da barragem de Água Vermelha (Modificado de SILVA, ARAUJO e MONTICELI, 1978):135

44 - Seção longitudinal esquemätica das fundações das estruturas de concreto da barragem de Promissão (OLIVEIRA e CORREA FILHO, 1976): 144

45 - Resultados do 2 ensaio hidrogeotécnico global na barragem de Promissão (OLIVEIRA e CORREA FILHO, 1976): 146

46 - Acompanhamento hidrogeotécnico do enchimento do reservatório da barragem de Promissão (OLIVEIRA e CORREA FILHO,1976): 149

47 - Subpressões da junta-falha de Ibitinga em seção pelo eixo da barragem (GUIDICINI, OLIVEIRA e MATUOKA, 1970): 150

48 - Seção geológica pelo eixo da barragem de Ibitinga (GUIDICINI, OLIVEIRA P MATUOKA, 1970): 152

49 - Linhas piezomētricas principais em șeção paralela ao eixo da barragem de Promissão: 155

50 - Linhas piezométricas na casa de força da barragem de Promissão (OLIVEIRA O CORREA FILHO, 1976): 158

51 - Quatro seções piezomētricas da junta-falha de Ibitinga no mu ro direito (medidas em 13/07/77): 159

52 - Comparação teórica das distribuições da permeabilidade, em profundidade, entre os maciços basālticos e os intrusivos (OLI VEIRA, SILVA e GUIDICINI, 1976): 165 


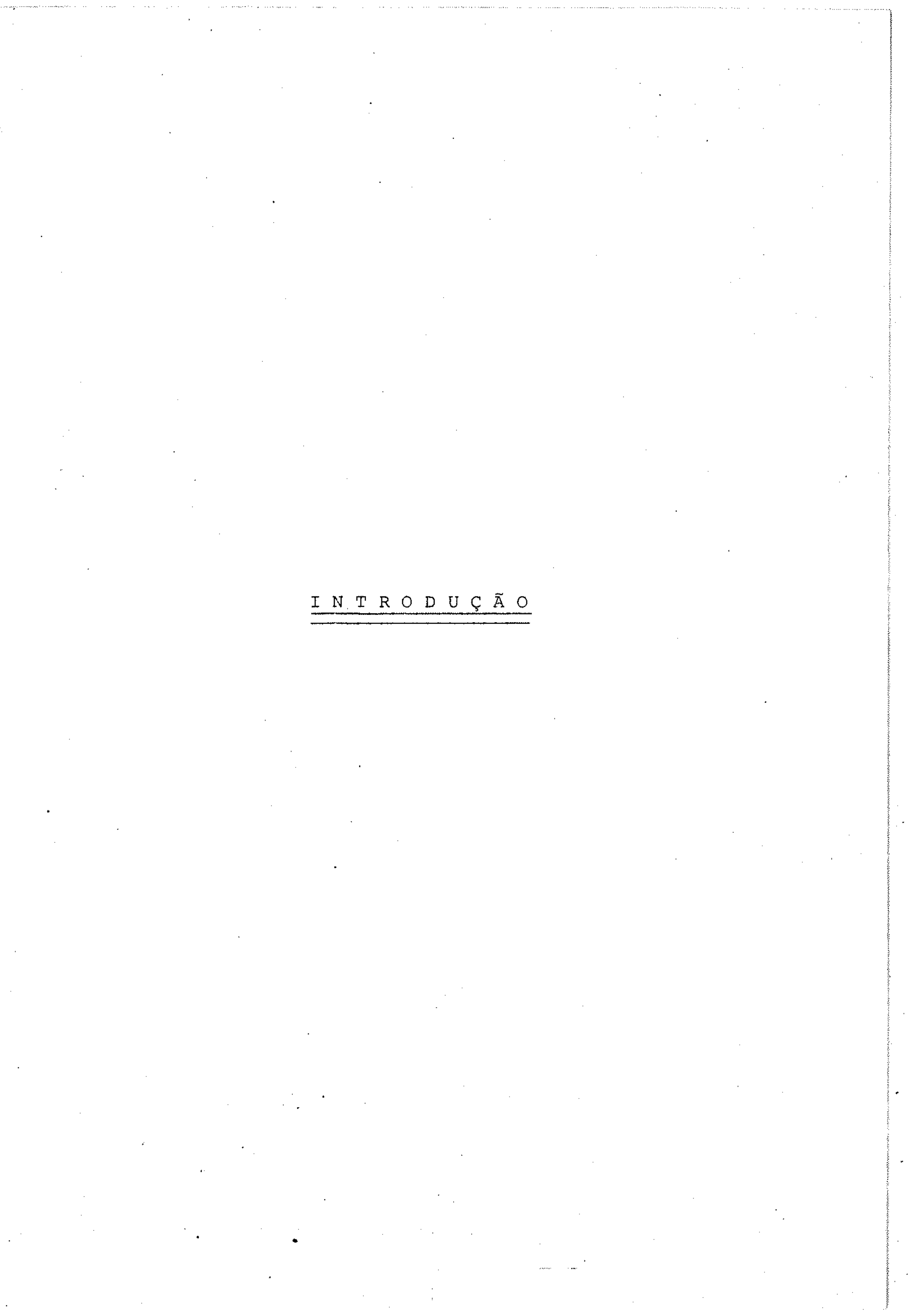


Nos maciços rochosos que servem de apoio às grandes

barra gens $^{(*)}$, os efeitos da percolação d'ãgua são necessariamente leva dos em consideração no projeto. Dentre estes efeitos destacam-se as subpressões por influirem diretamente no cālculo das estruturas das baxragens, em especial as de gravidade.

O conhecimento das subpressões resulta sobretudo da análise e interpretação de acidentes de barragens, onde as subpressões atuaram como causa principal. A primeira análise remonta a 1895 envolvendo a barragem de Bouzey na França. Sucessivas rupturas da estrutura desta barra gem levaram M. Levy (MARY, 1965)

a propor, em fins do século passą do, que fossem consideradas as subpressões que atuam na base das barragens do tipo gravidade em seus projetos. En 1964, o aciden te de Malpasset levou a mesma preocupação para as barragens do tipo arco (BERNAIX, 1967).

Desde então, a evolução da tecnologia da construção de gran des barragens seguiu diversos caminhos. Como um dos mais seguidos, a observação permanente do comportamento das barragens construidas permitiu aprimorar o grau de conhecimento sobre a questão. A partir deste caminho, foram adotados värios critérios e regras de maneira a estabelecer hipóteses de subpressão em projetos .. de barragens de concreto. Inicialmente muito conservadoras, foram sen do reformuladas com base nas medidas de subpressão efetuadas em nu merosas barragens em operação. São conhecidos os critérios de proje tos adotados pelo Tenessee Valley Anthority, pelo U.S.

(*) O conceito de grandes barragens è aquele adotado pelo comitê Brasileiro de Grandes Barragens, ou seja, todas as barragens com mais de $15 \mathrm{~m}$ de altura ou de altura inferior, porém com pelo menos uma das seguintes condições: comprimento de crista igual ou superior a $500 \mathrm{~m}$, reservatório com volume total superior a $100.000 \mathrm{~m}^{3}$, vertedor com capacidade superior a $2000 \mathrm{~m}^{3} / \mathrm{s}$, barragens com difíceis condições de fundação, barragens de projeto não con vencional. 
Bureau of Reclamation e pelo U.S. Corp of Engineers para barragens do tipo gravidade. Estes critérios, como os demais, uma vez adota dos, permitem traçar a linha de subpressões, em seções típicas, transversais às principais estruturas de concreto das barragens (CASAGRANDE, 1961). Contudo, a aplicação destas regras genéricas no projeto das barragens, não tem permitido explorar suficientemen te os comportamentos especificos de cada tipo litológico, ou maci ço rochoso de fundação. Por exemplo, SERAFIM e DEL CAMPO (1965) a presentam os résultados de observação das subpressões em fundações constituidas por litologias tão distintas quanto granitos, areni tos e calcários. Os autores chegam, após discutir a aplicação de métodos analïticos na determinação de subpressões, à seguinte con clusão, entre outras: "Contudo, os problemas especificos associa dos às feigões peculiares a cada local, devem ser considerados em detalhe na determinąão das subpressões nas fundacões das barra gens".

Esta advertência estimula a proposição de um enfoque mais ade quado do problema, ou seja, se faz necessärio considerar não só - tipo de barragem, mas o tipo litolögico que constitui sua fundá ção. Cada tipo..litológico, cada formação.geolögica, tem um compor... tamento hidrogeolögico e hidrogeotécnico prōprio que deve ser consi derado, analisado e interpretado à luz das necessidades do projeto. A proposição desta metodologia de estudo do problema, constitui um dos objetivos principais do presente trabalho.

Apōs uma discussão geral do tena - percolação d'āgua em fun dações de grandes barragerıs - onde se procura destacar os conceitos funda mentais e o estado de conhecimento da questão (la parte da dissertação) a

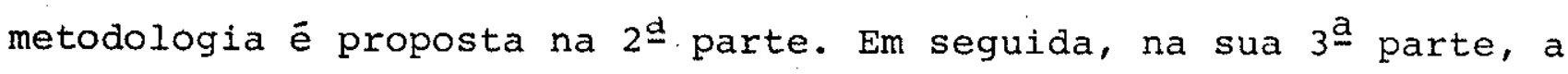
metodologia proposta é aplicada a exemplos brasileiros. Destes, fo ram escoltidas as barragens do tipo gravidade em basaltos por cons 
tituirem, no momento, o tipo de barragem mais frequente e a litolo

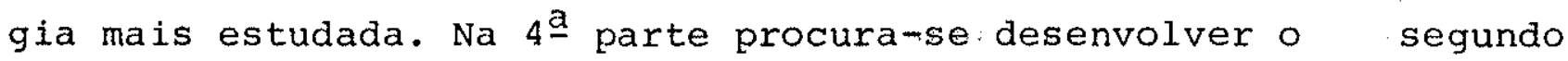
objetivo do trabalho: estabelecer orientações mais adequadas aos estu dos hidrogeotécnicos. Esta ültima proposição resulta do diagnōstí co do estado atual da tecnologia de fundações de barragens.

Paralelamente à evolução dos critērios e regras de projeto, baseada na observação do comportamento das barragens, foram sendo trilhados outros caminhos que possibilitaram um desenvolvimento a preciável de vắrias técnicas de abordagem do problema. O estudo a nalitico dos diversos parâmetros hidräulicos que condicionam a per colação d'àgua nas fraturas è um dos caminhos. Este estudo tem-se baseado em ensaios de laboratōio utilizando modelos de fraturas com parâmetros hidräulicos (sobretudo rugosidade e abertura) contro lados. O objetivo principal de tais ensaios é definir as leis que regem o fluxo d'água em fraturas. Ao contrário dos meios porosos (com porosidade de instersticios) onde os escoamentos, permanentes ou transitórios, em meios homogêneos ou heterogêneos, isōtropos ou anisōtropos, foram intensamente estudados, os fenômenos de escoa mento em meios fraturados, não foram objeto senão de aproximações timidas (LOUIS, 1974). Dentre os mais conhecidos, pode-se citar os: estudos de LOMIZE (1951); LOUIS (1968); SHARP (1970) e MAINI(1971).

Contudo, são inümeras as dificuldades de se transpor os resul tados destes estudos para caracterizar o fluxo d'ägua tal como 으 corre na natureza. As principais dificuldades refletem a distância existen te entre os modelos laboratoriais, necessariamente simplificados, e o com portamento real da percolação d'ägua na natureza. Pode-se exempli ficar considerando-se a difícil determinação, no campo, do grau de extensão das fraturas, da rugosidade e da abertura média. Assim, apesar de todo o progresso teórico, a natureza ainda se coloca 
quase inacessivel à aplicação direta desse esforço realizado.

Por outro lado, desenvolveram-se modelos de anälise que se apoiam em técnicas mais ou menos sofisticadas.. Tais modelos com preendem os eletro-analögicos (HABIB e SABARLY, 1953),

(FRANCIS, 1970), os hidráulicos e os matemáticos, estes através de elementos finitos, desenvolvidos em computador (LOUIS, 1974). o aperfeiçoa mento destas técnicas de anālise abre um caminho promissor para o estabelecimento de hipóteses de subpressão mais realistas. Tais tēcnicas permitem não só levar em conta uma série de fatores espe cificos ao sistema obra $x$ meio físico, que pode inclusive ser tra tado como um problema tridimensional, mas sobretudo simular as di versas fases da obra até o enchimento do reservatório e portanto, prever o estabelecimento das subpressões.

Com estas técnicas poder-se-ia portanto prever um deslocamen to importante do ponto central da questão: da adoção de critêrios e regras de projeto, para o estudo e aplicação das técnicas de a nálise em modelos. Contudo, o aperfeiçoamento destas técnicas não está sendo proporcionalmente acompanhado pelas tëcnicas de caracte rização dos maciços rochosos in situ. Esta situação traduz uma con tradição fundamental uma vez que a definição dos modelos só pode ser realizada com os dados da caracterização dos maciços naturais ou; em outras palavras, não se justifica o uso de modelos se não se dispõe de dados suficientes sobre o meio fisico estudado. Para se corrigir esta situação não se pretende apontar, como solução, - aperfeiçoamento das tēcnicas de investigação do meio físico no sentido de uma maior sofisticação. O que se torna premente, como primeiro passo, è melhor orientar os levantamentos de dados do meio fisico, o que significa estabelecer uma metodologia mais adequada a esse fim, com as tēcnicas atualmente disponíveis. A a doção dessas orientações provocará o aperfeiçoamento espontâneo 
das tēcnicas de caracterização do meio físico, minimizando a con tradição constatada e permitirá, em condições favoráveis para sua aplicação, substituir a adoção de regras genëricas para o estabele cimento de hipöteses de subpressões pela previsão do comportamen to hidrogeotécnico.

Em resumo, a dissertação tem dois objetivos principais. Pri meiro, desenvolver a metodologia proposta para um enfoque mais ade quado da questão: anālise do problema considerando-se não só o tí po de solicitação imposta ao meio físico (barragem do tipo gravida de, por exemplo) mas o tipo de resposta resultante do meio físico considerado (basaltos da Formação Serra Geral, por exemplo). Assim, a aplicação da metodologia é exemplificada atravês de um estudo de sintese da experiência brasileira. Em segundo lugar, como resulta do do diagnóstico do estado atual dos estudos teóricos sobre perco lação e de modelos de anālise, traçar as principais orientações dos estudos hidrogeotécnicos e em especial aqueles realizados no campo.

o desenvolvimento da dissertação reforça o papel fundamental da aplicação da Geologia aos estudos necessārios ao projeto e cons trução de barragens, o que.corresponde a novas tendências de evo lução da Geologia de Engenharia no pais.

Deve-se finalmente ressaltar que o enfoque metodológico pro posto lsolicitagões de obras especificas $x$ comportamento de forma fões geotógicas especificas) favorece o acúmulo adequado da expe riência, para a constituição de bancos de dados, cuja utilização è extremamente frutifera para o desenvolvimento tecnológico. 
I

CONCEITOS FUNDAMENTAIS

E

ESTADO DO CONHECIMENTO 


\section{I. - HIDROGEOLOGIA E HIDROGEOTECNIA}

Pode-se considerar que estes dois campos de estudo integram a Hidräulica Subterrânea (LOUIS, 1974). Este ramo do conhecimento está voltado para os vâ rios aspectos da āgua subterrânea na crosta terrestre: sua ocorrência, sua evo lução, seu aproveitamento, seus efeitos na dinâmica geolögica superficial. A Hi drogeologia e a Hidrogeotecnia são orientadas em direções diferen tes segundo seus respectivos objetivos e pelas escalas dos fenôme nos estudados. A Hidrogeologia está significativamente voltada pa ra o estudo dos recursos d'água: potencialidades dos aquíferos, seu aproveitamento, sua produtividade, sua proteção, etc, tendendo a estudar os fenômenos na escala das formações geológicas. A Hi drogeotecnia se preocupa com o papel da água no campo geotécnico, analisando seus efeitos nas obras civis, sobretudo mecânicos, e seu papel nos fenōmenos de superficie como os de movimentação de massas (escorregamentos, boçorocas, etc)... escala de aplicação da Hi drogeotecnia é definida sobretudo pela escala das obras e dos fenômenos analisa dos. Contudo, esta fronteira entre a Hidrogeologia e a Hidrogeotecnia não é nî tida. Mais do que a escala de estudo, a fronteira se reforça na definição dos respectivos objetivos de aplicação. Outros aspectos da questão são assinalados por LOUIS (1974) e RAT (1974).

Ainda assim, deve-se considerar que todos os problemas de Hidrogeotecnia, se inserem num contexto hidrogeológico. Assim, por exemplo, para que se possa prever os efeitos de implantação de uma barragem no regime de äguas subterrāneas, o problema hidrogeotécni co gerado por tais obras, deve ser examinado num quadro mais amplo, hidrogeológico. Esta colocação se reforça nos estāgios iniciais de estudo onde é necessārio compreender a dinâmica natural da hidräulica subterrânea para se poder prever as consequências da obra, no tem po e no espaço. Portanto, deve-se considerar que os dois campos de estudo antes se complementam no conjunto de conhecimentos e es 
Os efeitos da percolação d'água nos maciços de fundação de barragens são variados como indica a tabela 1 .

Devem ainda ser consideradas as condições especiais da estabi lidade de ombreiras provocadas por regimes transitórios quando de oscilações räpidas dos níveis do reservatörio. o esvaziamento räpido proporciona o aparecimento de forças de percolação perigo sas, dirigidas para fora do maciço. O. enchimento é ao contrário, um fenômeno estabilizador, quanto às forças de percolação.

E interessante ressaltar algumas idéias introduzidas por DUFFAUT e LOUIS (1972). "Os recipientes destinados a reter liqui dos são construídos de uma só pesa em materiais resistentes, metal ou plástico, ou são formados por um conjunto, no qual, certos ele mentos trabalham a tracão: anéis de barris, ferragens de reservató rios de concreto. Os relevos naturais da crosta terrestre (e tam bém os depósitos artificiais de solos, "stock-piles", bota-foras) são desprovidos de resistência à trąão desde que se uttrapasse a escala do grão ou do bloco. Suas fissuras e intersticios consti tuem sempre um recipiente, onde o nivel d'ägua, varia em funcão das condifões hidrometeorológicas, tão mais räpido quanto seu volu me relativo - a porosidade-é menor. A superficie livre da ăgua não $\ddot{e}$ horizontal nas paredes desses recipientes pois eles não são estanques".

"... toda barragem è um modezo de encosta, todas as discus sões sobre a estabilidade das barragens se aplicam igualmente às encostas. Reciprocamente toda encosta se comporta portanto como uma barragem, em relaşão à àgua subterrânea, onde os materiais não foram nem escolhidos nem dispostos de uma forma que assegure a es tabilidade".

Os tratamentos, vedação e drenagem, propostos para asse gurar a estabilidade dos maciços, atuam nas condições hi 


\begin{tabular}{|c|c|c|c|}
\hline \multicolumn{2}{|c|}{ EFEITO } & DEVIDO A & $\begin{array}{l}\text { ENVOLVENDO } \\
\text { DIRETAMENTE A }\end{array}$ \\
\hline \multicolumn{2}{|c|}{$\begin{array}{l}\text { FISICO } \\
\text { QUIMICO }\end{array}$} & 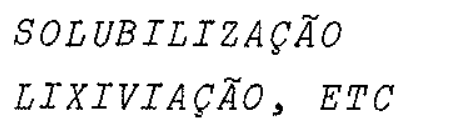 & $A L T E R A C \widetilde{A O}$ \\
\hline \multirow{3}{*}{$\begin{array}{l}M \\
E \\
C \\
\AA \\
N \\
I \\
C \\
O\end{array}$} & ESTÁTICO & $\begin{array}{l}\text { SUBPRESSÕES } \\
\text { FORÇAS DE PERCOLACẼO }\end{array}$ & $E S T A B I L I D A D E$ \\
\hline & DINAMICO & VELOCIDADES & EROS $\tilde{A} O$ \\
\hline & ECONO̊MICO & PERDAS $D^{\prime} \overrightarrow{A G U A}$ & ECONOMIA \\
\hline
\end{tabular}

Tabela 1 - Efeitos da percolação d'água nós maciços de fundação de barragens (Modificado de SABARLY, 1970). 
dráulicas do meio para controlar os efeitos devidos à percolação d'ãgua, especialmente os efeitos mecânicos.

Portanto, a compreensão do comportamento dos meios naturais, destinados a constituir as fundações e as ombreiras de barragens, quanto à percolação d'água e o papel das forças que atuam nos maciços, é in dispensável à adoção dos dispositivos de tratamento adequados. Ao contrārio, arrisca-se não só a adoção de dispositivos tão inúteis quanto onerosos e, o que é mais grave, ilusōrios quanto à segurança.

Deve-se por fim ressaltar que somente uma constante vigilância da percolação d'āgua nas fundações, apōs a construção da barragem, pode assegurar o equilibrio do conjunto obra $\mathrm{x}$ meio físico.

\section{III. - PROPRIEDADES HIDRAULICAS DOS MEIOS NATURAIS}

Antes de se orientar a dissertação para os problemas específicos dos maciços rochosos como fundações de barragens è importante esboçar um quadro geral dos comportamentos dos meios naturais, solos e ro chas, frente à percolação d'água. A caracterização destes compor tamentos pode ser feita, de maneira teórica, considerando homogê neos e isótropos os meios naturais e classificando-os segundo a interrelação de duas propriedades hidráulicas fundamentais: a poro sidade e a permeabilidade à àgua ${ }^{(*)}$.

Quatro tipos bäsicos de porosidade podem ser considerados para caracteri zar a natureza dos vazios dos maciços naturais (SCHOELIER, 1962): vacuolar, in tersticial, de fraturas e de canais. A formação destes tipos de vazios es tá intimamente relacionada à origem dos maciços e sua histōria geo

(*) Embora alguns autores venham atualmente adotando o termo "eonäu tividade ilidräulica", a permanência e o amplo uso do termo "per meabilidade" no meio técnico sugere que este seja mantido pelo menos como sinônimo. 
lógica. Evidentemente, ocorrem sempre associados vários tipos de porosidade num mesmo meio. A porosidade de intersticios e a todos os meios naturais, no entanto os efeitos de outro tipo de porosidade presente podem determinar um comportamento mais signifi cativo, para a escala e o tipo de fenômeno considerado.

Na tabela 2 , procura-se classificar alguns exemplos de meios natu rais segundo a porosidade e a permeabilidade à ägua. As ordens de valor das propriedades, nos exemplos, são apresentados unicamente com a in tensão de se comparar uns com os outros.

\section{III.1. - Meios com porosidade vacuolar}

São meios cuja porosidade è fechada, ou seja, os poros não se comunicam entre si e assim sendo, tampouco com o exterior. Desta for ma, mesmo que tal porosidade seja elevada, a porosidade efetiva é aproximadamente nula, sendo o meio praticamente impermeável.

Os melhores exemplos de tal meio são os basaltos vesiculares e as pedras-pomes (porosidade primária). Hā rochas sedimentares que tambëm apresentam porosidade vacuolar, por exemplo arenitos con chíferos que perderam fósseis por dissolução, portanto porosidade secundāria ou originada apōs a formação da rocha.

\section{III.2. - Meios com porosidade intersticial}

são os meios cuja porosidade, aberta, representa o conjunto dos vazios existentes entre os elementos formadores da rocha. A po rosidade depende sobretudo do arranjo espacial que esses elementos tomam na constituição da rocha.

A estes meios pertencem os solos em geral, os cascalhos, as areias, os siltes, as argilas e rochas como arenitos mais ou menos cimentados, etc. Rochas cristalinas, como o granito, tambëm pos suem uma porosidade intersticial que define a permeabilidade da 


\begin{tabular}{|c|c|c|c|c|c|c|}
\hline MEIOS & $\begin{array}{c}\text { POROSIDADE } \\
\text { PREDOMINANTE }\end{array}$ & $\begin{array}{l}\text { EXEMPLO DE } \\
\text { MEIO NATURAL }\end{array}$ & $\begin{array}{c}\text { POROSIDADE } \\
(\%)\end{array}$ & $\begin{array}{l}\text { CAPACIDADE DE } \\
\text { RETENCÃO }\left(\frac{8}{8}\right)\end{array}$ & $\begin{array}{l}\text { POROSIDADE } \\
\text { EFETIVA }(\%)\end{array}$ & $\begin{array}{c}\text { PERMEABILIDADE } \\
\mathrm{cm} / \mathrm{s}\end{array}$ \\
\hline \multirow{3}{*}{ 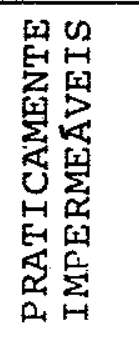 } & VACUOLAR & $\begin{array}{l}\text { BASALTO } \\
\text { VES I CULAR }\end{array}$ & 30 (a) & 30 & $\sim 0$ & $10^{-8}$ \\
\hline & INTERSTICIAL & $A R G I L A$ & 35 (b) & 35 & $\sim 0$ & $10^{-9}$ \\
\hline & DE FRATURAS & XISTO & 0,5 & 0,5 & $\sim 0$ & $10^{-8}$ \\
\hline \multirow{3}{*}{ 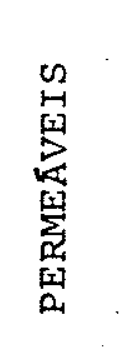 } & INTERSTICIAL & ARENITO & 35 & 5 & 30 & $10^{-3}$ \\
\hline & DE ERATURAS & $\begin{array}{l}\text { GRANITO } \\
\text { FRATURADO }\end{array}$ & 0,1 (c) & 0,05 (d) & 0,05 & $8 \times 10^{-2}$ \\
\hline & DE CANAIS & $\begin{array}{l}C A L C \bar{A} R I O \\
C \bar{A} R S T I C O\end{array}$ & 0,1 (e) & 0,002 & $\sim 0,1$ & - \\
\hline
\end{tabular}

(a) Muito variável em função da densidade de vesículas. Ém estrutura púmice chega a atingir 87\% - (SCiło:ILER,1962).

(b) Em argilas pouco comprimidas, com estrutura em flocos por exemplo, pode atingir 90\%. Se se consideram argilas expansiveis a porosidade total (intersticial + coloidal + reticular) pode atingir 2908 (SCHOELIER, 1962).

(c) Muito variável em função do grau de fraturamentó. O valor dadocorresponde à urau de uma fraturä plana, de $1 \mathrm{~mm}$ de abertura, paralela às faces de um cubo de $1 \mathrm{~m}^{3}$ de volume unitario de rocha.

(d) Considerando-se que cada face da fratura observada em (c) é capaz de reter uma lâmina d'água de 0,25 rm de espessura ( SCHOELLER, 1962).

(e) Muito variāvel em função do grau de carstificação. o valor dado corresponde à porosidade de um volu me unitärio de $1 \mathrm{~m}^{3}$ de rocha cortado por um conduto cilíndrico de $\varnothing=35 \mathrm{~mm}$ e $1 \mathrm{~m}$ de comprimento.

Tabela 2 - Ordens de valor de propriedades hidräulicas de alguns meios naturais 
matriz, interessando em particular problemas de alteração, mas de efeitos secundários na percolação d'ãgua no maciço cristalino, frente à permeabilidade das fraturas.

As argilas destacam-se no grupo por seu comportamento singu lar: mesmo com elevada porosidade são, em geral, praticamente im permeáveis. Nos outros meios, às maiores porosidades quase sem pre correspondem maiores permeabilidades. Tal fato é traduzido pe la relação da capacidade de retenção com o tamanho das partículas, como pode ser observado na figura 1.

Pode-se admitir 3 subgrupos de meios: permeáveis, praticamen te impermeäveis com baixa porosidade e praticamente impermeáveis com elevada porosidade.

III.2.1. - Permeāveis

Nestes meios a capacidade de retenção è bem menor que a das argilas e tanto menor quanto maior o diâmetro dos grãos. o exemplo típico è a areia.

Além do grau de compacidade, interfere na porosidade a forma dos grãos e o coeficiente de uniformidade (d60/dl0).

Em principio, pode-se correlacionar a porosidade de uma areia com sua origem. Assim, é de se esperar que areias eólicas, por e xemplo, sejam mais porosas que areias de origem fluvial, pois as primeiras devem ter um coeficiente de uniformidade menor que as segundas. Tal característica se deve não só ao fato das areias eó licas serem formadas por retrabalhamento de areias de outra ori gem (marinha, fluvial ou glacial) passando portanto por nova sele ção, mas também pelo fato de ser o trabalho do vento mais seleti vo que o da água. Contudo, a totaliaade da histōria geológica das formações é que imprimirá à litologia uma maior ou menor porosidą de, dependendo da superimposição de uma sërie de fenômenos tais co 


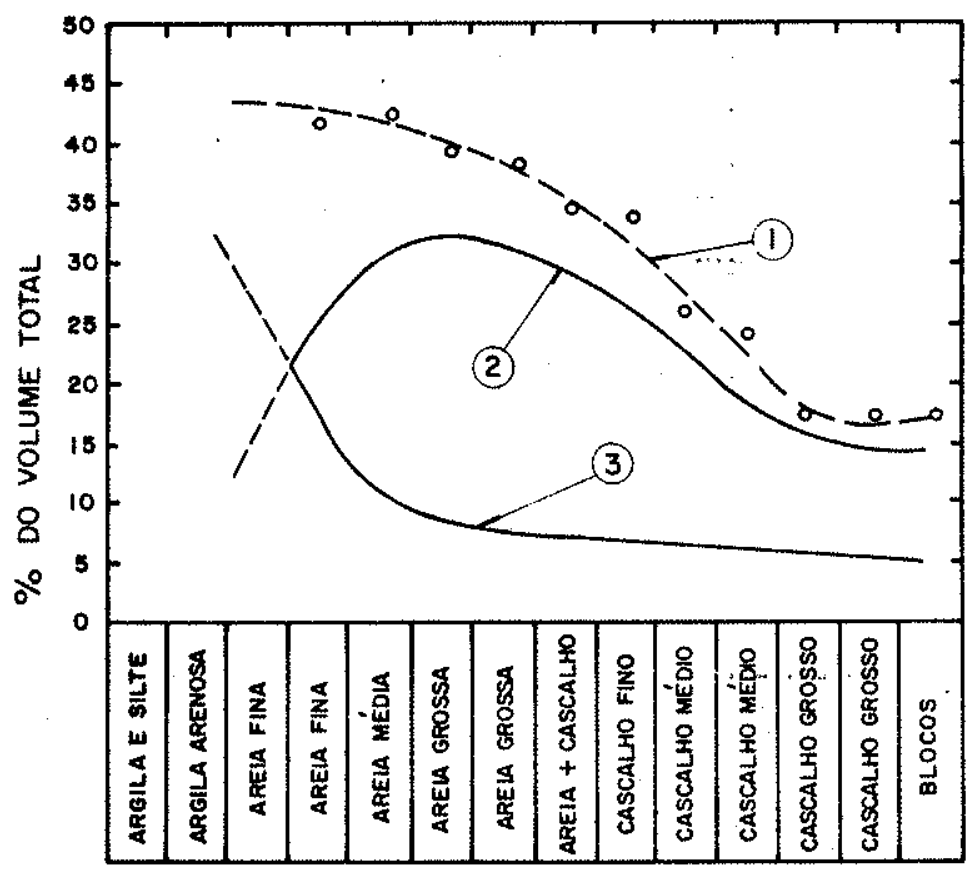

Figura 1 - Variação da porosidade (1), da porosidade efetiva (2) e da capacidade de retenção especifica (3) com o diâ metro dos grãos (Segundo Eckis, citado por CASrianY,1963). 
mo

a cimentação.

III.2.2. - Praticamente impermeáveis com baixa porosidade

Enquadram-se neste subgrupo, por exemplo, os quartzitos e are nitos mais ou menos cimentadọs. Se a cimentação é completa a poro sidade é determinada pela porosidade do cimento, menos o espaço 0 cupado pelos grãos.

III.2.3. - Praticamente impermeāveis com alta porosidade

são meios cuja porosidade efetiva é praticamente nula. A argi la constitui o exemplo típico. A porosidade elevada é dada pelos seus intersticios que devem ter forma lamelar e dimensões próximas ao das partículas argilosas. Tal porosidade é função sobretudo do grau de adensamento da argila. Argilas não adensadas ou consolida das guardam ainda grande quantidade de água nos interstícios de uma estrutura em flocos ou favos. Nestas, a porosidade atinge por vezes $90 \%$

Sendo extremamente sensĩveis à compressão pode-se verificar que sua porosidade diminui gradualmente com a profundidade. Segun do Athy, 1930 (SCHOELER, 1962) a variação da porosidade $\underline{\text { n com a }}$ profundidade $\underline{\mathrm{h}} \ddot{\mathrm{e}}$ :

$$
n=n_{0} \cdot e^{-b h}, \text { sendo }
$$

$n_{0}$ a porosidade média das argilas na superficie e $\underline{b}$ uma constante. Ainda segundo Athy a porosidade mëdia das argilas, sendo de 45 a $50 \%$ em superficie, diminuiria para 25 a $30 \%$ a $300 \mathrm{~m}$ de profundida de. Em areias, a compressão tem pouco efeito sobre a porosidade.Es ta só poderia ser diminuỉa, notavelmente, pelo esmagamentc dos grãos.

Se considerarmos a embebição coloidal e reticular numa argila expansivel a porosidade total pode atingir $290 \%$ em relação ao volume inicial da amostra (SCHOELER, 1962). No 
entanto, materiais como argila, algumas margas e folhelhos, apesar de possuirem alta porosidade, apresentam uma porosidade efetiva ou uma capacidade de escoamento livre (sperific yis lil) quase nula de vida à dimensão dos poros. Assim, a permeabilidade de uma argila varia, de maneira geral, de $10^{-7}$ a $10^{-10} \mathrm{~cm} / \mathrm{s}$.

\section{III.3. - Meios com porosidade de fraturas}

A principal caracteristica que os distinglle dos meios com po rosidade intersticial è a forma dos vazios: suas dimensões longitu dinais são muito superiores à sua abertura. Os meios que podem ad mitir porosidade de fraturas são meios que possuem certo grau de coerência ou coesão, são os meios correntemente conceituados como rochas ou maciços rochosos em Geologia de Engenharia (GUIDICINI, CAMARGO e OLIVEIRA, 1970). São exemplos de litologias deste tipo as rochas cristalinas em geral: granitos, gnaisses, xistos, basal tos, etc. Como o meio com porosidade de fraturas constitui oobjeto prin cipal da dissertação, suas caracteristicas serão detalhadas no item $V$ a seguir.

\section{III.4. - Meios com porosidade de canais}

A porosidade de canais existe tipicamente em rochas solüveis como o calcário e o gipso. Nestes meios a circulação preferencial é responsāvel pela dissolução da rocha em canais. De início a per colação pode ser feita atravēs de interstícios ou fissuras. Mais a circulação se concentra, mais os canais se alargam. Esta concentra ção da percolação ou circulação preferencial e a principal caracte ristica do meio de porosidade de canais.

As dimensões desses canais são extremamente variāveis, desde simples passagens filiformes até grandes condutos da ordem de deze nas de metros de diâmetro. São extremamente irregulares na forma, apresentando estrangulamentos e alargamentos bruscos ou graduais, podendo ainda se dividir ou se anastomosar. 
Meios com porosidade de canais admitem, com maior frequência que outros meios, lençōis d'āgua sob pressão e escoamento em regi me turbulento.

\section{IV. - HETEROGENEIDADE, ANISOTROPIA E FORMAS DE RELEVO}

A caracterização de comportamentos dos meios naturais, efetua da no item anterior, considerou-os como homogêneos e isótropos por necessidade de simplificação. Contudo, na natureza raramente esses meios se apresentam dessa forma, especialmente na escala de análi se de problemas geotëcnicos. As condições de heterogeneidade e ani sotropia que afetam as propriedades hidräulicas produzem efeitos significativos na percolação d'ägua, seja nas pressões hidráulicas, seja nas vazões. Alëm destas condições intrinsecas da natureza dos meios naturais, a morfologia do meio analisado tambēm atua de ma neira importante na percolação d'água.

Assim como as propriedades intrinsecas dos meios naturais, suas condições de heterogeneidade e anisotropia são fruto da histó ria geológica dos meios considerados. Formações sedimentares, por exemplo, em que são comuns as intercalações de lentes arenosas e argilosas, apresentam um certo grau de heterogeneidade, fruto das condições impostas pelos ambientes de sedimentação. A compactação, fenômeno comum dos processos de litogênese, induz uma certa aniso tropia nas formações sedimentares. Da mesma maneira, as formas de relevo, em especial a forma das encostas, são impostas pela evolu ção geomorfológica dos meios naturais considerados.

A seguir, expõe-se, resumidamente, o papel de cada uma destas condições, deixando-se a condição de descontinuidade para ser tratada com mais detalhe no item $V$, que se refere especificamen te aos maciços rochosos fraturados. 
IV.1. - opapel da heterogeneidade

A heterogeneidade natural dos meios, criada por diferenças litológicas e por estruturas geológicas, interfere na distribuição de pressões hidrostáticas e foŕças de percolação segundo o contras te das permeabilidades envolvidas. As equipotenciais se concentram nas zonas menos permeáveis e se afastam nas outras. No entanto, ne nhuma lei geral pode ser estabelecida, dependendo esta configura ção, essencialmente, da situação geométrica de cada caso em parti cular.

Por outro lado, é preciso lembrar que as vazões e velocidades não dependem senão dos valores absolutos das permeabilidades em jo go.

IV.2. - O papel da anisotropia

A permeabilidade de meios anisotrópicos, nos casos mais ele mentares, corresponde a apenas duas componentes perpendiculares entre si. Nestes casos, SHARP (1970) demonstrou que, para condi ções limites constantes, toda superficie do lençol, incluindo a linha de ressurgência, é sempre elevada pela anisotropia, tanto mais quanto maior é a relação entre as componentes, como mostra ... a figura $2(a)$.

Nas figuras $2(\mathrm{~b})$ e 2 (c) são dados exemplos de casos extremos de anisotropia, condicionando diferentes distribuições de equipo tenciais. DUFFAUT e LOUIS (1972) assinalam que, em relação aos meios isótropos; os empuxos d'ägua em maciços com fraturas sub-ho rizontais, como é o caso de muitas rochas sedimentares não dobra das, torna-se estabilizadora. Nos casos contrários eles concorrem para a instabilidade. 

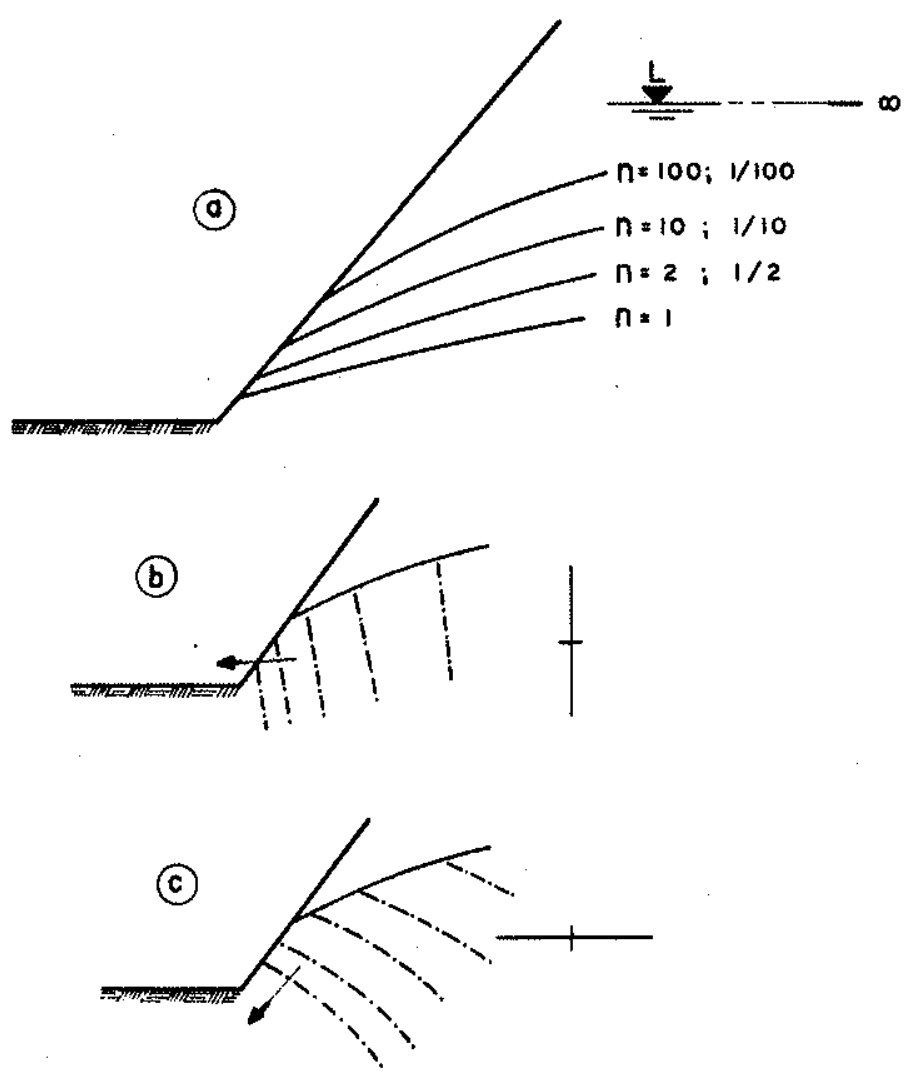

$I=$ posição do lençol freático, ao in inito (condições de contornocons tantes)

$\mathrm{n}=$ relação entre as permeabilidades

(a) =lençóis freáticos, próximos ao ta lude, para diferentes relações de $\bar{n}$ ou $1 / n$

(b) $e(c)=$ situação das equipotenciais e direçao das forças de percola ção nos casos extremos de per meabilidade máxima vertical $(b)$ e horizontal (c).

Figura 2 - o papel da anisotropia no comportamento do fluxo d'á gua: casos de um talude (DUFFAUT e LOUIS, 1972). 
IV.3. - O papel da forma das encostas

Em encostas, as concavidades das curvas de nivel do terreno (suposto homogêneo e isótropo) provocam um escoamento convergente, elevando o lençol aquífero, concentrando, nas vizinhanças da encos ta, as equipotenciais, a vazão e as forças de escoamento. Ao contrā rio, nas convexidades, o escoamento se apresenta divergente, o lençol se abaixa, as equipotenciais se afastam, as vazões e as for ças de percolação diminuem.

E importante observar que os casos de concavidade tendem para um limite extremo que é um poço para onde converge todo fluxo e os casos de convexidade para um cilindro rochoso drenado por to dos os lados. A figura 3 ilustra o papel da forma das encos tas.

V. - HIDRAULICA DOS MEIOS FRATURADOS: PROPRIEDADES E COMPORTAMENTOS

Em Hidrogeotecnia o termo meio fraturado é utilizado para i dentificar os meios cuja porosidade predominante, em termos hi dráulicos, corresponde às fraturas. O termo fratura está sendo aqui empregado num sentido amplo, englobando descontinuidades de todos os tipos e de várias origens: juntas, diāclases, contatos, etc. En fim, estruturas que constituem elementos de descontinuidade no meio analisado e representam caminhos privilegiados de percolação d'àgua.

O meio fraturado se identifica, em geral, com os maciços ro chosos que poderiam ser descritos como constituidos por uma ma triz porosa (com maior frequência, a porosidade é de intersticios) cuja permeabilidade é desprezível, frente às altas permeabilidades das fraturas que cortam essa matriz. A permeabilidade global do meio corresponde à permeabilidade do conjunto de suas fraturas. Há 


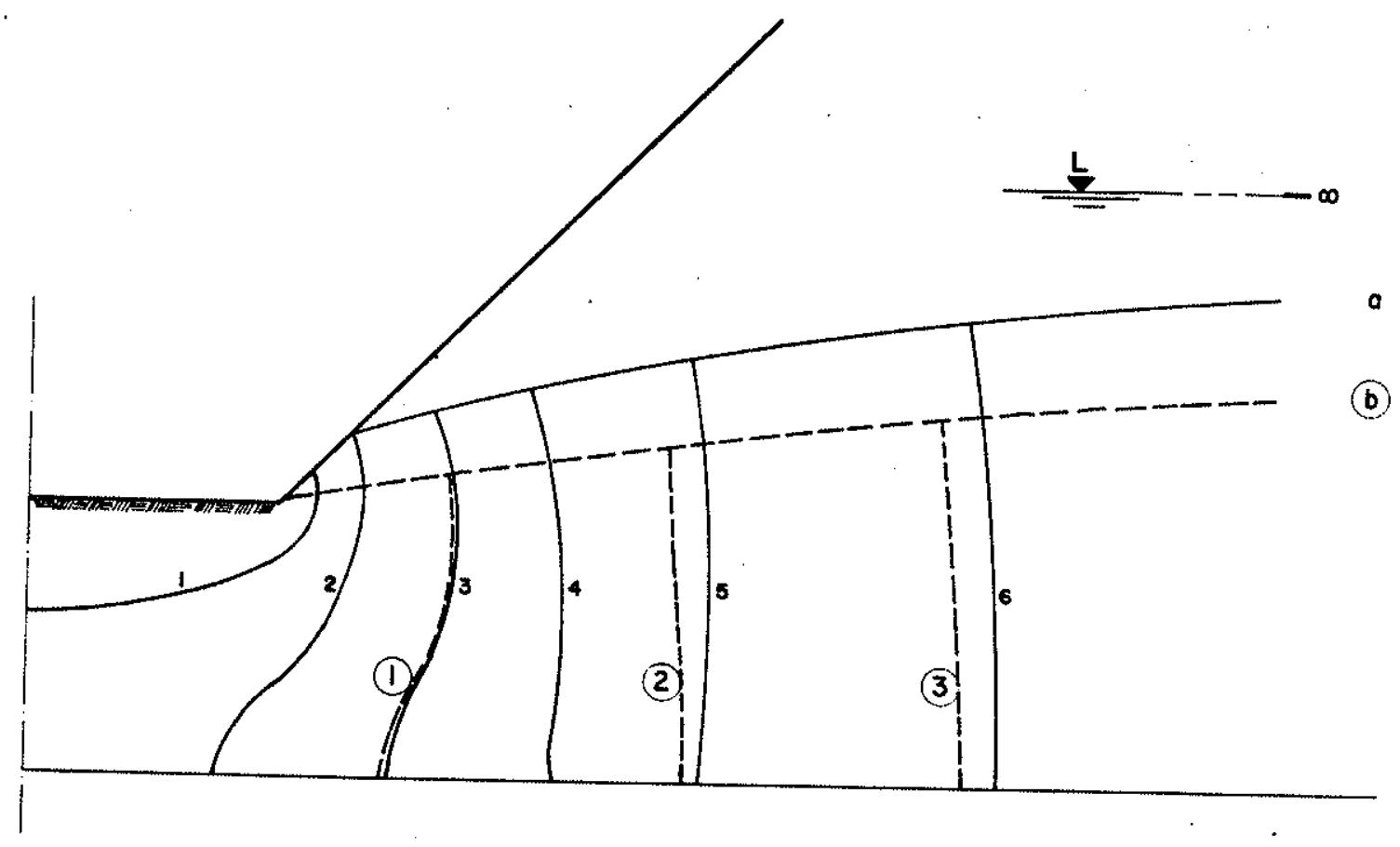

Figura 3 - Comparação entre os perfis de dois lençöis freáticos e suas respectivas equipotenciais, com uma mesma cota (L) a uma distância infinita do talude. Escoamento pa ra um talude côncavo (a) ou retilíneo (b). (DUFFAUT e LOUIS, 1972). 
exceções, como é o caso de arenitos cuja permeabilidade definida pela porosidade intergranular é ponderável no comportamento geral. Ou o caso de maciços rochosos cujas fraturas encontram-se preenchi das totalmente por material impermeāvel.

Os maciços rochosos são essencialmente heterogêneos, anisōtro pos e descontinuos. A complexidade que apresentam advém não só da variedade de gêneses diferentes, que promovem a constituição de ma trizes extremamente diversas, mas tambēm de sua história tectônica. Contudo, é a escala da porção do maciço analisado que define a vâ lidade de se considerar meio homogêneo ou heterogêneo, isótropo ou não e continuo ou descontỉnuo, no âmbito de um estudo qualquer.

A figura 4 procura, de maneira simples, ilustrar estes concei tos, tendo-se para tal considerado que o valor de permeabilidade de cada fratura unitāria é o mesmo para todas as representadas na figura. Assim, o caräter de heterogeneidade, anisotropia e descon tinuidade passa a depender apenas do grau de fraturamento no meio analisado e da orientação do sistema de fraturas, observados à luz da escala da obra ou fenômeno considerado. LOUIS (1974) considera que, quando - nümero de fraturas é muito reduzido, cada uma delas deve ser in dividualizada ao ser feita qualquer análise do problema. Segundo es te autor, o meio pode ser considerado continuo quando apresenta mais de 10.000 fraturas numa seção definida pelo tamanho da obra. Entre 100 e 1000 o meio deve ser considerado descontínuo. FRANCISS (1970) realizou uma série de ensaios eletro-analógicos para definir um critērio de seleção da escala do tratamento matemático ou analó gico adequado. De sua pesquisa resultou o seguinte critério (sendo e, o espaçamento médio entre as fraturas e $\mathrm{I}$ a dimensão do espaço analisado) $: e / L<0,1=0$ modelo pode ser assumido como contínuo; e/L $>0,1=$ há exigência de um tratamento do problema em modelo descontinuo. 

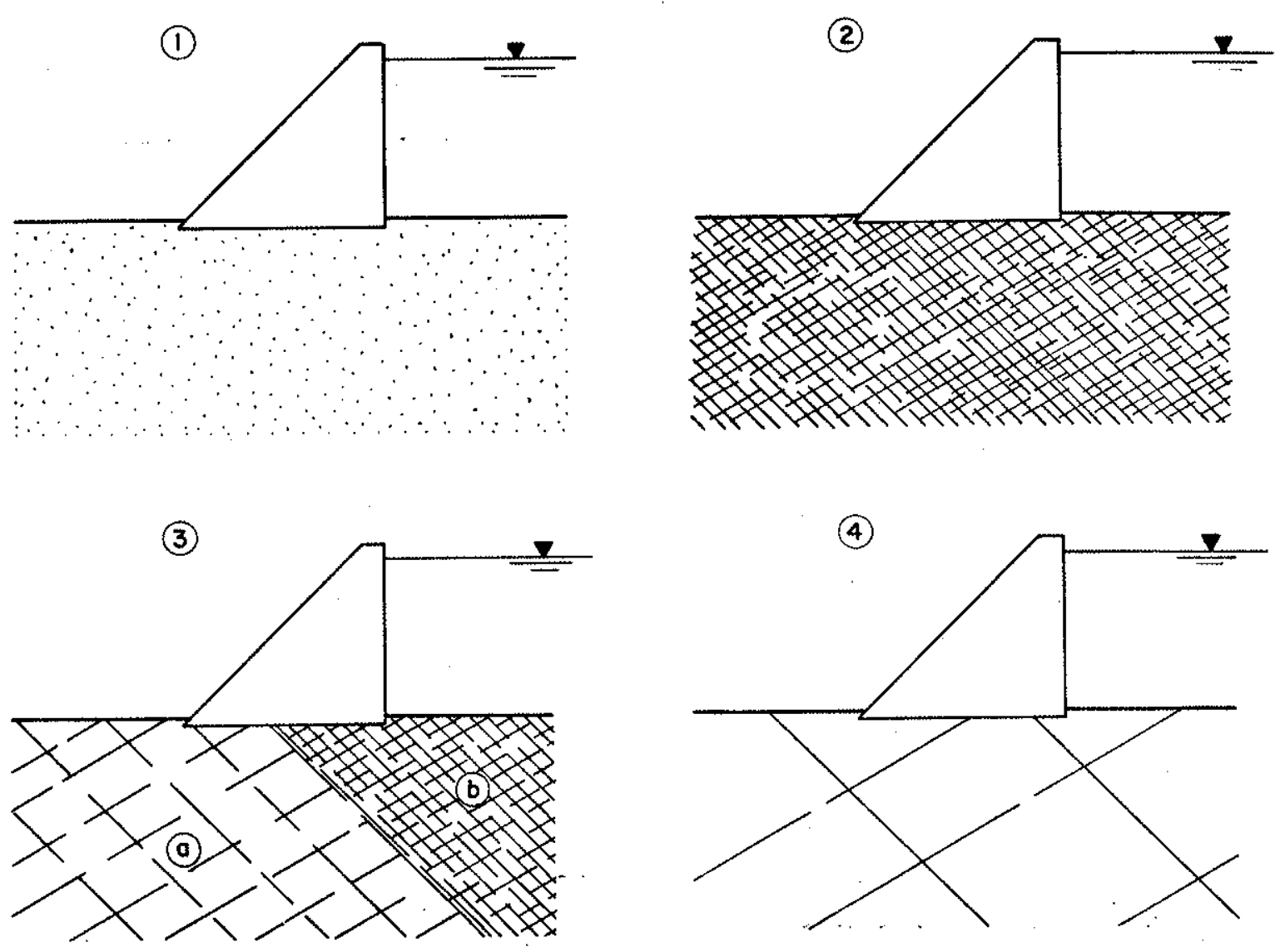

(1) e (2) meio homogêneo, isötropo e contínuo

(3) meio heterogêneo, sendo (a) anisōtropo e descontínuo e (b) isótropo e continuo

(4) meio homogêneo, anisótropo e descontinuo

Figura 4 - A questão da homogeneidade, isotropia e continuiciade resolvida na escala do problema considerado (liodificado de LOUIS, 1974). 
As fraturas se distribuem nas rochas e nos maciços rochosos desde a escala do grão mineral até extensões da ordem de quilôme tros. Várias propostas de classificação de fraturas colhidas por LOUIS (1974) são apresentadas na tabela 3 . Nesta tabela delimita-se o campo de anālise de interesse ao presente estudo que corres ponde aos maciços rochosos, nas escalas de uma barragem.

V.1. - Parâmetros hidräulicos do meio fraturado

Nos maciços com porosidade de fraturas, o elemento unitário básico è. a fratura. Os parâmetros hidrāulicos da fratura elementar têm sido analisados sobretudo em ensaios de laboratório, destacan do-se a abertura e a rugosidade como fundamentais no estudo das leis de escoamento (LOUIS, 1967).

o comportamento hidráulico do maciço é determinado pela combi nação dos comportamentos de cada sistema de fraturas. Na escala do maciço os parâmetros hidráulicos fundamentais são o espaçamento entre as fraturas (ou grau de fraturamento), a continuidade e a orientação de cada sistema.

V.2. - A permeabilidade ou a condutividade hidräulica dos meios Eraturados

Num sistema de fraturas (continuas) a permeabilidade (K) pode ser deduzida da permeabilidade das fraturas elementares (kf). Se gundo LOUIS (1974):

$k=\frac{e}{b} k f+k m$, onde

$\underline{e}=$ abertura média das fraturas;

$\underline{b}=$ espaçamento médio;

$\underline{\mathrm{km}}=$ permeabilidade da matriz rochosa

Nos maciços fraturados, $\mathrm{km}$ em geral é desprezivel em relação ao valor $\frac{e}{b} k f$. 


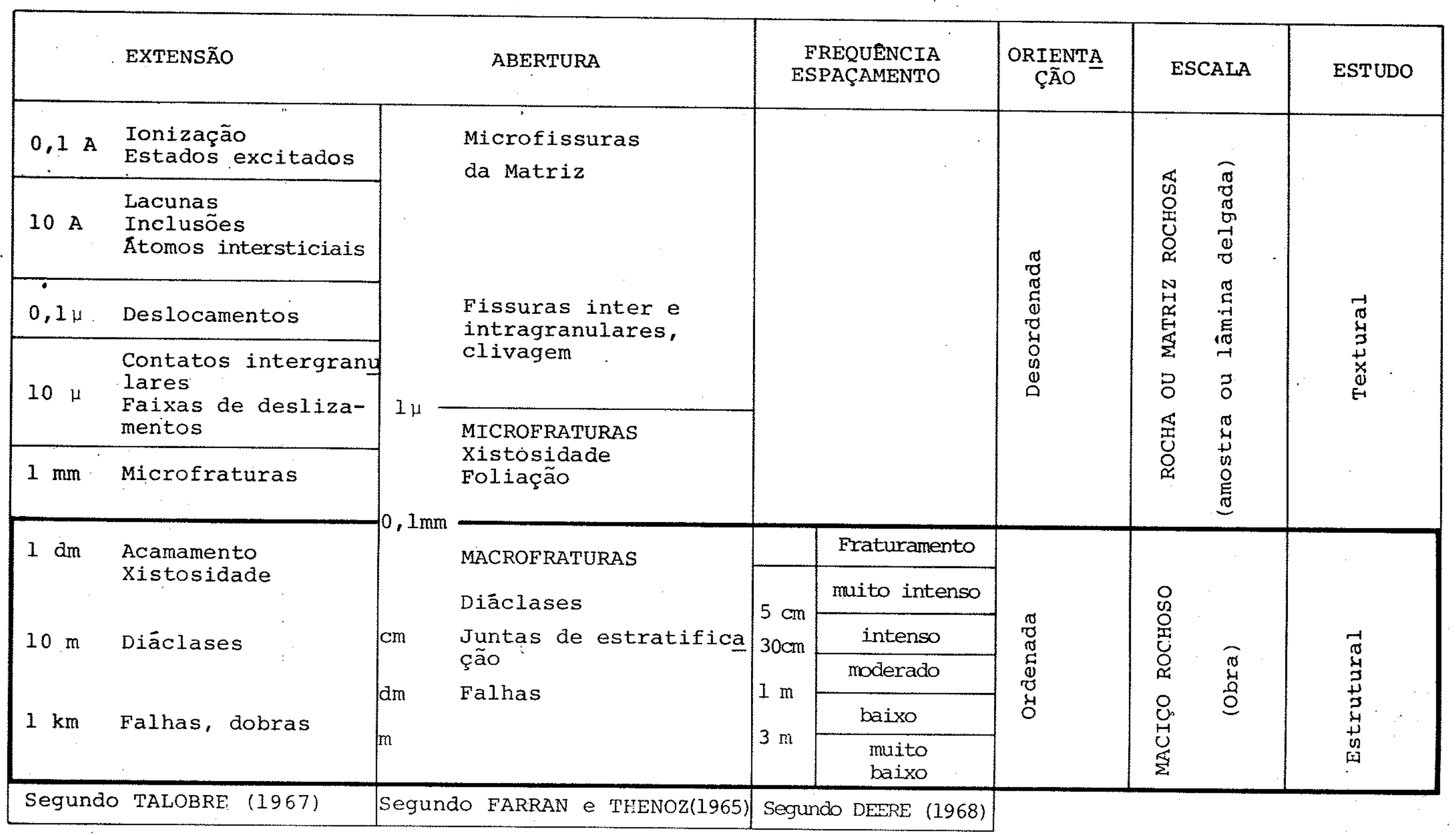

Tabela 3 - Tis descontinuidades nas rochas e maciços rochosos (iodiricacio de LouIs, 1974) 
Em regime laminar kf é definido por:

$k f=\frac{S g e^{2}}{12 v C} \quad$ (LOUIS, 1974), onde

$S$ = grau de separação da fratura (relação entre a superfície abe $\underline{x}$ ta e a superficie total da fratura);

$\mathrm{g}=$ aceleração da gravidade;

$\nu=$ viscosidade cinemática do fluỉdo;

$C=$ coeficiente que depende da rugosidade.

Notáveis progressos tem sido realizados nos estudos teóricos apoiados em ensaios de laboratório buscando-se determinar as leis de escoamento em fraturas onde se destacam a importância de parâ metros hidráulicos tais como a abertura e a rugosidade.

Tais estudos vem permitindo interpretar, em bases cientifi cas, os fenômenos hidrogeotécnicos observados. Como exemplo, pode-se citar os estudos realizados por QUADROS (1981)cujos resultados permitiram aprofundar a interpretação dos ensaios de perda d'ãgua sob pressão (veja item VII.2).

Por outro lado,os estudos das leis de escoamento vem possibi litando a resolução de problemas hidrogeotécnicos atravēs de mode los de anālise, matemáticos ou fỉsicos. (veja item VIII):

V.3. - Influência das tensões na permeabilidade dos maciços rocho sos

A importância da anälise das relações entre tensões e a per meabilidade dos maciços rochosos reside em dois aspectos princi pais:

1. - os maciços rochosos são sensíveis à ação de tensões cujos vâ lores são da ordem daqueles induzidos pelas grandes barragens. de concreto;

2. - as alterações provocadas por essas tensões se refletem signi 
ficativamente nos valores de permeabilidade e na sua distribuição nos maciços rochosos.

V.3.1. - Caracterỉsticas mecânicas dos maciços rochosos de interes se à Hidrogeotecnia

As rochas e os maciços são meios deformāveis. A deformabilidą de dos maciços ë bastante superior a das rochas, advindo tal. fato da presença de fraturas, sobre as quais agem preponderantemente as tensões. LOUIS (1974) propõe um modelo mecânico que traduz este comportamento e é ilustrado na figura 5 .

Por outro lado, as rochas e os maciços rochosos são muito mais sensiveis às tensões de tração que às de compressão, devido à presença de fraturas que praticamente não se opõem aos esforços que tendem a abrîllas. De uma maneira geral, a resistência à com pressão de uma rocha alcança valores de 10 a 30 vezes superiores a sua resistência à tração. No caso dos maciços rochosos, a resis tência a tração è em gexal, considerada desprezível nos projetos de engenharia civil (ROCHA, 1971).

Em termos de solicitações aos maciços rochosos pela implanta ção de obras civis, é importante considerar que as tensões assim induzidas nos maciços não se dissipam rapidamente em profindidade, como se poderia pensar aplicando-se a teoria da elasticidade de Boussinesq (TALOBRE, 1967), já que esta teoria assume os meios como homogêneos e contínuos. Os estu dos de KRSMANOVIC e MILIC (1963), realizados em modelo fotoelästi cos, mostram.que as tensões devem não só atingir profundidades muito maiores, mas, atravēs de sua concentra ção em porções do maciço, alcançar valores superiores às tensões originalmente aplicadas (figura 6 ). Os valores das tensões esua distribuição nos maciços rochosos dependem de uma série de fatores, entre os quais: a posição das fraturas em relação à direção dos 
-) fratura real

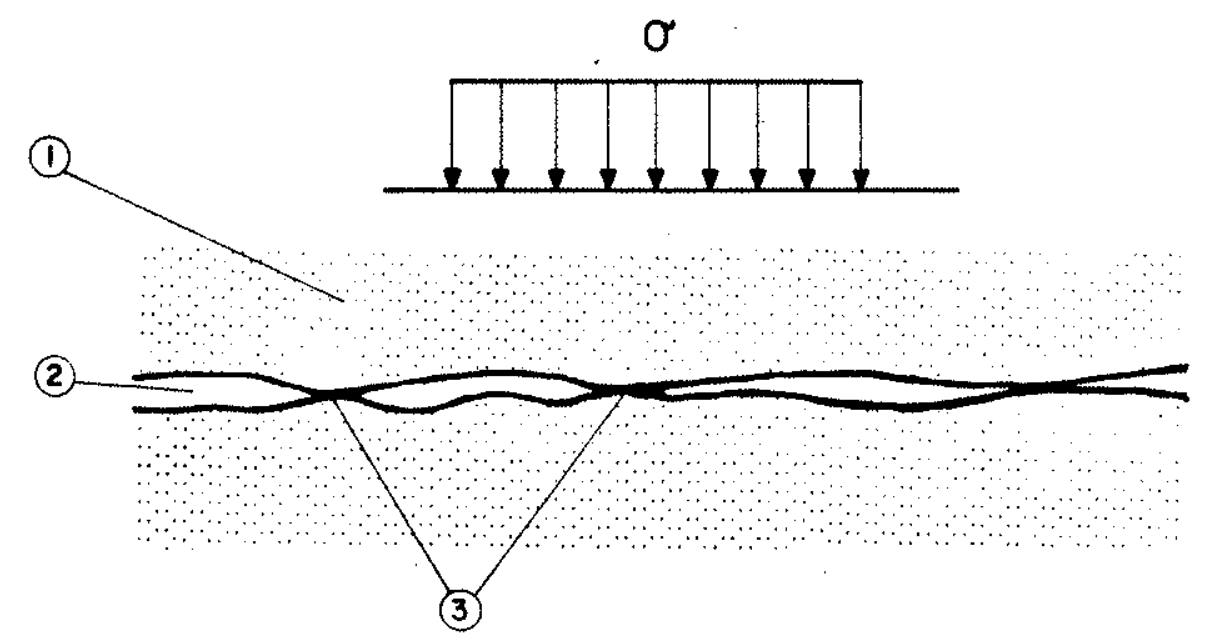

b) MODELL

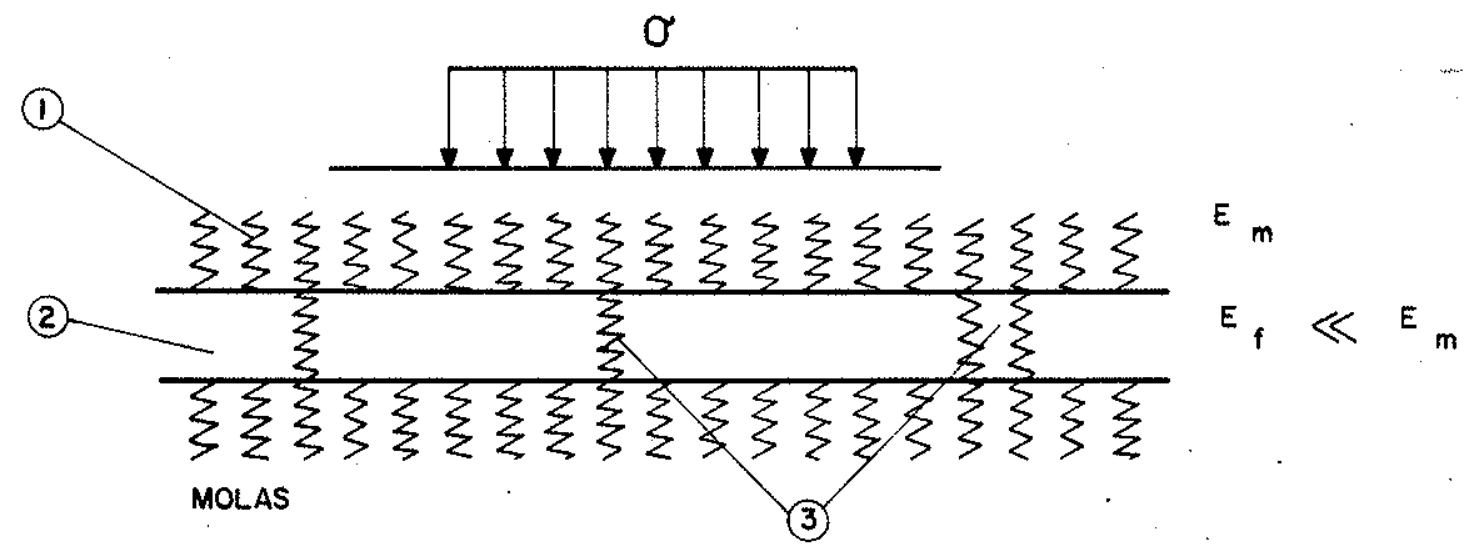

(1) Matriz rochosa de mōdulo de deformabilidade Em

(2) Fratura

(3) Contatos rochosos

Ef - Módulo de deformabilidade global do maciço fraturado

Figura 5 - Ilodelo mecânico que caracteriza o fenômeno de fechą mento das fraturas: (LOUIS, 1974). 


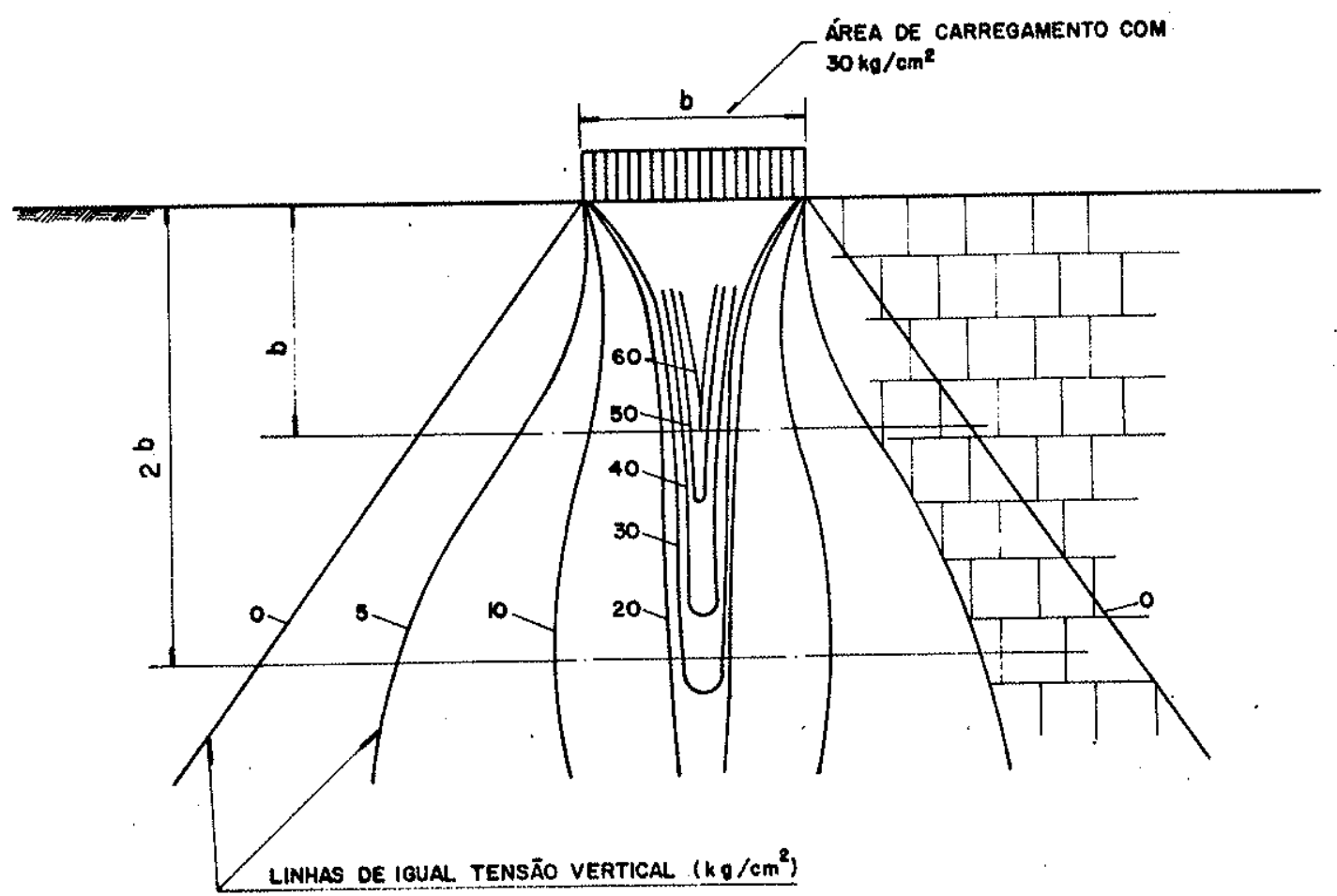

Figura 6 - Carregamento de un modelo biadimensional descontínuo (KRSIANOVIC e MILIC, 1963). 
esforços aplicados e o ângulo de atrito das fraturas (figura 7 ). V.3.2. - Relação das tensões com a permeabilidade

A relação das tensões com a permeabilidade respondem essen cialmente às alterações provocadas pelas tensões na geometria das fraturas. Dos parâmetros que são sensiveis às tensões ressalta-se a abertü ra das fraturas. Com efeito, a abertura é um dos parâmetros hidräu licos mais importantes que condicionam a permeabilidade dos maci Ços rochosos. Lomize e Louis (LOUIS, 1967) definiram leis de es coamento em fraturas onde a vazão varia com o cubo da abertura, desde que se considere fluxo laminar.

No modelo mecânico da figura 5 pode-se admitir a abertura ou fechamento da fissura atravēs de duas variações de tensões:

- ação de esforços externos que se concentram nos contatos rocha $x$ rocha;

- variação da pressão intersticial da água que percola a fissura. Com efeito o equilíbrio dos maciços é determinada pela lei ge ral da distribuição das tensões normais (LOUIS, 1974):

$\sigma_{t}=\sigma_{e}+U$, onde

$\sigma_{t}=$ tensão total;

$\sigma_{e}=$ tensão efetiva;

$\mathrm{U}=$ pressão intersticial da ãgua.

Pode-se assim analisar a relação das tensões com a permeabili dade atravës das variações de $\sigma_{e}$ (tensões impostas por uma barra gem por exemplo) ou de U (tensões impostas por um ensaio de perda d'água por exemplo).

a. - Alterações da pressão intersticial

LONDE e SABARLY (1966) evidenciam, a partir de um cálculo sim ples, a importância das tensões na abertura das fraturas e conse 

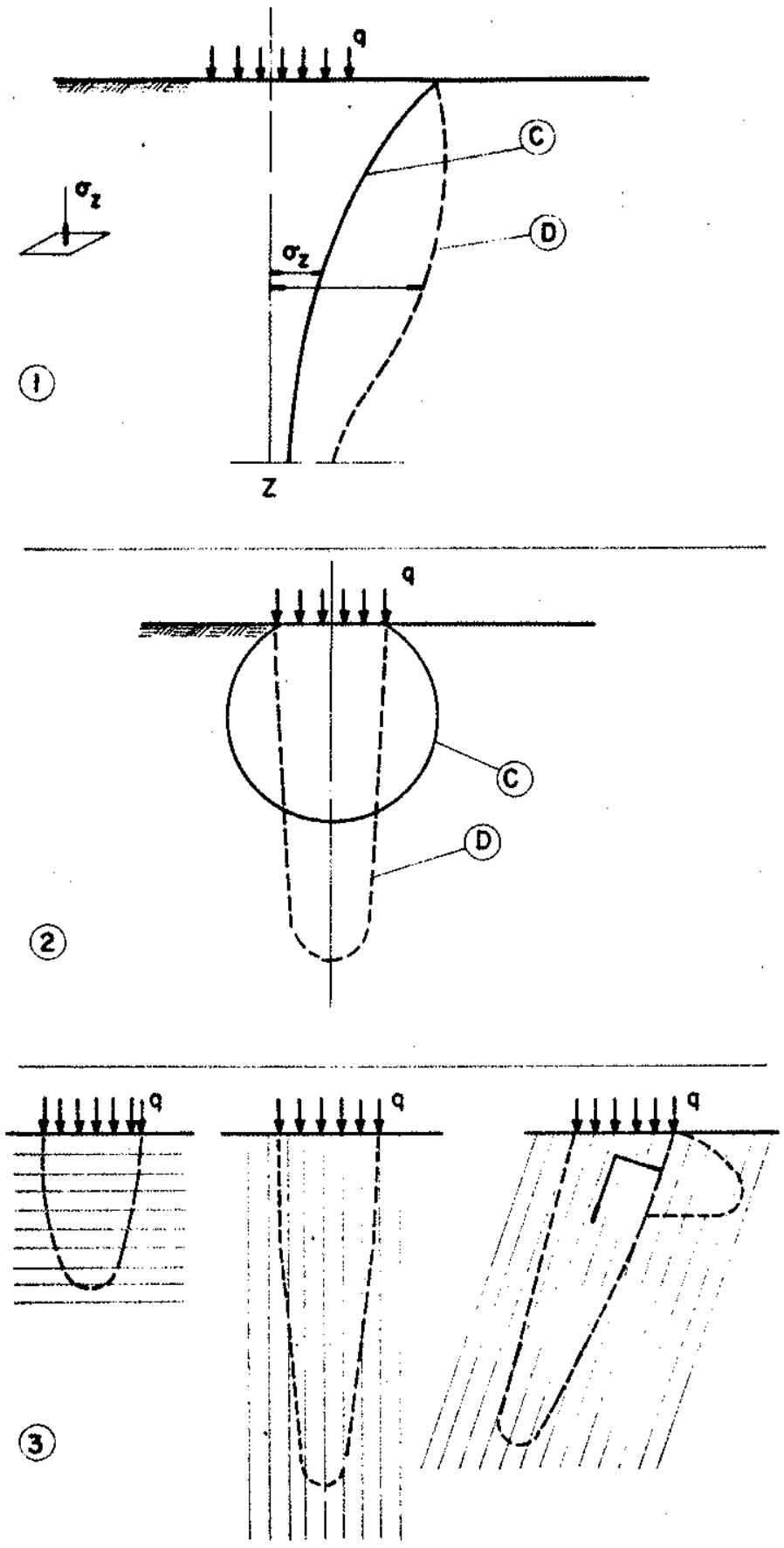

(1) Distribuição da tensão $\left(\sigma_{z}\right)$, ao longo do eixo, em função da profundidade (z)

(2) Bulbos de tensão

(3) Bulbos de tensão esquemáticos, em função da direção das fraturas

Figura 7 - Distribuição teórica de tensões em modelos continuos (C) e descontínuos (D) (LONDE E SABARLY, 1967). 
quentemente na permeabilidade do maciço.

Estes autores procuram inicialmente interpretar o ensaio de perda d'água sob pressão. Definem a vãzão $q$ através de uma fratu彑 ra (escoamento laminar e radial em fraturas lisas) pela expressão:

$$
q=B \cdot p \cdot e^{3} \quad(1), \text { sendo }
$$

$\underline{B}=$ uma constante que depende das propriedades do fluído e das con dições de contorno;

$p=a$ pressão;

$\underline{e}=$ a abertura da fratura.

o cálculo da abertura das fraturas ensaiadas segundo os resul tados obtidos (originalmente em unidades Lugeon) mostra as seguin tes relações:

\begin{tabular}{cccccc}
$\begin{array}{c}\text { Unidades } \\
\text { Lugeon } \\
(\mathrm{I} / \mathrm{min} / \mathrm{m} / 10 \\
\left.\mathrm{kg} / \mathrm{cm}^{2}\right)\end{array}$ & $\begin{array}{c}\text { Perda d'ägua } \\
\text { especifica } \\
(\mathrm{L} / \mathrm{min} / \mathrm{m} / \mathrm{kg} / \\
\left.\mathrm{cm}^{2}\right)\end{array}$ & $\begin{array}{c}\text { Permeabilidade } \\
\text { aproximada } \\
(\mathrm{cm} / \mathrm{s})\end{array}$ & \multicolumn{2}{c}{$\begin{array}{c}\text { Abertura aproximada de cada } \\
\text { fratura (mm) }\end{array}$} \\
1 & 0,1 & $10^{-5}$ & 0,10 & 0,05 & 0,02 \\
10 & 1,0 & $10^{-4}$ & 0,20 & 0,10 & 0,04 \\
100 & 10,0 & $10^{-3}$ & 0,50 & 0,25 & 0,10
\end{tabular}

O quadro mostra que mesmo fraturas muito finas podem apresen tar uma alta vazão. Em seguida,os autores consideram os efeitos da pressão d'ägua injetada na abertura da fratura, supondo que a pres são $p$ é aplicada uniformemente num pequeno círculo (de raio $\underline{r}$ ), con cêntrico ao furo da sondagem:

$$
\Delta e=\frac{4\left(1-v^{2}\right)}{E} \operatorname{pr} \quad(2) \text {, onde }
$$

$\underline{\nu}=$ coeficiente de Poisson;

$\underline{E}=$ coeficiente de elasticidade.

Para se obter uma ordem de grandeza do efeito, admitem: $E=200.000 \mathrm{~kg} / \mathrm{cm}^{2}$ 
$\underline{\nu}=0,5$

$\underline{\mathrm{r}}=2 \mathrm{~m}$

$\underline{D}=10 \mathrm{~kg} / \mathrm{cm}^{2}$

o cálculo apresenta um resultado de $\Delta \mathrm{e}=0,3 \mathrm{~mm}$. Concluem os autores que o efeito da abertura das fraturas pela pressão d'āgua injetada pode conduzir a altos valores de permeabilidade num maci ço em que as fraturas estavam de início fechadas ou eram extrema mente finas.

Relacionando as fórmulas (1) e (2), se a abertura inicial da fratura è muito pequena:

$$
q=\mathrm{Cp}^{4}(3) \text {, onde }
$$

$\underline{C}$ è um coeficiente que depende da natureza da rocha e do diâmetro do furo. Esta relação mostra a grande influência que a pressão $\underline{p}$ exerce sobre a vazão, em especial em todos os maciços rochosos pou co permeāveis (fraturas finas). Esta conclusão foi corroborada por BERNAIX (1967) atravēs de uma sērie de ensaios de laboratörios, que serão vistos a seguir (item V.3.3.).

\section{b. - Alterações da tensão efetiva}

Os mesmos autores, LONDE e SABARLY (1966), exemplificam de forma simples, os efeitos das tensões efetivas na permeabilidade Admitem uma tensão o orientada segundo um ângulo $\underline{\alpha}$ em relação ao plano das fraturas, de abertura e e espaçadas entre si de $\underline{b}$ :

$$
\frac{\Delta e}{e}=-\sigma\left(\frac{1}{E g}-\frac{1}{E m}\right) \frac{b}{e} \operatorname{sen} \alpha \text {, onde }
$$

$\underline{E_{g}}$ é o coeficiente da deformabilidade global do maciço e $\underline{\mathrm{Em}}$ o da matriz rochosa. Considerando $\mathrm{Em}$ muito grande $\left(500.000 \mathrm{~kg} / \mathrm{cm}^{2}\right.$ por exemplo) propoẽm uma primeira aproximação:

$$
\Delta e=-\frac{\sigma \operatorname{sen} \alpha}{E g / b}
$$


Para se ter uma ordem de valor de $\Delta e$ supõem:

$\mathrm{Eg}=50.000 \mathrm{~kg} / \mathrm{cm}^{2}$

$\mathrm{b}=1 \mathrm{~m}$

$\sigma=50 \mathrm{~kg} / \mathrm{cm}^{2}$ (em compressão)

$\alpha=30^{\circ}(\operatorname{sen} \alpha=0,5)$

Assim, $\Delta e=-0,5 \mathrm{~mm}$

Este resultado significa que toda fratura com menos de $0,5 \mathrm{~mm}$ de abertura e com orientação superior a $30^{\circ}$ sob uma tensão de $50 \mathrm{~kg} / \mathrm{cm}^{2}$, seria completamente fechada. Por conseqthência teria uma permeabili dade teoricamente nula. Se as tensões fossem de tração o fenômeno seria inverso: as fraturas teriam tendência a se abrir. Nos maci ços rochosos, por apresentarem uma baixa resistência à tração, é provável que o fenômeno se produza com maior intensidade.

o cálculo simples de LONDE e SABARLY (1966) deve ser conside rado tão somente como uma tentativa de se determinar algumas ox dens de valor dos parâmetros envolvidos no fenōmeno. Não há nenhum estudo teórico que possa prever o comportamento real da permeabili dade de maciços rochosos quando estes são submetidos a tensões. As limitações se devem sobretudo à dificuldade em se medir a abertu ra das fraturas tal como ocorrem na natureza. LOUl:s (1974) exempli fica estas limitações com o problema da determinação da continuida de ou descontinuidade das fraturas em seus planos de ocorrência. 0 autor considera 3 tipos de fraturas (figura 8), segundo a escala de fenômeno considerado:

- Caso al: fraturas abertas e continuas.

- Caso b: fraturas abertas e continuas no seu plano, porém inter rompidas em vários pontos, por contatos rocha $x$ rocha de exten são limitada. A àgua em escoamento contorna tais contatos.

- Caso c: fraturas abertas porém descontinuas no seu plano. 0 es 
- fraturas contínuas
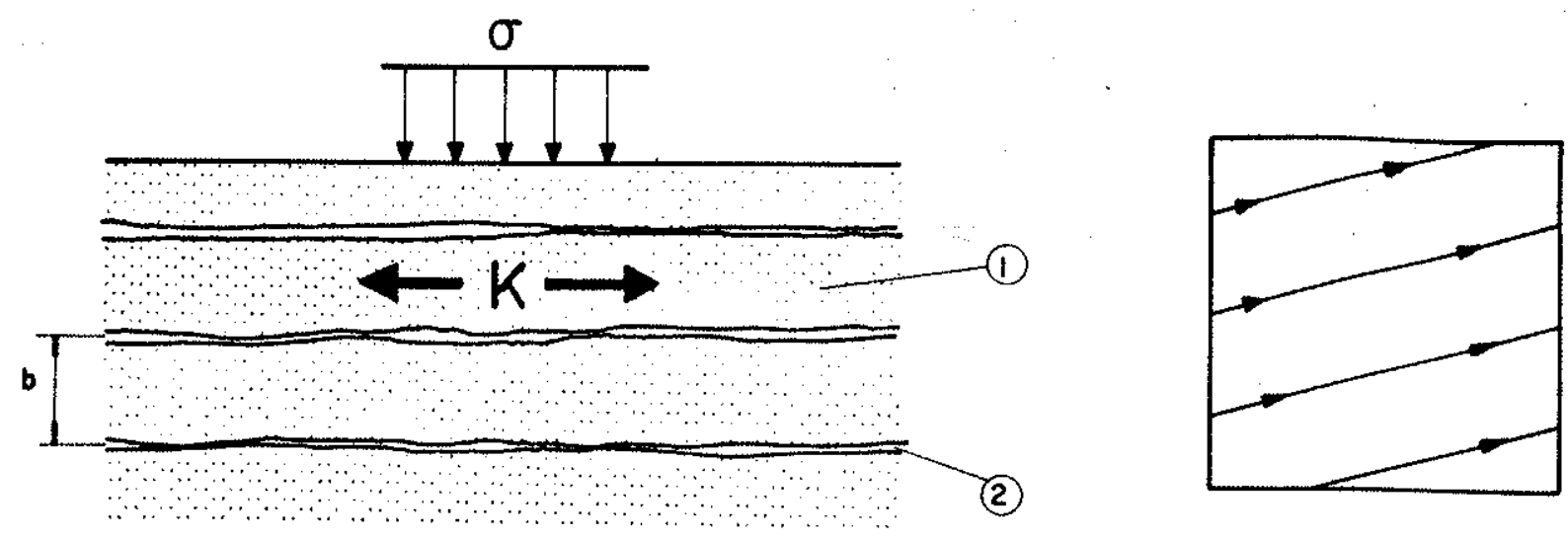

b) FRATURAS CONTÍNUAS COM CONTATOS ROCHOSOS ISOLADOS

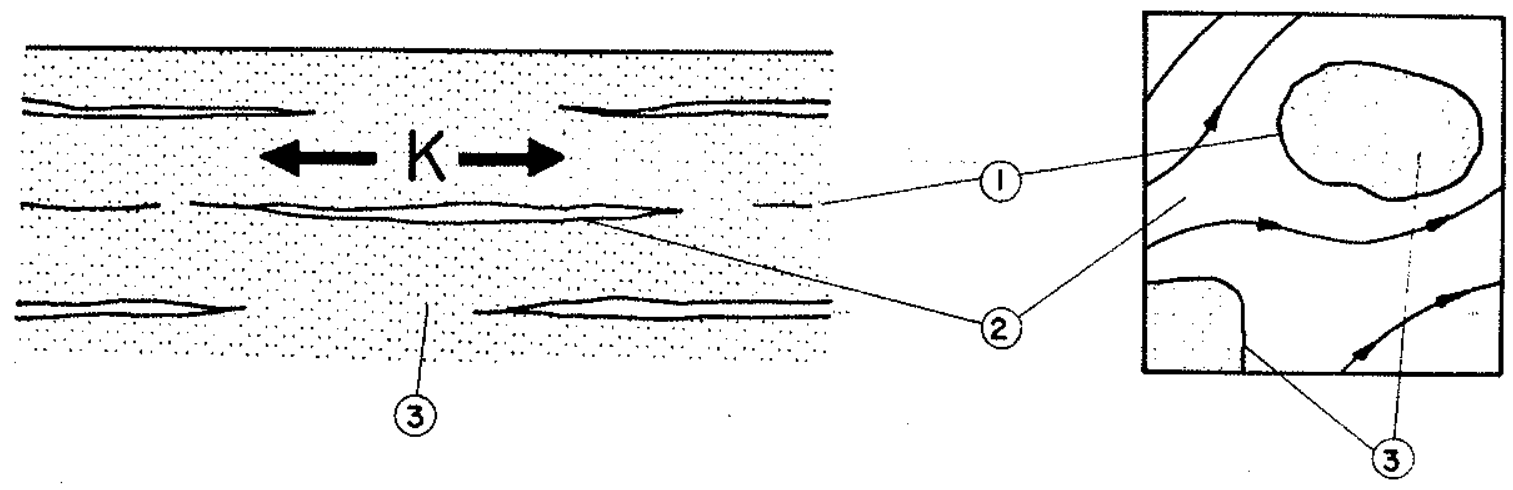

c) FRATURAS DESCONTÍNUAS ISOLADAS

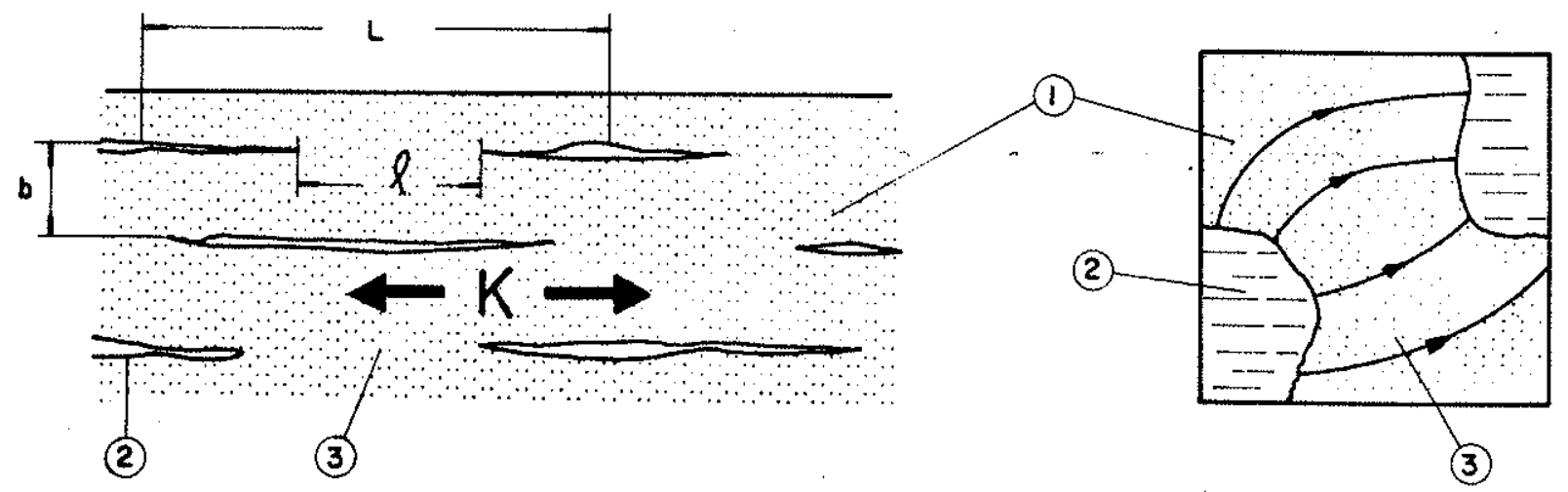

(1) Matriz rochosa

(3) Contatos rochosos
(2) Fraturas abertas

$\mathrm{K}$ - Condutividade hidráulica do sistema de fraturas

Figura 8 - Esquema do fraturamento dos maciços rochosos (Lours, 1974). 
coamento se faz essencialmente atravēs da matriz rochosa ou fra turas secundārias.

Considera o autor que nos casos a e $\underline{b}$ a permeabilidade do meio, paralelamente às fraturas, depende da abertura das mesmas através de uma lei com $e^{3}$ em regime laminar e com $e^{2} \mathrm{em}$ regime turbulento. Nestas condições, uma variação da tensão nor mal (em compressão) provoca uma variação importante da permeabi lidade. No caso $\subseteq$ a permeabilidade è independente da abertura das fraturas, não dependendo senão de sua freqtência. Um esforço de compressão normal provocará sempre um fechamento das fraturas prin. cipais, mas este fechamento não alterarā a permeabilidade global. Se o meio não tem fraturas secundárias, a permeabilidade global so mente dependerä da permeabilidade da matriz. Assim, neste caso, a influência do estado de tensões sobre os escoamentos será extrema mente atenuada.

Dadas, portanto, as limitações de se efetuar o levantamento dos parâmetros que interessam à hidráulica, para se poder prever a sensibilidade do comportamento hidráulico das rochas e dos maci ços fraturados, frente às tensões, vārios autores se voltaram para a realização de ensaios de laboratório e "in situ" além da auscul tação hidráulica de fundações de barragens para melhor compreender - fenômeno. WITTKE (1973), relator geral do simpósio sobre "Percola ção através de rochas fraturadas", de stuttgart, conclui que nenhu ma lei geral pode ser formulada e consequentemente, nos casos prā ticos, dados importantes somente podem ser obtidos de investigações experimentais adequadas.

\section{V.3.3: - Ensaios de laboratório}

Um dos principais tipos de ensaios de laboratório, que tradu zem a relação das tensões com a permeabilidade, foi desenvolvido 
por BERNAIX (1967). Os resultados obtidos pelo autor permitiram es clarecer o fenômeno preponderante como condicionante da ruptura das fundações de Malpasset.

Os ensaios são realizados em corpos cilindricos de rocha com um furo axial e submetidos a uma percolação centrifuga ou centrípe ta (figura 9). A diferença de pressão, entre o interior e o exte rior do cilindro, cria não só um gradiente hidrāulico que provoca um escoamento radial mas tambëm tensões na rocha. As curvas de per meabilidade traçadas em função das diferenças de pressão, interna e externa, traduzem a sensibilidade da rocha ao fenômeno. Esta sen sibilidade è tanto maior quanto maior for a intensidade do fratura mento. O indice $s$, definido pelo autor, como sendo a relação entre as permeabilidades a $-1 \mathrm{~kg} / \mathrm{cm}^{2}$ (tração) e a $+50 \mathrm{~kg} / \mathrm{cm}^{2}$ (compres são) reflete o grau de fraturamento da rocha. Se bem que estes en saios envolvam especificamente a matriz rochosa, os comportamentos obtidos podem ser comparados com o comportamento dos maciços na es cala de uma barragem. Por outro lado, estes ensaios refletem niti damente o quanto as rochas são pouco resistentes a esforços de tração, sobretudo quando intensamente fraturadas (curva $S=1000$ dả figura 9 ).

Podem ser tambëm citados os ensaios realizados por

LOUIS (1974) onde usou variações de tensões efetivas e não gradientes de pressões hidráulicas. As figuras 10 e 11 apresentam os resultados obtidos onde se verifica a alta sensibilidade das rochas fratura das às tensões, acusando uma lei exponencial de variação da per meabilidade em função dessas tensões. Os corpos fraturados apresen tam uma histerese importante nos ciclos de carga e descarga: Por outro lado, os meios porosos; sem fraturas aparentes, são pouco sensiveis às tensões. 


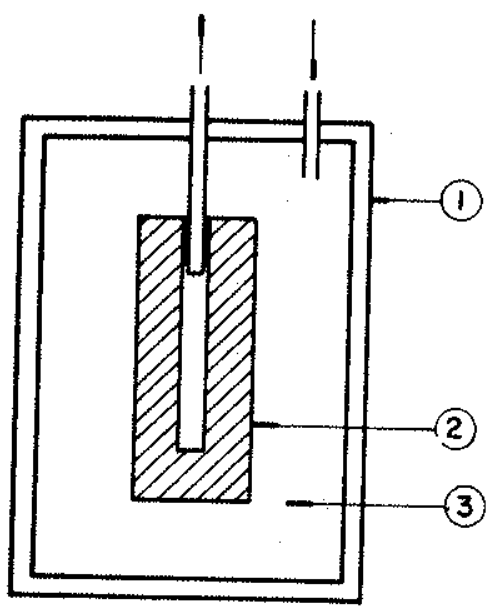

\section{(1) CĀMARA}

(2) CORPO DE PROVA ( $H=150 \mathrm{~mm}, \emptyset=60 \mathrm{~mm}$, FURO AXIAL DE $\varnothing=12 \mathrm{~mm}$ )

(3) ÁGUA SOB PRESSĀO $P$

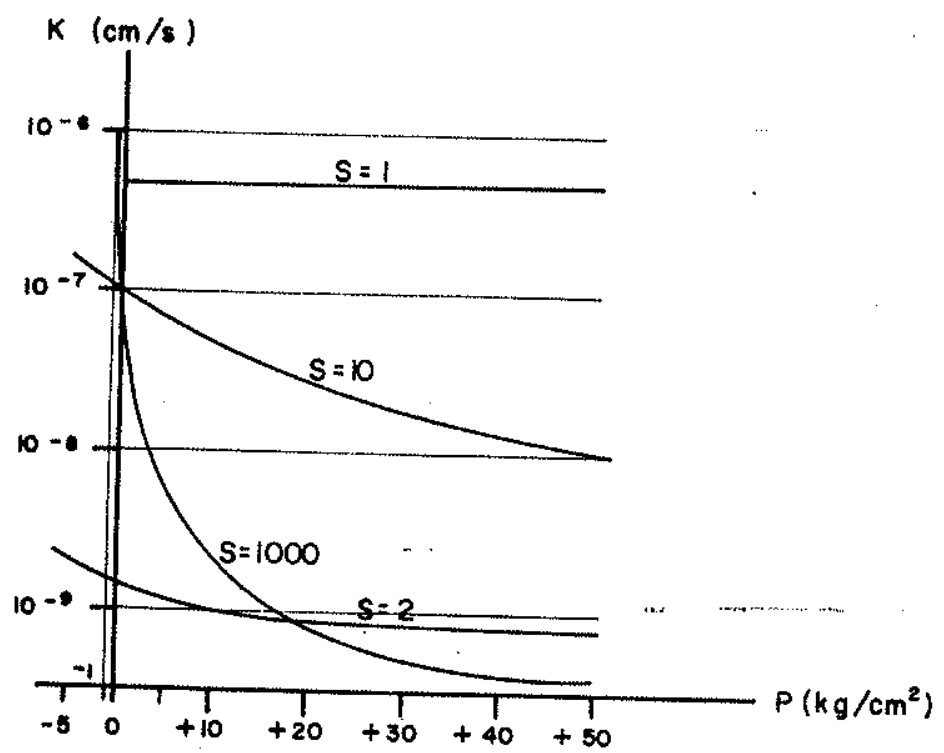

$$
S=\frac{K\left(-1 \mathrm{~kg} / \mathrm{cm}^{2}\right)}{K\left(+50 \mathrm{~kg} / \mathrm{cm}^{2}\right)}
$$

( $S=1)$ CALCÁRIO OOLITICO $(S=10)$ GNAISSE

$(S=2)$ GRANITO COMPACTO

$(S=1000)$ GNAISSE FRATURADO

Figuia 9 - Ensaios de percolação radial (BFRNAIX, 1967). 


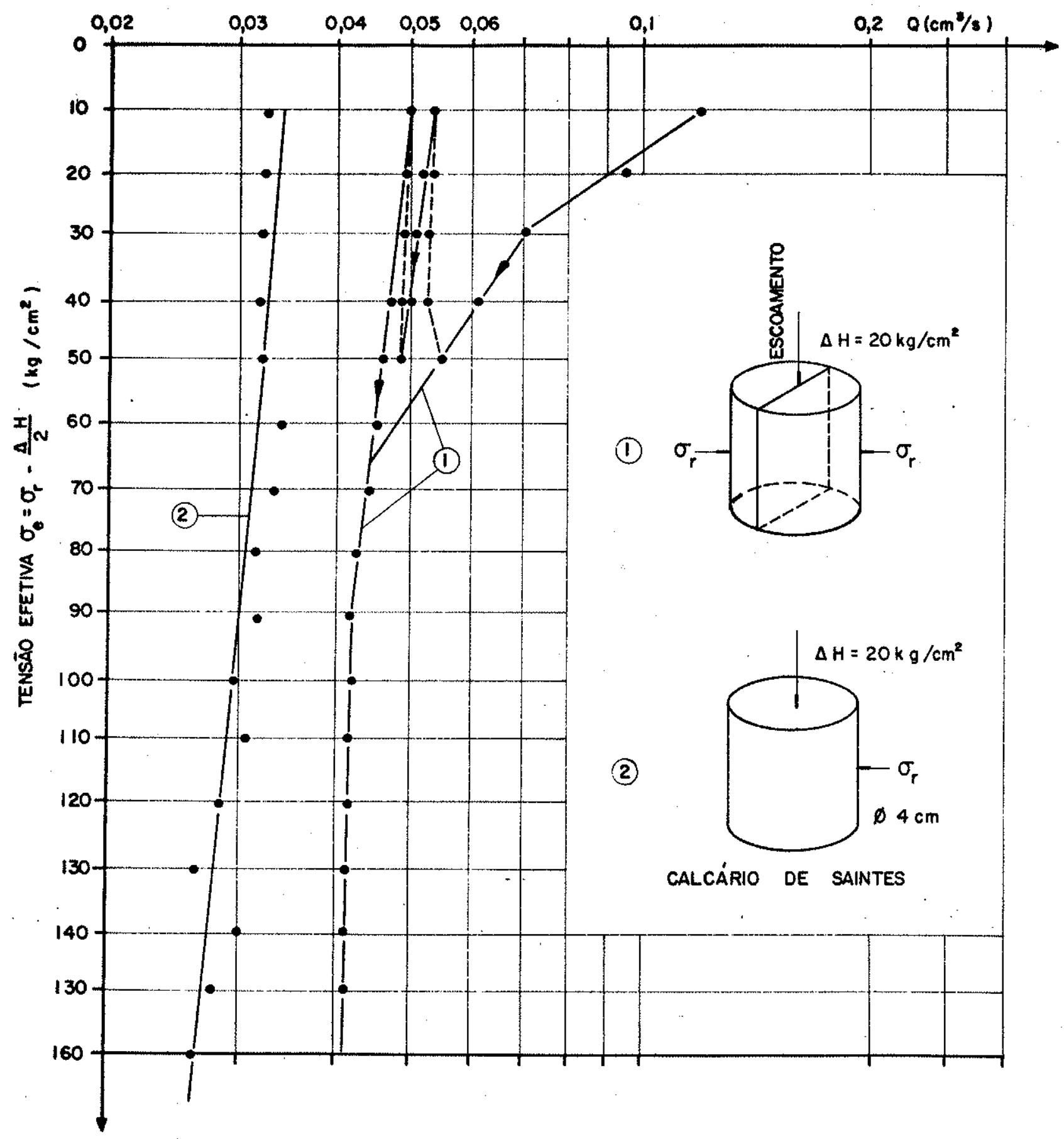

(1) Corpo de prova $(\phi=4 \mathrm{~cm}$ ) com fratura provocada por tração (2) Corpo de prova sem fratura

Figura 10 - Comportamento hidromecânico de um calcärio com ou sem fratura (LOUIS, 1974 ). 


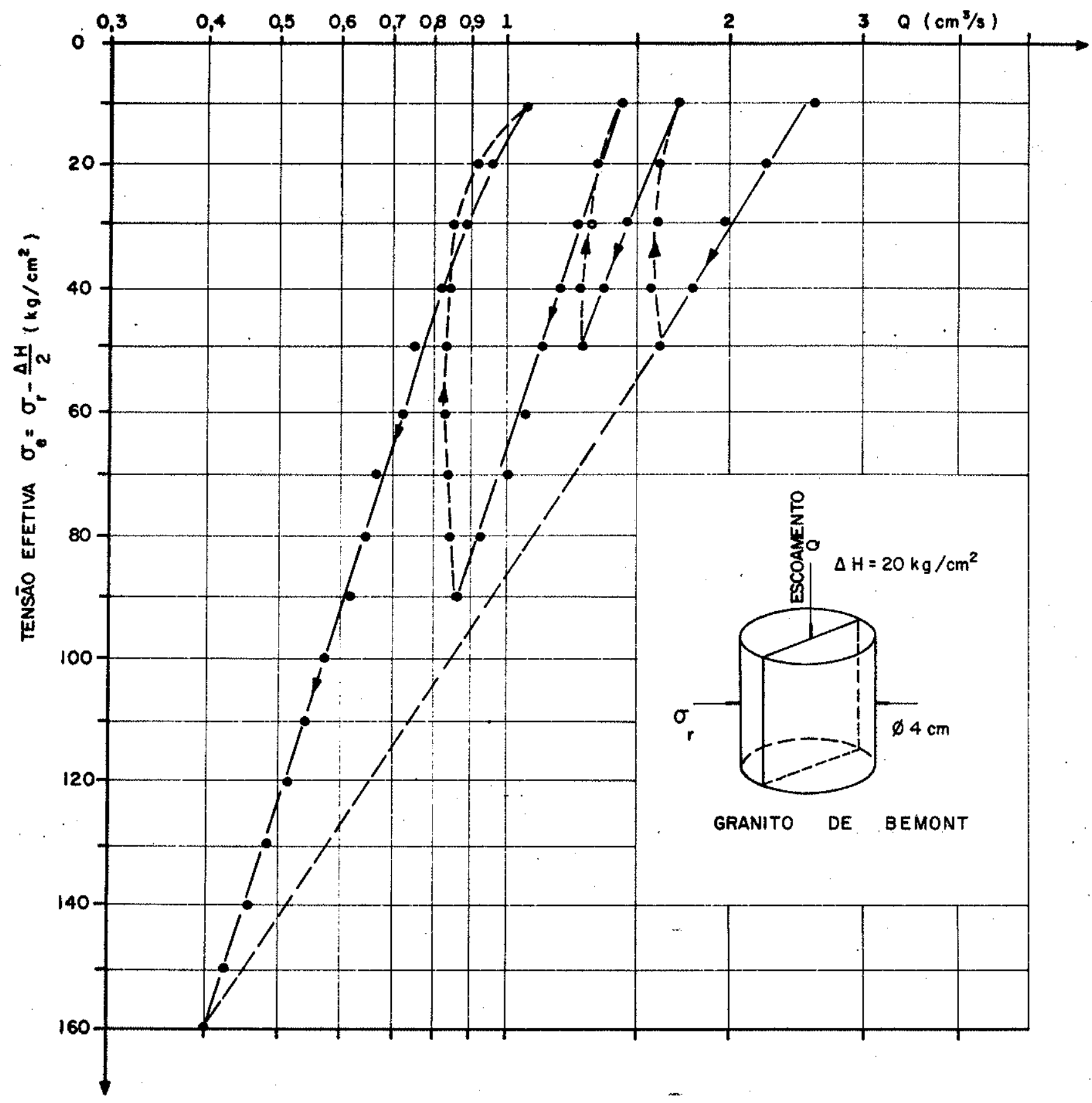

Figura 11 - Comportamento hidrodinâmico de uma fratura elementar (natural) do granito (LOUIS, 1974). 
v.3.4. - Ensaios "in situ"

Alëm dos ensaios de perda d'ägua sob pressão, outros ensaios, mais sofisticados, foram raramente executados. Pode ser citado o ensaio "in situ" realizado por JoUANNA (1973) que combinava um en saio de deformação de um maciço (micaxisto) com um ensaio de perda d'āgua sob pressão. Este ensaio revelou que com o aumento da ten são normal a permeabilidade diminui consideravalmente. No ensaio rea lizado o fenômeno foi irreversivel. As medidas de deslocamento vertical da rocha (deformação) corresponderam às mudanças da permeabilidade.

Por outro lado, ensaios de perda d'água sob pressão realizados a diversas profundidades dos maciços rochosos podem revelar a rela ção tensões $x$ permeabilidade. Assim como as argilas, que são extre mamente sensíveis à compressão e têm sua porosidade diminuỉa com a profundidade (item III.2), os maciços fraturados têm um compor tamento semelhante. Contudo, a variação da porosidade de fraturas com a profundidade estä relacionada, inversamente, com o alívio de tensões a que estiveram submetídos os maciços de gênese intrusiva. Maciços rochosos formados à superfície, como as rochas extrusivas, não devem apresentar uma relação semelhante. LoUIs (1972) a partir de ensaios de perda d'ägua e de förmula semelhánte à de Athy (item III.2) analisou a relação entre a permeabilidade e a profundidade em maciço gnäissico, durante investigações para implantação da barragem de Grand Maison (França). Os efeitos do estado de tensões no maciço não atingem somente a permeabilidade mas tambēm uma sé rie de outras propriedades tais como o mödulo de deformação e a velocidade de propagação de ondas longitudinais. Enfim, pode-se es perar relações da profundidade com todas as propriedades dos mací ços rochosos que dependam essencialmente do estado de fraturamento do maciço (figura 12). Quanto à permeabilidade, em particular, al 
a) PERFIS HIDRÁULICOS,MECÃNICOS E SÍSMICOS

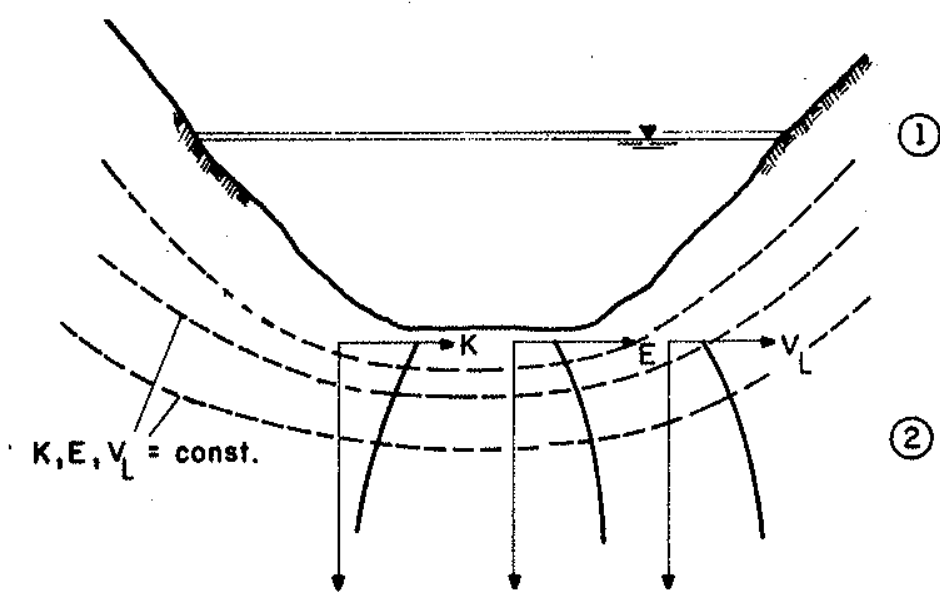

b) CURVAS CARACTERISTICAS DOS ENSAIOS DE PERDA D'AGUA
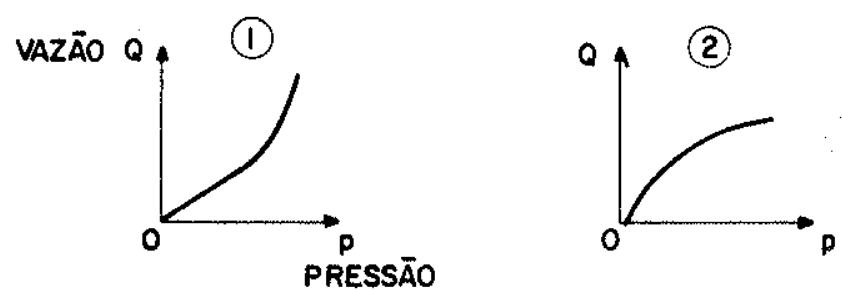

K - Condutividade hidräulica

E - Módulo de deformabilidade

$V_{L}$ - Velocidade longitudinal

(1) - Zona superficial do maciço rochoso

(2) - Zona profunda do maciço rochoso

Figura 12 - Reconhecimento hidrāulico, mecânico e geofísico de um local de barragem (LOUIS, 1974). 
guns resultados obtidos pelo autor são apresentados na figura 13. $\underline{A}$ través destes resultados o autor procurou definir o coeficiente $\alpha$ que depende da natureza da rocha e do fraturamento, na fórmula:

$$
K=K_{0} \cdot e^{-\alpha \sigma} \text {, onde }
$$

$\mathrm{K}_{\mathrm{O}}=$ permeabilidade, próximo à superfície;

$\sigma=$ tensão que pode ser estimada pelo peso do maciço (densidade $\gamma$ $x$ profundidade $t$ ).

Na figura 13, o caso examinado define o fator A que é igual a a $\gamma$. No local da barragem foram analisados vários ensaios cujos resultados permitiram definir a distribuição da permeabilidade em condições naturais (figura 14 ).

\section{VI. - AS SOIICITAÇÕES IMPOSTAS PELAS BARRAGENS}

Até agora analisamos as propriedades hidräulicas princïpais dos meios naturais, em particular dos maciços fissurados, visando compreender seus comportamentos mais importantes ao estudo hidro geotēcnico em barragens.

Os maciços rochosos, antes da construção das barragens, apre sentam um quadro dinâmico e essencialmente mutável em sua evolução geológica. Esta mutabilidade é provocada por vários tipos de ações dos quais pode-se ressaltar, como condicionantes fundamentais, as oscilações climáticas e as perturbações tectônicas. A ação da gra 


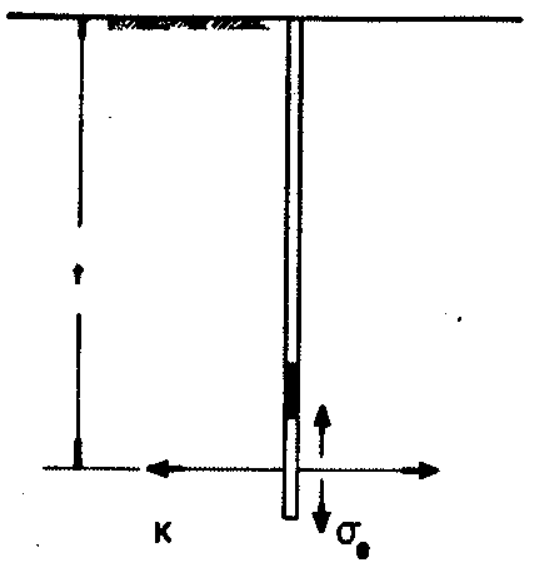

$$
\begin{aligned}
& k=k_{0} \cdot e^{-d \sigma} \\
& \sigma_{0}=\gamma^{+-p_{0}} \\
& \text { CASO DE SONDAGENS VERTICAIS }
\end{aligned}
$$

SONDAGEM 68.12

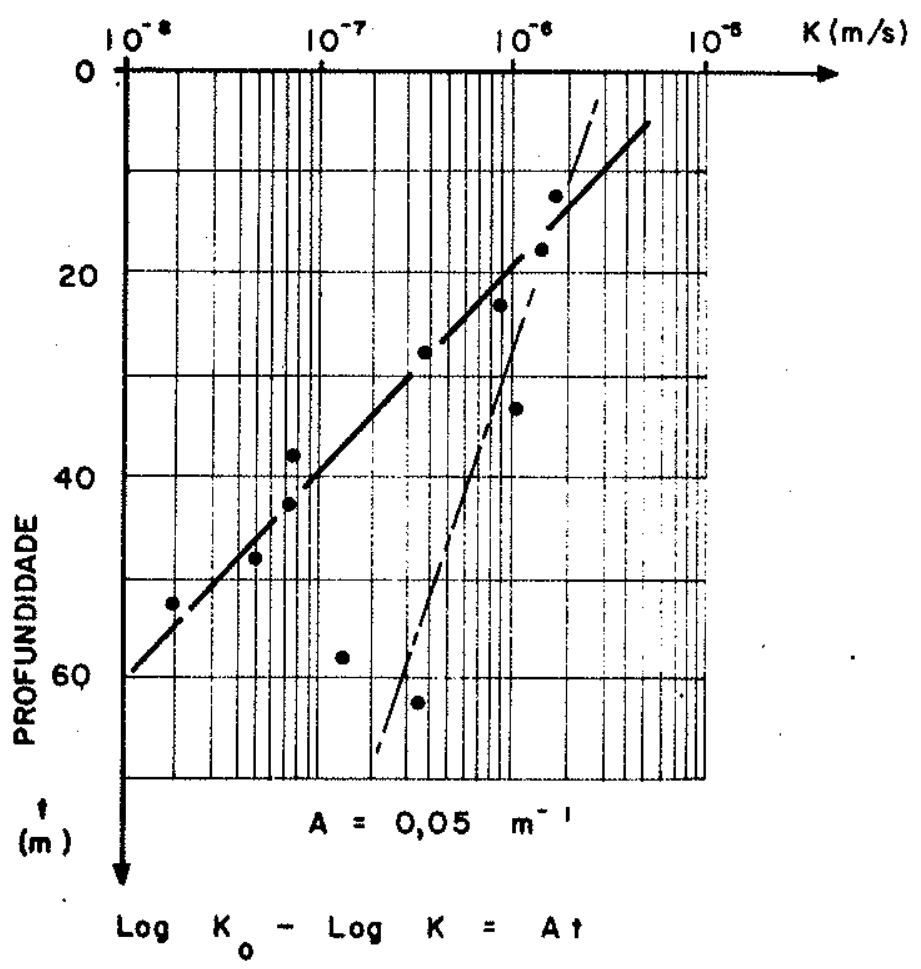

K - Condutividade hidrāulica perpendicular à son dagem

$\sigma_{e}$ - Tensão normal efetiva, perpendicular a $\mathrm{K}$

$\mathrm{P}_{\mathrm{o}}$ - Pressão intersticial média na zona do ensaio

Figura 13 - Variação da condutividade hidrăulica em função da profundidade no local da barragem de Grand Maison(LOUIS, 1974). 


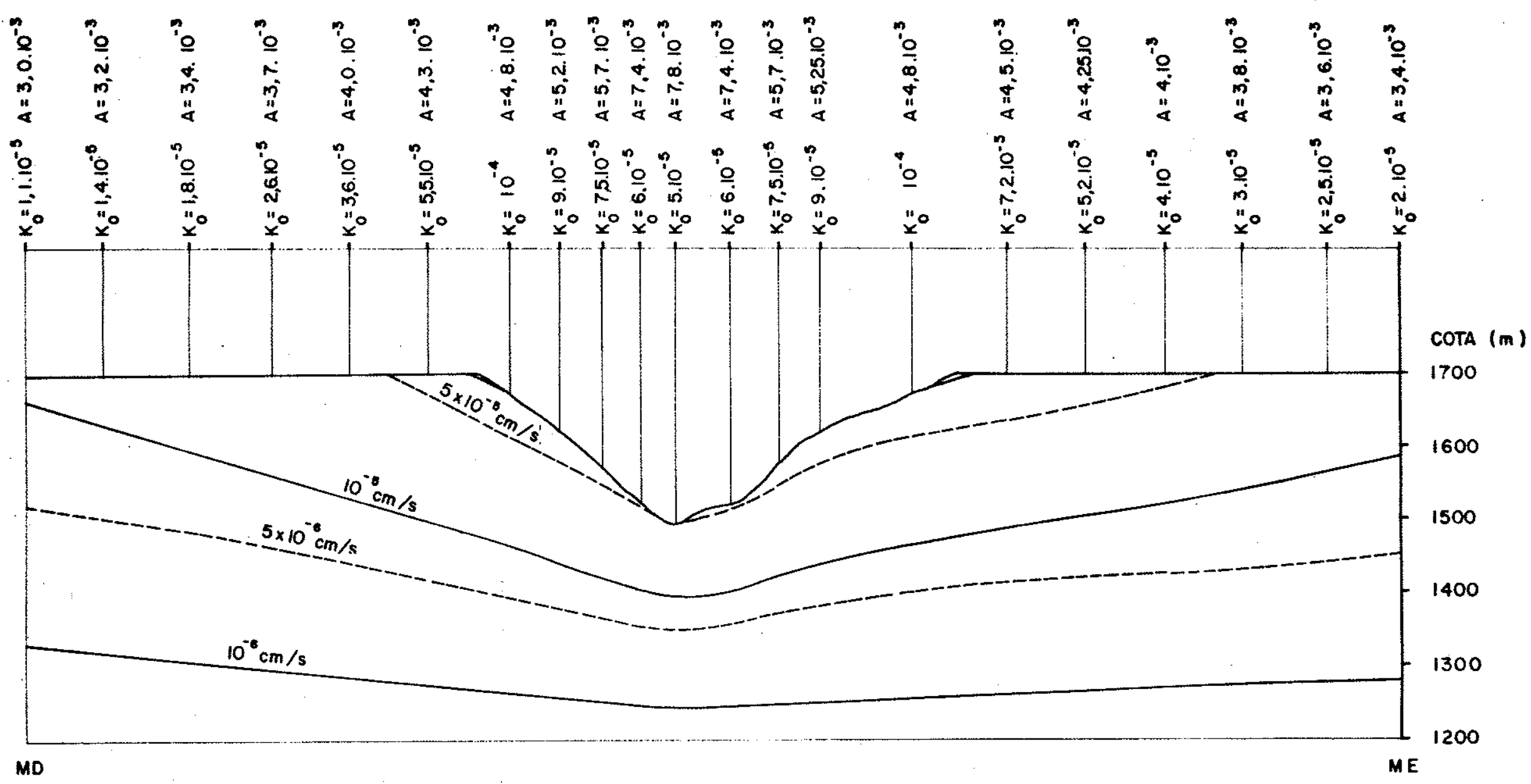

Figura 14 - Lei da distribuição do coeficience de permeabilidade nas condições naturais. Seção trans versal vertical $K=$ Ko $\operatorname{Lxp}(-A t),\left(K, \mathrm{~cm} / \mathrm{s} \in A, \mathrm{~m}^{-1}\right)$ (LOUIS, 1974). 
vidade, as tensões tectônicas, as ações mecânicas da āgua sujeitas aos gradientes naturais, as ações erosivas dos rios, os processos de intemperismo representam, entre outros, um conjunto de ações que, acima e abaixo da superficie do terreno, atua no meio físico se contrapondo ou se somando mas sempre num sentido definido da evolução geolögica. o continuo acúmulo de alterações provocadas por tais forças tendem a mudanças qualitativas importantes. Estas mudanças estão intimamente ligadas umas às outras, num complexo jogo de causas e efeitos, envolvendo vários fenômenos fỉsicos e químicos.

Assim, antes da construção da barragem, o maciço rochoso, este ve sujeito, atravēs dos tempos geológicos, a contínuas modificações que repercutiram na sua constituição mineralögica e estrutural. Com efeito, o maciço rochoso traz em si essa histōria, marcado por alterações e fraturamentos. Contudo seu estado atual permanece su jeito a essas modificações e podem ser ressaltadas suas principais tendências de evolução, principalmente pela compreensão dos even tos geológicos, e especialmente os geomorfológicos, mais recentes.

A construção de uma barragem constitui, neste quadro de evo lução natural do meio físico, um acontecimento drāstico. Vários processos naturais são bruscamente atenuados ou interrompidos lero são do leito do rio, por exemplo) e outros intensificados (instabi lização de encostas, por exemplo). A pröpria Geologia oferece modelos que reproduzem analogicamente a construção de uma barragem. O barramen to rápido de um curso d'ägua pode ser, por exemplo, provocado por um escorregamento importante das encostas. Tal evento provoca mudanças profundas na geomorfologia da região. O rio pode ter seu curso d'āgua desviado para áreas topograficamente menos elevadas ou extravasar, erodindo o barramento criado. Assim como as encos tas, os barramentos naturais e as barragens são essencialmente instäveis ao longo do tempo. 
A implantação de uma barragem desde suas fases iniciais de construção altera profundamente as condições geológicas dos maci ços naturais. Esţas alterações vão se somando e aumentando progres sivamente desde a execução de uma primeira ensecadeira até o enchí mento do reservatório. Os principais efeitos que podem ser identi ficados no meio físico pela construção, destacando-se aqueles rela tivos aos problemas de percolação d'ãgua, são em seguida, listados. Esta listagem não é limitativa e dá ênfase a aspectos da constrü ção de uma barragem de concreto em maciço rochoso. Por outro lado, não hã preocupação em se apontar relações de causa e efeito entre os fenômenos listados.

- Construção de ensecadeira e/ou desvio do rio

- alteração local do nível de base do rio

- alteração das forças erosivas do rio

- alteração dos gradientes de percolação d'ãgua nos maciços saturados

\section{- Escavação}

- rupturas do maciço (explosivos)

- alivio de tensões

- criação e abertura de fraturas

- aumento localizàdo da permeabilidade

- alteração de gradientes hidräulicos e no fluxo d'āgua

- queda das pressões hidrostáticas

- erosões internas ("piping")

\section{- Concretagem}

- carregamento do maciço e aumento de tensões

- fechamento de fraturas

- diminuição local da permeabilidade

- alteração dos gradientes hidrāulicos e no fluxo d'āgua

- aumento das pressões hidrostāticas 
- Enchimento do reservatörio

- inundação de maciços não saturados

- alteração do nível de base regional

- atenuação do processo erosivo do rio

- preponderância dos processos de sedimentação no lago formado

- empuxo da āgua na barragem e sua transmissão para as funda ções e apoios

- redistribuição de tensões

- aparecimento de tensões de tração e concentração de tensões de compressão

- criação, abertura e fechamento de fraturas

- rearranjo da permeabilidade do maciço de fundação e apoio da barragem

- aumento violento dos gradientes hidráulicos

- estabelecimento de novas direções de fluxo

- aumento das pressões hidrostāticas e de percolação

- erosões internas ("piping").

Ao contrário dos barramentos naturais ou encostas, as barra gens são construidas por materiais selecionados e dispostos de ma neira organizada, com dispositivos de vedação e drenagem, elementos de descarga de cheias, etc, de maneira a criar condições as mais favorāveis possiveis para sua estabilidade. Contudo, os maciços naturais permanecem como fundações ou apoios como ocorriam ante riormente na natureza. Não foram nem selecionados (exceto por oca sião dos estudos da escolha de eixos alternativos) nem organizados (exceto pela sua eliminação parcial nas escavações ou pelos trata mentos usuais de vedação e drenagem). Só que agora submetidos a condições mais arásticas de tensões e percolação d'água.

Tais considerações adquirem significativa importância ao se 
examinar a estatistica de causas de acidentes em barragens. Um le vantamento efetuado em 1764 barragens acidentadas, citado por MEILO (1966) apon tava $40 \%$ das causas como sendo de ordem geolögica e $20 \%$ de ordem hidrolögica (deficiência de vertedores). O autor, destacando estes dois tipos de causas como os principais no comportamento da natu reza, ressalta o primeiro, não só por ser responsāvel por um maior nümero de acidentes, mas por exigir o conhecimento da evolução geo lógica local e de seu estado de equilíbrio atual, sujejto à inter ferência humana.

Nos itens seguintes são analisadas as principais relações en tre o meio físico, tomando apenas no âmbito das fundações, e a bar ragem. Contudo, dada a amplitude do tema e retomando-se o campo de estudo da dissertação, restringe-se a anälise para os casos de bar ragens de concreto em maciços rochosos. Em relação às barragens de concreto serão tomados seus dois tipos principais de gravidade e ar co e, em relação aos maciços rochosos, consideram-se aqueles em que a porosidade de fraturas é preponderante.

\section{VI.1. - A percolação d'ägua e a estabilidade das barragens}

Em barragens do tipo graviidade o equilíbrio é limitado seja pela possibilidade de deslizamento sobre a fundação, seja por bas culamento em torno de seu pé de jusante. Num e noutro caso as con dições de equilíbrio são agravadas pela atuação das subpressões. A denominação subpressão foi dada por Levy em 1895 para explicar - acidente da barragem de Bouzey (MARY, 1965) :pressões hidrostäti cas que atuam de baixo para cima em planos determinados da estrutú ra da barragem (descontinuidades da concretagem, por exemplo) ou na superfície de contato concreto $\mathrm{x}$ rocha ou ainda em descontinuidades das fundações. Assim, alēm do empuxo d'aḡua do reservatório no paramen to de montante da barragem, o călculo da estrutura deve levar em 
conta as subpressões como esforços instabilizadoras. Contra elas a barragem do tipo gravidade contrapõe essencialmente o peso da es trutura, como o prōprio nome indica. O esboço a da figura 15 apre senta esquematicamente a disposição das forças em jogo.

Em barragens do tipo arco os empuxos da estrutura nas funda ções são de tal grandeza e as äreas passiveis de serem submetidas às subpressões sob a barragem são tão estreitas que è a zona imediatamente a jusante, livre dos empuxos da barragem, a mais delicada aos efeitos da percolação d'água. o esboço b da figu ra 15 apresenta esquematicamente esta situação.

VI.2. - Tensões induzidas nos maciços pelas barragens

As tensões induzidas nos maciços de fundação e apoio de barra gens resultam da aplicação das seguintes forças principais: peso da barragem e força resultante do empuxo d'āgua do reservatörio. Para uma mesma altura, as tensões induzidas por uma barragem arco são bastante superiores às de uma barragem do tipo gravidade. Isto se deve não só ao fato da laxgura da base da barragem arco ser muito menor, mas sobretudo devido ao efeito de arco,pröprio daquele ti po de barragem.

Contudo, as tensões induzidas nos maciços de apoio não depen dem exclusivamente destas forças mas das caracteristicas mecânicas desses maciços. De fato, os mētodos de cálculo das tensões levam necessariamente em conta a influência combinada da estrutura sobre as fundações e das fundações sobre as estruturas.

Assim, para se analisar as tensões induzidas nos maciços é importante relembrar algumas propriedades e comportamentos dos 

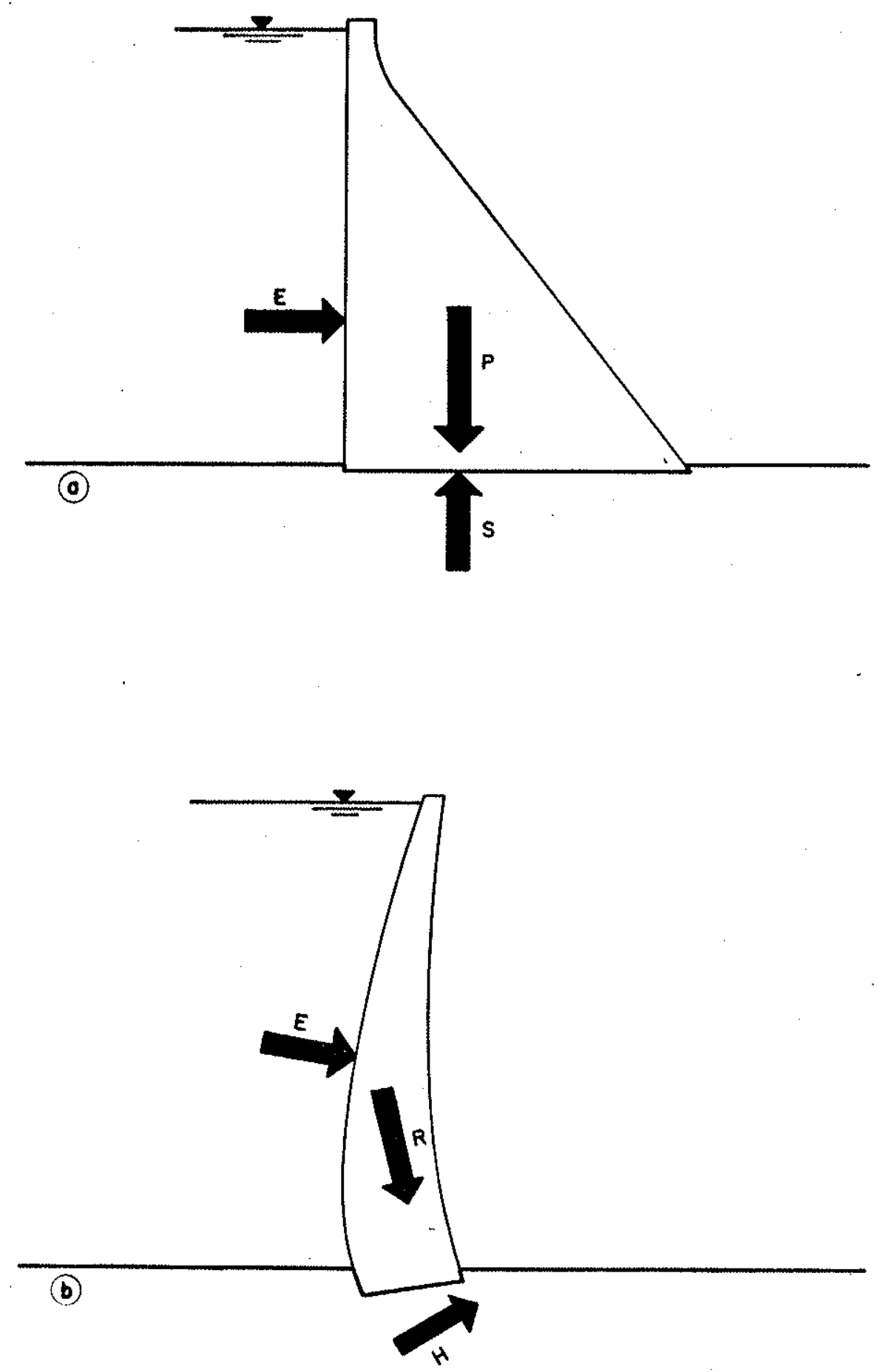

E - Empuxo d'āgua do reservatório

P - Peso da barragem

S - Subpressão

R - Empuxo da barragem arco

H - Força de escoamento ou ação hidrodinâmica da ăgua em escoamento

Figura 15 - Esquema dos principais esforços em jogo nas barragens do tipo gravidade (a) e arco (b). 
meios fraturados, anteriormente apresentados (item V.3):

a. - as propriedades e comportamentos dos meios descontínuos de pendem essencialmente das características das fraturas: sua orien tação, frequência, abertura, preenchimento, etc. Es tas caracteristicas dependem em última anālise da natureza da ro cha (gênese), de sua histōria tectônica e de sua evolução geomorfo lógica recente. Assim, são essencjalmente as fraturas que comandam e con dicionam todas as propriedades e comportamentos dos maciços rocho sos.

b. - ao contrário dos meios contínuos, os meios fraturados possibi litam a propagação das tensões a grandes profundidades além de permitirem altas concentrações de tensão.

c. - os meios fraturados têm baixa resistência à tração.

d. - os meios fraturados são extremamente sensiveis às tensões.

As considerações que se seguem foram de propōsito levadas a condições extremas de maneira a caracterizar de maneira clara o comportamento hidrogeotēcnico de maciços fraturados sob ação das solicitações das barragens. Tais condições, no entanto, podem efe tivamente ocorrer, sobretudo em maciços finamente fraturados, como demonstram os exemplos citados a seguir.

As tensões induzidas pelas barragens nos maciços de apoio pro vocam o aparecimento de zonas de tração e de compressão. Nas barra gens do tipo arco estas zonas são definidas pela posição do arco ativo que se prolona pelos apoios rochosos (VARLET, 1966). A montante, a zona de tração pode provocar o aparecimento de fraturas e a aber tura das pré-existentes permitindo uma intensa percolação d'ägua. Ao contrário, à jusante ocorre o fenômeno inverso, provocando o fechamento das fraturas. Tudo se passa como se o maciço adquirisse uma nova distribuição de permeabilidades, introduzindo heterogenei 
dades e anisotropias anteriormente inexistentes. A figura 16 apre senta esquematicamente a distribuição das zonas de tração e com pressão nas barragens do tipo arco. Contudo, em casos excepcionais, a zona de tração pode permitir o desenvolvimento de verdadeiras fra turas abertas ou fendas de tração. O fenômeno parece estar, sem dúvida alguma; entre as causas do rompimento das fundações de Malpasset. A foto da figura 17 mostra a existência de uma fenda na ombreira direita, e que pode ser seguida até a ombreira esquer da, paralelamente ao pé de montante da barragem.

Nas barragens do tipo gravidade o fenômeno também ocọrẹ po rém com intensidade bastante inferior. Com efeito, os cálculos de tensões demonstram esse fato. Contudo, algumas barragens adequadamente jns trumentadas, mostram um comportamento no minimo qualitativamente semelhante. Deve-se considerar que o aparecimento de tensões eleva das e das zonas de tração e compressão com maior ou menor contras te não depende exclusivamente das forças aplicadas mas das caracte risticas de fraturamento do maciço de apoio. Assim é que, mesmo em casos em que se tem constatado uma certa inclinação de barragens de gravidade para montante, devido condições geológicas particulares e au peso da água do reservatório, verificou-se o aparecimento de fissuras na zona de montante. E o caso da barragem de Bratsk na URSS (TIZDEL, 1970).

são evidentes os efeitos que tais tensões induzem no escoạ mento d'água pelas fraturas. A abertura das fraturas na zona de tração de montante provoca um incremento localizado da permeabili dade original do maciço. Ao contrārio, à jusante, na zona de com pressão, o seu fechamento provoca uma redução daquela permeabili dade. o contraste de permeabilidades assim criado condiciona escoamento da āgua: abrindo fraturas e portanto "drenando" a montan te e fechando-as, portanto "vedando-as" a jusante. Criadas estas condições, o fluxo da āgua se faz de tal forma que desenvolve pres 


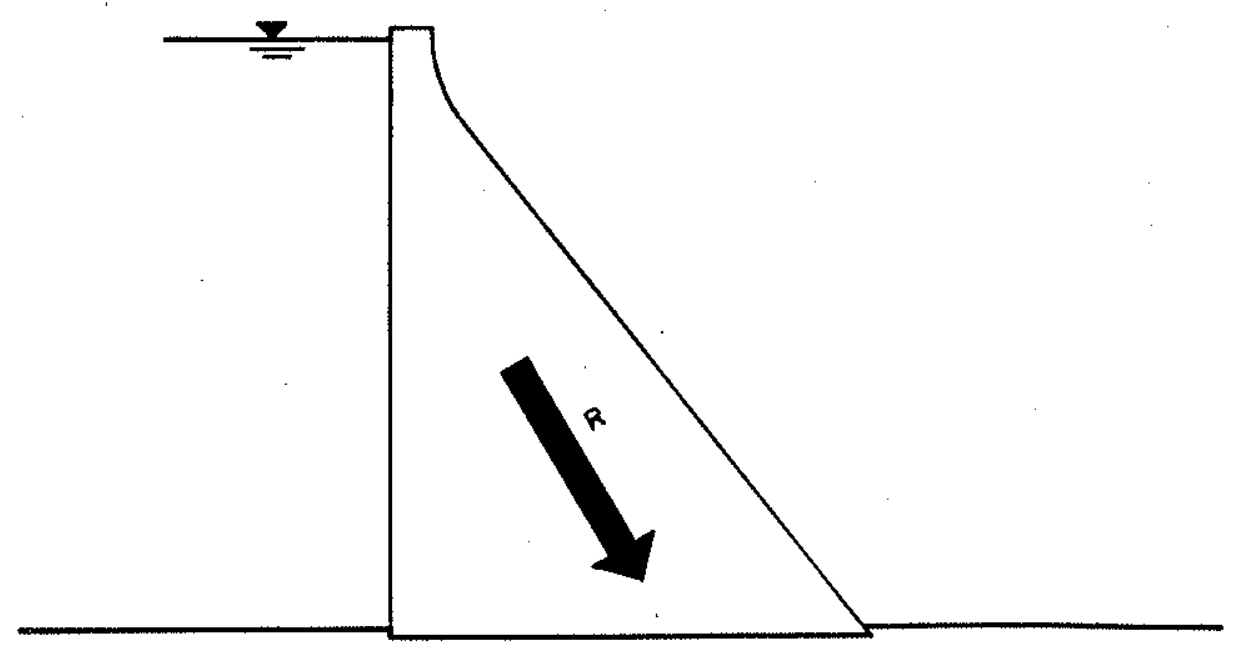

(1)

(2)

(a)

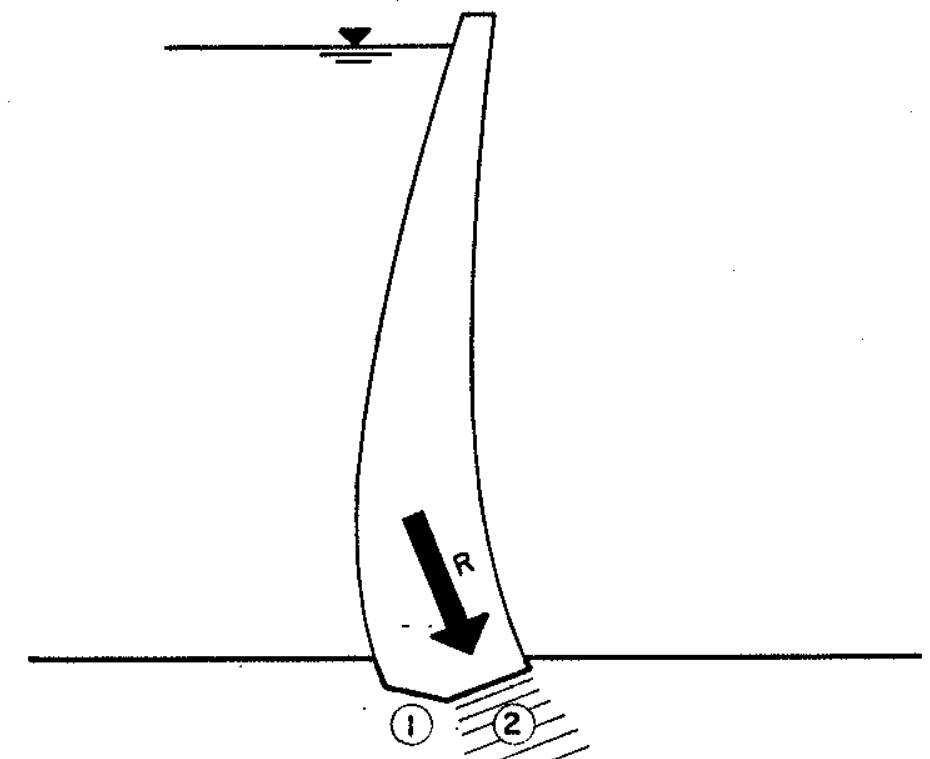

(b)

R - Resultante do empuxo da barragem nas fundâ

(1) - Zona de tração - abertura de fraturas "drenagem"

(2) - Zona de compressão - fechamento de fratü ras - "vedação"

Figura 16 - Esquema da distribuịção de zonas de tensão nos naci ços sob barragens do tipo gravidade (a) e arco (b). 


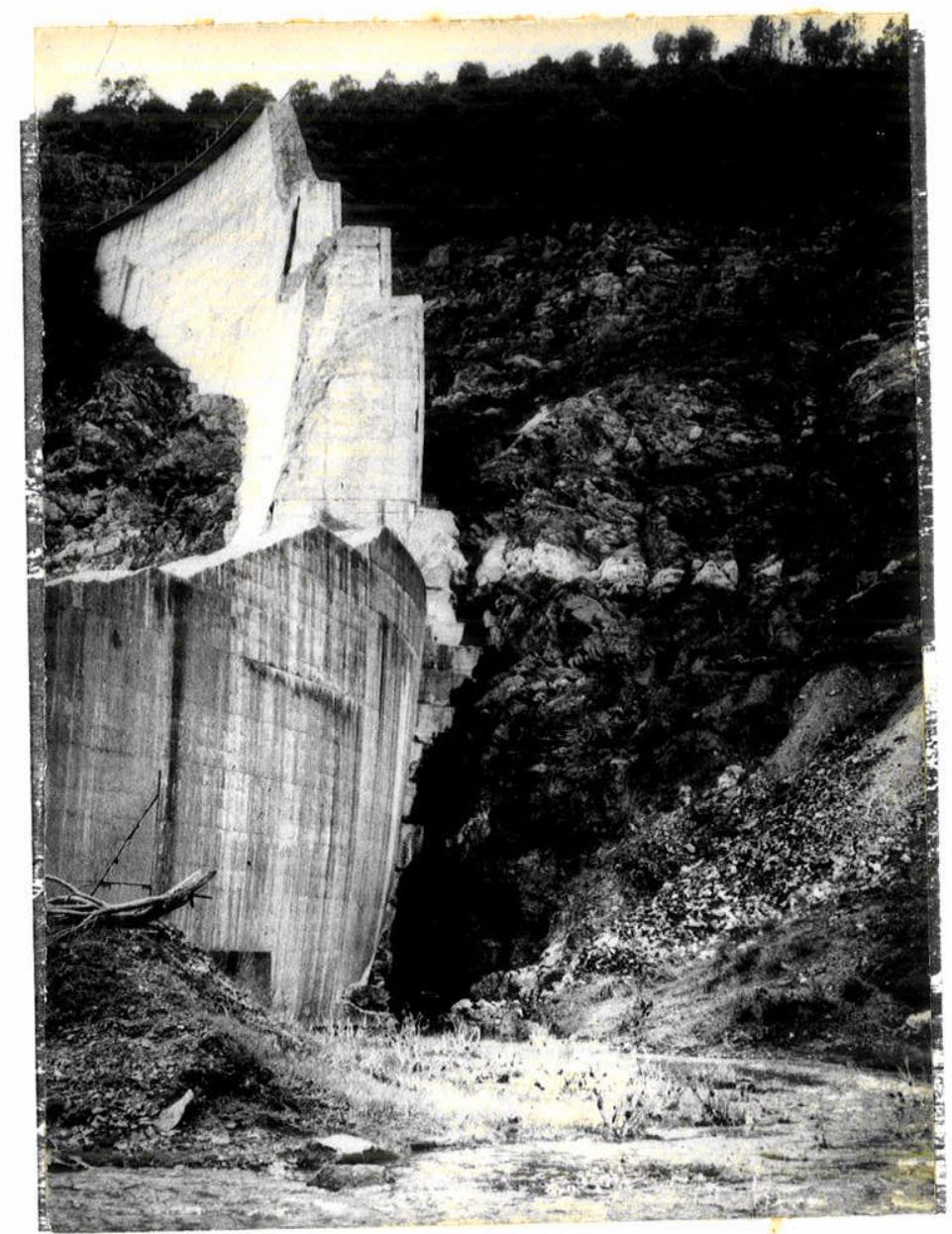

Figura 17 - Foto da ombreira direita da barragem de Malpasset (09/04/71). Observa-se a fenda de tração no pé de mon tante do arco. Esta fenda prolonga-se até a ombreira esquerda. 
sões hidrostāticas perigosas, para a estabilidade das fundações. A figura 18 retoma o exemplo de Malpasset onde o papel das duas zonas de tensões foi também apontado como uma das causas da ruptu ra. Contudo, não só as pressões hidrostäticas se desenvolvem peri gosamente mas também as forças de percolação que atuam nos contras tes de permeabilidade assim criados. A figura 1.9 apresenta um estu do de Louls (1968) que elucida, com um exemplo, o desenvolvimento destas forças.

SABARLY (1971) apresenta um caso real sobre os efeitos das tensões nas percolações. A figura 20 apresenta uma barragem cons truỉa em 1951. Em 1965 alguns furos da cortina de vedação passa ram a apresentar vazões altas. Os drenos no pé de jusante apresen tavam-se secos. Nessa época foram instalados os piezômetros que passaram a indicar praticamente o nivel de montante. Quando aber tos, funcionando como drenos, apresentavam uma vazão crescente com a subida do nível do reservatório como mostra a figura 21.

\section{VII. - LEVANTAMENTO HIDROGEOTECNICO DE CAMPO}

Atē recentemente, seja.em barragens projetadas no Brasil seja no exterior, os estudos de caracterização hidrogeotẹcnica "in situ" tem-se limitado aos que resultam a realização sistemātica dos ensaios de perda d'āgua sob pressão:

Atualmente existe contudo uma tendência em aprimorä-los devi do, em especial, aos progressos feitos no conhecimento teórico das leis de escoamento em meios fraturados e ao desenvolvimento dos mo delos de ànálise.

Com base neste desenvolvimento tem sido propostas metodolo 


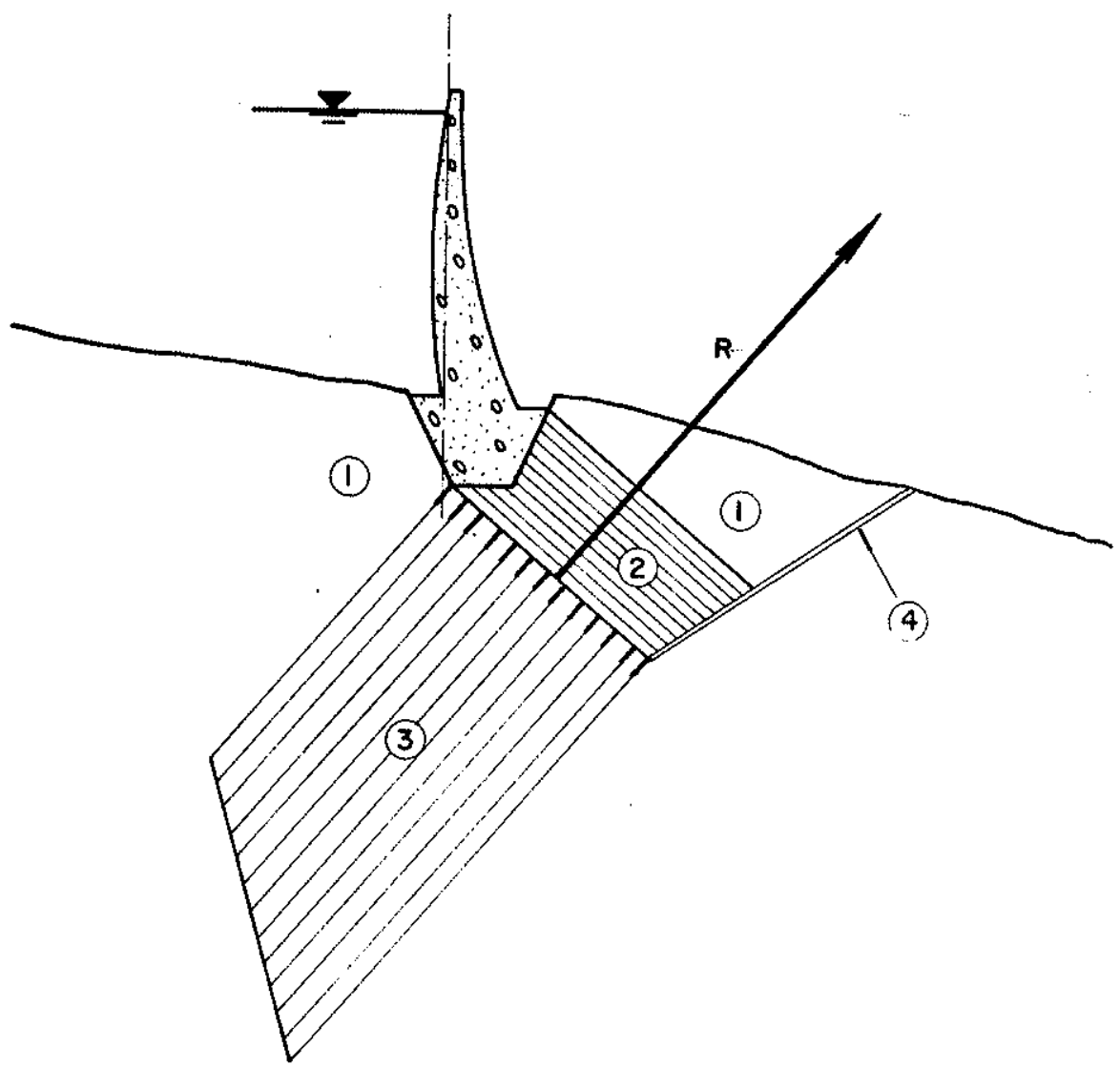

(1) Zona de permeabilidade $K_{0}$ (original)

(2) Zona de permeabilidade de $\mathrm{K}_{1}<\mathrm{Ko} / 100$ sob influência das tensões ("Veđação" na foliação do maciço gnāissico)

(3) Subpressões (de resultante R) = pressão hi drostática total

(4) Falha

Figura 18 - Subpressões em Malpasset (BELLIER, 1976). 
(a)

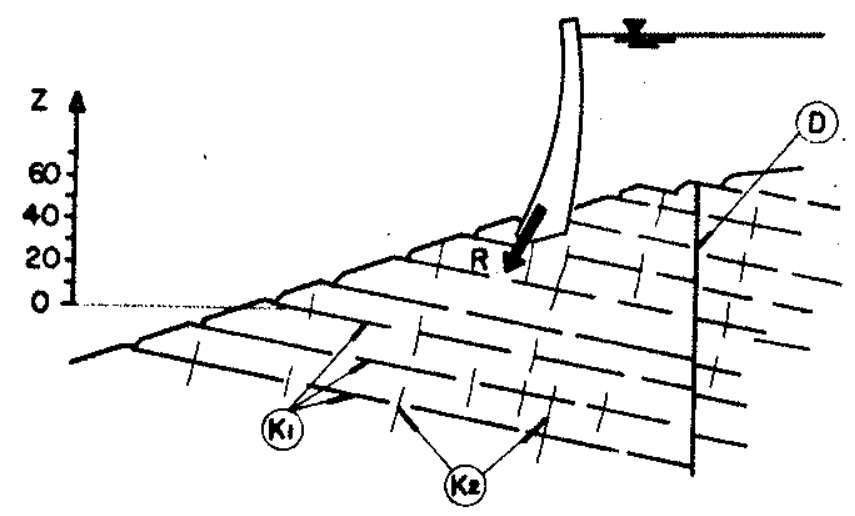

(D).
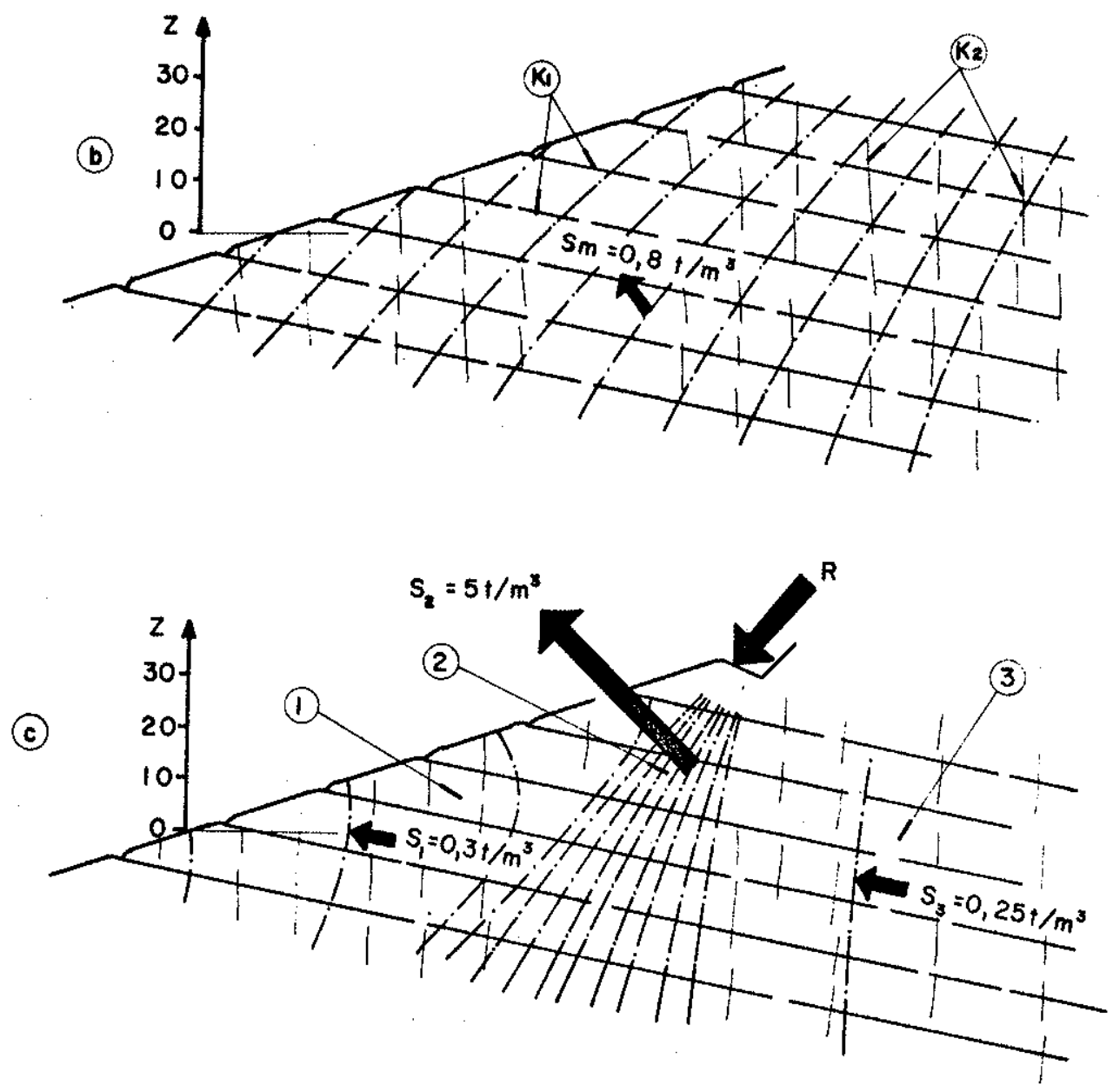

(a) Dados geométricos e hidräulicos do exemplo considerado

$\mathrm{R}$ - empuxo da barragem $\mathrm{KI}$ - fraturas principais

D - descontinuidade aberta K2 - fraturas secundärias

(b) Kl de abertura constante $\mathrm{S}$ - força de percolação

(c) Kl de abertura variävel sob ação de $R$

$S$ - força de percolação

(1) zona de trações induzidas pela compressão

(2) zona de compressão

(3) zona de tração pura

Figura 19 - Forças de percolação desenvolvidas sob a ação de ten sões (LOUIS, 1968). 


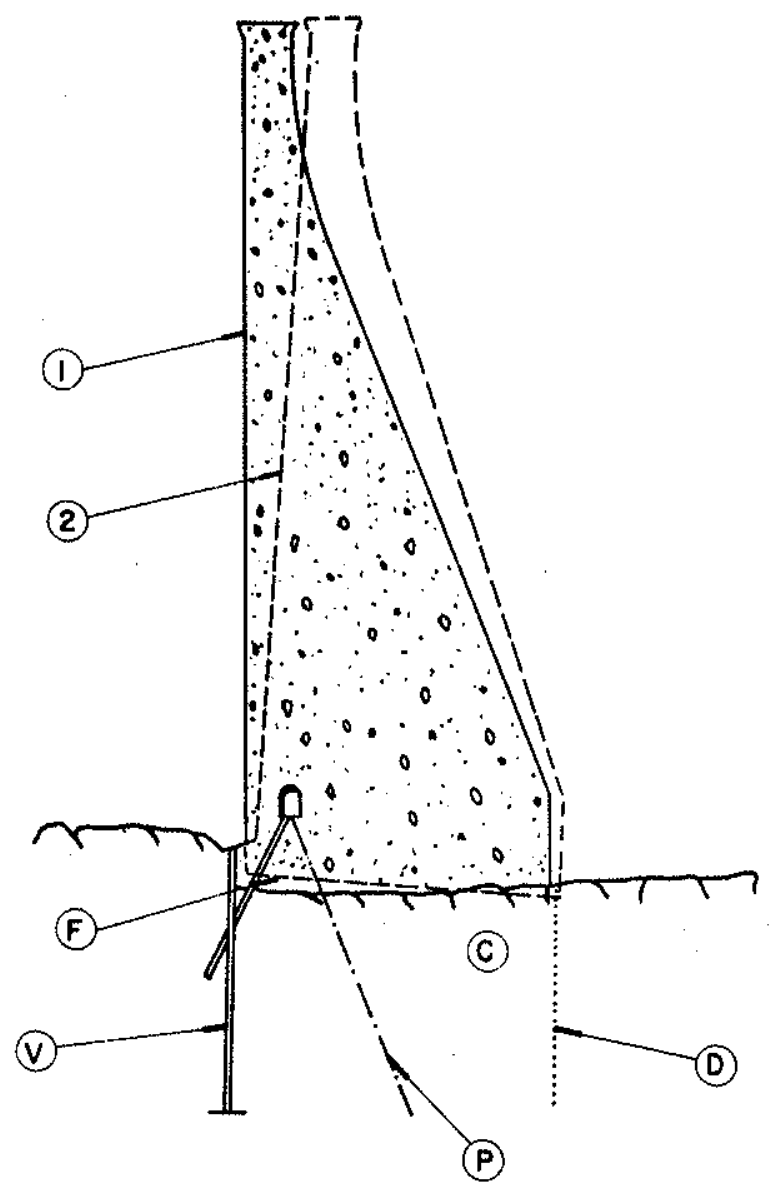

(1) Reservatóṛio vazio (2) Reservató rio cheio

F - fratura aberta alimentando os $\mathrm{p} i$ ezômetros

C - Zona comprimida, "estanque"

$V$ - Furo da cortina de vedação

P - Piezômetro

D - Dreno de jusante 


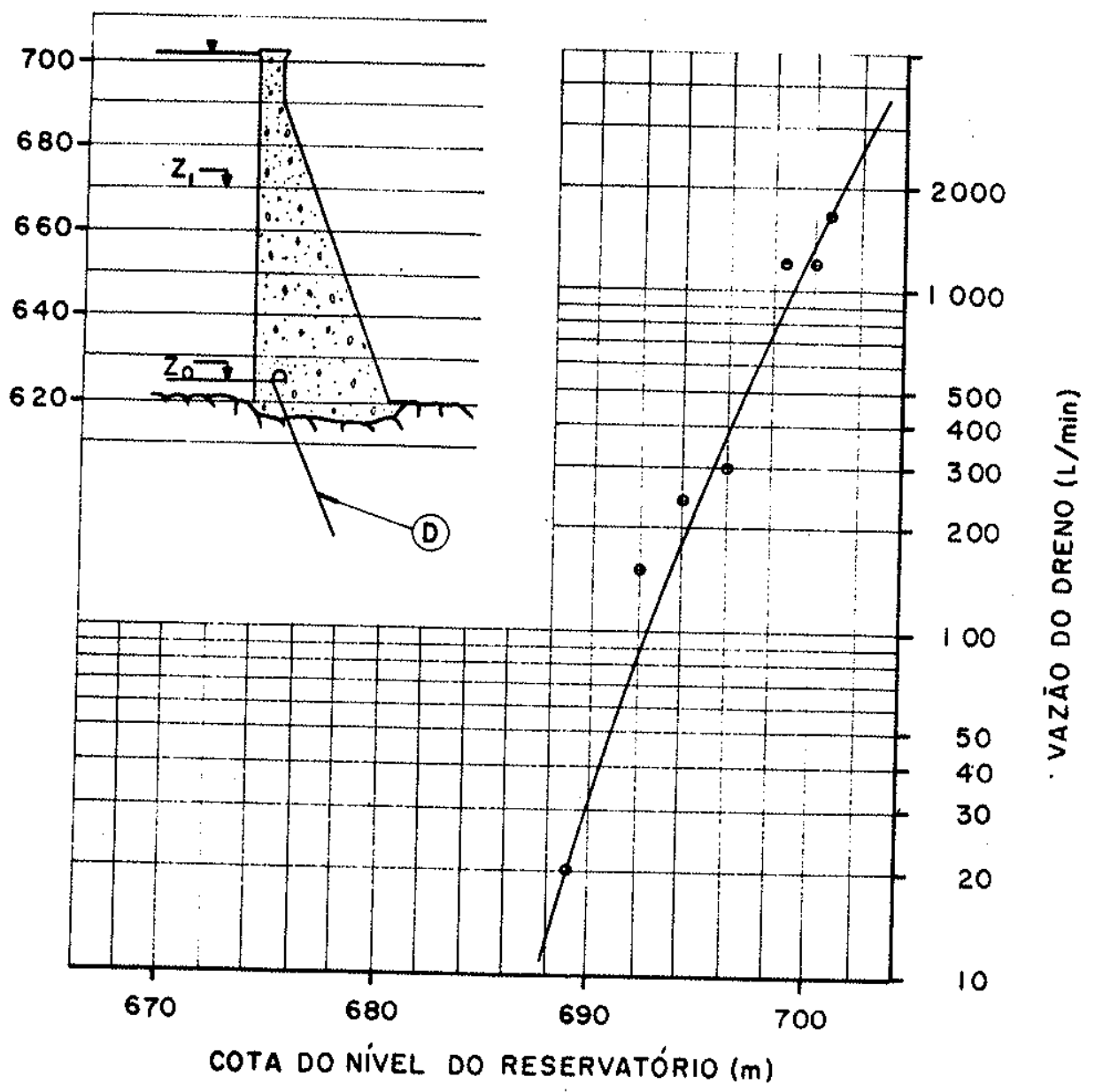

Figura 21 - Correlação entre a vazão do dreno e o nível do reservạ tōrio (SABARLY, 1974). 
gias (embora aplicadas ainda em poucos locais) para uma caracteri zação hidrogeotécnica mais adequada dos maciços. Tais metodologias propõem a realização dos estudos hidrogeotēenicos segundo três conjuntos principais de pesquisas:

1. - Levantamento de dados de interesse à Hidrogeotecnia (identifi cação de litologias, levantamentos estruturais).

2. Ensaios de permeabilidade.

3. - Piezometria.

VII.1. - Levantamento de dados de interesse à Hidrogeotecnia

Este levantamento corresponde às investigações geológicas e geotēcnicas dos locais de implantação de barragens cujos resulta dos são ponderados à luz da caracterização hidrogeotécnica.

Incluem-se neste levantamento portanto a identificação das litologias presentes e de suas caracteristicas estruturais.

- levantamento estrutural permite definir os principais siste mas de fraturas através de tratamentos estatisticos (diagramas de Schmidt). Alëm da orientação, outras características são de impor tância para a análise hidräulica dos maciços. Para cada sistema de fine-se"a intensidade do fraturamento: 'nümero de fraturas por me tro. Outro parâmetro de definição importante é o grau de extensão ou persistência das fraturas elementares de cada sistema. Ainda ao nivel de cada fratura,a abertura, rugosidade e preenchimento, são tam bém parâmetros importantes à serem definidos. De maneira a aperfeiçoar a anälise estatística tradicional, no sentido de uma melhor caracterização hidräulica do meio fỉsico, Lours (1974) propôs a ponderação dessa anālise estatistica com os parâmetros im portantes para essa caracterização: a extensão, a abertura das fra turas e a vazão pontual (quando em zonas aquiferas). Dessa forma, faz-se ressaltar, na anālise estatística, os sistemas de fraturas 
mais importantes do ponto de vista hidráulico, ao mesmo tempo em que os sistemas secundārios, ainda que compreendendo um nümero maior de fraturas, acabam por perder peso na análise geral.

- levantamento de todos estes parâmetros estruturais è em geral feito à superfície, através da análise dos afloramentos, ou em subsuperfície atravēs de sondagens, poços e galerias.

Contudo, a obtenção dos parâmetros hidráulicos, especialmente a abertura e a rugosidade das fraturas está sujeita a severas limi tações. Por um lado, tais medidas estão sujeitas a erros devido a alterações das fraturas em afloramentos ou perturbações provocadas pelos meios de investigação usados (sondagens, poços e galerias). Por outro lado, tem-se acesso a porções muito restritas do maciço investigado não se podendo dotar tais medidas da representativida de desejada.

Assim, vãrios autores voltam-se à necessidade de execução dos ensaios de permeabilidade cujos resultados acabam por traduzir glo balmente os efeitos dos parâmetros de difícil medida no campo.

Deve-se mencionar a introdução recente da tëcnica de amostra gem integral nas sondagens rotativas por ROCHA (1971) que alëm de permitir um melhor conhecimento de feições geológicas (FRANCISS e BRITO, 1971) permite obter medidas mais confiáveis de parâmetros hi drāulicos de fraturas elementares do que em testemunhos de sonda gens convencionais. Com efeito, a realização de sondagens com a mostragem integral na barragem de Agua Vermelha (CESP) permitiu es timar teoricamente as permeabilidades dos maciços. Contudo, não se prescindiu dos resultados dos ensaios de permeabilidade realizados nas mesmas sondagens, que serviram para corrigir os valores calcu lados teoricamente (FRANCISS e ROCHA, 1976). 


\section{VII.2. - Ensaios de permeabilidade}

Embora a determinação da permeabilidade dos meios fraturados possa ser feita através de vārios tipos de ensaios, os ensaios mais frequentemente usados são os denominados de perda d'água sob pres são. Tais ensaios resultam da proposta de LUGEON (1933) que, contụ do, tinha objetivos diversos. Originalmente, os ensaios Lugeon cor respondiam a um critério simples para diagnosticar a necessidade ou não da realização de cortinas de vedação em barragens. o critê rio da unidade Lugeon (absorção de $1 \mathrm{~L} / \mathrm{m} / \mathrm{min}$ sob uma pressão de $10 \mathrm{~kg} / \mathrm{cm}^{2}$ ) correspondia ao limite empirico, além do qual se impu nha a execução do tratamento de impermeabilização em fundações de barragens.

No estudo de fundações de barragens brasileiras, o ensaio tem sido sistematicamente realizado nas sondagens rotativas de pros pecção segundo metodologia apresentada por OLIVEIRA, SILVA e FERREIRA JR. (1975) .

A aplicação dos ensaios de perda d'ãgua sob pressão, para de terminação das caracteristicas hidräulicas dos maciços rochosos, está sujeita a uma série de limitações pois a interpretação normal mente efetuada do ensaio pressupõe :

- que o ensaio tenha sido realizado sob um regime de escoamento la minar;

- que o meio não tenha sofrido nenhuma perturbação;

- que o regime seja permanente;

- que o fluxo d'ägua seja radial;

- que o meio seja homogêneo, isōtropo e contỉnuo.

Hä basicamente duas linhas principais de pesquisa visando re solver estas limitações. Numa delas os autores procuram interpre 
tar, de forma mais adequada, o fluxo radial que se estabelece nas fraturas, nos ensaios tradicionais. Esta anālise tem como base os estudos teóricos desenvolvidos sobre as leis de escoamento em fra turas e os resultados de ensaios de laboratörio. Na outra, os auto res procuram ir além, aperfeiçoando o ensaio em si.

Constituem exemplos de primeira linha de pesquisa os estudos desenvolvidos por FRANCISS e ROCHA (1970); anteriormente citados. E tambëm os estudos de QUADROS (1981). Nestes estudos, são adotados valores de rugosidade, cuja influência no fluxo d'água foi previa mente determinada em laboratório, e são estabelecidas correlações entre as vazões e as cargas efetivas do ensaio e as abertura das fraturas. Tais correlações são feitas considerando a distribuição dos trechos da fratura em que o regime de fluxo é laminar, transi tório e turbulento. Tais estudos constituem um progresso importan te para a interpretação adequada dos ensaios tradicionais de per da d'āgua sob pressão, embora trate-se ainda de uma aproximação em relação ao que efetivamente ocorre nas fraturas ensaiadas "in situ".

Como exemplo da segunda linha de pesquisa, essencialmente vin culada à primeira, pode-se citar a proposta de LOUIS (1970) em se realizar ensaios com uma "sonda hidráulica tripla". O ensaio ..ē mais sofisticado e exige um controle piezométrico em torno do tre cho ensaiado. Desconhecem-se contudo casos de aplicação com uso intensivo da nova técnica em locais de barragens.

Outros ensaios, alēm dos convencionais de perda d'āgua sob pressão podem ser citados, embora com aplicação menos frequlente: ensaios geofísicos aplicados à Hidrogeotecnia (BOLLO e RIVET, 1968), ensaios de bombeamento e de traçadores (SILVA, ARAOJO e MONTICELLI, 1978), ensaios de drenabilidade (PEÑA e outros, 1970) e ensaios hí drogeotēcnicos globais (OLIVEIRA e CORREA FILHO, 1976). 


\section{VII.3. - Piezometria}

- levantamento piezométrico dos aquíferos fraturados é fundạ mental para se completar o quadro hidrāulico do maciço. o levanta mento de dados estruturais e os resultados dos ensaios de permeabi lidade, anteriormente analisados, permitem definir um quadro do maciço, que não ë suficiente para a realização dos estudos de pre visão do comportamento, assim que o maciço for solicitado por no vas condições. A piezometria do maciço estudado deve permitir a de finição:

- das condições Iimites, importantes para o problema hidrogeo. técnico colocado: zonas de alimentação e descarga dos aquíferos, fronteiras "impermeâveis", etc;

- das principais redes de fluxo locais através do levantamento das equipotenciais;

- da interrelação dos aquíferos principais que, em geral, apresen tam um comportamento confinado nos meios fraturados;

- da relação dos aquíferos com os niveis d'āgua superficiais,rios, lagos, etc;

- da relação dos aquíferos com as chuvas.

Para a realização desta anālise piezomētrica é fundamental a caracterização geolōgica e a anālise estrutural prévias do local estudado. Em geral, a análise é efetuada através da instalação de piezômetros, usualmente denominados do tipo Casagrande, em furos de sondagens. Dois requisitos principais são reconhecidos na ins talação destes piezômetros:

- o trecho de medida não deve perturbar a rede de escoamento;

- trecho deve ser pontual de maneira a permitir a medida de uma equipotencial.

Tais requisitos indicam a necessidade de se instalar o trecho 
de medida de forma objetiva, em caminhos supostamente preferenciais da percolação e com comprimentos suficientemente curtos de maneira a não envolver mais de um aquífero. A figura 25 apresenta um esque ma simples de montagem de um piezômetro.

\section{VIII. - ESTUDOS HIDROGEOTECNICOS}

Os dados hidrogeotécnicos, levantados nos trabalhos de campo, têm sido submetidos a um tratamento pouco consequente, na maior parte dos projetos das barragens. São raros os casos em que este tratamento é aprofundado visando a previsão do comportamento dos maciços, quando do enchimento dos reservatórios.

Até a presente data os estudos se limitaram a identificar as zonas mais permeāveis do maciço e quantificá-las em termos de coe ficientes de permeabilidade obtidos nos ensaios de perda d'ägua sob pressão. Assim, o uso destes estudos no projeto se restringe à orientação dos trabalhos de tratamento das fundações, raramente a vançando no campo da previsão dos comportamentos.

Esta situação resulta, por um lado, do fato dos projetos faze rem uso de regras empiricas no estabelecimento das subpressões e, por outro lado, do fato dos avanços alcançados nos estudos hidrogeotēcnicos serem recentes.

o tratamento mais aprofundado dos dados hidrogeotēcnicos tem sido efetuado atravēs de modelos, matemáticos ou físicos. Alguns exemplos são apresentados na tabela 4 .

Contudo, de uma maneira geral, a complexidade dos modelos cönvencionais não estimula sua utilização freqhente. Objetivando vulgarizar a simulação eletroanalógica,FRANCISS (1969) desenvolveu técnica de execução de modelos utilizando recursos extremamente simples, possibilitan do resolver, com rapidez e economia, os mais variados problemas de percolação. O estudo deste autor sobre a barragem de Alqueva 


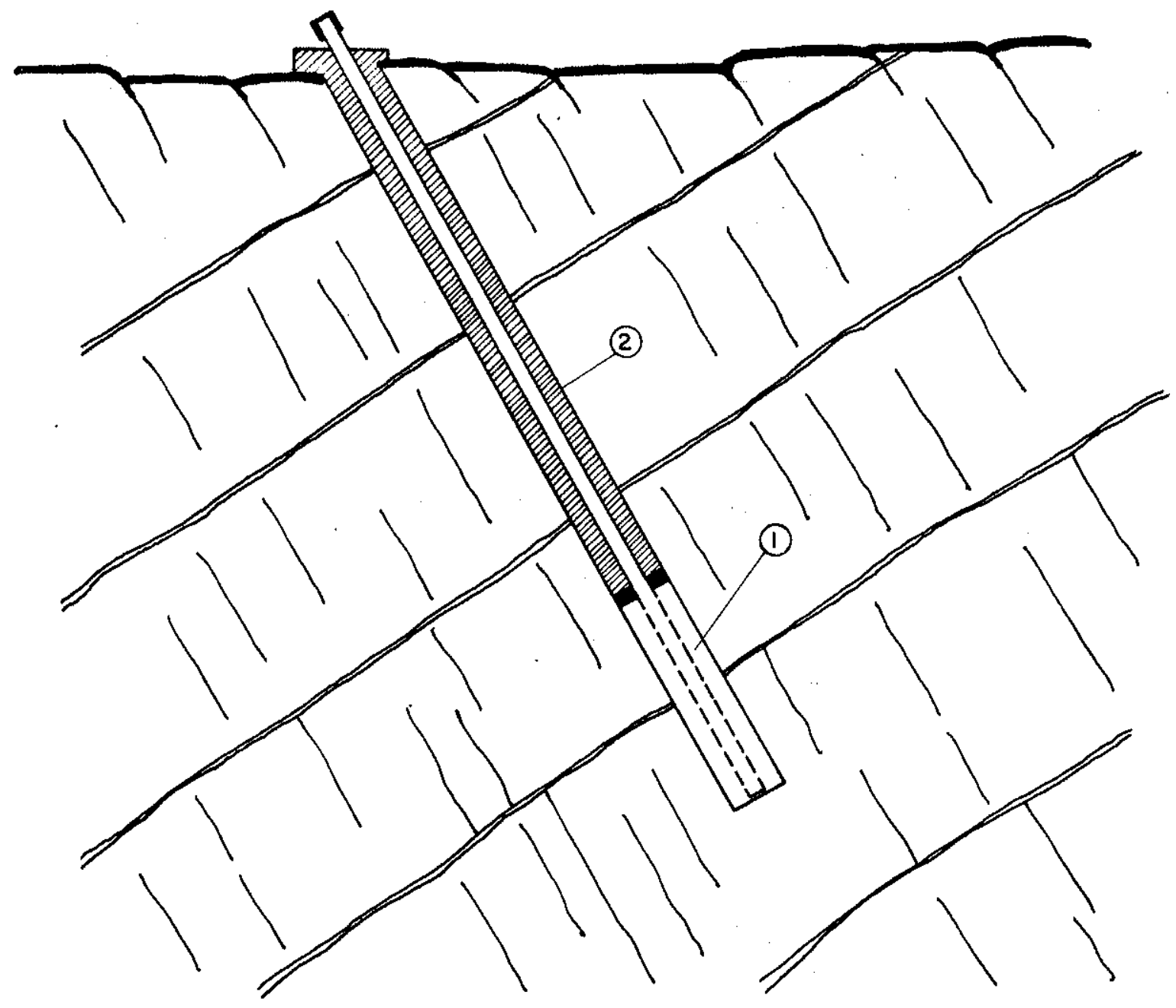

(1) Trecho de medida

(2) Trecho vedado

Figura 22 - Esquema de montagem de piezômetro num furo de sondà gem. 


\begin{tabular}{|c|c|c|c|c|c|}
\hline BARRAGEM & MACIÇO & $\begin{array}{l}\text { PRINCIPAIS DADOS } \\
\text { DE CAMPO }\end{array}$ & $\begin{array}{l}\text { MODELO DE } \\
\text { ANALISE }\end{array}$ & PRINCIPAIS RESULTADOS & $\begin{array}{l}\text { REFERENCIA } \\
\text { BIBLIOGRAFICA }\end{array}$ \\
\hline Kurobe no 4 & Granito & $\begin{array}{l}\text { Ensaios tipo Lu- } \\
\text { geon } \\
\text { Piezometria }\end{array}$ & $\begin{array}{l}\text { Eletroanalögicos } \\
\text { bi e tridimensio } \\
\text { nais }\end{array}$ & $\begin{array}{l}\text { Avaliação dos efeitos da } \\
\text { cortina de vedação e da rê } \\
\text { de de drenagem } \\
\text { Comprovação dos modelos com } \\
\text { o enchimento do reservató- } \\
\text { rio } \\
\text { Orientação de drenagem com } \\
\text { plementar }\end{array}$ & YOKOTA, 1963 \\
\hline $\begin{array}{l}\text { Alqueva lom } \\
\text { breira es- } \\
\text { querda) }\end{array}$ & $\begin{array}{l}\text { Com falha } \\
\text { importante }\end{array}$ & $\begin{array}{l}\text { Anälise estrutu- } \\
\text { ral }\end{array}$ & $\begin{array}{l}\text { Eletroanalógico } \\
\text { simplificado, trí } \\
\text { dimensional }\end{array}$ & $\begin{array}{l}\text { Diagrama de distribuição de } \\
\text { pressões hidrodinâmicas. }\end{array}$ & FRANCISS, 1970 \\
\hline $\begin{array}{l}\text { Grand Mai } \\
\text { son (arco } \\
200 \mathrm{~m} \text { de a1 } \\
\text { tura) }\end{array}$ & $\begin{array}{l}\text { Gnaisse e } \\
\text { anfibolitos }\end{array}$ & $\begin{array}{l}\text { Anālise estrutu- } \\
\text { ral } \\
\text { Ensaios de per } \\
\text { meabilidade } \\
\text { Piezometria }\end{array}$ & $\begin{array}{l}\text { Matemático tridi } \\
\text { mensional }\end{array}$ & $\begin{array}{l}\text { Previsão do comportamento } \\
\text { Orientaçóes dos tratamen } \\
\text { tos de vedação e drenagem }\end{array}$ & LOUIS, 1974 \\
\hline $\begin{array}{l}\text { Itaipu } \\
\text { (gravidade, } \\
\text { l80 m de al } \\
\text { tura) }\end{array}$ & Basalto & $\begin{array}{l}\text { Ensaios de perda } \\
\text { d'água sob pres- } \\
\text { são }\end{array}$ & $\begin{array}{l}\text { Eletro analógico } \\
\text { simplificado, bi } \\
\text { dimensional }\end{array}$ & $\begin{array}{l}\text { Previsão de subpressöes e } \\
\text { vazões } \\
\text { Orientação da drenagem } \\
\text { (galeria) }\end{array}$ & ABRAHÃO, 1978 \\
\hline
\end{tabular}

Tabela 4 - Exemplos de estudos hidrogeotēcnicos em modelos 
(FRANCISS, 1970) demonstra sua aplicação mesmo em modelos tridimen sionais. Finalmente, a mesma técnica foi aplicada a um caso de barragem sobre basaltos por ABRAHÃO (1978). Os dois exemplos estão assinalados na tabela 4 .

\section{IX. - TRATAMENTO DAS FUNDAÇOES}

Como jä foi exposto, relembra-se que os "materiais" que cons tituem as fundações não podem ser nem selecionados, nem organiza dos, camo foram os materiais de construção das barragens. No processo de se adequar o melhor possivel os "materiais" naturais de fundação ao equilïbrio de sejado do conjunto barragem x fundações destacam-se alguns procedimentos bäsi cos de projeto. Os primeiros procedimentos envolvem a seleção da melhor alterna tiva do local da barragem. Em seguida as escavações proporcionam a eliminação de porções indesejāveis dos maciços. Finalmente, é usual a aplicação de trata mentos dirigidos para a solução dos problemas impostos pela percolação d'ägua. Estes tratamentos são basicamente de dois tipos: a vedação e a drenagem. A tẻcnica de vedação mais usual tem sido a injeção de caldas de cimento atravēs de furos dispostos numa ou mais linhas. o dispositivo de vedação assim construido tem sido correntemente denominado de cortina de vedąão. A tẻcnica de drenagem usual tem sido aplicada através da abertura de furos de pequeno diâmetro dispostos em geral ao longo de uma linha, à jusante da cortina de vedação. O dispositivo assim criado tem sido denominado rede de drenagem.

o papel desempenhado pelas cortinas de vedação e redes de drenagem cons truidas nos meios descontinuos continua atualmente em questão. As controvërsias, que envolvem especialmente as cortinas de vedação, tem dado margem, em congres sos, a debates nem sempre profícuos. Embora não seja a ünica, a principal razão para esse fato deve resultar da grande variedade de meios descontinuos exis tentes e da dificuḷade em se extrapolar os resultados de análises 
teóricas para o que realmente acontece na natureza. Cada autor, ao apresentar seu trabalho em congressos, expõe sua experiência pró pria no assunto, o que significa, em geral, uma limitação importan te: são casos específicos e por isso as conclusões obtidas são dị ficilmente generalizäveis. Os resultados de cada experiência podem evidentemente ser transpostos para outros casos, mas na medida em que seja possivel estabelecer termos seguros de comparação. Se tal pressuposto não for "a priori" estabelecido, a consequência inevi tāvel é a provocação de extensos e inöcuos debates, de que as ses sões tēcnicas dos congressos estão plenas de exemplos.

Desta forma, evitando incorrer no mesmo erro, procura-se tão somente estabelecer os conceitos fundamentais do assunto. Em se guida, apresenta-se um breve apanhado histörico do uso dos trata mentos e das principais controvērsias surgidas no meio técnico, de maneira a identificar os principais traços da evolução dos con ceitos.

\section{IX.1. - Conceitos fundamentais}

No 99 Congresso Internacional de Grandes Barragens, GILG (1967) apresentou um exemplo pirātico que traduz, de forma elucida tiva, os efeitos principais de cada um dos tratamentos: vedação é drenagem. Trata-se do caso da barragem de Isola (Suiça). No maciço de fundação dessa barragem (arco, $45 \mathrm{~m}$ de altura e $290 \mathrm{~m}$ de compri mento), constituido por gnaisse com fraturas a cada $10 \mathrm{~cm}$, preenchi das por peliculas de argila de cerca de $1 \mathrm{~mm}$, foi executada uma cortina de vedação. As absorções foram irrisórias. Com o primeiro enchimento do reservatōrio, verificou-se grandes valores de subpres são (55\% em mëdia da carga total) sob a barragem e à jusante, ape sar das vazões serem minimas (26 L/min para os 34 drenos rasos). Nova injeção (furos de $2 \mathrm{em} 2 \mathrm{~m} \operatorname{com} 40 \mathrm{~m}$ de profundidade) foi rea 
lizada com calda de cimento e as absorções foram ainda menores. Tentou-se então a injeção com resina orgânica (solução de resorci na) verificando-se grandes absorções num ensaio realizado para ve rificar sua eficiência. No entanto, a realização de uma cortina com esse material não foi justificada dado o alto custo envolvido. Nessa altura, as vazões totais tinham diminuỉdo atē os drenos apre sentarem saỉdas d'āgua gota a gota. No entanto, as subpressões continuavem altas. Decidiu-se então executar uma rede de drenagem com furos profundos $(10$ a $15 \mathrm{~m})$ com espaçamento de $3 \mathrm{~m}$. "Conseguiuse obter,gracas a este método, uma importante redução da subpressão sob a barragem e mesmo sua eliminasão à jusante". A vazão d'ägua drenada passou a ser de cerca de $70 \mathrm{~L} / \mathrm{min}$.

o exemplo descrito reflete, com efeito, um conceito fundamen tal: as vazões da percolação d'āgua são diminuídas pelas injeções e aumentadas pela drenagem. No exemplo, as injeções não surtiram qualquer efeito na ação das subpressões, o que nos leva a retomar a análise das controvérsias acerca de papel das cortinas. Com efei to, no exemplo das fundąões da barragem de Isola, as subpressões não respondem à tentativa de se melhorar a vedação através de mais injeções de calda de cimento. Tal fato não pode ser generali zado e se deve certamente à baixa permeabilidade original do maci ço de fundação (absorções de calda desprezíveis) não tendo sido possivel criar, através das injeções, um contraste de permeabilida de tal que provocasse uma perda de carga significativa.

A conclusão da experiência, realizada por Gilg ("iorsequiu-se obter gragas a este método uma importante redugão da subpressão sob a barragem e mesmo sua eliminasão a jusante), permite que se perce ba que hã 14 anos atrás o autor, e provavelmente uma boa parte do meio tēcnico, ainda caminhava no sentido de melhor esclarecer o 
papel dos dois tratamentos, ao mesmo tempo de efeitos opostos e complementares (se adequadamente aplicados) no controle da percola ção d'ãgua das fundações.

o estāgio de conhecimento do assunto, naquela época, pode ser ainda caracterizado pela oportunidade aproveitada no mesmo Congres so, por TER MINASSIAN, SABARLY e LONDE (1967) de esclarecer o me Ihor possivel o papel de cada um dos tratamentos. Retomam-se os conceitos fundamentais apresentados por esses autores: a figura 23 mostra a distribuição tỉpica das cargas piezométricas sob ação da vedação e da drenagem. Os autores consideram como premissa um regi me permanente e laminar. E expõem os seguintes conceitos fundamen tais para qualquer anälise do assunto:

- "num macigo homogêneo de permeabilidade $K$, a vazão depende de $K$, a velocidade em cada ponto depende de $K$ e da abertura das fraturas, a pressão em cada ponto não depende nem de $K$, nem da abertura das fraturas".

- "num macigo fraturado heterogêneo, caracterizado por diferentes coeficientes de permeabizidade, a pressão em cada ponto depende dos valores relativos destas permeabilidades, enquanto que as va zóes dependem de seus valores absolutos".

- "a vazão de percolacão $\vec{e}$ aumentada pela drenagem e reduzida pela vedasão".

Ao se introduzir nos maciços de fundação os tratamentos de vedação e drenagem, cria-se em ültima anālise, heterogeneidades artificiais. Os efeitos destas heterogeneidades, combinados com os referentes às heterogeneidades naturais (litologias, estruturas geo lögi.cas e tensões tectōnicas) e heterogeneidades mecânicas induz $\underline{i}$ das (efeito das tensões aplicadas pela barragem nas fundações) con dicionarão a distribuição de permeabilidade do meio que,juntamente 

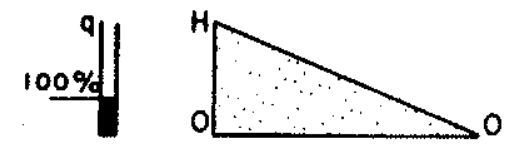

(a)
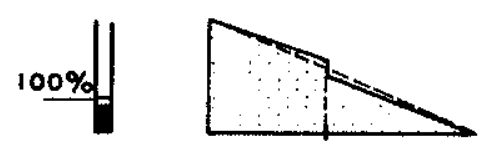

(b)
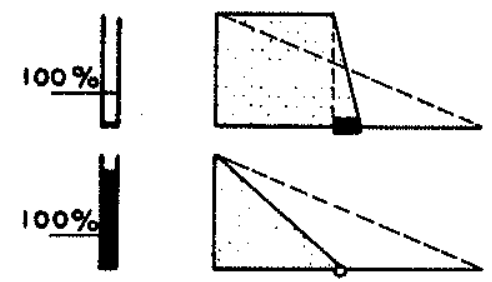

(c)
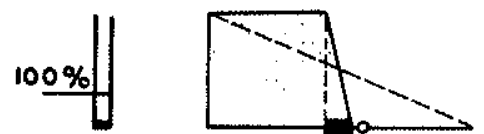

(d)
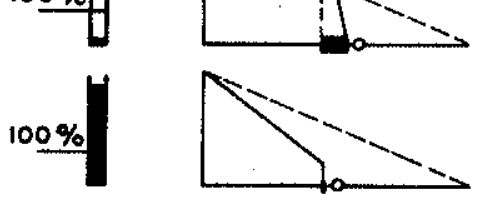

(e)

(f)

H - Carga do reservatório

q - vazão
a) escoamento natural
b) cortina de vedação inefi- ciente
c) cortina de vedação efí ciente
d) dreno
e) cortina eficiente mais dre
no
f) dreno mais cortina inefi- ciente.

Figura 23 - o papel dos tratamentos de fundação(TER MINASSIAN, SA BARLY e LONDE, 1967). 
com as condições limites do conjunto obra x meio físico,governarão as redes de fluxo, a distribuição das pressões hidrostāticas e for ças de escoamento e as vazões.

Os mesmos autores continuam a anālise do problema (figura 23 ):

- "uma cortina de vedasão não reduz apreciavelmente as vazões de percolasão e as pressões a jusante senão quando constitui uma zona de espessura notável e de permeabilidade muito menor que a permea bilidade do resto do macifo (casos b e $\underline{\mathrm{c}}$ da figura 23). Nestas con dicões, toda cortina de vedagão suporta a quase totalidade da car ga hidrostática de montante. Uma rede de drenagem colocada a jusan te seria inütil pois não reduzixia essa carga (caso e). Mas, para construir uma cortina de vedasão por injesão ciāssica, $\dot{e}$ necessáa rio que o macigo seja suficientemente permeável, pois a penetra gão limitada da calda reduz mito pouco e apenas localmente a permeabilidade natural do terreno. Assim, a cortina seria insufi ciente". (caso das andações da barragen ce Isola, exposto anteriomente e caso

Por outro lado, a drenagem, ao provocar uma redução sensível das subpressões, eleva substancialmente a vazão (ainda o caso das fundações de Isola e os casos d e $\underline{f}$ da figura 23).

CASAGRANDE (1961) tambēm realiza uma análise de casos hipotē ticos que estão reproduzidos na figura 24 . Os casos apresentados, embora hipotéticos, tem o mérito de traduzir a devida relevância que o autor dã às feições geológicas das fundações que atuam como condicionantes primordiais co comportamento hidrogeotécnico.

Outro efeito importante da vedação e da drenagem é o produzí do nas pressões hidrostäticas e nas de escoamento. Supondo uma cor tina de vedação idealmente eficaz seu efeito no escoamento é ' pro duzir pressões hidrostāticas dirigidas perpendicularmente à barrei ra artificial (figura 25). Ao contrārio, uma drenagem provoca 
()

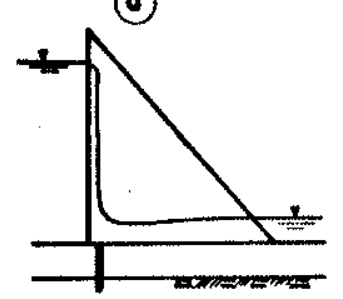

(b)
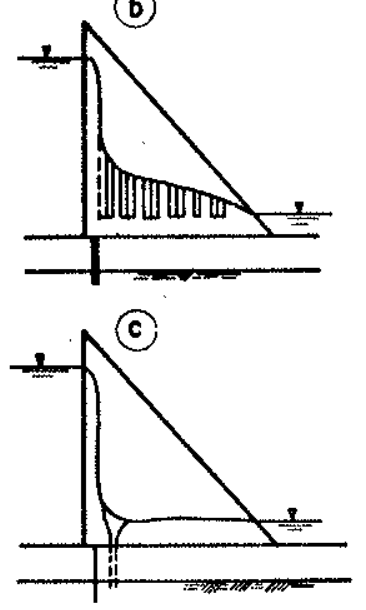

()

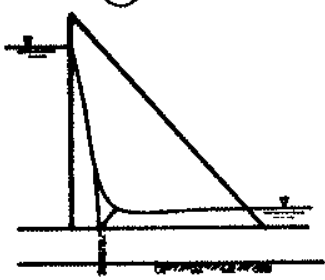

(e)

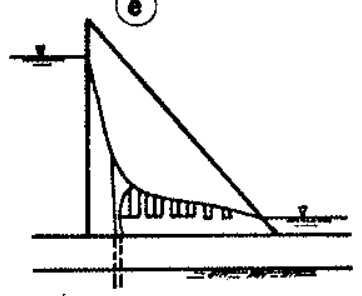

(1)

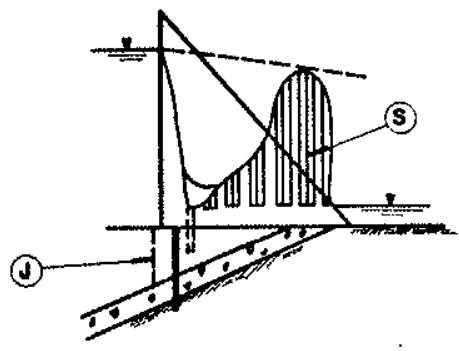

(b)

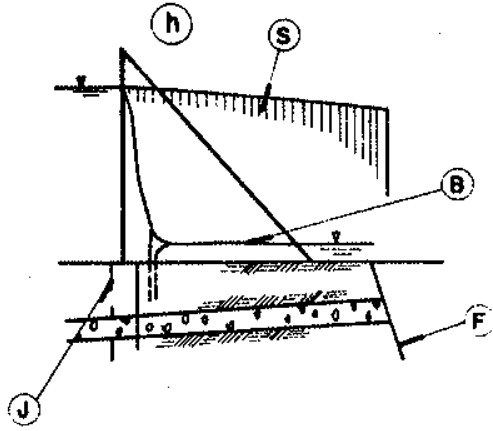

a) cortina de vedação perfeita

b) cortina de vedação razozvelmente eficiente, sem drenos

c) cortina de vedação razoavelmente eficiente, com drenos

d) drenagem eficiente - nivel dos drenos abaixo do nivel de jusante

e) drenagem eficiente - nivel dos drenos acima do nivel de jusante

f) drenagem deficiente - drenos com profundidade insuficien te para as condições da rocha.

g) condições geológícas originam subpressão excessiva - pro fundidade insuficiente dos drenos.

$$
\text { S - subpressões perigosas na base }
$$

h) condições geológicas causam pressões intersticiais peri gosas na rocha

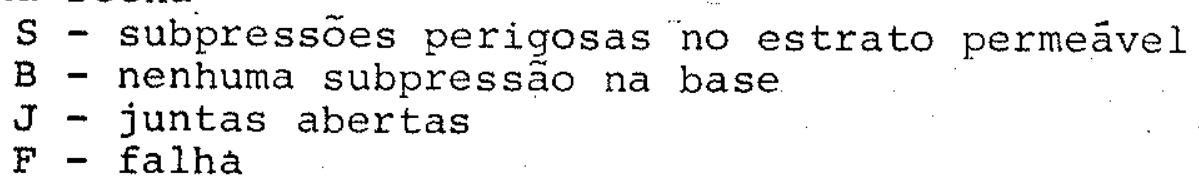

Figura 24 - Exemplos hipotēticos (CASAGRANDE, 1961). 
(a)
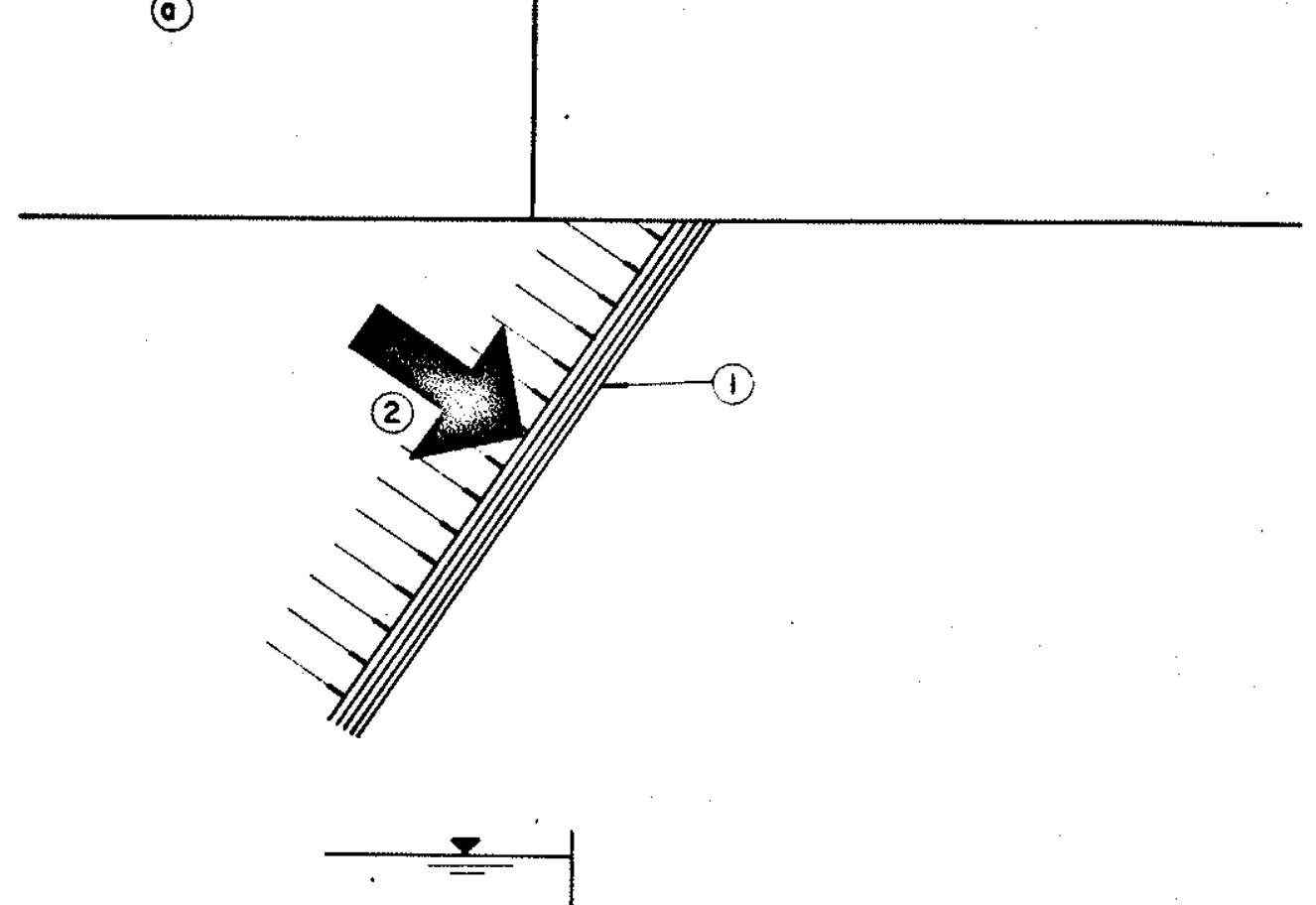

(b)

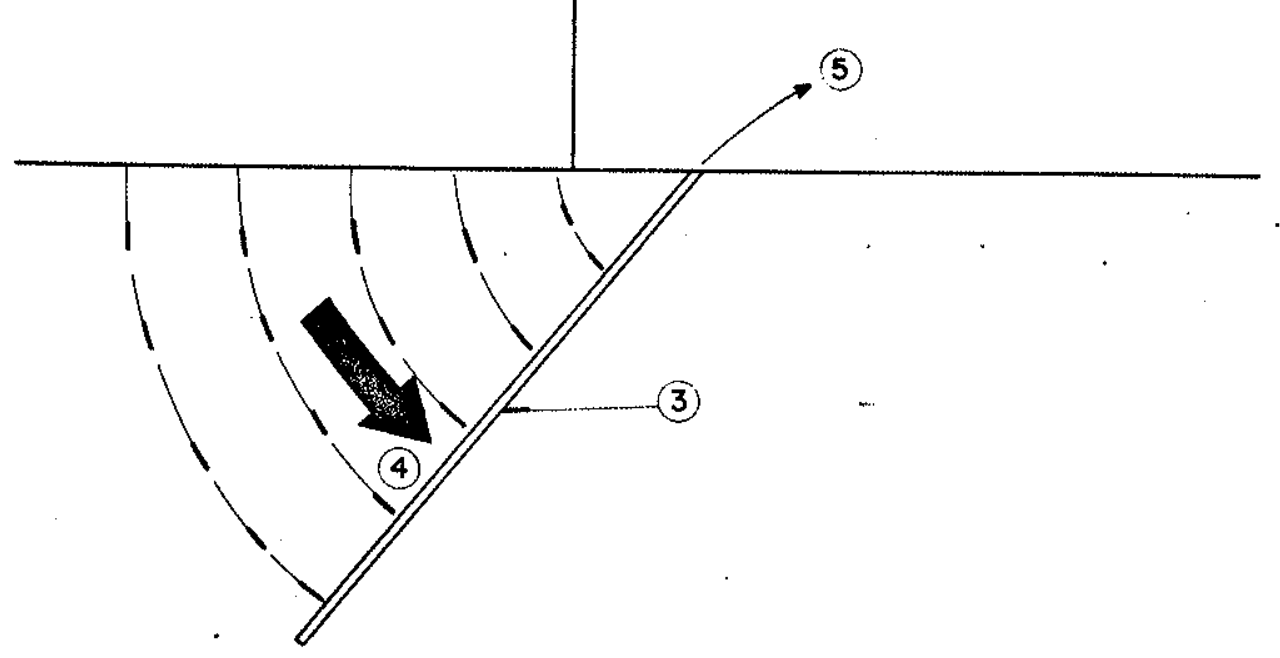

1) Cortina de vedação "perfeita"

2) Pressões hidrostäticas e resultante

3). Drenagem "perfeita"

4) Forças de escoamento e resultante

5) Vazão total das infiltrações na fun

Figura 25 - Comparação esquemätica entre os efeitos ideais da ve dação (a) e da drenagem (b). 
aparecimento de forças de escoamento dirigidas tangencialmente às linhas de fluxo (figura $25 \mathrm{~b}$ ).

A anälise acima efetuada foi propositalmente reduzida a uma simplicidade tal que embora não traduza a complexidade dos casos reais, permite compreender alçuns conceitos bäsicos através de formas idealiza das. Sem estes conceitos primários torna-se difícil senão impossi vel a compreensão daqueles casos.

IX.2. - Um breve apanhado histörico

A tentativa de se esboçar um quadro histórico da aplicação da vedação e drenagem em fundações de barragens, até os dias atuais, é importante na medida em que se tem por objetivo analisar não só a evolução do uso das técnicas em si, mas sobretudo a evolução dos conceitos.

o esboço deste quadro pode ser realizado basicamente através de um levantamento bibliográfico e seleção dos principais trabą Ihos publicados. Dada a extensão do levantamento proposto e da não disponibilidade de muitos dos trabalhos publicados, o quadro deve ser encarado com reservas por estar provavelmente incompleto. o quadro foi ainda complementado pelo levantamento dos principais a cidentes de barragens cujas causas respondiam a fenômenos de per colação d'āgua nas fundações. Estes acidentes constituem marcos ex tremamente significativos na evolução dos conceitos e das técnicas de controle das percolações. Ainda outros fatos importantes foram acrescidos.

Segundo GLOSSOP (1960), Bēxigny foi o inventor da tēcnica da injeção de meios naturais, na França em 1802. O acidente da bar ragem de Bouzey na França em 1895; levou Levy (MARY, 1965) a iden tificar as subpressões nas bases das barragens como esforços im portantes a serem considerados na estabilidade das barragens. Se 
gundo CAMBEFORT (1964) o grande desenvolvimento do processo de inje ção data do início da fase intensa de construção de grandes barra gens na França, entre 1920 e 1930. Em 1933, LUGEON publicou sua famosa obra "Barrages et Gëologie" onde define o critērio de vedạ ção de fundações de barragens, mais tarde conhecido como critério Lugeon, determinado pelo ensaio proposto por ele e que tambēm leva seu nome. Notamse que o critërio Iugeon não foi aceito universalmen te, uma vez que nos importantes trabalhos de vedação das funda ções de Hoover Dam realizados de 1938 a 1944, o critério utilizado foi o da qualidade de testemunhos obtidos nas sondagens (SIMONDS, 1951). Contudo, os trabalhos realizados surtiram efeito: as va zões que chegaram a atingir $7500 \mathrm{~L} / \mathrm{min}$ foram reduzidas em cerca de 90웅 (CASAGRANDE, 1961).

Em 1959 ocorre o acidente de MALPASSET provocado pela ação de subpressões nas fundações (figura 26) com profundas repercussões no meio técnico (OLIVEIRA, 1975). Atē então, a atuação das subpres sões em profundidade nos maciços tinha sido mais ou menos subesti mada. As fundações de Malpasset eram muito pouco permeáveis los trabalhos de injeção foram abandonados em função dos primeiros re sultados, extremamente baixos, de absorções de calda) e não se en contravam drenadas. Segundo LONDE (comunicação verbal em 1971) atë 1960, das 600 barragens arco construidas em todo o mundo, apenas duas fundações estavam drenadas, porém localmente, em função de estruturas geológicas particulares.

Esta afirmativa, contudo, é parcialmente contestada por TALO BRE (1967): "Ha muito tempo, os construtores de barragens, preocu pados com a segurança de suas obras, prestavam atencão às subpres sões, que agem na rocha. Quando do acidente de 2928 , a resistência do bloco central da barragem de San-Francis (USA), foi atribuida à presenga de furos drenantes destinados a reduzir as subpressões 
nos macicos de fundąãa. A barragem arco de Publino (Itälia), ter minada em 1953, as barragens-arco de Chah-Pahtevi (Iran) e Kurobe (Japão) estão munidas de redes de furos drenando a rocha".

A propósito de Malpasset TERZAGHI (1962) afirmou que o aci dente serviria "de uma maneira fundamental para descobrix um fator que, no passado, não recebeu a atensão que merecia".

No mesmo ano, 1959, o desastre iminente da barragem de Idbar (Tuguslávia) é interrompido por uma desscarga rápida da ägua do reservatōrio, através de uma brecha aberta com explosivos. A foto da figura 27 evidencia que as causas devem estar relacionadas com a percolação d'ãgua no maciço de apoio da ombreira direita.

E importante analisar as opiniões relativas a tais aciden tes, destacando-se por um lado aqueles que responsabilizam a fal ta de estudos mais aprofundados das fundações e, por outro, aque les que ressaltam a ocorrência de fenômenos até então desconhecí dos. Embora, uns e outros tenham sua parcela de razão, MELLo(1966) considerando não existir o "conhecimento completo" e, ao contrāriọ uma contínua evolução dos projetos, destaca a importância de as pectos que se localizam não no comportamento mëdio dos conjuntos obras $x$ meios fisicos mas nos seus comportamentos extremos ao "in cluir fatores especificos a cada local de barragem.

Em 1961, CASAGRANDE apresenta sua polêmica obra na "First Rankine Lecture": "Control of seepage through foundations and abut ments of dams". O autor analisa o comportamento de uma sērie de barragens do "Tennesee Valzey Authoroty" e do "Bureau of Reclamation". Nas figuras apresentadas em seu trabalho observa-se que os drenos eram relativamente rasos (de $10 \%$ a $20 \%$ da altura das barragens) quan do comparados às cortinas (cerca de $30 \%$ da altura das barragens). - próprio autor assinala que até então os drenos não se aprofundạ vam mais que 12 ou $15 \mathrm{~m}$. $\mathrm{E}$ de interesse reproduzir al 


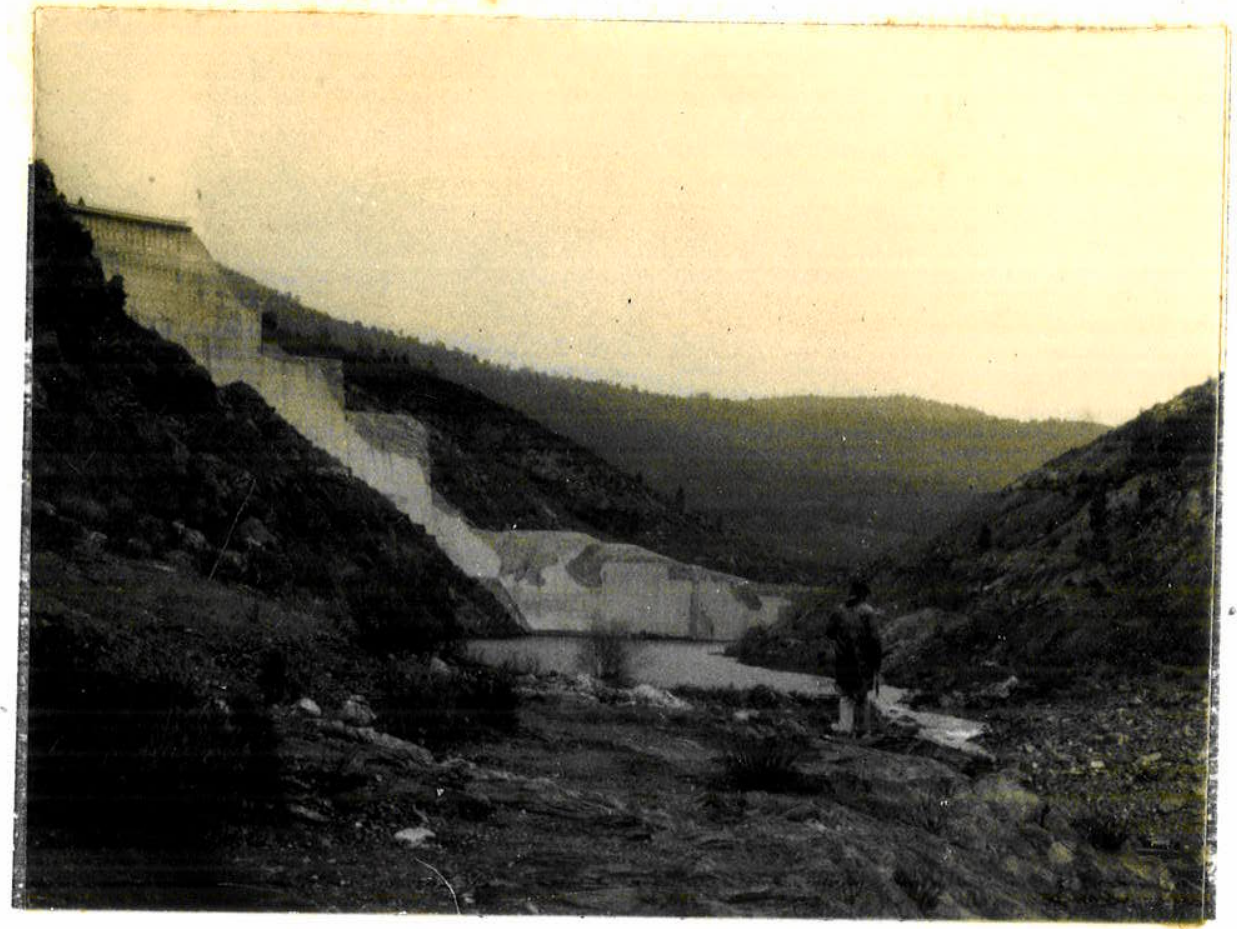

Figura 26 - Foto da barragem de Malpasset. Vista de jusante (09) $04 / 71)$.

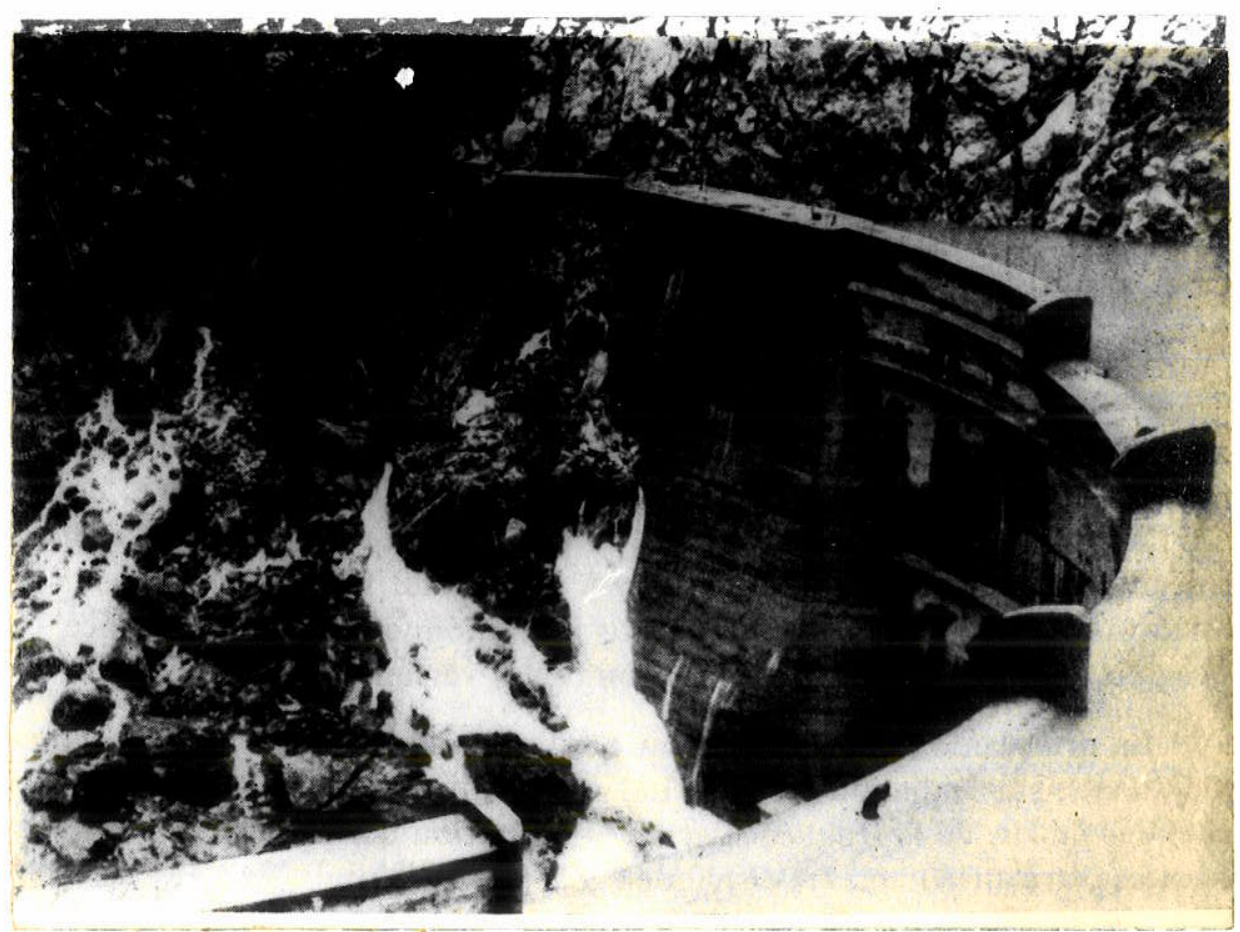

Figura 27 - Foto da barragem de Idbar. Início da ruptura da breira direita. (TALOBRE, 1967). 
guns trechos de seu trabalho:

"Notei, nos anos recentes, um aumento da crenga de que uma cortina de injegões formada por uma ünica linha de furos, pode ser ineficiente. Engenheiros chefes têm expressado a mim tais opiniões em particular, mas parecem reiutantes em manifesta-las publicamen te. Parece que temem atacar algo que é tido como dogma religioso, pela maioria, na profissão. Outros encobrem suas düvidas com decla racões tais como: "Consideramos a cortina de injeções muito segura. porém em nossos projetos confiamos apenas na drenagem".

Após comentar que a maioria das publicações dá grande ênfase as cortinas de vedação, prossegue: "Comparativamente, a discussão sobre os furos de drenagem é geralmente muito breve". "...tenho a impressão de que os arenos são tratados como enteados".

Realizando uma anālise teórica da eficiência de cortinas cons truidas com uma linha de furos, o autor verifica que pequenos "de feitos" da mesma, implicam numa eficiência extremamente reduzida das cortinas (figura 28). CASAGRANDE complementa esta análise com resultados de auscultação hidráulica e conclui que, na maioria dos casos, essa eficiência raramente excedeu a $30 \%$.

o autor levanta ainda problemas sérios relativos ao controle de percolação através de ombreiras de barragens em arco delgado chegando mesmo a condenar a construção de tal tipo de barragem "quando as condisões geológicas são de caráter tal que não podem assegurar um controle positivo das pressões da ägua na rocha, a ju sante da barragem".

As reações aos comentários de Casagrande não se fizeram espe rar. E elas vieram sobretudo da Europa, onde a técnica das inje ções foi criada e desenvolvida e onde residem importantes escritó rios de projeto de barragens em arco (SERAFIM, 1962;CAMBEFORT, 1964). Em 1967, LONDE e SABARLY compararam a anälise teórica da efí 

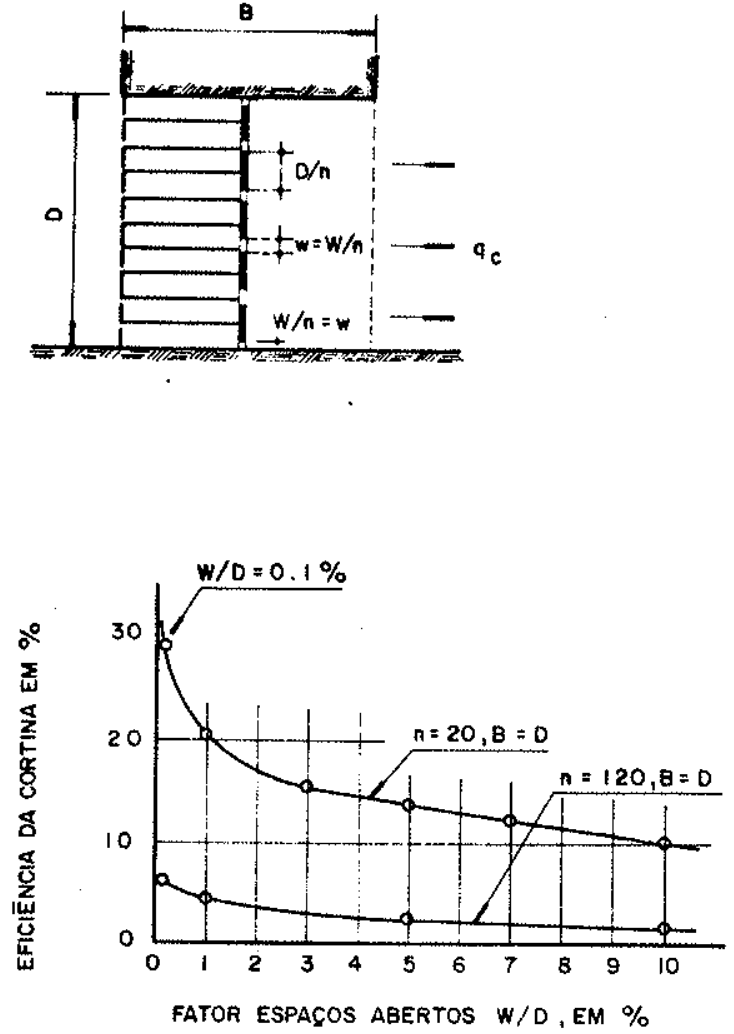

$$
E c=\frac{\ln \operatorname{sen} \frac{\pi w}{2 D}}{\ln \operatorname{sen} \frac{\pi w}{2 D}-\frac{n \pi B}{4 D}}
$$

$$
\begin{aligned}
& \text { SIMPLIFICANDO PARA W/O } \angle 0,1 \\
& (10 \% \text { DA CORTINA PERMANECE "ABERTA") } \\
& \qquad C=\frac{\operatorname{LOg} 10 \frac{2 D}{\pi W}}{\frac{n}{2.93} \cdot \frac{B}{D}+\log 10 \frac{2 D}{\pi W}}
\end{aligned}
$$

Figura 28 - Eficiência teōrica de cortinas imperfeitas (CASAGRANDE, 1961). 
ciência de cortinas, realizada por CASAGRANDE para meios continuos, com outra análise para meios descontinuos. A figura 29 apresenta os resultados da comparação concluindo os autores que, de fato, uma cortina de vedação não teria efeitos apreciáveis sobre a percola ção d'ãgua nas fundações, porēm desde que as fraturas fossem mui to finas.

SABARLY (1969) desenvolveu um extenso trabalho, ponderando as conclusões de CASAGRANDE: "Lee injections et les drainuges de jon dation de barrages en roches peu permeables". O autor, analisando um caso teórico de uma barragem fundada em terreno homogêneo permeável de grande profundidade e tratado por uma cortina de veda ção relativamente muito rasa, mostra que mesmo que esta cortina fosse perfeitamente estanque seus efeitos sobre as subpressões e vazões seriam praticamente nulos. Analisa também um caso teōrico em que foram realizados tratamentos superficiais de consolidação ou injeções de ligação concreto $x$ rocha em toda a base da barragem E conclui: "As tomadas de pressão piezométrica (no contato concre to $x$ rochal se encontram assim num terreno tratado de maneira mais ou menos homogênea e, neste terreno tratado, não hä nenhuma razão para que a cortina de vedaço crie uma descontinuidade. Tudo se passa nesta zona como se não houvesse cortina. Mas seria um pouco exagerado concluir que a cortina esteja mal feita e não seja es tanque".

Em 1970, LAA e FRANCO apresentam no 100 Congresso de Grandes Barragens uma comunicação a respeito do comportamento das funda ções de algumas barragens espanholas sem cortina de vedação. As barragens analisadas se encontravam na época em construção ou ti nham sido colocadas em operação desde 4 anos até um ano atrās. A pös considerarem o comportamento satisfatório das barragens obser vadas, propõem a revisão do critērio Lugeon, sugerindo adotar não 


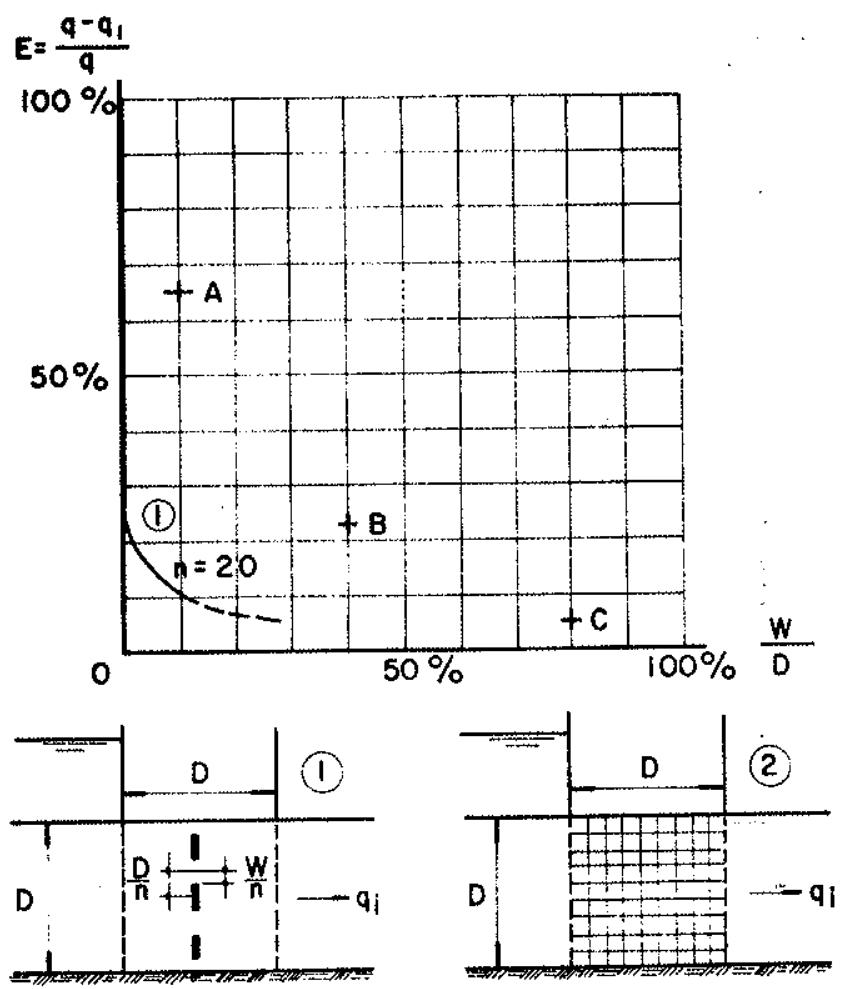

1) Meio poroso - cortina delgada (CASAGRANDE, 1961): Veja figura 28.

2) Meio fraturado - 10 fraturas

A - 1 fratura aberta - 9 fechadas

B - 4 fraturas abertas - 6 fechadas

C - 8 fraturas abertas - 2 fechadas

E - Eficiência da cortina

$q$ - Vazão anterior à injeção

qi-Vazão após a injeção

W/D- Coeficiente de abertura

Figura 29 - Análise teōrica da eficiência de cortinas (LONDE e SA BARLY, 1967) - 
10, mas $6 \mathrm{~kg} / \mathrm{cm}^{2}$ de pressão nos ensaios, de maneira a evitar a a bertura das fraturas ("claquage"). Sugerem ainda que seja sempre examinada a possibilidade de se evitar a cortina convencional de injeções, ao longo de todo o perímetro da barragem, executada pre viamente ao enchimento do reservatório:

Existem ainda numerosos outros trabalhos apresentados em Con gressos, cujo exame permitiria completar este breve apanhado histó riço. Contudo, as linhas gerais da evolução das tēcnicas de veda ção e drenagem, parecem estar aproximadamente traçadas. Uma destas linhas que parece estar bem clara é que, após o uso sistemâtico das cortinas até a década de 60, paralelamente à consideração do papel subestimado dos drenos, o meio tëcnico sofreu uma revolução dos conceitos em voga, passando a reavaliar mais detidamente o pa pel das duas técnicas de tratamento: vedação e drenagem.

No Brasil, o surto de implantação de grandes barragens de con creto se dả justamente nos anos 60. Estas barragens, na sua quase totalidade do tipo gravidade, foram projetadas por projetistas na cionais. E evidente o impacto, no meio técnico brasileiro das dis cussões sobre a questão, a nivel internacional los artigos de CÁSAGRANDE e de SABARLY foram traduzidos e divulgados respectiva mente 7 e 3 anos após as apresentações originais). Alguns trabą lhos publicados por autores nacionais refletem a preocupação em se analisar a questão. A título de exemplo podem ser citados: BoTE LHO (1966); CAMARGO (1969) e HSU, RE e ONO (1970).

No 20 Congresso Internacional de Geologia de Engenharia, rea lizado em São Paulo em 1974, os debates na Seção Técnica sobre o Tema VI (Geologia Aplicada a fundações de barragens) mostram que a questão ainda não foi sequer orientada de forma adequada para sua resolução: "Ontem, um inicio de controvérsia, amāvel e antiga, ocorreu não sö entre os membros do Painel, como entre certas pes 
soas da sala, sobre a velha história, que não está próxima de um acerto, da injegão e da drenagem nas fundagões de barragens e os respectivos papëis destas obras de seguranga" (SABARLY, 1974).

De um lado generalizações pouco úteis, de outro, a considera ção de que "cada local é um local", e o impasse continua: "No que concerne esta questão dos critérios geológicos que permitam a de finigão da drenagem de barragens, eu creio que é necessário resu mir as intervencões de ontem e de hoje, ressaltando que todos es tão de acordo em afirmar que a drenagem traz uma seguranga às $\underline{O}$ bras, seguranga esta que não é dada pelas injeções. Além disso, à questão colocada: existem critérios geológicos para a definição de uma rede de drenagem?, não houve ontem nem hoje respostas positi vas.... Eu espero, de minha parte, que se nös nos encontramos num vazio atualmente, quando de nosso próximo congresso daqui a qua tro anos, possamos responder mais positivamente que hoje" (BORDET, 1974).

MELLO (1974), en sua dissertação de mestrado, destaca a dificuldade em se examinar a questão. concluindo que as condições variáveis do meio físico de um lado e, de outro, a grande variabilidade das técriicas de injeção "tornam extremamente dificeis anălises teóricas confiāveis de injetabilidade de macisos rochosos" sugerindo assim a realização de ensaios prōprios de injeção no campo. Finalmente, levando em conta tais limitações, desaconselha a realização de ten tativas de normalização de critérios e procedimentos genéricos pa ra os trabalhos de injeção.

Finalmente cabe ressaltar que, de uma maneira geral, embora os autores tanto nacionais quanto internacionais, sejam unânimes em ressaltar a importância dos condicionantes geológicos na resolu ção da questão, é comum encontrar-se publicações sem destacar refe rências mais precisas sobre tais condicionantes. Em geral, as fi 
guras que ilustram tais trabalhos, apresentam muito bem a barragem a posição dos tratamentos e as linhas piezométricas medidas, mas, abaixo das fundações, não se apresentam detalhes, como se o meio natural não existisse.

\section{X. - CONCLUSÕES}

Os estudos teöricos das leis que comandam o fluxo d'ägua nas fraturas, apoiados em ensaios de laboratório, estendem ainda timi damente seus beneficios para a compreensão adequada do comportamen to hidrogeotécnico real dos maciços fraturados.

o estudo hidrogeotēcnico em modelos, cujo desenvolvimento re cente representa um avanço extraordinärio e promissor para a análi se dos problemas de percolação, apresenta um importante ponto frá gil definido por estreita depenđência do conhecimento do meio físi co natural, objeto da análise, uma vez que o desenvolvimento da caracterização hidrogeotécnica "in situ" dos maciços rochosos não tem acompanhado a evolução dos estudos teóricos do fluxo d'água em fraturas, nem dos modelos de análise.

A prática do projeto de barragens encontra-se ainda distante de um aproveitamento integral dos conhecimentos recentemente alcan çados. Os aspectos do projeto, relativos à percolação d'ägua, como vedação e drenagem, permanecem como assuntos controvertidos. Sus tenta esta situação, em boa parte, o desconhecimento do comporta mento hidrogeotécnico real dos maciços de fundação e a adoção sis temätica de regras de projeto tradicionais para o estabelecimento das hipóteses de subpressão e para a definição dos tratamentos. 


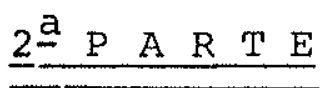

PROPOSTA DE METODOLOGIA 


\section{I. - INTRODUÇÃO}

As conclusões obtidas na 1 a Parte do estudo indicam que os es forços do meio técnico devem ser orientados no sentido de um me lhor conhecimento do comportamento hidrogeotécnico dos meios fra turados in situ para o projeto de barragens.

o fato da questão localizar-se no conhecimento do meio físi co natural, aplicado ao projeto de barragens, indica que a busca dessa orientação deve ter como referencial o conjunto meio físico $x$ barragem. A fundamentação deste referencial exige a adoção de uma base cientifica que pode ser oferecida pela Geologia. Esta proposi ção poderia parecer supérflua caso não se tivesse observado o esta do do conhecimento da questão, conforme foi feito na 1 a Parte e ca so não se observe a proposição feita através da curta história da Geologia Aplicada a barragens.

\section{II. - BREVES REFLEXÕES SOBRE A EVOLUCC̃̃O DA GEOLOGIA APLICADA} A BARRAGENS

De uma fase inicial, de importação e adaptação de conhecimen to de Geologia de Engenharia, desenvolvida sobretudo por. Pichler, no Instituto de pesquisas Tecnológicas, nos anos 40 e 50 , a Geolo gia Aplicada a barragens alcançou atualmente as condições para seu avanço significativo em termos de novos enfoques metodolögicos. Estas condições estão sendo criadas pela consolidação deste ramo do conhecimento aplicado e pelo amadurecimento das equipes que ne le vem atuando intensamente desde as décadas de 60 e 70 nos progra mas de implantação de grandes hidroelëtricas no sul e sudeste do pais. Com efeito, a experiência é significativa como pode ser ava liada, por exemplo, pelo número de trabalhos publicados em congres sos (GUIDICINI, 1976 ). 
O acúmulo de experiências deu-se pela conquista de espaços de aplicação da Geologia, desde as fases iniciais do projeto até a operação das barragens. Exemplificando, a prospecção geológica de eixos para a barragem de Barra Bonita, rio Tietê,CESP(1957/58) constitui um marco inicial nesta evolução (RUIZ, 1969). Na abertura da 2 a se mana Paulista de Geologia Aplicada em 1970, (RUIZ, 1970) traduzia a importância deste marco considerando que "ficou claro aos nossos técnicos, responsáveis por aquela obra, que a Geologia Aplicada de veria assumix papel de destaque nos estudos preliminares das gran des barragens que então se iniciavam no estado".

Se Barra Bonita constitui um marco para os estudos prelimina res, outras barragens vão em seguida representar o segundo salto da Geologia Aplicada na fase do projeto e construção. Nestas fa ses, onde podem ser destacados os estudos aplicados a Ilha Solteira, rio Paraná (CAMARGo, 1969), a Geologia foi aprofundada, ao nível de grande detalhe, no relacionamento das solicitações das barra gens com as caracteristicas geotēcnicas do meio físico.

Finalmente, a Geologia Aplicada galgou a última etapa de im plantação de barragens, ao atuar nas barragens em enchimento do réservatório e operação, sobretudo nos anos 70 .

A consolidação, no meio técnico, da Geologia de Engenharia foi traduzida pela realização do 2 Congresso Internacional de Geo logia de Engenharia no Brasil em 1974, marco significativo em sua história no país.

Referindo-se a esta fase de intensos trabalhos de Geologia em barragens, CAMARGo (1976) assinala que "para isto, os geólogos passaram a dedicar maior tempo de estudo a disciplinas da Engenha ria Civil, tais como mecânica dos solos, resistência dos materiais e materiais de construgão, em detrimento da Geologia propriamente dita".

Esta evolução exigiu portanto uma profunda especialização do 
geólogo em suas atıvidades junto à Engenharia Civil. Seu trabalho, seguindo a construção das obras, familiarizando-se com as exigên clas dos projetos de Engenharia Civil e acompanhando o desenvolvi mento da Mecânica das Rochas, produziu tendências importantes na forma de enfocar os problemas geotécnicos, o que se traduziu pela aplicação de metodologias de trabalho orientadas preferencialmente para a quantificąão das feições e fenōmenos geológicos. O exame dos maciços rochosos passava antes por uma ótica dos "Materiais" da Engenharia do que das "Formąões" da Geologia. O geólogo aprendeu a identificar as rochas e os maciços segundo regras empiricas tais como grau de alteração, de coerēncia e de fraturamento. Aprendeu a re duzir os maciços a classes I, II Ou III segundo tais caracteristi cas. Enfim, a construir as barragens, com os engenheiros. Procura va-se assim reduzir à distância que separava os trabalhos do geológo e do engenheiro nos problemas geotécnicos, como foi ca racterizada, por exemplo, por KANJI (1970). Em seu relato sobre o tema "Geologia de Barragens" na 2 a Semana Paulista de Geologia plicada, afirmava que "hã duas decadas atrás, as equipes de proje to de barragens utizizavam esporadicamente o servigo do geólogo, cujo raciocinio era essencialmente qualitativo".

No plano internacional, a evolução da Geologia de Engenharia experimentava tendência semelhante como se pode detectar nas preo cupações levantadas por JoHN (1974) ao analisar o 29 Congresso In ternacional de Geologia de Engenharia, realizado em são Paulo. Es tas preocupações envolviam justamente a tendēncia do geölogo em se distanciar demasiađamente da prōpria Geologia e concluía que este deveria estar firmemente embasado nas Ciências Geolögicas de ma neira a empregar plenamente, em seus trabalhos no campo da Engenha ria, todos os métodos do raciocínio geológico.

Em 1975, KANJI, no Informativo no 2 da $A B G E$, retomando esta 
anälise, assinala que a tenđência dos geológos julgarem a essência da Geologia de Engenharia sob um aspecto quantitativo, geraria o risco de subestimar o potencial da Geologia.

Embora seja difícil de precisar o quanto a consolidação da Geologia de Engenharia se deu à custa de uma perda, ou melhor, hi bernação de importantes vínculos com a prōpria Geologia, ē inegá vel que este fato alimentou a orientação de värios trabalhos de Geologia de Engenharia, segundo metodologias mais ou menos desvin culadas do raciocínio geológico. A transformação da Associação Pau lista em Associação Brasileira, em 1974, com a substituição da qua lificação da Geologia de Aplicada para de Engenharia poderia tal vez ser explicada, pelo menos em parte, por esse contexto. Pode-se relembrar que, na ëpoca, eram comuns discussões sobre o papel da Geologia nas obras civis, que refletiam um avanço firme da atuação do geólogo no campo da Engenharia. Desta maneira, embora se identi fique um certo afastamento da Geologia, o caminho percorrido nesta etapa foi o caminho necessário para a compreensão dos problemas geotécnicos impostos pelas barragens, para a compreensão dos proje tos e entendimento com os engenheiros-projetistas. Resulta ainda desta etapa um acervo de tēcnicas, criadas ou adaptadas e testadas nos vārios canteiros de obras, que constituem atualmente o instru mental bāsico de trabalho do geólogo de Engenharia.

Enfim, seguramente uma etapa foi vencida e o geólogo tem hoje um papel apreciável em todas as obras onde atua. A conquista deste papel e conseqtentemente de uma posição mais tranqlliza junto às equipes de projeto e construção de barragens, aliada a um signifi cativo acúmulo de experiências, durante todos estes anos, criou as condiçōes favorāveis para um novo avanço.

Valorizando as conquistas da etapa anterior, a Geologia de En genharia vem, com efeito, ganhando sua verdadeira dimensão, recupe rándo suas bases cientificas na própria Geologia. Segundo CAMARGo 
(1976), "passada a fase de afirmąão dos geólogos no meio de Enge nharia, estä sendo iniciado um movimento espontâneo, por parte dos geólogos que participaram dos primeiros passos da Geologia Aplica da, de retorno à ênfase em Geologia". Embora não se situe no campo de barragens, o trabalho de SAivTos(1976): "Por menos ensaios e ins trumentagões e por uma maior observação da naturezal apresentado no 18 Congresso Brasileiro de Geologia de Engenharia, reflete de manei ra clara as novas tendências.

Nas bases científicas oferecidas pela Geologia ressalta-se o raciocinio próprio a essa ciência caracterizado pela observação dos maciços naturais como Formąões, com gênese e história geológica definidas e sujeitas a uma certa evolução recente, na qual integra -se hoje o trabalho do homem. E o conhecimento do meio físico natu ral, eminentemente dinâmico, que permite assentar as bases funda mentais para a previsão do comportamento do conjunto obra x meio fí sico. Partem destas bases quaisquer metodologias de estudo que, lançando mão dos ganhos obtidos pela experiência (conhecimento das solicitações que a barragem exercerá no meio físico e acervo tecno lógico disponível para a quantificąão do meio físicol visem alcan çar essa previsão. De fato, a Geologia de Engenharia se realiza plenamente na previsão desse comportamento, etapa necessária e fun damental à realização dos projetos de Engenharia Civil.

A metodologia a ser proposta aflora destas reflexões e não só reforça as últimas tendências de evolução da Geologia de Engenhạ ria como retoma e aprofunda linhas de estudo de décadas passa das representadas especialmente pelos trabalhos do pioneiro Pichler. Este autor procurava definir diretrizes para os estudos geológicos de barragens baseando-se essencialmente nos diversos condicionantes geolōgicos impostos por tipos litológicos específi cos: basaltos, arenitos, granitos, etc (PICHLER, 1954). Outro exem plo, na mesma linha, è o trabalho de BARBOSA (1954). 
III. - A METODOLOGIA PROPOSTA

Sob o enfoque acima descrito, pode-se definir o referencial cientifico procurado, para uma melhor orientação dos estudos hidro geotēcnicos em barragens:

\section{MEIO EISICO}

- As unidades básicas do estudo do meio físico são definidas, em Geologia, co mo FORMAÇס̄ES

- As formações trazem em si uma histō ria geológica, traduzida em sua cons tituição Intima e estruturas.

- As rochas, que constituem as forma ções, estão submetidas a ações climā ticas, no espaço geogrä́ico de suas ocorrências, adquirindo comporta mentos hidrogeolögicos especificos.

\section{BARRAGEM}

- A construção de uma barragem altera drasticamente a evolução recente do meio fisico.

- Cada tipo de barragem introduz solici tações específicas ao meio físico.

O referencial cientifico assim definido, além de constituir um embasamento para as orientações gerais dos estudos hidrogeotéc nicos, corresponde à 1' cimento deste referencial, ou o desenvolvimento desta 1 a etapa da metodologia, exige o conhecimento atual da formação e do tipo de 
barragem, objetos de estudo, o que pode ser feito por um levanta mento da bibliografia e dos trabalhos técnitcos disponiveis sobre os dois lados da questão.

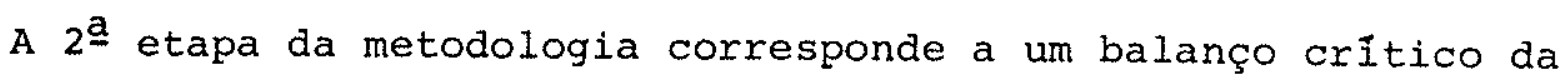
experiência acumulada em problemas similares. Similaridade esta de

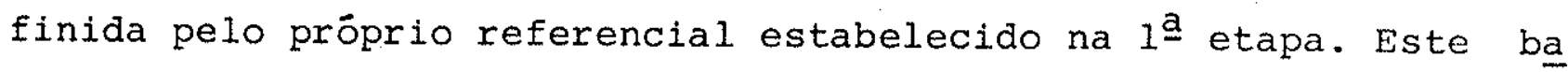
lanço pode ser realizado através de estudos de sintese dos dádos disponiveis das experiências anteriores, ou ensaios tipológicos. E necessário frizar que, embora a realização de tais estudos permi ta delinear comportamentos médios do conjunto obra $x$ meio físico, tais comportamentos não devem ser encarados dogmaticamente em sua transposição para sistemas similares em novos projetos. Vārios aú tores assinalaram, com efeito, o risco de se negligenciar os e feitos importantes de feições geolögicas secundārias em cada local (MELLO, 1966) mesmo desde longa data (TERZAGHI, 1929). A estes po der-se-imacrescentar os efeitos de detalhes de projeto exigidos por outros condicionantes que não geológicos (hidrāulicos, por e xemplo). Portanto, esta 2 a etapa, tem o objetivo principal de en riquecer o referencial cientifico anteriormente estabelecido, para orientar os estudos hidrogeotēcnicos.

A proposição de se desenvolver estudos de sintese assim rientados, encontra fundamento na própria necessidade de se acumu lar adequadamente as experiências em Geologia Aplicada. Com efeito, as formações constituem o referencial mais adequado para o acümulo dos conhecimentos sobre seus respectivos comportamentos geotécnicos.

Encontra ainda fundamento no diagnóstico sobre o desenvolvi mento da Engenharia de barragens no Brasil, realizado por FRENCISS (1972), em seu relato do VIII Seminärio Nacional de Grandes Barra gens, a partir da análise de uma amostragem de trabalhos, nacio nais e estrangeiros, publicados de 1920 a 1972 . Verificou o autor 
que a porcentagem de artigos estrangeiros crescia desde relatos de casos históricos até artigos sobre normas e metodologias de estudo, passando por uma porcentagem intermediária de trabalhos que faziam a sintese de problemas ou apresentavam ensaios tipológicos. Consi derou esta distribuição de fréqlência de artigos um sintoma normal da dinâmica do desenvolvimento tecnológico. Ou seja, numa fase ini cial, experiências individuais são relatadas como casos históricos Em seguida, seria tendência normal que tais experiências viessem a ser discutidas em ensaios tipológicos, desenvolvendo análises compara tivas dos métodos e técnicas, utilizadas nos vārios casos, sinteti zando em seguida, as experiências comuns. Esta revisão crîtica só então possibilitaria a definição de normas e metodologias de estuda O autor constatou, no entanto, que na amostragem de trabalhos bra sileiros não havia um número expressivo de estudos de síntese ou ensaiostipológicos, frente aos relatos de casos e às normas. o au tor conclui que esta situação anômala deveria provavelmente consti tuir "um reflexo de uma transposicão acritica de normas e metodo logias vigentes em vārios países, às necessidades brasizeiras". Con siderando a quase inexistência de tipologias referentes aos pro blemas nacionais aponta "a necessidade de mobilizap esforgos obje tivando a elaboração de apreciagões sintēticas de questões geológi cas aplicäveis às condigões brasileiras".

O esquema abaixo ilustra a metodologia proposta:

$$
\text { 1ㅡ ETAPA. } 2 \text { a } \text { ETAPA }
$$

Referencial Cientifico fnälise da Experiência

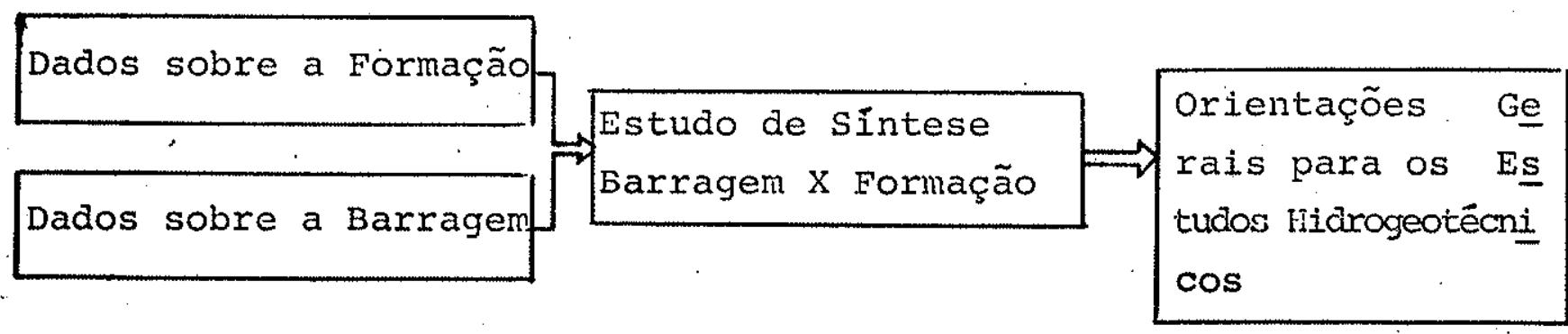


E importante frisar que esta metodologia não exige um aperfei çoamento maior ou uma sofisticação dos meios correntes de investi gação in situ. Este aperfeiçoamento, que vem se dando ao longo da história da Geologia de Engenharia, encontrará com a aplicação da metodologia, não só um estímulo mas sobretudo as condições mais fạ voräveis para produzir os melhores frutos.

Este enfoque metodológico não deve ser considerado, contudo, limitado aos estudos hidrogeotécnicos de um local de barragens. De ve-se considerar que mesmo a aplicação das leis teóricas de escoa mento requer o estabelecimento de um referencial como o proposto, no sentido de produzir resultados mais adequados à compreensão dos fenômenos tal como ocorrem na natureza. 
3ํㅡ P A R T E

APLICAÇÃO DA METODOLOGIA PROPOSTA 


\section{I. - INTRODUÇÃO}

A Geologia Aplicada a barragens, no Brasil, deve uma parte ponderāvel do seu desenvolvimento aos estudos realizados em várias barragens de gravidade sobre basaltos nas regiões sul e sudeste do paỉs. Este fato, que se traduziu num importante acúmulo de expe riências, sugere a aplicação da metodologia proposta, aos basaltos da Formação Serra Geral como fundações de barragens do tipo gravi dade.

o estudo do sistema Basaltos Serra Geral $x$ Barragens de Gravi dade tem sido objeto de desenvolvimento por parte de equipes do Instituto de Pesquisas Tecnológicas podendo-se citar OLIVEIRA, SILVA e GUIDICINI (1976) como um dos primeiros trabalhos de sinte se sobre o tema.

Recentemente foi realizado, sob a mesma ótica, um amplo estu do para a Companhia Energética do Estado de São paulo S.A. - CESP (IPT - Relatörio 12.513 - 1979). A realização deste estudo foi fundamental para o desenvolvimento deste capítulo da dissertação, que se encontra com plementado por dados de outras barragens, disponiveis na literatu ra técnica, e por dados relativos a estudos hidroyeolögicos visando a exploração dos recursos hỉdricos da Bacia do Paraná.

Deve-se ainda considerar que, a existência de uma série de barragens, em projeto e construção (figura 30) nas regiões sul e Sudeste do pais, justifica a escolha efetuada.

Entretanto; adverte-se que não se procurou aprofundar todos aspectos deológicos que estão a sequir levantados, mas ressaltar apenas aqueles que fossem relevantes para os estudos hidrogeotécnicos. 

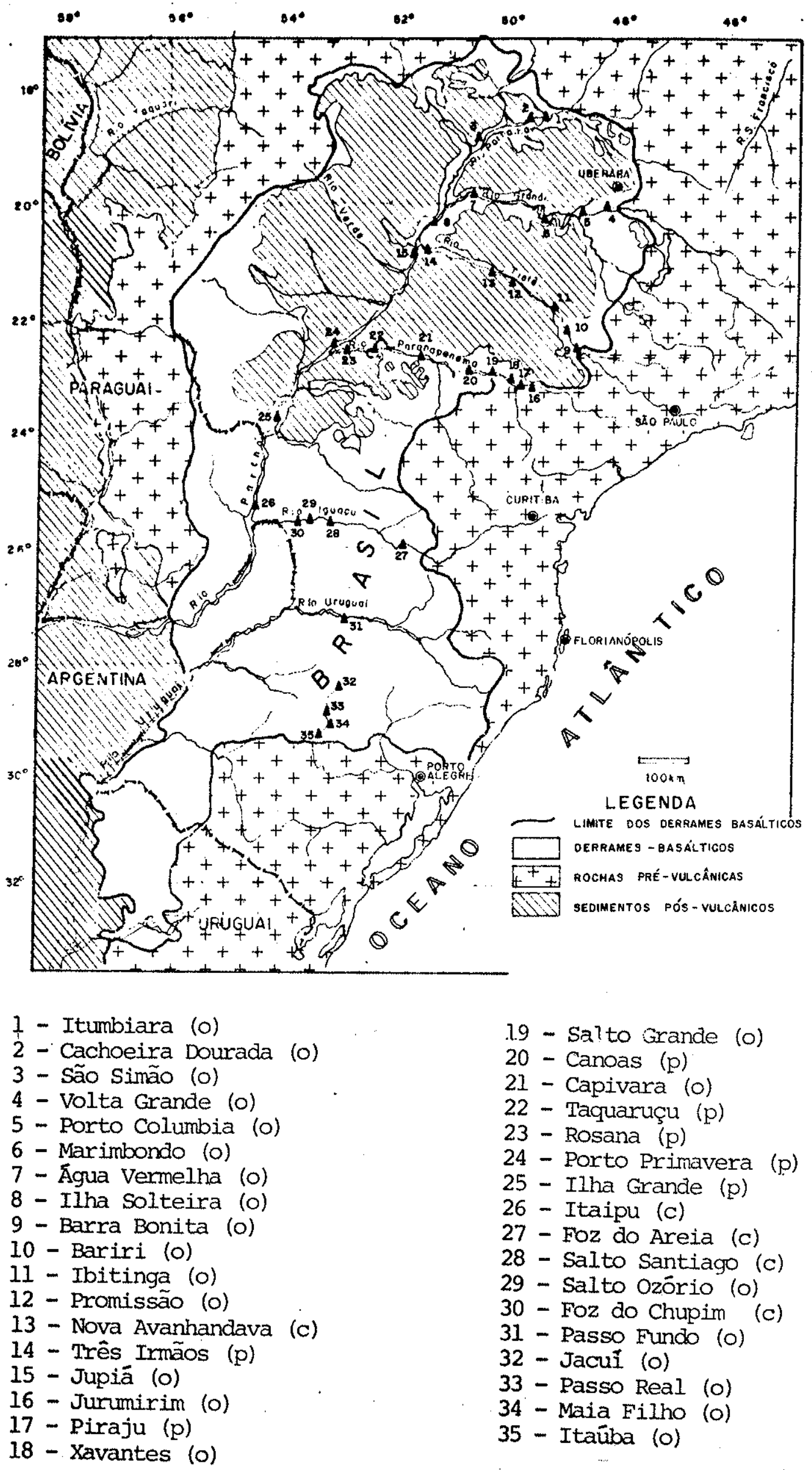

Figura 30 - Ocorrência dos derrames basálticos na bacia do Paranä (adaptado de AMARAL e outros, 1965) e principais barra gens em operação (o), construção (c) e projeto (p). 


\section{II. - OS BASALTOS DA FORMAÇÃO SERRA GERAL}

Visando determinar as caracteristicas hidrogeológicas princi pais desta Formação, são desenvolvidos neste capîtulo, como primei ro passo, os itens relativos aos aspectos geológicos condicionan tes, passando-se, em seguida, necessariamente, for uma identificação dos aspectos climāticos principais, e alguns aspectos geomorfolọ́i cos.

Os basaltos se estendem pelo sul e sudeste do pais numa exten são de cerca de I milhão de $\mathrm{km}^{2}$ (figura 30) e com uma espessura to tal que pode ultrapassar os $1.000 \mathrm{~m}$. Os basaltos são constituídos por um ma sucessão de derrames de espessura unitäria da ordem de alguns metros atē al gumas dezenas de metros que se encontram, frequlentemente, separados por sedimen tos intertrapeanos. Não existem dados sobre a extensão lateral dos derrames unitārios.

Formados por cierrames de lavas cretāceas, de idade mais fre quente de 140 milhões de anos ( AMARAL e outros, 1965), os basal tos constituem a Formação serra Geral que se encontra, na Bacia se dimentar do Paraná, cobrindo os arenitos da Formação Botucatu (Triássica) e coberta em parte (são Paulo, Minas, Goiás e Mato Gros so) pelos sedimentos Bauru (Cretáceo superior). Mais ao Sul da Bacia, nos estados do Rio Grande do Sul, Santa Catarina e paranä encontram-se, em geral, aflorantes.

\section{II.1. - Aspectos genēticos}

Embora não haja pretensão de se aprofundar a questão, ë importante considerar alguns aspectos genéticos dọs derrames basálticos e de suas estruturas singenéticas. Esta consideração tem uma importāncia inegāvel como em basamento das interpretações dos comportamentos hidrogeolögico e hidro 
geotêcnico dos basaltos, sobretudo quando comparada às gêneses de outras rochas cristalinas, em especial, as igneas intrusivas.

Os basaltos foram formados por extrusão de lavas, portanto à superficie da crosta. Os eventos de extrusão, intermitentes no tem po e no espaço da Bacia, originaram a superposição de vārios derra mes, estabelecendo assim o primeiro tipo de descontinuidade: os contatos entre derrames.

o escoamento de cada um dos derrames sobre a superfície, paulatinamente modificado pelo resfriamento, gerou a formação de descontinuidades internas, possivelmente traduzindo as diferentes vis cosidades da massa em escoamento, como sugerido por GUIDICINI e CAMPOS (1968).

O resfriamento progressivo da lava originou sistemas de fratu ras que, em värias ocorrências, se desenvolveram de forma regu lar originando estruturas típicas de colunamento.

Não se considerando as estruturas tectônicas, os fenômenos de escoamento e resfriamento à superfície podem, com efeito, ser considerados os principais responsāveis pela gênese das estruturas ba sálticas. Por outro lado, as rochas ígneas intrusivas, formadas no interior da crosta, apresentam descontinuidades, preponderantemente herdadas de regimes de esforços tectônicos, cujos padrões são ampliados pelo alívio de tensões, que se manifestam à medida que os corpos vão aflorando e sendo descobertos pela ação do intemperismo e da erosão.

Pode-se supor que, a grandes profundidades (värias centenas de metros), onde os basaltos apresentam descontinuidades com aberturas hi drogeologicamente expressivas, as descontinuidades das rochas intrusivas ainda não tenham atingido expressão equivalente, dado que ainda permanecem sujeitas a elevadas tensões. Esta consideração não implica em que não se observem efeitos de alívios de tensões em basaltos. De fato constatou-se em Vol 
ta Grande que as escavações permitiram que tais efeitos se pronun ciassem na abertura de um contato, anteriormente fechado e no deslocamento ao Iongo de "juntas-falhas" (BRITo, 1971). Alēm disso, alguns aspectos geomorfológicos ressaltam estes efeitos (veja item II. 5 a seguir).

A gênese de outras estruturas basálticos foi considerada em trabalhos tais como LEINZ (1949), GUIDICINI e CAMPOS (1969)

e OLIVEIRA (1969).

\section{II.2. - Constituição litolögica dos derrames}

Cada derrame unitārio tem uma espessura variável, com valores entre 5 e até $100 \mathrm{~m}$.

Em geral, em cada um pode-se caracterizar uma certa "estrati ficação", definida por uma alternância textural: os basaltos vesi culares (ou amigdaloidais) e os compactos. Aqueles ocorrem preferencialmente nas bordas do derrame, topo e base, sobretudo no topo (figura 31). O basalto compacto constitui a maior porção do mesmo, sob um topo vesicular (figuras 32 e 33). Esta "estratificacão",fica acentuada no pacote de derrames basálticos pela presença de arenitos ou siltitos intertrapeanos, que ocorrem em värios graus de coe rência ou compacidade: desde totalmente friáveis até extremamente resistentes (silicificados).

Finalmente, deve-se notar a presença de corpos litológicos, em alguns der rames, formados por blocos de basalto, em geral vesicular, imersos em matriz ar gilosa, siltosa, arenosa ou calcária,correntemente denominados de brechas. Quan do a matriz é constituida por outro basalto, a litologia tem sido conhecida por lava aglomerática. Tais corpos ocorrem predominantemente nos topos dos derrames.

\section{3 - Estruturas principais}

No pacote basältico ressaltam-se, imediatamente, os contatos entre os diversos derrames que o compöem. Descontinuidades de exten 


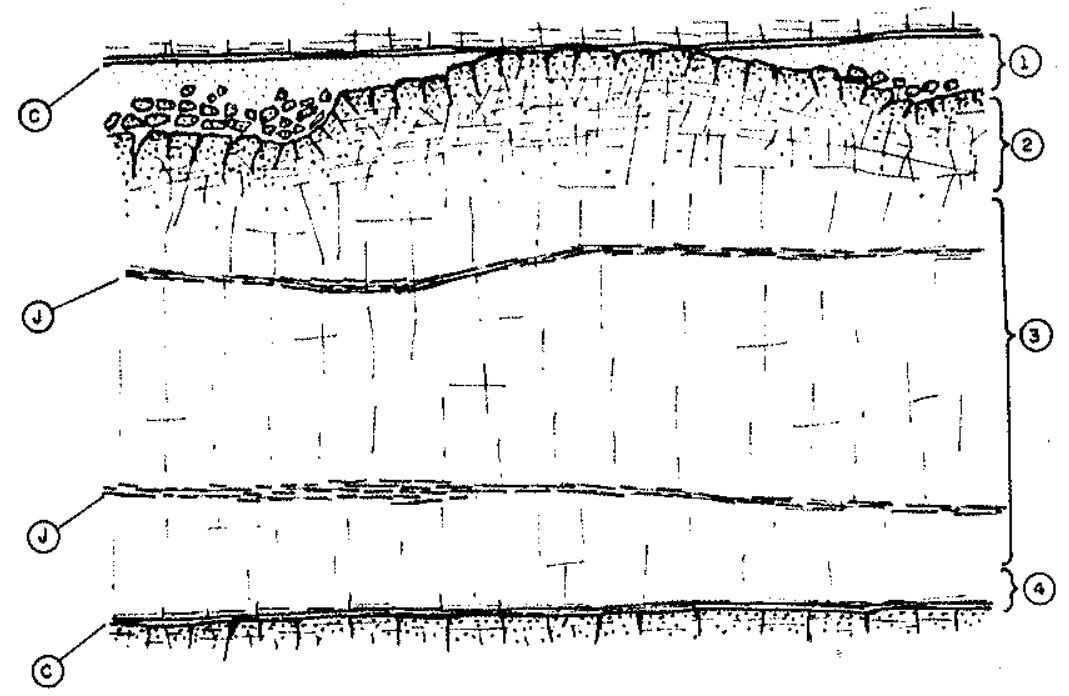

(1) Material intertrapeano eventualmente associa do a brechas, sob o contato (c) com o derra me superior.

(2) Zona do topo - basalto vesicular com fratu ramento horizontal predominante ou irregular.

(3) Zona do nūcleo - basalto compacto com fratul ramento vertical predominante (diaclasamento colunar). Ocorrência eventual de juntas de grande extensão lateral (j).

(4) Zona da base - eventualmente vesicular com fraturamento horizontal predominante, acima do contato (c) com o derrame inferior. 


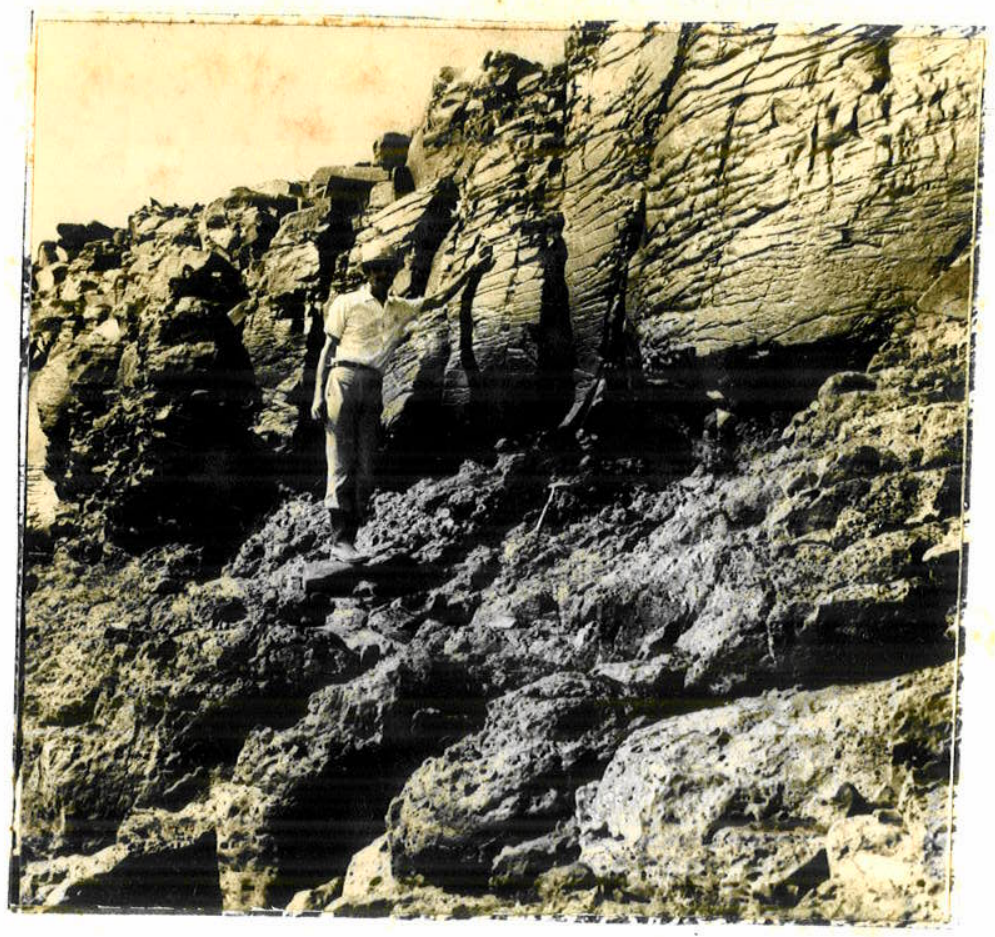

Figura 32 - Os dois tipos de basalto: compacto e vesicular (ou a migdaloidal), constituindo respectivamente, em Ilha sol teira, a base do derrame III e o topo do derrame II. Cá da um apresenta padrões diferentes de fraturamento (Câ nal no leito do rio Paraná, 1974).

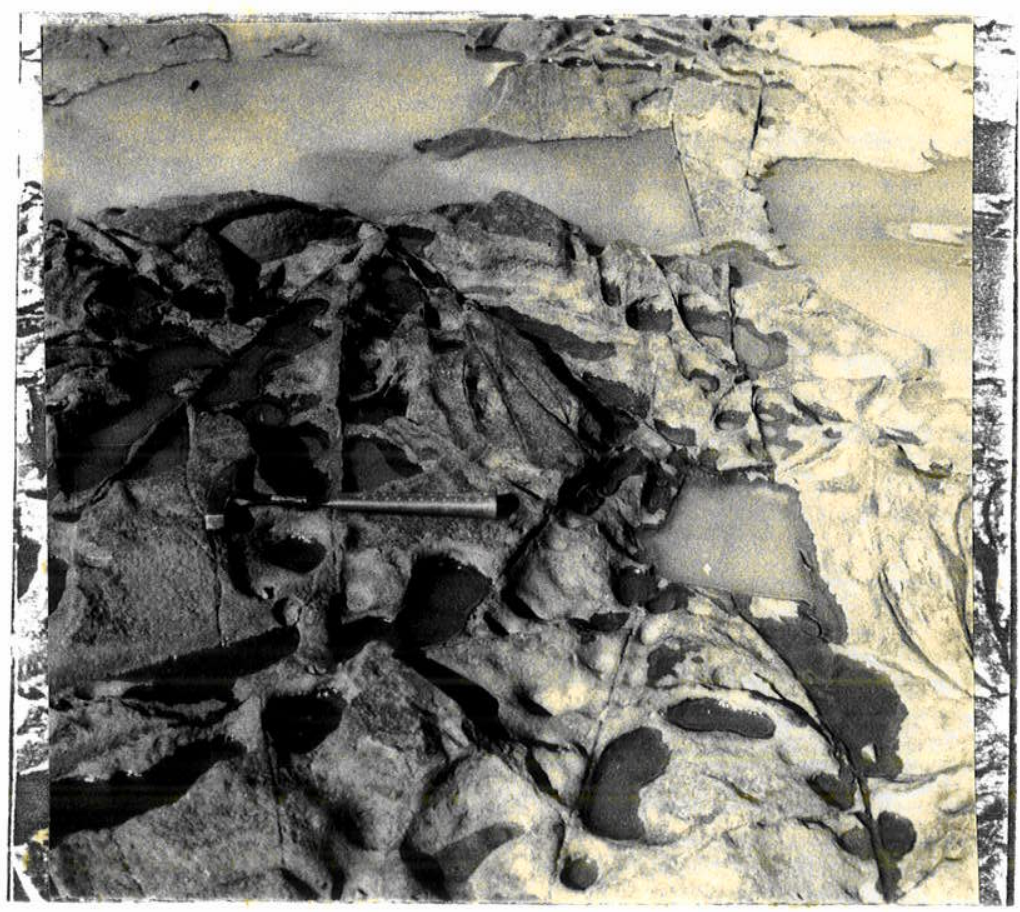

Figura 33 - Basalto compacto da figura anterior tal como ocorre na soleira do leito do rio Paraná. Observa-se o fraturamen to vertical. 
são lateral tão grande quanto a própria ocorrência dos

derrames, correspondem, em geral, a descontinuidades de grande abertura (de 0,1 a $3 \mathrm{~mm}$; podendo localmente alcançar até 3,0 ou mesmo $10,0 \mathrm{~cm}$ de abertura). Estas fendas podem se apresentar com ou sem preenchí mento argiloso (firura 34 ).

No interior de cada derrame o fraturamento segue, em geral, um pađrão típico, no qual se observa a tendência de suas bordas a presentarem um fraturamento horizontal embora, no topo, este se a presente muito mais irregular. O núcleo apresenta fraturamento preferen cialmente vertical (figura 35). As fraturas deste sistema se encontram, na grande maioria dos casos, preenchidas por materiais rígidos que têm sido identificados como sendo argilo-minerais montmoriloniti cos (nontronita) e calcita (SANTOS e RUIZ, 1963).

No corpo do derrame destacam-se, com certa frequência, faixas fraturadas de tão grande importância quanto os contatos e que fo ram denominadas juntas-falhas por GUIDICINI e CAMPOS (1968). Estas descontinuidades, observadas em vários locais de implantação de bar ragens, podem se estender por värias centenas de metros, acompanhan do aproximadamente os contatos e variando desde uma única fenda como em Ibitinga (GUIDICINI, OLIVEIRA e MATUOKA, 1974) até uma faixa extremamente fraturada, cuja espessura pode atingir de 1,0 a $2,0 \mathrm{~m}$. Estas juntas podem apresentar preenchimento calcário e ar giloso. Embora em sua maior extensão tenham um comportamento sub-horizontal apresentam, às vezes, brúscas mudanças de direção, mer gulhando em direção ạo topo ou base dos derrames, no espaço de de zenas de metros (figuras 36 e 37 ).

Alëm destas estruturas mais comuns, ocorrem outras que, por vezes, podem adquirir importância significativa no local considerado. são por exemplo, os derrames secundārios, ou subderrames, as trin cas ou cunhas, tubos, túneis e espiráculos (MOLER e CABRERA, 1976). 


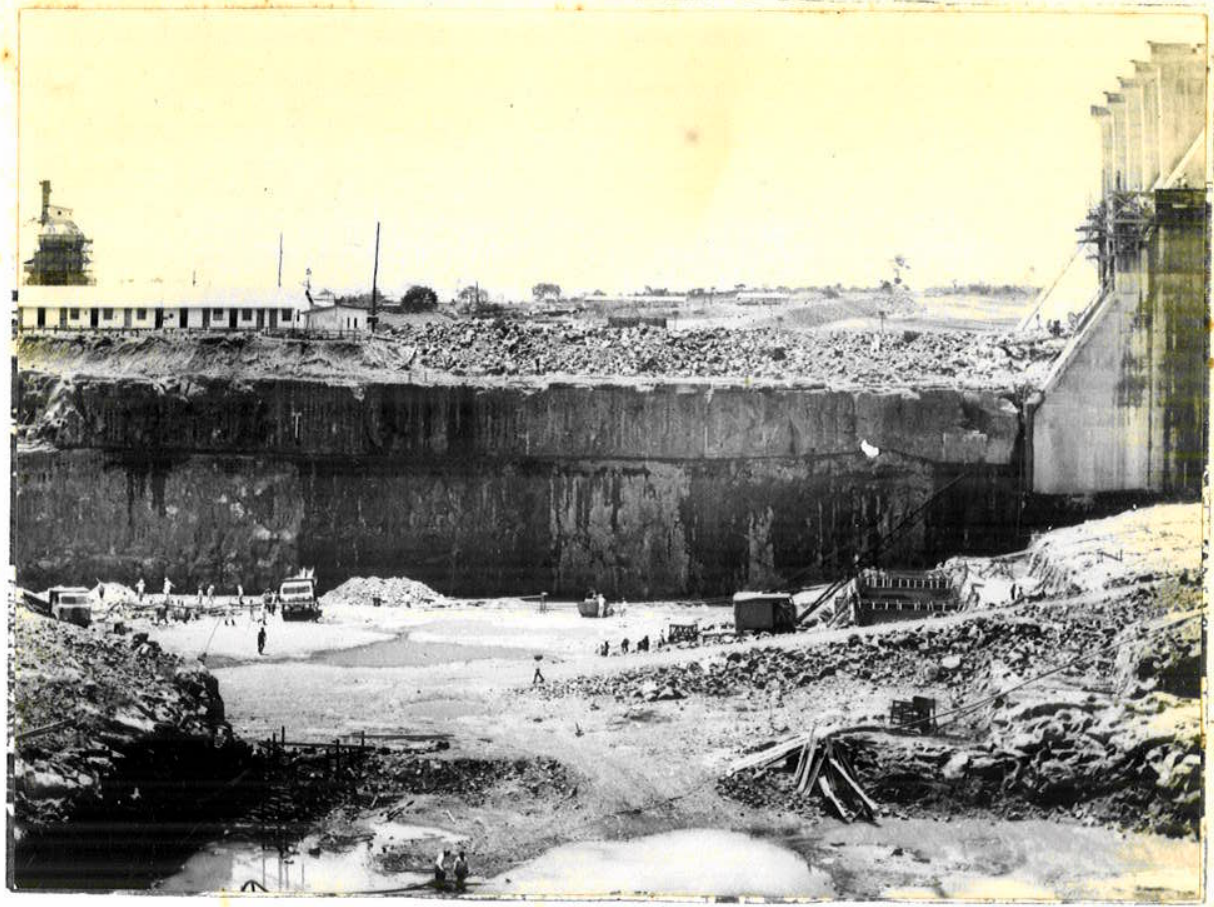

Figura 34 - Contato 348 entre dois derrames em Promissão. muro direito de ligação e escavações para os

Vista do res (1969).

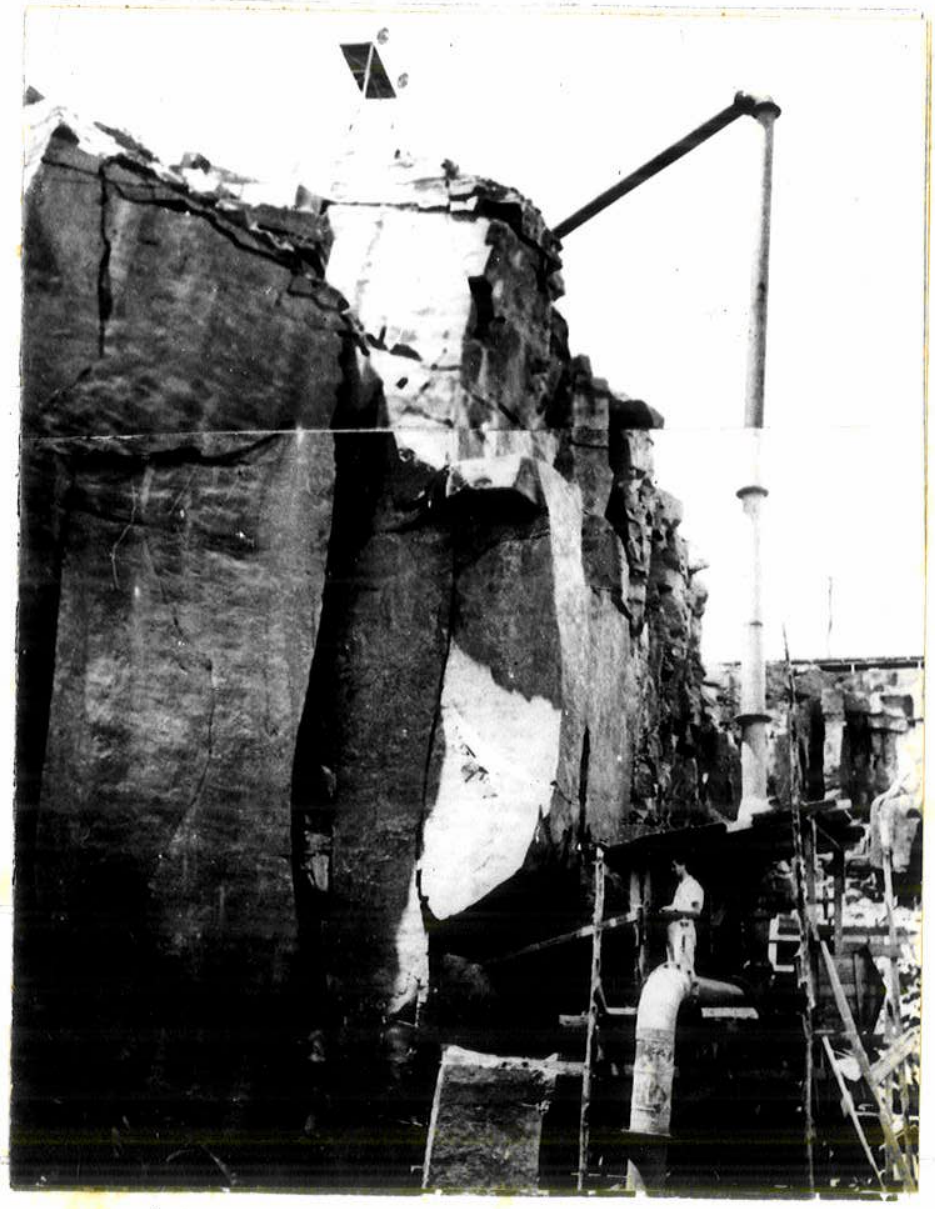

Figura 35 - Padrão de fraturamento em basalto compacto do núcleo do derrame principal de Ibitinga.: 


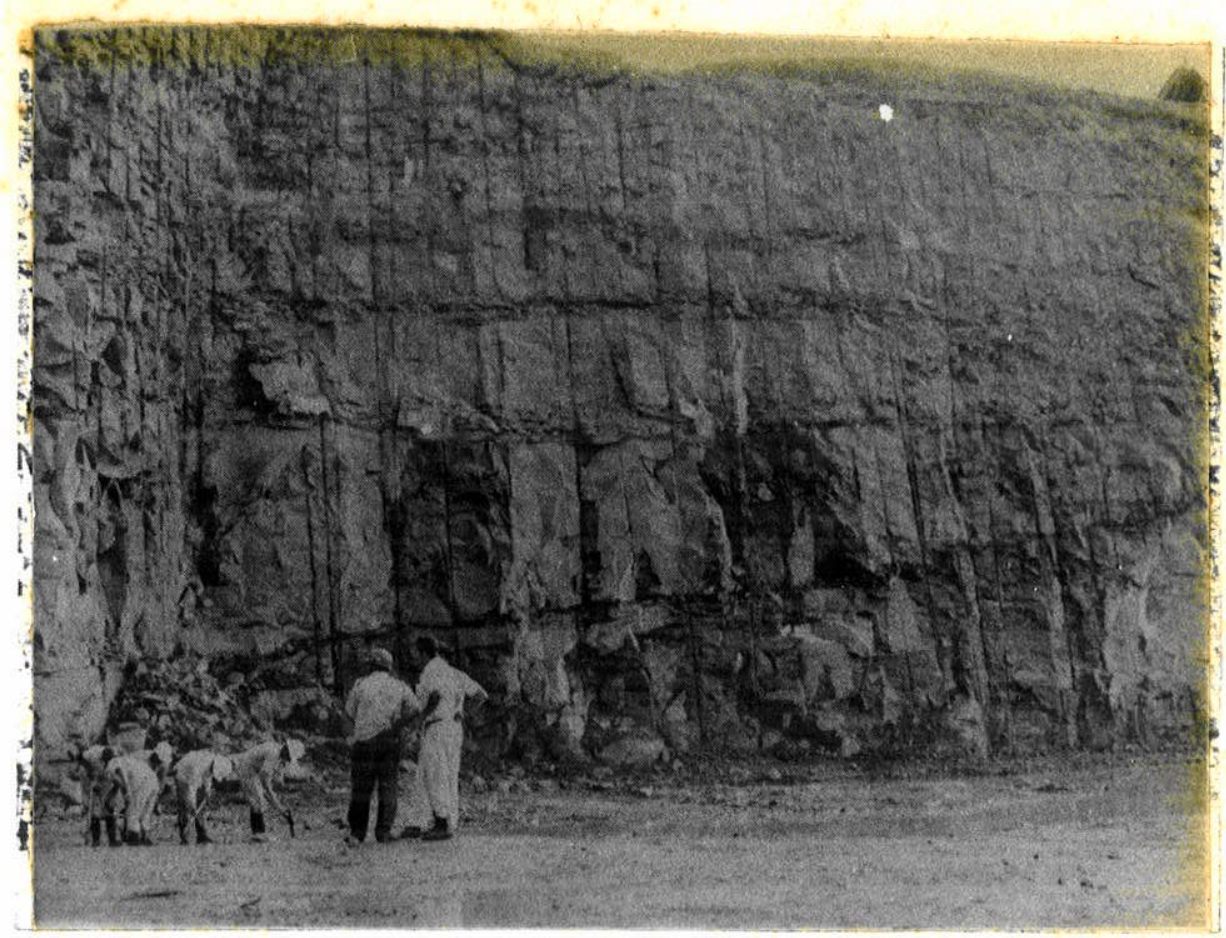

Figura 36 - Juntas-falhas ou faixas fraturadas na parede da escava ção para as tomadas d'água de Ilha Solteira (1969).

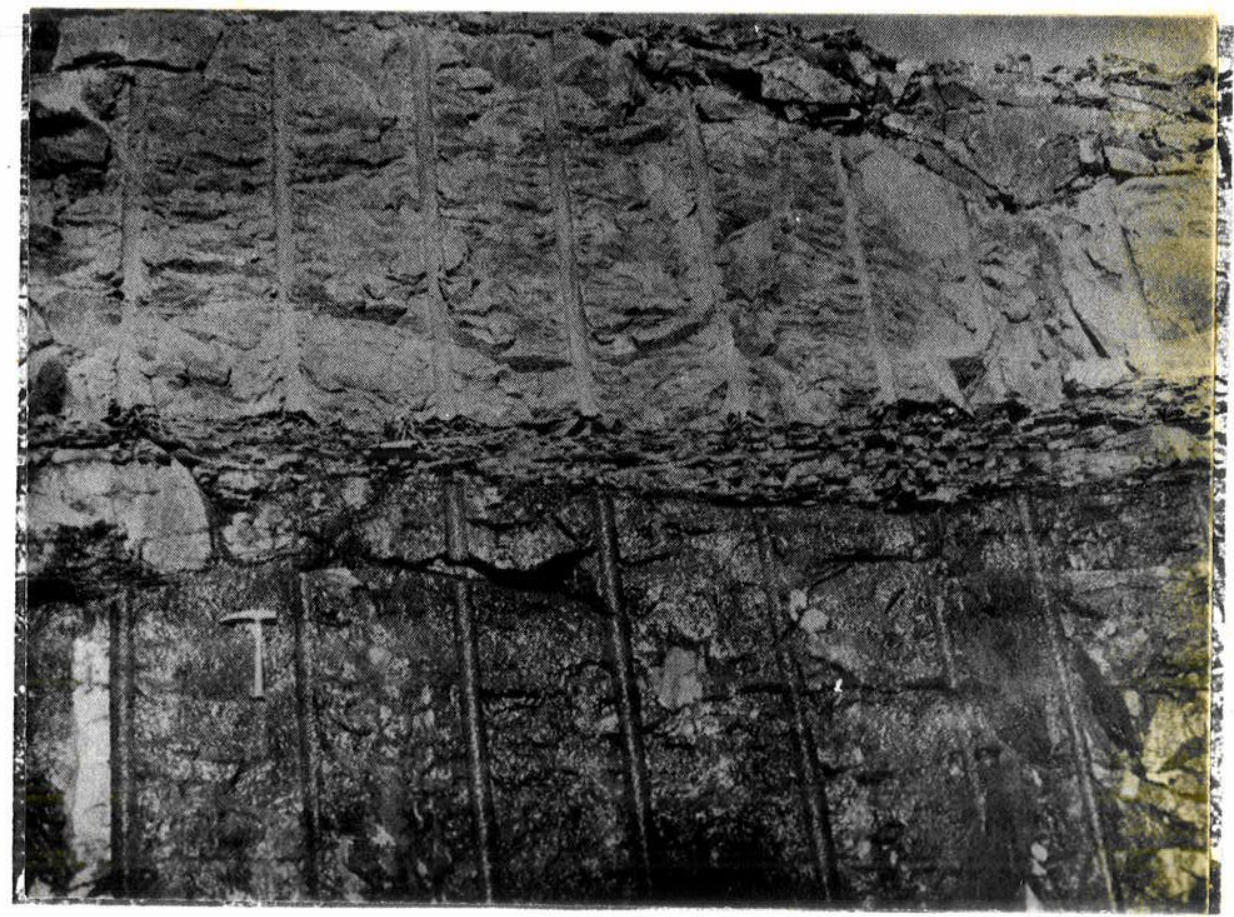

Figura 37 - Detalhe de uma junta-falha ou faixa fraturada d'água de Ilha Solteira, 1970). 
Uma representação esquemática de todas estas feições, juntamente com as já anteriormente citadas, se ocorressem num único derrame hipotētico, poderiam ser vistas como na figura 38 .

Superimpostos neste quadro geral de estruturas, podem ocorrer zonas fraturadas ou falhamentos regionais, associados ao tectonis mo da Bacia do Paraná. Tais fraturas ou falhas, identificadas por LEINZ (1949) como eixos tectônicos, vêm muitas vezes associadas a diques de diabásio e são, em geral, preenchidas por minerais secun dários. Nos locais de barragens construídas, contudo, raramente fo ram identificados falhamentos. Uma das exceções é Salto Santiago (rio Iguaçu). No estado de são Paulo, cujas barragens são objeto de análise mais detida nesta dissertação, não se tem evidência de qualquer perturbação tectônica, embora tenham sido estudadas as "estru turas circulares" de Ãgua Vermelha (ARAÚJO e outros, 1977). Sua o rigem, foi considerada pelos autores como condutos de lava. Estas estruturas , são formadas por vārias litologias (basaltos vesiculares, compactos , lavas aglomeráticas, brechas) complexamente distribuỉdas, e são fạ cilmente identificadas, em superfície, por sua forma circular. Seu papel no quadro hidrogeotécnico é importante pelo fato de cortar em profundidade vários derrames, e portanto suas principais estru turas subhorizontais.

\section{II.4. - Condições climáticas}

As caracterỉsticas geolōgicas por si só não determinam as propriedades hidrogeológicas das rochas. Estas serão definidas pela integração daquelas características com os condicionamentos cli máticos.

A Bacia do Paraná tem o seu clima definido, predominantemente pelo que se convencionou chamar de Frente Polar, isto é, segundo Monteiro (IBGE, 1963), a faixa planetāria de descontinuidade gera 

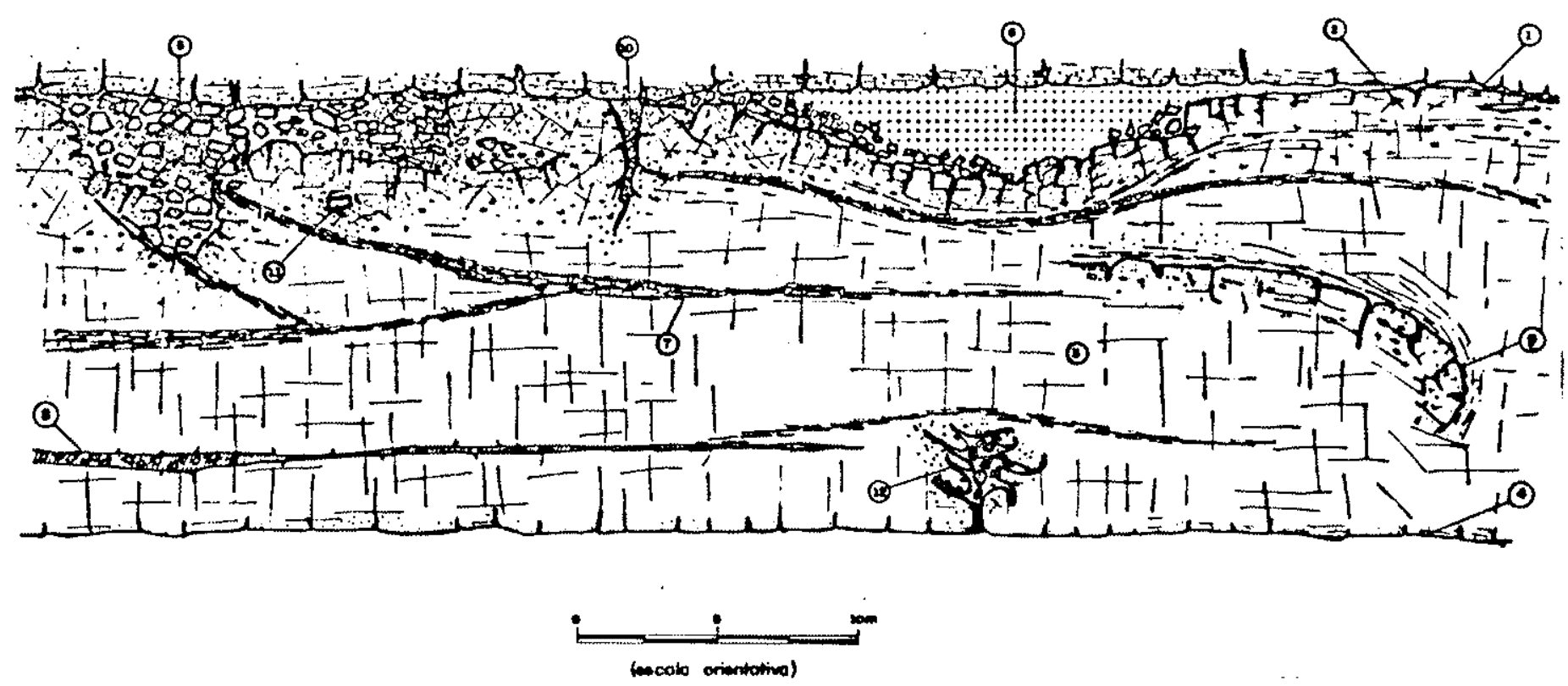

\section{1. - CONIATO ENTRE DERPAMES}

Fenda de abertura centímétrica de grande extensáo lateral. Fodét conter ou näo material de preenchimento (em geral argila). Nivel

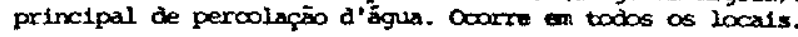

\section{2. - ZONA DE BASALTO VESTCULAR}

zona caracterlistica do topo do derrame. Fraturamento irregular. Zona com elevada parosidade vacuolar (fectada). Porosidade efe tiva baika. coorre en todos os localt.

\section{3. - zonA DE BasAlto compacto}

zona que constitui o núcleo do derrame, ocupando en médía 2/3 partes de sua espessura. Quando o derratre é delgado laté 8 a $12 \mathrm{~m}$ o fraturamento é via de regra irregular. Quando tern mals espessura (mais de 12 al $15 \mathrm{~m}$ ). O fraturamento ou melhar, dia clasamento, apresenta um padräo definido pela confugaçäo de uma familia harizontal com duas ou mais verticais que leva formacäo do columanento tipico. Estas diaclases que leva geralmente fectadas ou soldadas por matertais rígidos cono a calcita. A zana de basalto corpacto se comporta ocmo praticanen te "impermeävel" en relaçāo às estruturas que nela podén ocor rer (juntas-falinas, fajxas fraturadas, etc.). comorre en todos os locats.

\section{4. - zona DA BASE DO DERrRame}

Pode ser vesicular ou nĩo. Pode apresentar fraturamento soentus do, paralelamente do contato, podendo modguirir aspecto de ver dadeira leminapäo. Fraturas en geral soldadas por calcita. Ocor re en todos os locais.

\section{5. - zONAS DE BRECTA QU DE LAVA AGTOMERATTIO}

Cocrrem com maior fregtencia na zana do topo mas tambén podern o correr no nücleo do derrwe. Têm a formo de bolsōes ou lentes. Säo constituridas por fragmentos de basaltos, vesicallares ou compactos, ervoltos por matriz de natureza varlável que quali fica a brecta: argilosa, calcária, siltica. A matriz da lavia aglomerática é outro basal to que se diferencia dos blocos pela cor, textarra ou intersidade de vesfoulas. Quando al teradas pore

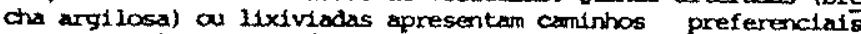

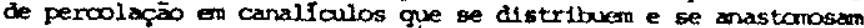
Irregularmente na zons. Ocorrem en Ilha solteira, Agru verme tha e Juptä, por exemplo.

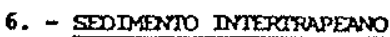

comorre entre un a outro derrame, na forma de lentes ou bolsōes, oun gramulacäo de argilla e arela- sendo o sil te o mais freqten te. Graus de compacidade ou cimentaç̃o (silicificaçä, em rai) variávels induzen porosidades tombern vartäveis. Doonre en vărlos locats.

\section{7. - FAIXAS FRATURADAS (OU "TUNTAS-FALHAS")}

Coarnem com grande extensio lateral (dezenas a centenas de tros) com atitude oub-horizontal. O fraturamento, no interiot das faixas destaca blocos de forma tabular miltas veres temt nando esm curnth e inturicados. Dm geral estes blocos apresents faces ol teradas ou coxidadas e peliculas argilosas. Podern as sociar a/ou constituir verdadeiras juntas-falhas. Representam no corpo do derrame, zonas de percolacäo preferencial. Ocomrero em vários locais.

\section{8. - JUNIA-FAI HA ("TMPO IBITINCA")}

Estrutura tão importante ou mais que os contatos no quadro ge ral de descontinuidades dos derrames, ocorre como uma verdadei ra falha de andamento sub-horimontal. A calis de falh ver pessura decimétrica è constituida por fragnertos angulosos de basal to. A matriz pode er argilosa ou calcarta. Constituif, geral, horizonte de franca percol lapäo d' agus. Iocal : Dbitinga.

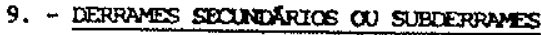

Estruturas de desagregação interna no derrame cum reabscarpōes parciais. Assocl adas a falsos contatos. Diferencla-se dos der rames principals pela peguena extens 50 lateral e por estantion praticamente englobados nestes. Poden constituilx horizon tes impartantes de peroolaçäo. Locais: Ilha Soltedra, sion sI

\section{0. - TRDNCAS, CUMFAS}

Estrutaras tipicas do topo de derrane podendo attugir alouns tros de profundidade e dezenas de metros de extensas. procontrom - preenchidas por material típico de brecta. Comportam-se como zonas de brectias. Locais: Volta Grande, Tropla.

\section{1. - TQWEer, TUBSO}

ocorrem na forma de cavidades lineanes ocm dezenas de metros o ertensiso e diämetro variável de centimétrico (tubo) e alguns tros (tánel). Locais: Cachoelra Dourada, Sä̃ simäo.

12. - ESPIRACUNO

Intrusōes jrregulares de material clästico. Local: São Simāo.

Figura 38 - Derrame h:́potētico apresentando suas principais feições litológicas e estruturas (Modificado de OLIVEIRA, SILVA e GUIDICINI, 1976). 
da pelo choque entre os sistemas intertropicais e polares. De ma neira simples, pode-se dizer que o comportamento desta Frente nas diversas estações do ano condiciona os diversos climas do Brasil Meridional. Enfim, ela è o principal fenômeno meteorológico da re gião.

Nos estados mais extremos do sul da região (Rio Grande do Sul, Santa Catarina e parte do Paraná) a influência da Frente se faz sentir durante praticamente todo o ano. Caracteriza-se essa região por um clima subtropical úmido sem estação seca. As precipitações médias chegam a ultrapassar $2.000 \mathrm{~mm}$ em vārias áreas dessa região (REBOUÇAS, 1976). Nas regiões mais setentrionais da Bacia ( norte do Paraná, oeste de são Paulo, sul de Goiās e de Minas Gerais, les te de Mato Grosso) jã se define uma estação seca que ocorre no in verno. As precipitações médias anuais vão de 1.000 a $1.600 \mathrm{~mm}$ (RE BOUÇAS, 1976).

De uma maneira geral, as infiltrações estão garantidas pelas chuvas abundantes que ocorrem na Bacia durante todo 0 ano, excetuando-se os meses secos das regiões setentrionais.Dado o cará ter mesotérmico da região, que leva a uma evaporação limitada por temperaturas não tão altas quanto no resto do país, e tendo em vis ta que as temperaturas mais elevadas do verão se contrapõem à incí dência de maior pluviosidade, Monteiro (em IBCE,1963) considera a re gião sul como a efetivamente mais ümida do país, configurando um quadro oposto ao da região nordestina.

Sob tais condições, a rede hidrográfica é rica, formada por rios perenes, com uma considerável descarga de base, mesmo durante os mais prolongados períodos de estiagem. Segundo REBOUÇAS (1976) este fato indica a presença de importantes fontes de recarga alia das às boas condições de armazenamento subterrâneo.

As coṇ̂ições climáticas, por outro lado, determinam o desen 
volvimento de processos intempéricos com certa predominância da de composição quỉmica dos basaltos. Esta alteração se desenvolve em profundidade seguindo sobretudo as principais estruturas dos derra mes. Este deve ser o caso das brechas argilosas da Ilha Solteira (argila como produto de alteração) e calcárias lixiviadas de Água Vermelha. E comum encontrar-se produtos de alteração na forma de argilas preenchendo descontinuidades.

\section{II.5. - Aspectos geomorfológicos}

o principal aspecto geomorfológico da Bacia está bem ressaltado no bloco diagrama elaborado por AB'SABER (1955) onde a configuração da Bacia em anfitea tro, com as Formações mergulhando em direção ao rio Paraná, tem grande importân cia no estabelecimento da circulação d'āgua subterrânea, na escala da Bacia.

$\mathrm{Na}$ escala dos aproveitamentos hidroelētricos existem noucas observações coletadas que possam ser correlacionadas a um quadro hidrogeológico natural. Com efeito, são raras as medidas piezométricas em contatos ou juntas do maciço ainda não perturbado pelas escavações, realizadas para a implantação de usinas.

Uma feição geomorfológica de interesse são as cachoeiras, comuns nos rios que atingem os basaltos. Tais feições tem reflexos importantes na circulação d'ägua no interior dos corpos basāiticos não só por constituirem uma forte con dição de contorno mas também por representarem um significativo alîvio de ten sões que permitiu o alargamento das descontinuidades prē-existentes (veja item II.6.5). A influência da cachoeira como condição de contorno foi observada em Agua Vermelha onde a carga piezométrica de um dos contatos, medida a montante da cachoeira dos Indios, apresentava-se mais controlada pelo nível. d'água de jusante da cachoeira, que pelo nível d'água local (IPT - Relatörio 12.513-1979).

GUIDICINI (1972) assinala outro aspecto identificado em lo cais de barragens como Capivara, Ilha Solteira e Agua Vermelha, re lativo à configuração das margens. Ombreiras salientes, remanescen tes do processo erosivo dos rios, apresentam descontinuidades 
mais abertas, favorecendo a ocorrência, de uma maneira geral, de permeabilidades mais elevadas.

Deve-se ainda assinalar a ocorrência eventual de canais pro fundos nos leitos dos rios, como o de Ilha solteira, que, cortando um ou mais derrames pode alimentar diretamente suas descontinuida des sub-horizontais mais importantes (CAMARGO, 1969).

Finalmente, ressalta-se um dos aspectos geomorfológicos mais importantes, tendo em vista não só a frequência com que ocorre,mas sobretudo suas implicações no comportamento hidrogeotēcnico dos ba saltos nas escavações e fundações de barragens. Este aspecto cor responde à ocorrência no leito dos rios, de soleiras constituídas por núcleos ou bases de derrames.

Sendo o basalto compacto uma das litologias mais resistentes à erosão, de quantas constituem a Formação serra Geral, è natu ral que persistam, nos leitos dos rios, restos de núcleos ou bases de derrames, protegendo litologias menos resistentes, que constituem a zo na do topo dos derrames inferiores. A espessura de bạ salto compacto remanescente no leito dos rios é variável: até 4,0 m em Ilha sol teira (figuras 32 e 34);5,0m em Jupiá; 7,0m em Promissão (figura 35); 10,0m em Bar ra Bonita e Capivara, e 10,0 a 20,0m em Moitinga. Esta configuração geomorfolögi ca tem grande importância na circulação d'água que se processa no maciço.

\section{II.6. - Caracteristicas hidráulicas principais}

Nos derrames, são as estruturas presentes que se comportam como aqui. feros, uma vez que a matriz é praticamente impermeável. O desenho da figura 38 apresenta as värias estruturàs condicionantes atravēs das quais ocorre, uma per colação d'água preferencial.

E de interesse analisar individualmente os parâmetros hidráulicos princi pais - porosidade e permeabilidade - para melhor entender o fenômeno da circula ção d'água nos basaltos. 
II.6.1. - Tipos de porosidade

E sem dúvida a porosidade de fratura o tipo de porosidade mais importante a ser considerado. Assinala-se a ocorrência de poro sidade intersticial praticamente só nos materiais intertrapeanos quando estes se encontram incoerentes. Mesmo a matriz basältica tem uma porosidade de microfraturas (FARJALLAT, 1975). Ocorre ainda a porosidade do tipo vacuolar nos basaltos vesiculares. Esta porosida de é fechada, ou seja, não apresenta intercomunicações, sendo ainda aqui preponderante a porosidade de fraturas. Identifica-se ainda, nas brechas ou conglomerados basälticos a porosidade de canais. Nes tas condições os canais encontram--se caoticamente distribuídos atra vēs da matriz, sugerindo que resultam de processos de dissolução ou remoção mecânica dessa matriz, pela percolação d'água.

II.6.2. - Permeabilidade

Nos horizontes mais pröximos da rocha sã, são as estruturas re liquiares, mais ou menos alteradas, as principais responsāveis pela percolação d'água. Ensaios realịzados em vários locais de barragem (Ăgua Vermelha, Capivara e Promissão) assinalam, como tendência a. uma maior permeabilidade, a zona do contato da rocha alterada com. - topo rochoso são (GUIDICINI, 1972).

No corpo dos derrames, destacam-se como estruturas muito per meáveis as estruturas horizontais de grande extensão como faixas fraturadas ou juntas-falhas e sobretudo os contatos entre derrames. A permeabilidade destas estruturas tende a ser a mais elevada dentro do derrame; estando em média entre $10^{-1}$ e $10^{-3} \mathrm{~cm} / \mathrm{s}$ mas atingindo frequentemente valores tais que, nos ensaios de perda d'água sob pressão, atinge o limite da capacidade de injeção da bomba, casos estes tambēm denominados de "perda total" da vazão da bomba. Em Promissão cerca de 35\% de to- 
dos ensaios executados nos contatos atingiram estes limites (OLIVEIRA e CORREA, 1976) enquanto que na junta-falha de Ibitinga a frequência destes casos foi de 308 dos ensaios (GUIDICINI, OLIVEIRA e MATUOKA, 1970). Ensaios com traçadores rea lizados en Ilha Solteira assinalam velocidades de percolação para um contato em torno de $10^{-1}$ com gradientes hidräuriticos entre $10^{-2}$ e $10^{-3}$ (SANCHEZ, GUIDICINI e SILVA, 1975). Em Promissão, ensaios do mesmo tipo assinalam permeabilidades, de um dos contatos, entre 10 e $100 \mathrm{~cm} / \mathrm{s}$ (IPT-Relatório 7.164 - 1973).

As estruturas verticais, diāclases de pequena extensão no cor po compacto do derrame tem, em geral, uma permeabilidade inferior a $10^{-5} \mathrm{~cm} / \mathrm{s}$. Tem-se observado que o fraturamento da rocha não deter -mina necessariamente a permeabilidade baixa ou alta do maciço. Mais importante è a ausência ou presença de materiais de preenchimento das fraturas. o exemplo típico é o maciço de fundação da barragem de Bariri que, apesar do alto Indice de fraturamento, é praticamen te impermeävel (RUIZ, 1963). Em Ilha Solteira, 646 ensaios de perda d'água sob pressão, realizados no maciço do basalto compacto, apre sentaram mais de $80 \%$ de seus resultados inferiores a $5.10^{-4} \mathrm{~cm} / \mathrm{s}$ e apenas cerca de 3\% com perda total da vazão da bomba (GUIDICINI, 1972). O autor considera que estes casos de alta permeabilidade po dem corresponder a juntas dẹ grande continuidade que não ' puderam ser identificadas.

As brechas basálticas apresentam permeabilidades extremamente variāveis dependendo sobretudo do tipo da matriz e do grau de alte ração. A brecha basāltica argilosa de Ilha Solteira (uma das mais potentes encontrádas nos derrames basálticos de fundação de barra gens) submetida a 583 ensaios de permeabilidade, sendo 266 por in filtração e 317 sob pressão, apresentou permeabilidades variāveis conforme mostra a tabela apresentada a seguir. 


\begin{tabular}{|l|c|c|c|c|}
\hline & \multicolumn{4}{|c|}{ PORCENTAGEM DE RESULTADOS NA BRECHA BASALTICA DE } \\
& ImHA SOLTEIRA \\
\cline { 2 - 5 } & Impermeáveis & $<.10^{-4} \mathrm{~cm} / \mathrm{s}$ & $\geqslant 5.10^{-4} \mathrm{~cm} / \mathrm{s}$ & "Perda tota1" \\
\hline $\begin{array}{l}\text { Ensaios de } \\
\text { infiltração }\end{array}$ & 27.1 & 32.3 & 40.6 & - \\
\hline $\begin{array}{l}\text { Ensaios de } \\
\text { perda d'agua } \\
\text { sob pressão }\end{array}$ & 4.4 & 22.7 & 62.7 & 10.2 \\
\hline
\end{tabular}

Tais ensaios envolveram também o basalto vesicular. contíguo (GUIDICINI, 1972). As diferenças encontradas entre os resultados dos tipos de ensaios são explicadas pelo autor pela possibilidade de ruptura da matriz argilosa quando os ensaios são realizados sob pres são.

Poucos são os dados existentes sobre a permeabilidade de ma teriais intertrapeanos. GUIDICINI (1972) apresenta valores entre $10^{-4}$ e $10^{-5} \mathrm{~cm} / \mathrm{s}$ para ensaios de permeabilidade em amostras dessa litologia em Jupiā, assinalando que a percolação d'água nos mesmos se dá preferencialmente por fratú ras.

As outras estruturas apresentadas na figura 38 (trincas ou cunhas, tüneis ou tubos, ect) podem, em certos locais, se constituir em horizontes ou caminhos preferenciais de percolação, mas faltam dados para caracterizä-los quanto à per meabilidade.

De maneira geral, portanto, dada a distribuição espacial das estruturas dos derrames, estes se caracterizam por uma forte anisotropia das permeabilida des. A permeabilidade no sentido horizontal tem se apresentado extremamente mais elevada que a vertical, sendo este um dos aspectos mais significativos dos basal tos quanto à permeabilidade. Éstruturas como as "circulares" (Água Vermelha) po dem se constituir em exceções. Estas estruturas têm uma permeabilidade horizon tal da ordem de $10^{-3} \mathrm{~cm} / \mathrm{s}$ podendo atingir até $10^{-2} \mathrm{~cm} / \mathrm{s}$ e uma permeabilidade ver tical que embora em geral inferior, pode alcançar localmente os mesmos valores (ARACUO E Outros, 1977).

A tabela no 5 apresenta dados de alguns locais de barragens. 


\begin{tabular}{|c|c|c|c|c|c|}
\hline 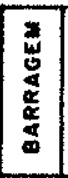 & 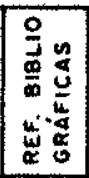 & $\begin{array}{l}\text { ESTRUTURA } \\
\text { OU ZONA OA } \\
\text { BARRAGEM }\end{array}$ & $\begin{array}{c}\text { FEICÁO LITOLÓGICA } \\
\text { OU } \\
\text { DESCONTINUIDADE }\end{array}$ & $\begin{array}{l}\text { VALORES MAIS FREQUEN } \\
\text { TES DE PERMEABILIOA- } \\
\text { DE EOUIVALENTE }\end{array}$ & OBSERVACÓES \\
\hline \multirow{2}{*}{$\begin{array}{l}\text { 票 } \\
0 \\
0 \\
0 \\
0 \\
0 \\
0 \\
0 \\
0\end{array}$} & \multirow{2}{*}{ (1) } & $\begin{array}{l}\text { borrogem de } \\
\text { lerra } \\
\text { (margem } \\
\text { direito) }\end{array}$ & $\begin{array}{l}\text { bosalio compocto } \\
\text { bosolto vesiculor } \\
\text { brecho bosáltico } \\
\text { contotos }\end{array}$ & $\begin{array}{l}4,7 \times 10^{-4} \mathrm{~cm} / \mathrm{s} \\
1,4 \times 10^{-4} \mathrm{~cm} / \mathrm{s} \\
6,0 \times 10^{-6} \mathrm{~cm} / \mathrm{s} \\
5,1 \times 10^{-4} \mathrm{~cm} / \mathrm{s}\end{array}$ & \multirow{2}{*}{-} \\
\hline & & $\begin{array}{l}\text { barrogem de } \\
\text { lerrolmargem } \\
\text { esquerda) }\end{array}$ & $\begin{array}{l}\text { basolto compocto } \\
\text { basalto vesicutor } \\
\text { contatos }\end{array}$ & $\begin{array}{l}1,5 \times 10^{-4} \mathrm{~cm} / \mathrm{s} \\
4,5 \times 10^{-5} \mathrm{~cm} / \mathrm{s} \\
9,0 \times 10^{-4} \mathrm{~cm} / \mathrm{s}\end{array}$ & \\
\hline 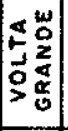 & (2) & $\begin{array}{l}\text { estruturos } \\
\text { de concreto }\end{array}$ & $\begin{array}{l}\text { contotos } \\
\text { junto- fotho }\end{array}$ & $\begin{array}{c}1,0 \quad 1 / \mathrm{min} / \mathrm{m} / 0 \mathrm{tm} \\
1,0 \circ 2,0 \quad 1 / \mathrm{min} / \mathrm{m} / 0 \mathrm{tm}\end{array}$ & $\begin{array}{l}\text { Volor médio } \\
1,0 \mathrm{l} / \mathrm{min} / \mathrm{m} / \mathrm{atm} \\
\approx 10^{-4} \mathrm{~cm} / \mathrm{s} .\end{array}$ \\
\hline $\begin{array}{ll}0 & 0 \\
5 & \frac{\pi}{x} \\
4 & 0 \\
4 & 0 \\
0 & 0\end{array}$ & $(3)$ & $\begin{array}{l}\text { barrogem de } \\
\text { enrocamento }\end{array}$ & bosolto compocto & $1,3 \circ 3,61 / \mathrm{min} / \mathrm{m} / \mathrm{otm}$ & $\begin{array}{l}\text { Volores de en } \\
\text { saios em furos } \\
\text { de costina de } \\
\text { injegóo }\end{array}$ \\
\hline$\frac{4}{3}$ & (4) & $\begin{array}{l}\text { fundogōes } \\
\text { em geral }\end{array}$ & nòo discriminodos & $\begin{array}{l}\text { entre } 1,6 \times 10^{-3} \\
\text { e } 3,3 \times 10^{-4} \mathrm{~cm} / \mathrm{s}\end{array}$ & - \\
\hline \multirow{3}{*}{ 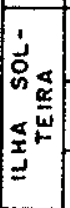 } & (5) & \multirow{2}{*}{$\begin{array}{l}\text { esteuturas } \\
\text { de concreto }\end{array}$} & $\begin{array}{l}\text { bosalto compocto } \\
\text { brecho bosáltica }\end{array}$ & $\leqslant 5 \times 10^{-4} \mathrm{~cm} / \mathrm{s}(*)$ & \multirow{3}{*}{$\begin{array}{l}\text { (*) com zonas } \\
\text { de médio } 15 \times \\
10^{-3} \text { o } 5 \times 10^{-4} \\
\mathrm{~cm} / \mathrm{s}\} \text { o olto per } \\
\text { meobilidode }(>5 \\
\times 10^{-4} \mathrm{~cm} /\end{array}$} \\
\hline & $(6)$ & & junto-fotho & $5 \times 10^{-3} \mathrm{~cm} / \mathrm{s}$ & \\
\hline & (7) & ecluso & contato & $1: 10 \mathrm{~cm} / \mathrm{s}$ & \\
\hline 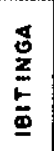 & (8) & $\begin{array}{l}\text { estruturas } \\
\text { de concreto }\end{array}$ & $\begin{array}{l}\text { bosalto compocto } \\
\text { contoto } \\
\text { junta-foltho }\end{array}$ & $\begin{array}{r}\leqslant 10^{-6} \mathrm{~cm} / \mathrm{s} \\
10^{-4} \mathrm{~cm} / \mathrm{s} \\
\geqslant 10^{-2} \mathrm{~cm} / \mathrm{s}\end{array}$ & 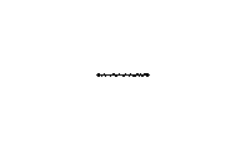 \\
\hline 童足 & $(9)$ & $\begin{array}{l}\text { esirutucos } \\
\text { de concreto }\end{array}$ & $\begin{array}{l}\text { bosaltos } \\
\text { contatos }\end{array}$ & $\begin{array}{l}\leqslant 10^{-6} \mathrm{~cm} / \mathrm{s} \\
\geqslant 10^{-2} \mathrm{~cm} / \mathrm{s}\end{array}$ & \\
\hline \multirow{2}{*}{ 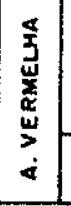 } & $\begin{array}{l}(10) \\
(11)\end{array}$ & $\begin{array}{l}\text { esteuturas } \\
\text { de concreto }\end{array}$ & $\begin{array}{l}\text { basalta } \\
\text { estrutura circular } \\
\text { contoto }\end{array}$ & $\begin{array}{c}10^{-5} \mathrm{~cm} / \mathrm{s} \\
\mathrm{K}_{\mathrm{h}}=10^{-3} \text { o } 10^{-2} \mathrm{~cm} / \mathrm{s}\end{array}$ & \multirow[t]{2}{*}{$(*) K v<K_{h}$} \\
\hline & $(12)$ & $\begin{array}{l}\text { ombreira } \\
\text { esquerda }\end{array}$ & $\operatorname{contoto}$ & $10^{-1} \cdot 10^{-2} \mathrm{~cm} / \mathrm{s}$ & \\
\hline
\end{tabular}

(1) BOURDEAUX e outros (1975)

(2) BRITO (1971)

(3) MARQUES FILHO e outros (1972)

(4) GUIDICINI E USSAMI (1969)

(5) CAMARGO (1969)

(6) NUSKE $(1970)$
(7) SANCHEZ, GUIDICINI E SILVA (1975)

(8) GUIDICINI OLIVEIRA E MATUOKA (1970)

(9) OLIVEIRA E CORREA FILHO (1976)

(10) ARAUNO e outros (1977)

(11) SILVA, ARAUJO E MONTICELI (1978)

(12) BJORNBERG, SANTOS E ZEFES (1980)

Tabela 5 - Valores de permeabilidade obtidos em vários locais de barragens (Modificado de OLIVEIRA, SILVA e GIUDICINI, 1976). 


\section{II.6.3. - Circulação}

Dadas as características acima levantadas, a circulação d'āgua nas rochas basālticas deve-se efetuar de maneira complexa, seja na escala do derrame ou da Bacia do Paraná.

Na escala da Bacia do Paraná o pacote basăltico assume o papel de confinante da Formação Botucatu e constitui a base impermeăvel ou substrato hidrogeológico do Arenito Bauru. Nesta escala pode-se conside rar como áreas de recarga dos aquíferos basálticos as áreas em que a. formação aflora.

Nas áreas cobertas por sedimentos pós-vulcânicos, os aquíferos Bauru podem eventualmente contribuir para a alimentação dos ba saltos, sobretudo nas bordas da Bacia. Finalmente, pode-se também considerar como uma possivel fonte de recarga as águas do arenito Botucatu, de baixo para cima, propiciada pelo importante artesianis mo que ocorre nesse arenito, especialmente nas proximidades do eixo da Bacia.

A alimentação deve ser feita preferencialmente através de con tatos aflorantes, juntas-falhas, etc. Em especial, deve-se conside rar as faixas fraturadas verticais (eixos tectônicos), falhas e es truturas como as "circulares" de Água Vermelha, alcançando diversos derrames.

Como zonas de descarga pode-se considerar as fontes naturais que ocorrem onde as interfaces solo superficial x rocha e conta tos entre derrames são interceptados pela topografia, em encostas ou vales. Em geral, estas fontes são periödicas e algumas vezes in termitentes. O comportamento periōdico destas fontes e de alguns po ços, pouco profundos, mostra caracteristicas de uma boa circulação nos basaltos, embora com baixo armazenamento (HAUSMAN, 1966). 
Na escala dos derrames, ou dos levantamentos geológicos em eixos de barragens, não existem praticamente dados relativos a zonas locais de carga e descarga dos maciços, quando ainda não peㅌ turbados pelas escavações. Constitui exceção Água Vermelha onde as estruturas circulares foram identificadas como importante zona de recarga ou alimentação do contato 315 (veja item IV.1).

No interior dos derrames a circulação se dá de forma essencialmente continua e concentrada nos contatos e juntas horizontais de grande extensão. Em vārios poços perfurados pela Petrobrás, apresentados por REBOUÇAS (1976) foram identificados os contatos como os principais responsáveis por abun dante produção de āgua, atē grandes profundidades, da ordem de vá rias centenas de metros no interior da formação. Os aquíferos que estas estruturas abrigam são mais ou menos independentes, conforme as juntas verticais que os interligam sejam, respectivamente, menos ou mais permeāveis. A execução de ensaios de bombeamento, dotados de observações piezométricas ao redor de poço central, revela niti damente este comportamento. Os ensaios realizados em Ilha Solteira, com efeito, mostram rebaixamentos imediatos em piezômetros coloca dos a mais de $100 \mathrm{~m}$ de distância (NUSKE, 1970). Assinala ainda o aú tọ casos em que piezômetros, mesmo a $10 \mathrm{~m}$ do poço, não apresentam qualquer reação ao bombeamento.

Assim, no interior do pacote, a sequência de derrames basáltí cos e suas estruturas, definem um sistema de aquíferos confinados, nos contatos e nas juntas sub-horizontais de grande extensão.

II.6.4. - Qualidade da āgua

Segundo HAUSMAN (1966), não existem particularidades que mar quem as propriedades das äguas que circulam nos basaltos. Contudo, - autor observa uma tendência maior para ãguas alcalinas que ãcidas e para maiores proporções de ferro que em äguas que percolam outras lito- 
logias. Aguas minerais, por vezes termais e radioativas, podem ocorrer associa das a estruturas tectônicas.

\section{II.6.5. - Caracteristicas mecânicas de interesse à Hidrogeotecnia}

Os basaltos da Formação Serra Geral têm sido submetidos a ensaios "in situ" e em laboratório, para se determinar suas características mecánicas com vis tas aos projetos das barragens. Contudo, como não tem sido feitas correlações entre seus comportamentos mecânicos e hidráulicos torna-se difícil apresentar algo mais que uma análise qualitativa e interpretações sujeitas a confirmação. O mesmo se passa na anälise do comportamento das fundações quando do enchimen to dos reservatörios, etapa esta que, embora propicia a correlações dessa or dem, tem sido pouco aproveitada nesse sentido.

Esta situação reflete provavelmente o fato de que as principais estrutu ras condicionantes da percolação nos basaltos não são tão sensíveis a tensões quanto as descontinuidades de maciços finamente fraturados. Com efeito, conta tos entre derrames com permeabilidades da ordem de dezenas de cm/s e significa tivas áreas de contato rocha x rocha, pouco seriam afetados pela construção de uma barragem tendo em conta o contraste com a baixa permeabilidade do restante do maciço. Provavelmente as estruturas basālticas hidraulicamente mais sensiveis sejam as faixas extremamente fraturadas de grande extensão, ou juntas -falhas.

Por outro lado, dadas suas caracteristicas genēticas, os basaltos não são tão sensĩveis ao alîvio de tensões quanto as rochas intrusivas. Contudo há au tores, como BJORNBERG e MEISMSTH (1975) que apontam o efeito do alivio de ten sões como significativo na peroolação d'água nos basaltos. Por outro lado, embo ra haja noticias de deformação de maciços quando submetidos a escavações, inter pretadas como resultado do alívio de tensões (BRITO, 1971), não hã dados relativos às implicações deste fenômeno nas suas caracterís ticas hidrāulićas. 
III. - AS BARRAGENS DO TIPO GRAVIDADE

De una maneira geral, värios aspectos sobre as solicitações impostas pelas barragens aos maciços jä foram apresentados na 1a parte (Capítulos VI e VII). A presenta-se agora os aspectos mais importantes de barragens do tipo gravidade, projetadas e construídas sobre basaltos da Formação Serra Geral. Foram relaciona das para tal, pela disponibilidade maior de dados, 7 barragens da CESP, cujas ca racterísticas estão apresentadas na tabela 6 . Sua localização pode ser identifi cada na figura 30, anteriormente apresentada.

\section{III.I. - Projeto}

Tbdas estas barragens tiveram uma concepção de projeto que procurou adaptálas às condiçães de meio físico do oeste do estado de são Paulo, das quais podese ressaltar a topografia suave, a morfologia aberta dos vales, a disponibilida de de solos para construção das barragens de terra e a presença dos basaltos, como fundação das barragens de concreto, no leito dos rios (figura 39).

As estruturas de concreto, condicionadas pela necessidade de instalação das casas de força e vertedores, são ligadas às barragens de terra por muros de liga ção. As casas de força, por exigências hidrāulicas, condicionaram profundas es cavações nos maciços basālticos.

Envolvendo especificamente o problema da percolação d'água nos maciços de fundação, nos projetos das barragens foram definidas as hipōteses de subpressão e os tratamentos, cortinas de vedação e drenagem.

III.1.1. Hỉpoteses de subpressão

Admitidas em cada um dos projetos, estas hipóteses resultam da adoção de critérios normalmente aceitos pelo meio técnico e semelhantes aqueles adotados pelo "Tennessee Valley Authority" (TVA) e pelo "US Bureau of Reclamation" (USBR). Segundo estes cri térios as subpressões, consideradas mäximas no pé de montante da barragem (carga total do reservatório) caem atē uma certa fração 


\begin{tabular}{|c|c|c|c|c|c|c|}
\hline BARRAGEM & $\begin{array}{l}\text { TERMINO DA } \\
\text { CONSTRUÇÃO }\end{array}$ & RIO & $\begin{array}{l}\text { ALTURA } \\
\text { MĀXIMA } \\
\text { (m) }\end{array}$ & $\begin{array}{l}\text { CAPACIDADE TOTAL } \\
\text { DO RESERVATORIO } \\
\left(10^{6} \mathrm{~m}^{3}\right)\end{array}$ & PROJETISTA & CONSTRUTOR \\
\hline Barra Bonita & 1963 & Tietê & 45 & 3116 & Techint & Tenco \\
\hline Jupiá & 1968 & Paranā & 62 & 3680 & Themag & Camargo Correa \\
\hline Ibitinga & 1969 & Tietê & 47 & 985 & Brasconsult & Tenco \\
\hline Ilha Solteira & 1973 & Paranā & 90 & 21200 & Themag & Camargo Correa \\
\hline Promissão & 1974 & Tietê & 59 & 7400 & Brasconsult & Tenco \\
\hline Capivara & 1978 & Paranapanema & 61 & 10500 & Engevix & CBPO \\
\hline Āgua Vermelha & 1978 & Grande & 90 & 11000 & Promon/Themag & Camargo Correa \\
\hline
\end{tabular}

Tabela 6 - Características principais das barragens analisadas, segundo o Registro Geral do Comitê Brasileiro de Grandes Barragens - Barragens da Companhia Energética de São Paulo s.A. 
da diferença entre os nỉveis de montante e jusante, na altura dos drenos. Desta posição, as subpressões alcançam o nível de jusante. Segundo CASAGRANDE (1961) o valor desta fração foi gradualmente re duzido nos ültimos 20 anos e é considerado, atualmente, 1/3 pelo USBR e $1 / 4$ pelo TVA. Esta redução sucessiva resultou da continua observa ção do comportamento real das subpressões. Desta forma os critē rios, aos poucos, deixam de ser conservadores para se ajustar me lhor às observações feitas.

Uma vez adotados, portanto, permitem traçar a linha de subpres sões, em seções típicas, transversais (modelos bidimensionais) às principais estruturas de concreto da barragem. Nestas seções trans versais, a linha do projeto corresponde às subpressões esperadas na base da barragem, ou seja, no contato da rocha com o concreto.

Admite-se que, em planos mais profundos das fundações, estabe leça-se uma configuração semelhante de subpressões. Para isto ado ta-se, como outra regra, a hipótese da existência de fendas verti cais de tração, ao longo do pé de montante da barragem, capazes de transmitir a totalidade da carga do reservatório àqueles planos.

Nas barragens sobre basalto, os critérios usados têm sido seme Ihantes.

Tais critērios, como já foi anteriormente abordado, são puramente geométri cos e genéricos, embora fundamentados na experiência de longos anos de observa ção. Ao serem estabelecidos en seções típicas transversais (modelos bidimensio nais) não levam em consideração nenhuma possibilidade de percolação d'água que não seja perpendicular ao eixo da barragem. Enquanto genëricos, não permitem con siderar as feições geolögicas que ocorrem na fundação.

No entanto, tais critérios se revestem de grande importância uma vez que as subpressões exercem papel significativo na estabili dade das estruturas e portanto no próprio dimensionamento da barra 
gem ou seja, no dimensionamento das estruturas de concreto (para a mesma altura da barragem) o que implica em volume de concreto e portanto decisão de ordem téc nico-econômica. Contudo, a existência de elevados graus de incerteza no comporta mento das percolações (chega-se, por exemplo, a considerar a hipótese de drenos inoperantes) leva a que se adote nos projetos, regras consagradas tradicionalmen te. As implicações da adoção destas hipöteses no dimensionamento e portanto no custo da obra, podem ser examinadas por exemplo no trabaho de CRUZ (1976).

Pode-se exemplificar a adoção de hipóteses com Ilha Solteira. segundo RE (1976) "Os cälculos de estabilidade mostraram que, em apenas um caso, os coeficientes de seguranga obtidos não se manti nham acima dos minimos previamente recomendados; era o caso do cál culo feito para a estabilidade na cota 252.0 da fundacão, na condi são chamada "cataströfica", ou seja, máximos nĩveis d'ägua a montan te e jusante (correspondentes à vazão decamilenar) e sistema de dre nagem completamente inoperante (diagrama de subpressão total). Para esta condigão os coeficientes de seguranca, respectivamente para os termos coesão e atrito da envoltöria de resistência. resultaram ser $\tau, 98$ e $\tau, 2^{\prime \prime}$.

Ao analisar barragens sobre condições semelhantes de fundação e destacando detalhes geolögicos secundários cujos efeitos podem ser relevantes sobre a éstabilidade de barragens, TERZAGHI conclui que "o simples fato da existência de normas de fundą̧ão so bre rocha, em geral relativos à intensidade do empuxo de baixo para cima, independente da estratificasão da rocha e independente também, do tipo de tratamento por injesão, indica perigosa tendêneia de ge neraliząão. O efeito consequlente é uma margem intoleravelmente am pla do fator de seguranģa das barragens com fundagão sobre rocha va riando entre pouco mais que a unidade e nümeros elevados".

"Como a maioria dos manuais não chama a atensão dos seus lei tores sobre a grande incerteza associada com as regras de projeto, 
baseado nesta prätica, muitos engenheiros empenhados em projetar barragens, têm um conceito muito exagerado dowgrau de confianga do método que empregam e, conseqllentemente, qualquer progresso neste campo se acha praticamente paralisado". O autor aponta ainda a sa da possivel para esse impasse: "O remédio para esta situagão indese jävel exige o abandono das regras padrões substituindo-as por re gras especificas, nas quais devem ser levadas em consideragão o ti po de fundagão e as caracteristicas geolögicas do local".

Recentemente, CRUZ e SILVA (1978) partindo de um enfoque se melhante ao do presente estudo, ou seja, analisando o comportamento real de barragens de gravidade sobre basaltos, propuseram novos critērios de projeto, que podem ser consideradas "regras especifi cas" tal como proposto por TERZAGHI (1929). Segundo estes novos critērios, a fração de queda de subpressões acima referida atingiria 1/5. Propuseram ainda uma certa queda nos valores de subpressão ao longo da hipotëtica fenda de tração. Embora tais propostas cons tituam um avanço significativo por considerarem essencialmente fun dações basälticas, não eliminam totalmente as crỉticas anteriormen te colocadas. Ou seja, os critérios ou regras de projeto, como tais, permanecerão sempre genéricos, por não poderem levar em consideração aspectos específicos tanto do projeto quando das feições basálticas de cada local de barragem, as relações destas feições com a obra, com o reservatório, etc. Além disso, permanecem restritas ao exame bidimensional da questão (seções transversais).

Tambēm recentemente as conclusões do Comitê da ASCE (American Society of Civil Engineen) apresentadas por RE (1976) sobre subpressão em barragnes de gravidade indicam a necessidade do estudo apurado das condições locais de cada casor alëm de afirmarem que as indicaçöes fornecidas não constituem regras a serem aceitas cegamente. 


\section{III.1.2. - Os tratamentos}

Os tratamentos, cortinas de vedação e drenagem, foram projeta dos com o intuito de controlar as percolações no sentido de garan tir as hipöteses de subpressão admitidas. Alguns projetistas res saltam no entanto certos papéis dos tratamentos que se complementa riam, segundo os quais a cortina teria basicamente a seu encargo a redução de vazões para os drenos, estes sim implantados para redu zir as subpressões (RE, 1976). Nas barragens analisadas as cortinas de vedação foram projetadas ao longo de todo o perimetro de montante das estru turas de concreto, seguida a poucos metros a jusante pela rede de drenagem. Somente as estruturas das tomadas d'ägua e casas de força fo ram envolvidas em todo seu perỉmetro pelos tratamentos, além da drenagem interna, devido a hipōteses de subpressão màis rígidas.

Assim, a extensão das cortinas de injeção tern resultado proporcional ao comprimento do eixo das barragens, nas estruturas de concreto, conforme a tabela apresentada a seguir.

\begin{tabular}{|l|c|c|c|}
\hline & $\begin{array}{c}\text { COMPRIMENTO DAS } \\
\text { ESTRUTURAS DE } \\
\text { CONCRETO (A) } \\
(\mathrm{m})\end{array}$ & $\begin{array}{c}\text { PERIMETRO DA } \\
\text { CORTINA (B) } \\
\text { Barra Bonita }\end{array}$ & $\begin{array}{c}\text { RELAÇ, } \\
(\mathrm{B} / \mathrm{A})\end{array}$ \\
\hline Ibitinga & 480 & 730 & 1,5 \\
\hline Jupiā & 545 & 720 & 1,3 \\
\hline Promissão & 1540 & 2140 & 1,4 \\
\hline Ilha Solteira & 400 & 626 & 1,5 \\
\hline Agua Vermelha & 1150 & 2000 & 2,5 \\
\hline
\end{tabular}

Foge um pouco aos valores encontrados, o caso de Água Vermelha 
onde os tratamentos cobrem praticamente todo o perimetro das estruturas de concreto.

Ao contrārio dos maciços intrusivos nos quais os tratamentos podem ser limitados em profundidade pela distribuição de permeabilidades dos mesmos, o comportamento hidrogeotécnico dos basaltos im plica numa certa dificuldade em se definir a profundidade ótima dos tratamentos. Nos basaltos, o aprofundamento excessivo dos tratamentos não só significa um gasto adicional na execução das injeçōes e drenagem como também resulta, no caso da drenagem, num encarecimento do sistema de esgotamento d'āgua das galerias, em geral feito por bombeamentio.

Nas barragens analisadas os tratamentos foram em geral projeta dos para interceptar as principais descontinuidades ou litologias problemäticas que ocorriam até certas profundidades. A definição das profundidades a serem alcançadas pelas cortinas de vedação e pe la drenagem resultou basicamente das análises de estabilidade efetuadas para cada uma dessas descontinuidades ou litologias problemá ticas. Análises semelhantes àquela relatada por RE (1976), apresen-. tada no item anterior, demonstraram ser desnecessário o tratamento de algumas descontinuidades e litologias. Por exemplo, a junta-falha em. Ibitinga foi injetada, porëm apenas drenada onde foi interceptada pelas escavações, na casa de força. O contato 230 de Ilha Solteira, 20 a $30 \mathrm{~m}$ abaixo das fun dações, não foi nen injetado, nem drenado. As profundidades de ocorrência destas estruturas eram no entanto compatíveis com as profundidades alcançadas pelos tratamentos em outras barragens, como pode ser visto na tabela 7 . Nesta tabela, as profundidades dos tratamentos e das descontinuidades estão referidas à altura do nivel d'água ( $\mathrm{H}_{\mathrm{NA}}$ ) do reservatörio (profundidades I das injeções de vedação, D da drenagem e J das descontinuidades), e com a altura do 


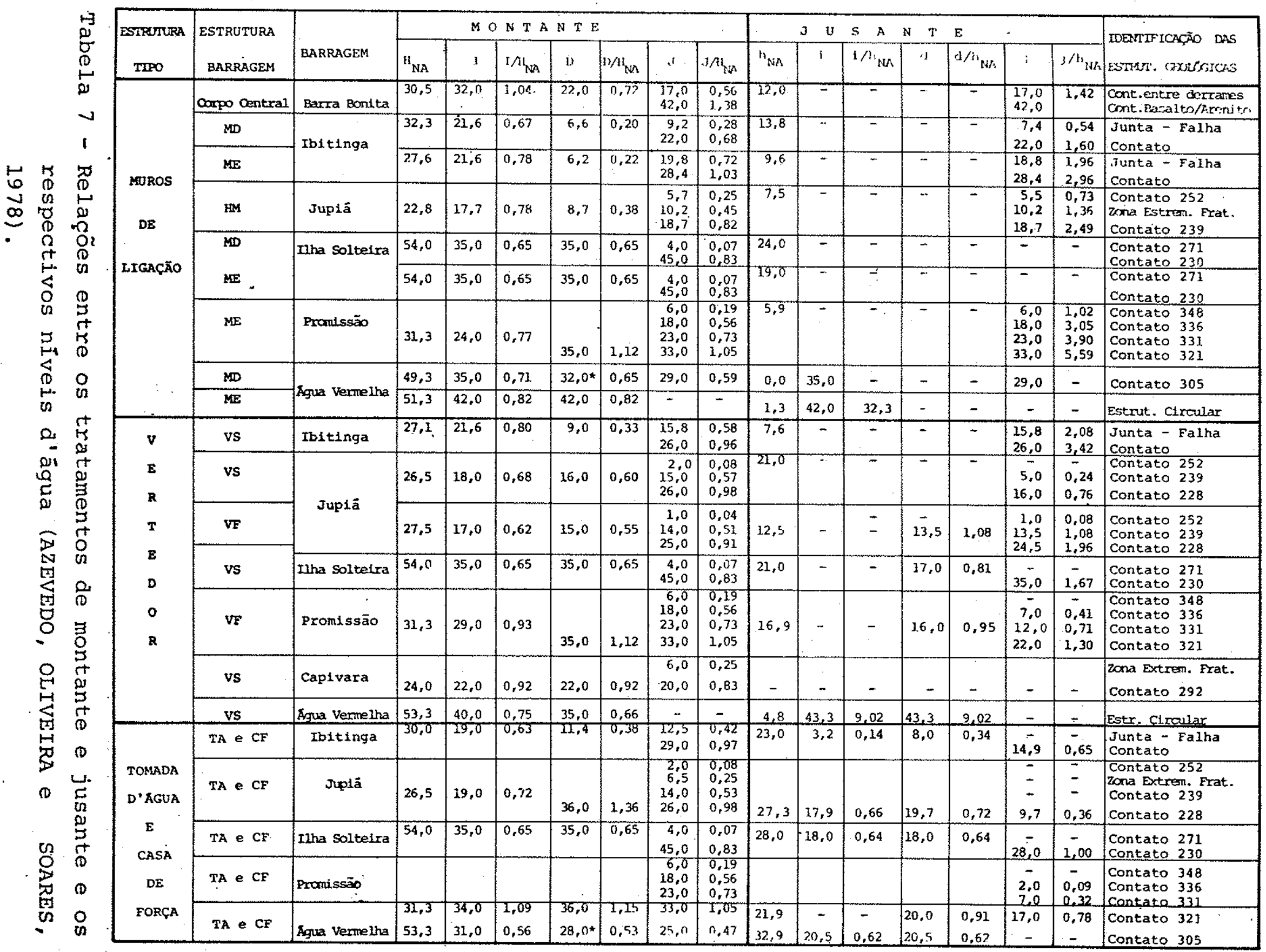

Iegenda.

HA - altura do gua do reservatō rio

$h_{\text {KA }}$ - altura do givel de ju gua de ju

I ou 1 - profun didade da cor

de in-

D ou d - profun profiun da dre J a j j - profom didade da des monti- 
nỉvel d'ägua ( $h_{N A}$ ) de jusante (profundidades i das injeções de veda Ção, d da drenagem e j das descontinuidades).

A profundidade das cortinas de montante variou entre cerca de 60 e $100 \%$ da altura d'ägua do reservatório, com valores mais fre quentes de 70\%. A drenagem foi em geral mais rasa, em relação à pro fundidade da cortina, nas obras mais antigas (Barra Bonita, Ibitinga e Jupià). A profundidade da drenagem tende a se igualar à da corti na nas obras mais recentes de Ilha Solteira, Capivara e Agua Verme tha e a ultrapassá-la em Promissão.

No interior das estruturas da casa de força a drenagem è bastante intensa, compreendendo furos executados a partir das galerias intermediärias e transver sais. Cumpre ainda ressaltar o projeto da drenagem superficial constituída por meias-canas dispostas entre o concreto e a rocha, cujos efeitos na drenagem ge ral das fundações são intensos.

Finalmente, embora não realizadas com o mesmo objetivo das cortinas, as in jeções de consolidação, eventualmente projetadas e executadas, acabam por provo car efeitos semelhantes na percolação d'água.

\section{III.2. - Construção}

$\mathrm{Na}$ fase de construção das barragens podem ser identificadas etapas significativas quanto às suas implicações nas condições hidrogeotécnicas do 1o cal. No capitulo VI da l. a Parte da dissertação, o assunto jă foi a bordado, destacando-se, até o enchimento do reservatório, 3 etapas principais: construção de ensecadeiras e desvio do rio, escavaçöes e concretagem.

Numa primeira etapa, a construção das ensecadejras objetivou basicamente a implantação das estruturas de concreto, através das quais o rio foi dostriado en fase posterior (fiqura 39). No interior da área ensuadn fo ram inicialmente executadas as escavações. A foto da figura 4i apre senta o exemplo de promissão. São evidentes as implicações destas etapas nas condições locais de percolação. E mesmo regionais, pois 


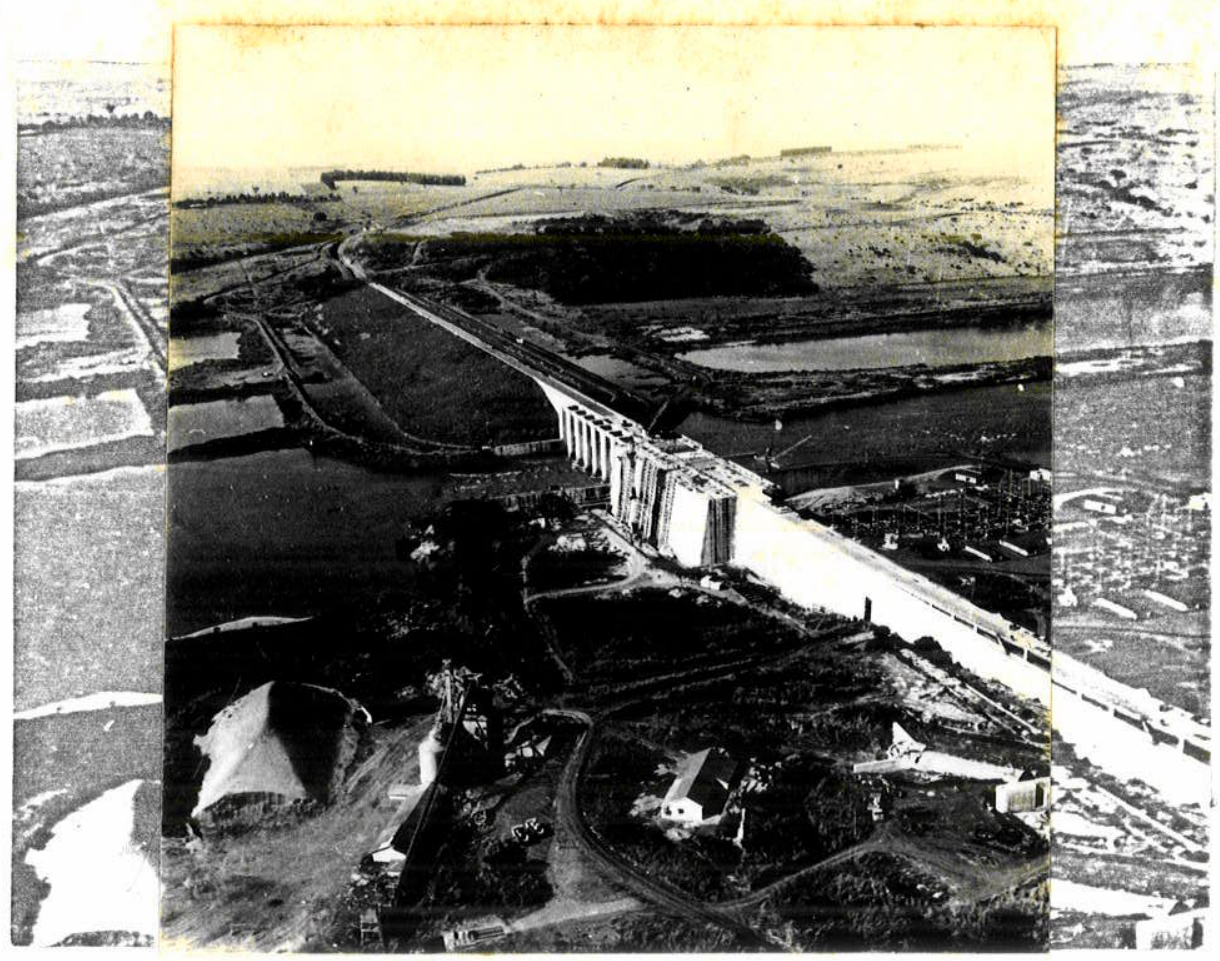

Figura 39 - Barragem de Ibitinga no rio Tietê. Término de constru ção em 1969.

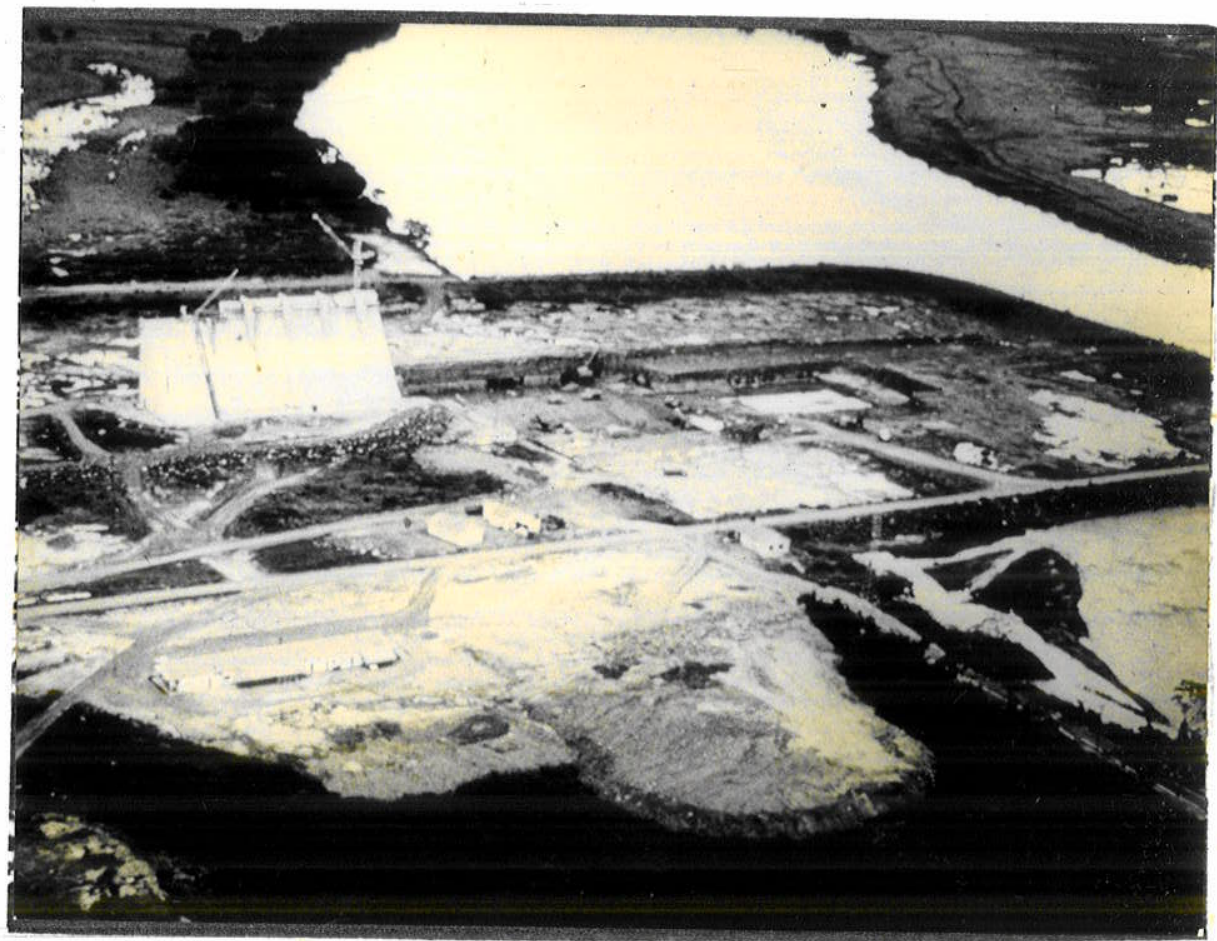

Figura 40 - Escavações na área ensecada de Promissão (1968). 
as escavações profundas, realizadas em particular para as casas de força, interceptando um ou mais derrames basālticos, assemelham-se a posos de escala regional, provocando a queda das cargas piezométricas atē provavelmente, grandes distâncias (várias centenas de metros).

A concretagem (figura 41) introduz novas alterações no quadro hidrogeotécnico, sobretudo pelo fechamento de pontos de saỉda d'â gua das decontinuidades interceptadas. Nesta fase é instalada a drenagem super ficial pela implantação das meias-canas na superfície de concretagem (figura 42) e sobre descontinuidades importantes interceptadas pela escavação.

Tais alterações sugerem a observação dos principais aquíferos envolvidos, através de medidas de cargas piezométricas e de vazão, de maneira a se definir seus comportamentos. Como se vê, a fase de construção da barragem pode ser considerada como um verdadeiro en saio, sugerindo seu aproveitamento nesse sentido, uma vez que os re sultados obtidos podem ser usados não só para uma melhor adaptação dos tratamentos projetados, mas tambēm para uma previsão mais ade quada do comportamento das fundações durante e após o enchimento do reservatório.

E, em geral, durante ou após a concretagem dos blocos da bar ragem que as injeções (em todas as barragens analisadas, injeções de calda de cimento) para construção das cortinas de vedação, são realizadas. Normalmente, depois das cortinas realizadas é iniciada a perfuração do maciço para implantação da drenagem profunda.

A própria execução destes tratamentos de fundação, se devidą mente acompanhados, permite, através da análise de seus resultados um conhecimento complementar (embora a isso não se destinem) do ma ciço rochoso. Com efeito, as absorções de calda, ao longo do mací ço, identificam os condicionantes principais, destacando as estrutu ras basálticas pelo critério da injetabilidade. A determinação dos 


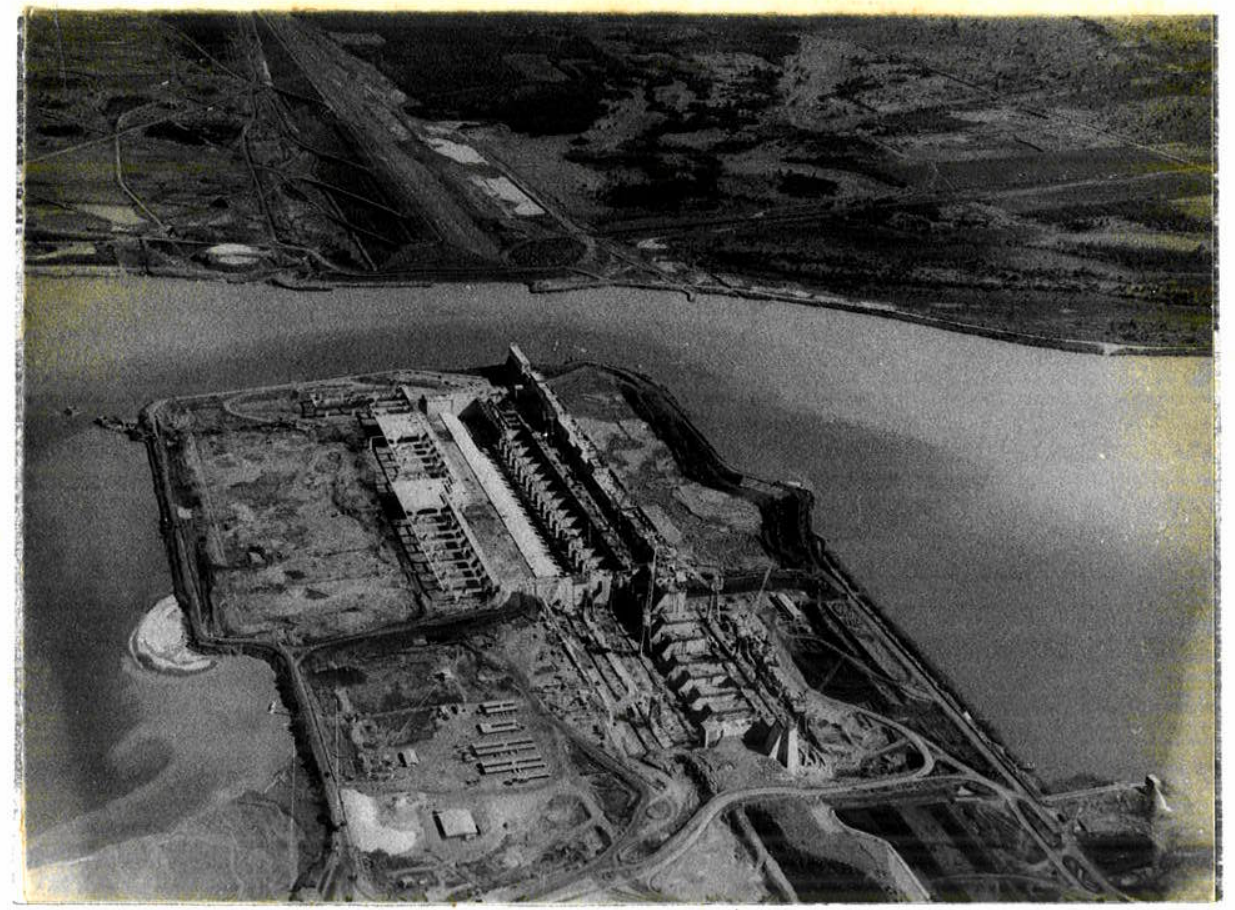

Figura 41 - Fase de concretagem dos blocos na barragem de Ilha Sol teira (1974).

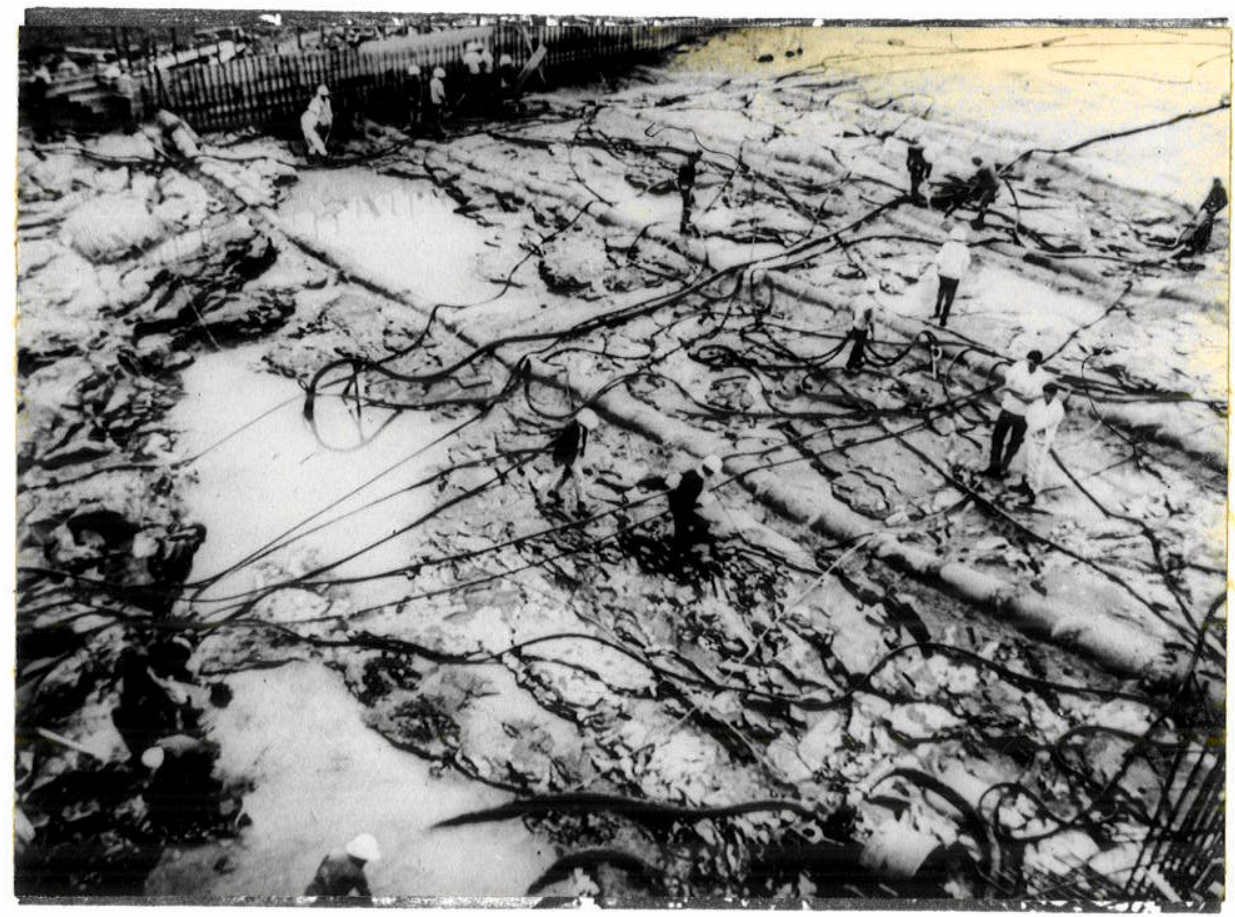

Figura 42 - Instalação de meias-canas previamente à concretagem dos blocos na barragem de Ilha solteira (1973). 
níveis d'água nos furos de drenagem, ä medida em que são executados e após perfuração final, permite, por outro lado, complementar o co nhecimento das caracterỉsticas hidrogeotécnicas das fundações com dados numerosos de cargas piezométricas.

III.3. - Enchimento do reservatörio e operação

A fase de enchimento do reservatório é preparada anteriormen te por um projeto que define não só a velocidade e as etapas com que se deve prosseguir até o nível mäximo, mas também pela pre visão e instalação correspondente de instrumentos que permitam a auscultação da barragem e suas fundações. Este plano de instrumen tação é assim imprescindível para se verificar se o comportamento do sistema obra $x$ fundações é compatível com o projeto realizado e as hipöteses assumidas e, portanto, se o sistema permanece dentro dos limites de segurança definidos.

A importância desta preocupação e a correspondente ausculta ção do sistema transcende a própria obra. Com efeito, o enchimento do reservatório, sendo considerado um ensaio em verdadeira grande za tem possibilitado, através de uma análise adequada do comporta mento do sistema, um continuo aperfeiçoamento dos projetos.

Nas barragens analisadas a instrumentação refere-se basicamen te aos piezômetros, cujas medidas de carga piezométrica associadas às de vazão obtidas nos drenos, permitem caracterizar o comporta mento hidrogeotécnico das fundações. Em todas estas barragens os piezômetros foram instalados preferencialmente no contato do con creto com a rocha. Somente em Ibitinga (junta-falha), Promissão(vā rios contatos), Capivara (contato e zona extremamente fraturada) e Agua Vermelha (contato) foram instalados piezômetros em desconti nuidades profundas, dentre as barragens analisadas. 
IV.

- OS BASALTOS DA FORMAÇÃO SERRA GERAL COMO FUNDAÇÃO DE BARRA

\section{GENS DO TIPO GRAVIDADE}

Embora restrita a 7 locais de barragens consideradas, a análise da experiência adquirida pode ser levada até a sintese do comporta mento hidrogeotécnico dos basaltos, na medida em que seus resulta dos sejam consistentes frente ao referencial cientifico, anterior mente estabelecido.

A experiência adquirida envolve os comportamentos hidrogeotéc nicos observados, não só durante o enchimento do reservatório e o peração, mas também durante a construção e as etapas iniciais de estudos para o projeto.

A observação e caracterização dos comportamentos dependem não só dos fatos e fenômenos observados, mas também dos instrumentos e metodolo gias de observação o que exige um balanço critico das tëcnicas até hoje empregadas.

IV.I. - Etapa de estudos para o projeto

Na fase de investigação dos locais para implantação de barra gens foram realizados mapeamentos de superfície e investigações de subsuperficie. As estruturas de concreto, localizando-se nos lei tos dos rios, tiveram sua investigação prejudicada pela presença de uma lâmina d'água permanente. Estas investigações foram dirigidas i nicialmente no sentido de se compartimentar os maciços, ou seja, delimitar os derrames existentes nos locais. Os mapeamentos de su perfîcie tiveram sua importância relevada pelaidentificação de estrutü ras basálticas de importância hidrogeotēcnica, que eventualmente a floravim nos leitos dos rios. Pode-se citar,como exemplos, os aflora mentos do contato 275 em Ilha Solteira, do 348 em Promissão e das estruturas circulares de Agua Vermelha. 
As investigações de subsuperfície foram basicamente realizadas através de sondagens rotativas, numa área definida ao longo do eixo da barragem. Após a ex periência de Ilha. Solteira em que se ressaltou o quanto era indispensāvel uma re cuperação satisfatōria de testemunhos (FERREIRA,1970) ou,em falta, a interpretação geotécnica aceitável das causas dessa falta, as sondagens tem permitido iden tificar, com relativa facilidade, as estruturas basälticas mais importantes de cada local. O estado atual do equipamento de sondagens atualmente empregado pode ser examinado no trabalho de MONTICELI, GERAIDO e SOARES (1978). A identificação de faixas fraturadas de grande extensão depende da persistência com que ocorrem en determinadas cotas, permitindo a correlação entre as sondagens.

Os dados assim obtidos têm permitido compartimentar os maciços, destacando os derrames que os constituem e suas principais estruturas. Em Agua Vermelha, 으 bra mais recente, novas tēcnicas de investigação foram introduzidas: as sonda gens com amostragem integral anteriormente relatadas (veja item VII. 1 da la Par te) e poço de grande diâmetro,além de uma galeria seguindo o contato 305 e per mitindo investigar uma das estruturas circulares (MOURA FILHO e SORREGOIE, 1975). Excetuando-se estas ültimas técnicas, as sondagens convencionais e os mapeamen tos de superfỉcie não tem permitido senão observações qualitativas sobre parâme tros tais como abertura de fraturas e sua continuidade e rugosidade.

Em geral, os dados hidrogeotécnicos das fundações das barra gens se resumem à definição da permeabilidade dos maciços, segundo os resultados dos ensaios de perda d'āgua sob pressão, realizados sistematicamente nas sondagens rotativas de investigação. No entan to, alëm de tais ensaios estarem sujeitos a limitações importantes

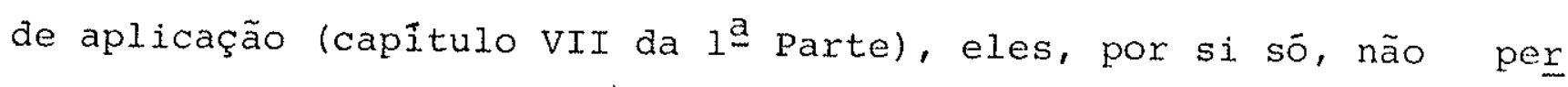
mitem a caracterização hidrodinâmica dos maciços. As limitações mais citadas são: faixa mensurável de permeabilidade normalmente en tre $10^{-3}$ e $10^{-5} \mathrm{~cm} / \mathrm{s}$ (acima: perda total da vazão da bomba; abaixo: vazão nula); perdas de carga e outros problemas hidräulicos que mascaram a carga efetivamente aplicada; medidas provavelmen te feitas em regime transitörio (SILVA, ARAUJO e MONTICELI, 1978). 
Tendo em vista estas limitações, a aplicação de outras técni cas sempre possibilitou um ganho importante no grau de conhecimento do comportamento hidrogeotécnico do maciço, não só por permitir uma aferição dos resultados obtidos nos ensaios sob pressão, mas sobre tudo por possibilitar uma complementação do quadro hidrogeotécnico. Estas outras técnicas são, por exemplo, os ensaios com traçadores e os ensaios de bombeamento, cuja aplicação contudo é pouco frequente.

Exemplos de aplicação de ensaios com traçadores foram anterior mente citados no item II.6.2 (SANCHES, GUIDICINI e SILVA, 1975 e IPT - Relatório 7.164 - 1973). A estes pode-se acrescentar os realizados por OLIVEIRA, SILVA E LIMA (1966) em Barra Bonita, cujos resultados, no entanto, não corresponderam às expectativas iniciais.

Ensaios de bombeamento, alēm dos executados por NUSKE (1970) e apresentados no item II.5.3, ressaltam-se aqueles executados em Água Vermelha com bombas elétricas submersas em furos de sondagens rotativas. Seus principais resultados foram os seguintes: os ensaios permitem deter minar valores de permeabilidade além dos limites de aplicação dos ensaios de perda d'água sob pressão; os ensaios envolvem porções maiores do maciço podendo identificar seus parâmetros hidrodinâmi cos, zonas de recarga e outros comportamentos que permitem caracte rizar melhor os aquiferos testados (SILVA, ARAUJO e MONTICELLT, 1978): A figura 43 apresenta esquematicamente a configuração das linhas pie zométricas antes e durante o ensaio de bombeamento em Āgua Verme Iha permitindo identificar a estrutura circular como importante zo na de recarga.

Quando, no entanto, o maciço a ser ensaiado encontra-se em zo nas não saturadas, a determinação das caracteristicas hidrāulicas de suas' estruturas não pode ser efetuada senão com a injeção d'āgua cujos volumes podem ser muitas vezes superiores aos exigidos pelos 
$\operatorname{cotas}(\mathrm{m})$

COTAS $(m)$

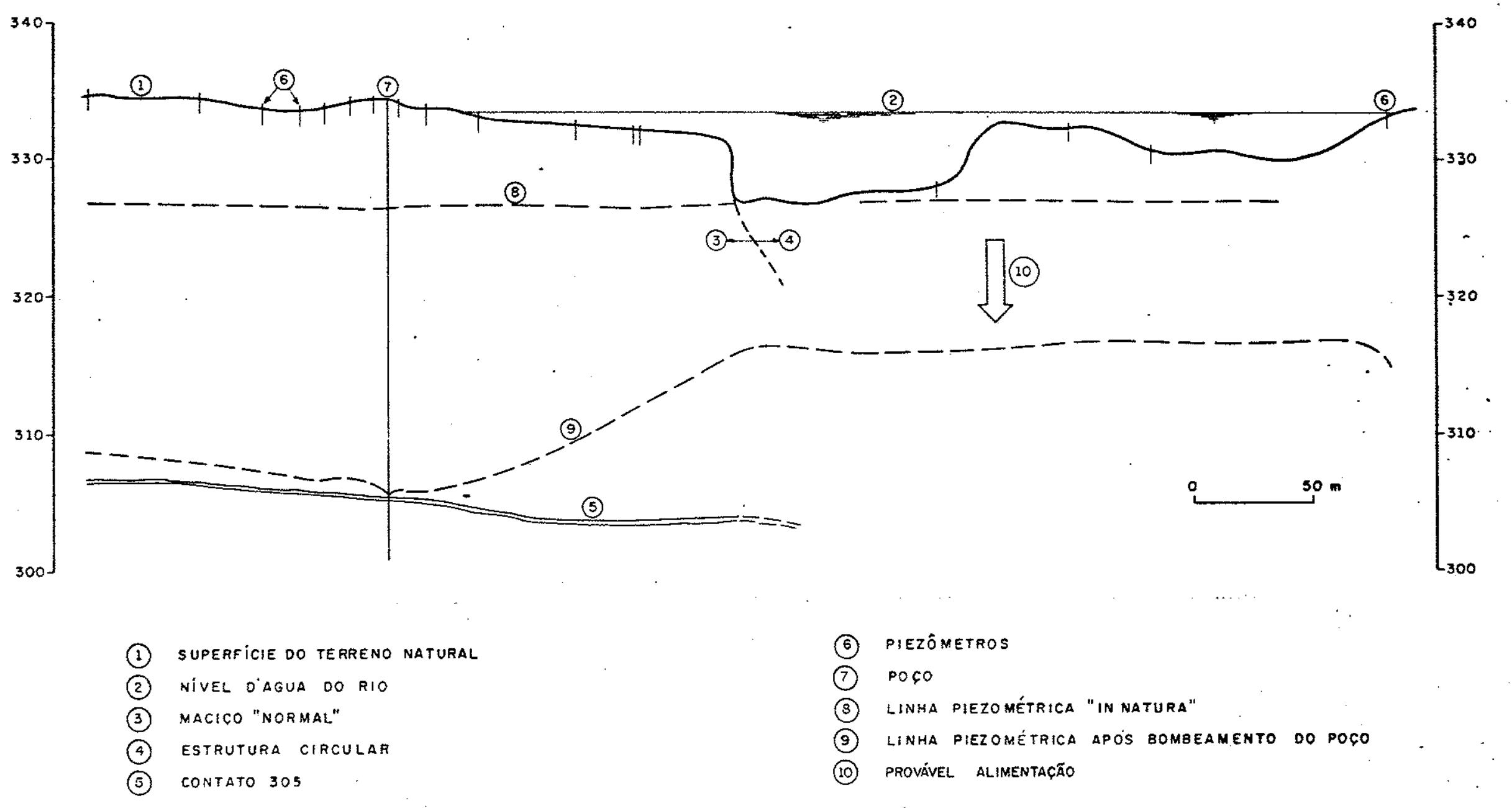

Figura 43 - Linhas piezométricas do contato 305 em seção paralela do eixo da barragem de Água Verme tha (Modificado de SHVA, ARAUJO e MONTICELI, 1978). 
ensaios de perda d'água sob pressão. Pode-se citar, como exemplo ünico, os ensaios realizados na ombreira esquerda de Agua Vermelha, os quais foram complementados por ensaios de traçadores com o uso de sal de cloreto de sódio e medidas de condutividade (SILVA, ARAOJO e MONTICELI, 1978).

A realização destas investigações tem permitido determinax as principais caracteristicas hidrogeotécnicas dos maciços. Estabeleci do este quadro estätico do maciço, o passo seguinte seria dinamizăTo examinando seu comportamento através de estudo piezométrico.

Contudo, nesta etapa de investigação, apenas Água Vermelha pode ser citada como exemplo de aplicação de tal estudo (IPT - Relatório 12.513 - 1979) no qual evidenciou-se o condicionante, de ordem geomorfológi.ca, constituído pela cachoeira, nas cargas piezomëtricas medidas (veja item II.5).

\section{2. - Etapa de Construção}

Conforme observado anteriormente (item III), esta etapa, que se inicia pela construção de ensecadeiras e escavação do maciço, proporciona uma série de condições propícias ao melhor conhecimento do comportamento hidrogeotécnico.

Primeiramente, as escavações proporcionam condições similares a um ensaio de rebaixamento em grande escala e, durante a concreta. gem, condições de realização de ensaios hidrogeotécnicos globais, a segurx citados.

Nas escavações em maciços basálticos, no leito dos rios, temse observado que as infiltxações ocorrem predominantemente atravēs de suas descontinuidades principais (contatos e juntas horizontais de grande extensão). O comportamento típico observado é a saĩda a bundante de āgua das descontinuidades tão logo sejam desconfinadas. Em alguns casos ocorre diminuição do fluxo d'áqua, sendo es ta diminuição reflexo das condições de ocorrência das descontinuida des. Ass vezes, esta diminuição de fluxo é muito grande, chegando mes mo a sua paralização total. A vazão resiaual ë, nestes casos muito 
menor do que a esperada, se são levadas em conta apenas as elevadas permeabilidades e as extensões de tais descontinuidades. Contudo, as observações têm-se mantido num nỉvel qualitativo (OLIVEIRA, SILVA e GUIDICINI, 1976) sendo muito raros os casos de simples medidas de vazão colhidas nas escavações e de medidas do rebaixamento das car gas piezométricas provocado por elas. Em geral, a análise do compor tamento é somente iniciada com o enchimento do reservatório, atra vēs da instrumentação instalada para esse fim. Nas fases anteriores, das barragens analisadas neste trabalho, puderam ser colhidas ape nas algumas informações qualitativas ou semi-quantitativas que, ape sar de extremamente importantes, não foram suficientemente explora das para fins de projeto. A título de exemplo:

a. - Ibitinga: medidas piezométricas realizadas na junta-falha, du rante as primeiras fases de construção, indicaram certa correlação com as oscilações do nível do rio. Durante o enchimento do reserva tório (veja item IV.3), verificou-se alimentação importante da junta na margem direita (GUIDICINI, OLIVEIRA e MATUOKA, 1970);

b. - Ilha Solteira: a observação direta das infiltrações nas escava ções revelou que a brecha se comportava como praticamente impermeá vel, enquanto que os ensaios de perda d'água acusavam 40\% dos seus resultados superiores a $10^{-2} \mathrm{~cm} / \mathrm{s}$ (SILVA, 1976);

c. - Promissão: as medidas de vazão num ūnico poço de $27 \mathrm{~m}^{2}$ de se ção assinalaram $1.0001 /$ min para o contato 336, durante a fase cons trutiva. A vazão máxima atingida por este contato, após o enchimen to do reservatōrio, com todo o sistema de drenagem em operação, foi de apenas 400 l/min a mais (OLIVEIRA e CORREIA FILHO, 1976).

Durante a etapa de concretagem contudo, destacam-se os ensaios hidrogeotécnicos globais, executados em Promissão (OLIVEIRA e CORREA FILHO, 1976) e assim denominados por envolverem praticamente todo 
o maciço de fundação e suas principais estruturas. A metodologia de sua execução é resumidamente apresentada a seguir.

Com a escavação realizada para a implantação das estruturas de concreto da barragem de Promissão, alguns aquỉeros confinados (con tatos entre derrames) foram interceptados.Com a concretagem dos blocos as saídas d'āgua foram organizadas em pontos localizados. Assim, na etapa da concretagem dispôs-se de meios de controle desses pontos, podendo-se interromper totalmente a drenagem dos aquíferos e observar as respostas piezométricas em piezômetros convenientemente instalados na área. Diversas combinações de drenagem foram então programadas e realizadas, abrindo-se sucessivamente os pontos de saỉda d'água. A análise dos resultados obtidos permitiu uma ampla caracterização do comportamento hidrogeotécnico de tais contatos, condicionando al terações do projeto de tratamento das fundações.

IV.2.1. - Tratamento das fundações

Examinado pela ótica do comportamento hidrogeotēcnico dos mạ ciços basálticos, os tratamentos das fundações realizadas nas barra gens apresentam dados de extremo interesse. Estes dados referem-se à execução de tais tratamentos, seja aqueles relativos à anālise das absorções de cimento para construção da cortina, seja os obtidos pe la análise dos nỉveis d'água nos drenos sucessivamente abertos.

IV.2.1.1. - Injeções

No trabalho "Injegões em basalto", realizado pelo Instituto de Pesquisas Tecnológicas para a Companhia Energética do Estado de São Paulo procedeu-se a um estudo de sỉntese do assunto cujos resul tados principais, abaixo resumidos, foram posteriormente divulgados por AZEVEDO, OLIVEIRA E SOARES (1978).

Para sua realização foi necessārio compartimentar os maciços segundo suas litologias e estruturas, de comportamentos distintos quanto às injeções. Desta maneira 
comportamentos semelhantes ou diferentes, foram respectivamente, uni ficadas ou individualizadas. A avaliação das litologias que ocorrem em fundações basālticas levou à caracterização de 5 unidades princi pais: contatos RC (rocha x concreto); basaltos compactos ou vesicul lares, sem ou com fraturamento sem extensão lateral significativa; brechas basālticas, siltitos, arenitos e lavas aglomeráticas; fai xas fraturadas com extensão lateral significativa; contatos entre derrames e junta-falha de Ibitinga.

Da mesma forma, porções do maciço de fundação onde foram apli cadas as mesmas técnicas de injeção foram compartimentadas segundo - que șe definiu como procedimento técnico. A definição. desses procedimentos foi baseada nas especificações das projetistase os pa râmetros adotados para caracterizā-los foram: número de linhas de injeção, espaçamento entre furos, pressões aplicadas, tipos de cal da e critérios de recusa de carra (limites de absorção de cada calda e tempo de espera).

Os dados das injeções foram assim tratados tendo como referen ciais básicos de um lado os compartimentos geológicos e de outro os procedimentos técnicos.

Os principais resultados da sintese realizada e de interesse ao conhecimento dos comportamentos hidrogeotécnicos estão abaixo relacionados:

a. - A análise da queda das absorções de cimento com as etapas de injeção, em todos os tratamentos efetuados, ressalta que a major eficiência ${ }^{(*)}$ è antes produto do tipo de estrutura geolögica tratada do que

(*) o conceito de eficiência das injeções aqui usado é relativo à realização das injeções e definido basicamente pela análise das absorções e de ensaios de perda d'ägua sob pressão. A eficiêencia da cortina de vedação, por outro lado diz respeito à verificação de seus objetivos de controle das percolações o que só pode ser adequadamente feito durante e após o enchimento do reservató rio. Assim, deve-se observar que injeçōes eficientes não promoven neces
sariamente uma eficiência da cortina. 
do procedimento técnico empregado, ou seja, è nas estruturas que apresentam um maior grau de injetabilidade (faixas fraturadas, con tatos entre derrames, junta-falha) que se verifica maior eficiência das injeções, independentemente da tëcnica utilizada.

b. - Os valores residuais de absorção nas estruturas mais injetá veis permaneceram mais elevados que os das camadas basálticas, le vando a crer que a permeabilidade daquelas estruturas nunca 'será in ferior à do maciço que as contém. A análise dos ensaios de perda a'āgua executados duxante as injeções reforça estas conclusões.

c. - Absorções médias em quilos de cimento por tipo de estrutura (*):

- contatos entre derrames e junta falha de Ibitinga 130 a $450 \mathrm{~kg} /$ furo

- basaltos compacto ou vesicular, brechas e materiais intertrapea nos: 4 a $50 \mathrm{~kg} / \mathrm{m}$

- faixas fraturadas com extensão lateral significativa: 15 a $40 \mathrm{~kg} / \mathrm{m}$. a. - o contato RC apresenta absorções preferencialmente condiciona das por feições geolögicas, quando os efeitos da escavação são pe quenos ou minimizados pelo uso de fogo cuidadoso. Absorções mé - dias de $10 \mathrm{~kg} /$ furo ou $30 \mathrm{~kg} / \mathrm{m}$.

Outros resultados, relativos aos procedimentos técnicos utili zados, merecem ser apresentados, objetivando documentar a experiên cia adquirida:

a. - A análise do comportamento de cada estrutura ou litologia injeta da sugere que os procẹjimentos técnicos mais eficazes são os que fa zem uso de um maior nümero de linhas, pressões mais elevadas e de limites de absorções màis elevadas. O uso de argamassa resultou, na

(*) Estas absorções foram definidas por $\mathrm{kg} /$ furo quando se tratava da injeção de uma descontinuidade específica. No caso de litologias ou faixas fraturadas com espessura significativa, os valores foram definidos por $\mathrm{kg} / \mathrm{m}$. Como os trechos de injeção são em geral de $3 \mathrm{~m}$ pode-se correlacionar tais valores supondo $3 \mathrm{~kg} /$ furo $=1 \mathrm{~kg} / \mathrm{m}$. 
maioria dos casos, em baixa eficiência.

b. - o número de linhas de injeção mais frequentemente utilizado foi três. Cortinas executadas com uma ünica linha parecem não produ zix a eficiência desejada como verificado em Promissão, onde os en saios de perda d'água mostraram a necessidade da duplicação da cor tina. O espaçamento entre furos majs frequentes foi de $3,0 \mathrm{~m}$. Espa çamentos superiores a este valor não surtiram os efeitos desejados como revelaram ensaios prévios de injeção realizados em Barra Boni ta e Ibitinga. O método de perfuração mais utilizado foi o roto-per cursivo no diâmetro de 2 1/2".

c. - As caldas utilizadas nas diversas barragens sofreram uma evolu ção importante propiciada pela sêrie de ensaios realizados nos laboratórios de Ilha soltejxa e do TPT (TATAMIYA e outros, 1972). Antes destes ensaios, exa prätica corrente o uso de caldas ralas, com relação A/C (Agua/Cimento) entre $1,0 / 1,0$ e 8,0/1,0. Apōs aquela série de ensaios introduziu-se o uso de caldas com fator de sedimenta çào bastante reduzido, de relações $A / C$ entre $0,5 / 1,0$ e 0,7/1,0. Tes tes de laboratório mostraram as seguintes vantagens. na utilização de caldas de pozolana: maior resistência à dissoulução, menor permeabilidade além de maior economia no uso de cimento (LEONE e RUIZ, 1970).

a. - As pressões de injeção constituem, das técnicas utilizadas, um dos aspectos menos estudados. Os acrëscimos de pressão,por metro de profundidade do obturador, utilizados com maior freqtuencia, foram de 0,12 
a $0,25 \mathrm{~kg} / \mathrm{cm}^{2}$, próximos à regra empírica americana $\left(1 \mathrm{lb} / \mathrm{pol}^{2}\right.$. pé) .0 uso de pressões mais elevadas aumenta o raio de ação da calda, aumentando a interação entre as etapas de injeção, possibilitando portanto um aumento de eficiência.Não foram verificadas perturbações dos maciços nos casos de uso de pressões mais elevadas.

Finalmente, cumpre assinalar que esse estudo envolveu cerca de 6300 furos, aproximadamente 100 quilometros de furos injetados cujos dados médios foram os seguintes:

- $400 \mathrm{~kg}$ por metro de cortina realizada

- $350 \mathrm{~kg}$ por furo ou $20 \mathrm{~kg}$ por metro linear de furo injetado.

IV.2.1.2. - Drenagem

A experiência colhida nos trabalhos de drenagem reflete mais de perto o comportamento dos maciços, pois constitui, ao mesmo tem po, um elemento de tratamento e de auscultação, ao longo do tempo.

A drenagem através de um furo tem um raio de ação, ao longo de um plano de descontinuidade importante, de várias dezenas de me tros de extensão chegando, muitas vezes, a atingix centenas de me tros, dependendo do estado de drenagem e confinamento a que está submetida a des continuidade. Essa extrema sensibilidade das pressões piezomētricas à implantação dos arenos é devida ao carāter confinado dos aquífe ros que as descontinuidades de alta permeabilidade constituem. Dados os espaçamentos mais usuais dos drenos (3 a $6 \mathrm{~m}$ ), a intercomunica. ção e interdependência dos drenos são a regra geral no sistema de drenagem que atinge as referidas fendas. São os primeiros furos que provocam as maiores quedas de pressão. O efeito dos seguintes tor na-se cada vez menor, sugerindo a existência de um limite de dreria bilidade.

Individualmente, as vazões dos drenos podem variar em gama bas tante vasta, desde secos até mesmo $1000 \mathrm{l} / \mathrm{min}$. Drenos conti guos e intercomunicados apresentam diferenças de vazão da ordem de 
algumas centenas de vezes, refletindo significativas variações pontuais na permeabilidade das fendas, que ora estão francamente abertas, ora fechadas por justaposição das paredes da fenda ou, ainda, colmatạ das por material de alteração ou precipitação química. A percolação d'água concentrada em canalículos que se distribuem irregularmente nos planos das descontinuidades conforme proposto por SABARLY, PAU TRE e LONDE (1970) pode traduzir tal comportamento.

E comum o sistema de drenagem interceptar duas ou mais descon - tinujdades provocando uma intercomunicação dos aquiferos sendo que, localmente, uma descontinuidade passa a drenar outras.

IV.2.3. - Ensaio hidrogeotēcnico global

Embora tal tipo de ensaio tenha somente sido executado em Pro missão, trata-se de uma experiência que pođe ser importante na ava liação do comportamento hidrogeotëcnico de uma fundação basāltica, durante a etapa de construção da barragem.

Foram dois os ensaios hidrogeotēcnicos executados, segundo uma metodologia simples, já apresentada na introdução ao item IV.2. De ve-se contudo observar que a execução destes ensaios requer não só um pleno conhecimento das feições geolögicas locais mas sobretudo do relacionamento destas feições com as estruturas de concreto que estão em processo de construção. Exige portanto uma familiaridade permanente com o avanço da obra.

O primeiro ensaio foi realizado com o objetivo de se verificar a possibilidade de afluxo d'āgua excessivo ao sistema especial de drenagem da eclusa com o.enchimento do reservatörio. Este sistema foi exigido pelas condições especiais de estabilidade dos blocos da eclusa, geradas pela presença do contato 336 cujo mergulho local era desfavorável a essa estabilidade (figura 44). Os resultados do primeiro ensaio confirmaram, de início,as condições hidrogeotēc 


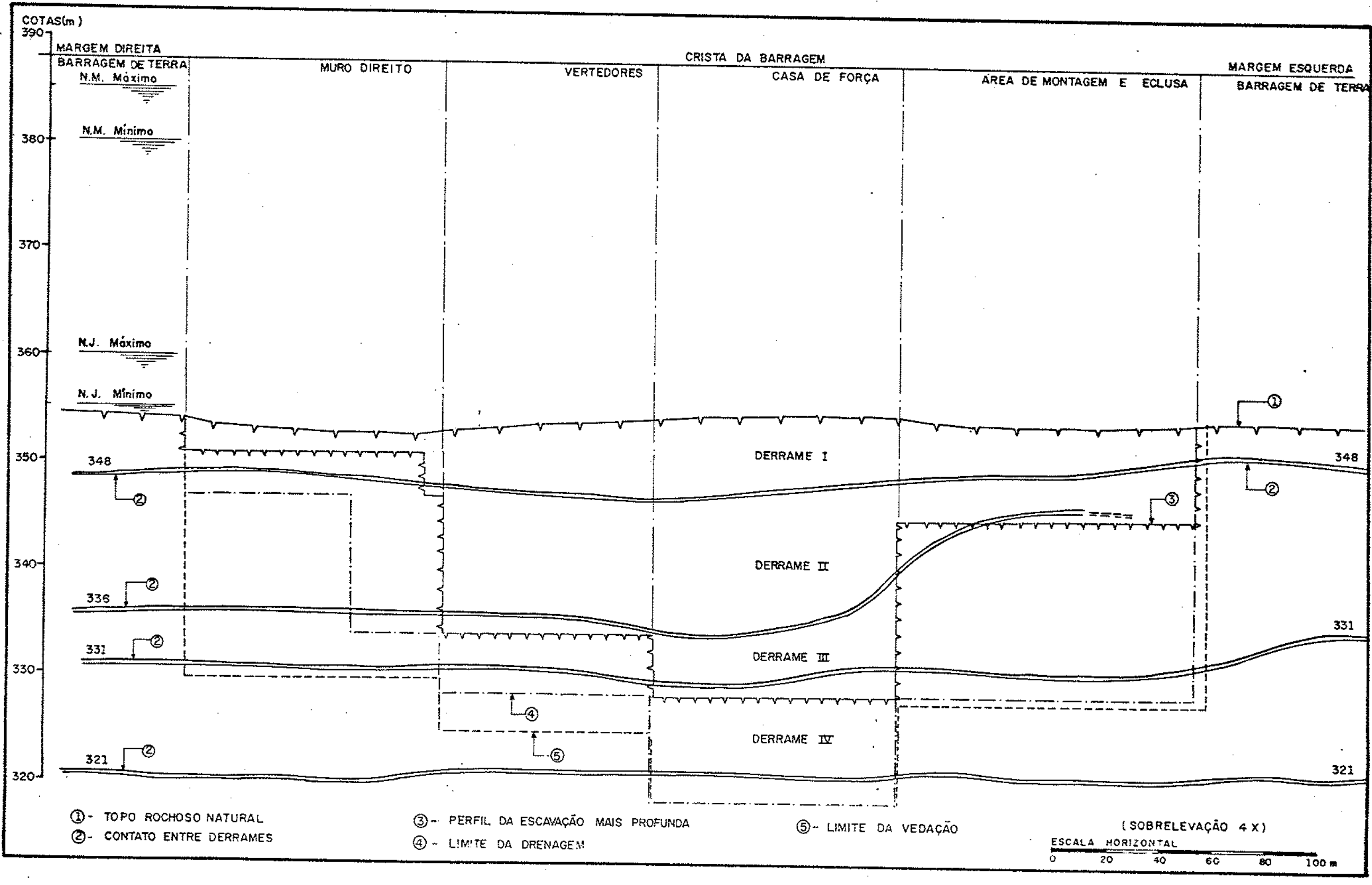

Figura 44 - Seção longitudinal esquemātica das fundações das estruturas de concreto da barragem Promissão (OLIVEIRA e CORREA FILHO, 1976). 
nicas do maciço, apontadas na etapa de estudos para o projeto. Ou seja, os contatos entre os derrames correspondem a fendas sub-hor $\underline{i}$ zontais que constituem aquiferos de grande extensão e alta permeabili dade. Os maciços entre as fendas são praticamente impermeãveis, o que confere aos aquiferos um certo confinamento e portanto comporta mentos hidrogeotēcnicos independentes. Em segundo lugar, os resulta dos mostraram que as modificações introduzidas pela obra provocaram a alteração do fluxo d'água no contato 336 , que passou a ser desvia do pela margem direita, atingindo o sistema de drenagem da eclusa por jusante. Ensaios com traçadores (corantes) realizados nessa oca sião comprovaram esta hipōtese.

Considerando esta situação e temendo que o enchimento do re servatório pudesse provocax um aumento substancial da vazão no sis tema, a Projetista optou pela execução de uma cortina de vedação a jusante, envolvendo a eclusa.

o segundo ensaio foi realizado com o objetivo de se verificar a eficiência da cortina de jusante no controle da percolação no con tato 336. A Eigura 45 aprésenta o comportamento de alguns pontos de - medida de vazões e cargas piezométricas, considerados representati vos. Os principais resultados deste ensaio revelaram um certa efi ciência da cortina: constatou-se uma diminuição das vazões de cerca de $30 \%$ no sistema de drenagem, e um rebaixamento de mais 1,0 a $2,0 \mathrm{~m}$ nas cargas piezometricas no interior da eclusa. Fora da eclusa, ao conträrio, os efeitos do sistema resultaram mais atenuados.

De maneira geral, os dois ensaios mostraram que as cargas piezométricas e as vazões não viriam a sofrer incremento ponderävel com o enchimento do reservatório. Para se assegurar desta conclusão final séria necessārio verificar a possivel ocorrência de aflora mentos dos contatos na ärea do futuro reservatório. Conhecia-se a existência de afloramentos do contato 348 na margem esquerda e sus 


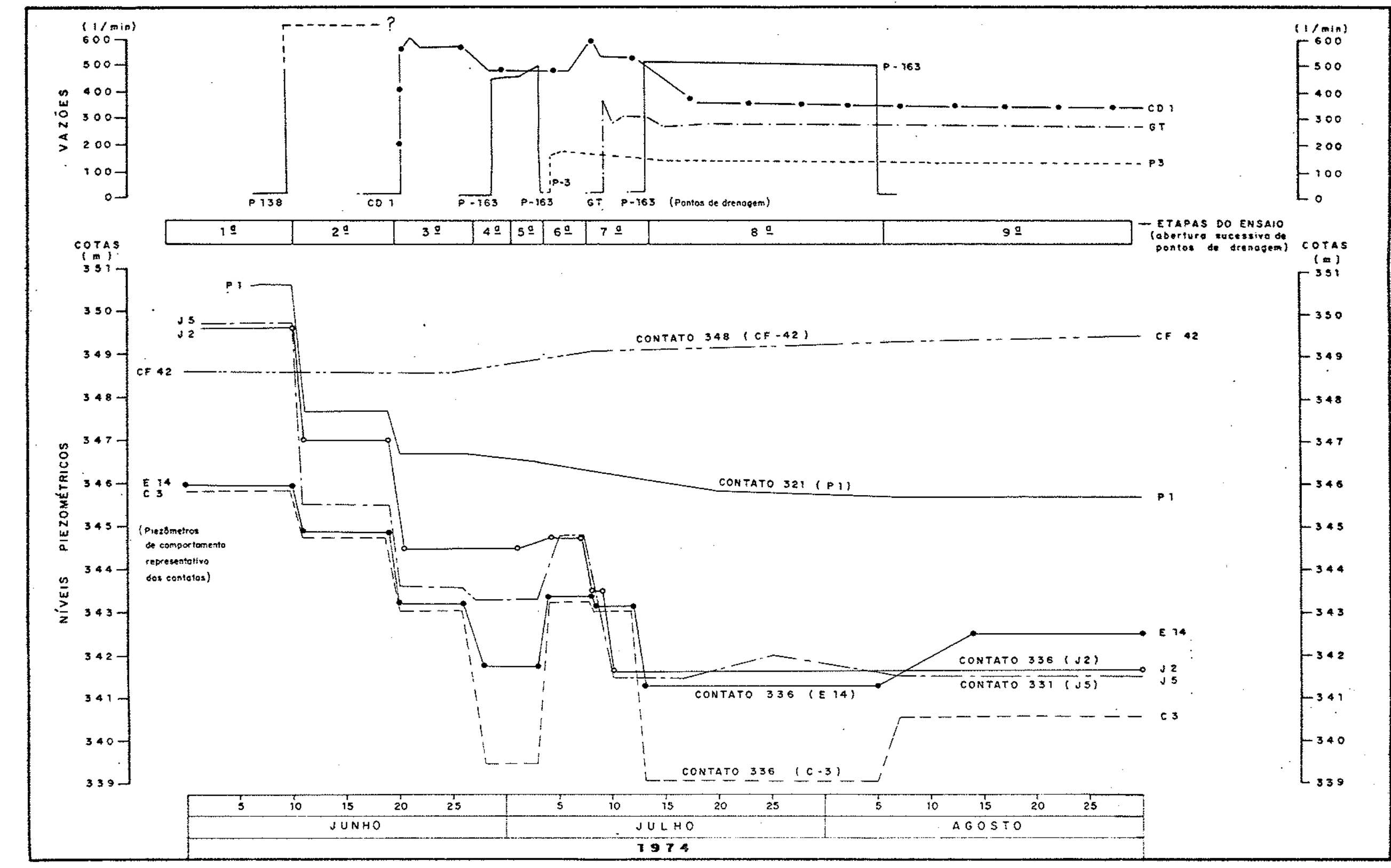

Figura 45 - Resultados do 29 ensaio hidrogeotëcnico global na barragem de Promissão (OLIVEIRA CORREA EILHO, 1976). 
peitava-se que o mesmo aflorasse no leito do rio. A possibilidadede afloramento do contato 336 , no mínimo cerca de $5,0 \mathrm{~m}$ abaixo do 348 podia ser considerada remota. Por outro lado, uma possivel infiltra Ção Eranca e direta do reservatório no contato 348 teria uma ação restrita ao muro direito, devendo atingir o contato 336, a princi pal feição geotécnica das fundações, apōs atravessar pelo menos $5,0 \mathrm{~m}$ do maciço praticamente impermeável, ou seja, a custo de uma perda de carga considerável (OLIVEIRA e CORREA FILHO, 1976).

Pode-se portanto considerar que os ensaios hidrogeotēcnicos globais constituem uma técnica de aplicação altamente favorāvel e ao mesmo tempo simples, para caracterizar o comportamento hiarogeotécnico dos basaltos. No caso de promissão possibilitaram resultados ex tremamente valiosos não só para indicação de tratamentos complemen tares e orientação da instrumentação, mas sobretudo para uma anāli se da previsão do comportamento futuro das fundações com o enchimen to do reservatório.

\section{IV.3. - Enchimento do reservatório e operação}

A observação dos drenos (medidas de vazão, anālise da ãgua drenada e medidas de nível d'água em drenos não vertentes) e a medida das subpressões através de piezômetros instalados nas fundações, consti tuem os principais instrumentos de análise do comportamento hidrogeotécnico dos maciços basälticos frente às solicitações impostas pelo enchimento do reservatório e operação da barragem.

A instrumentação usada e a auscultação hidrāulica vem permi tindo esclarecer uma série de aspectos relativos a esse comportamen to.

IV.3.1. - o papel das descontinuidades

As descontinuidades importantes, representadas basicamente pe los contatos e juntas-falhas, por constituirem estruturas de eleva 
da permeabilidade abrigandó aquíferos confinados, exercem um papel essencialmente drenante nos maciços de fundação: Este papel é tanto mais significativo quanto mais sujejtas à arenagem imposta pela re de de drenos profundos da baxragem, e quanto mais isoladas estejam do fundo do reservatório pelos maciços basálticos praticamente im permeãveis.

Este papel pode ser exemplificado na figura 46 que apresenta 0 enchimento do reservatório e um ano de operação da barragem de prọ missão. o enchimento do reservatório praticamente não alterou o qua dro hidrogeotécnico geral. Os contatos apresentam um comportamento independente, excetuando 0336 e o 331 por condições impostas pela própria obra (veja item IV.3.2. a seguir). O fechamento de impor tante dreno (vazão de $10001 / \mathrm{min}$ ) do contato 321 provocou a eleva ção nitida das cargas piezométricas deste contato sem que, contudo, os demais apresentassem alterações significativas em seus respecti vos comportamentos.

Por outro lado, o enchimento do reservatório de Ibitinga pro vocou a elevação das cargas piezométricas da junta-falha na área da margem esquerda. Do lado direjto a situação permaneceu pratica mente inalterada (GUIDICINI, OLIVEIRA e MATUOKA, 1970) como pode ser observado na figura 47. A elevação das cargas desta descontinui dade, acompanhando o enchimento, sugere a existência, naquela ärea, de elementos que promoveriam a alimentação da água do reservatōrio, possivelmente um fraturamento vertical, associado à inflexäo local da junta-falha como pode ser visto na seção geológica pelo eixo da barragem (figura 48). Este local é o ponto onde a junta-falha mais se aproxima do leito dó rio (cerca de $10 \mathrm{~m}$ ). Cabe ainda lembrar que, durante a fase construtiva, verificou-se que havia influência das oscilações do nível d’água do rio nas cargas piezométricas da junta. Ainda na figura 47 observa-se a queda signi ficativa de subpressões apōs a execução de drenagem complementar na 


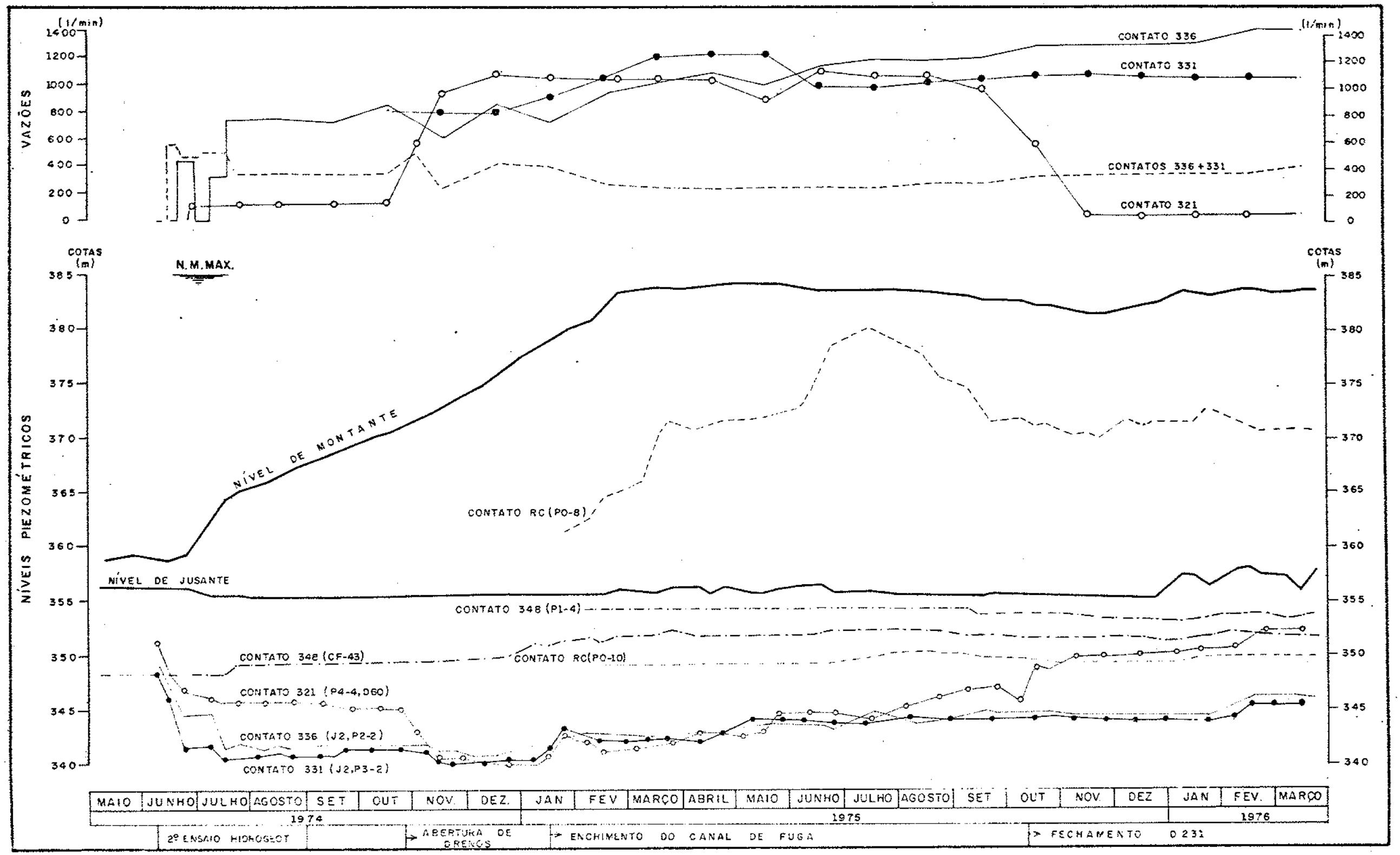

Figura 46 - Acompanhamento hidrogeotécnico do enchimento do reservatório de Promissão (OLIVEIRP e CORREA FILHO, 1976). 


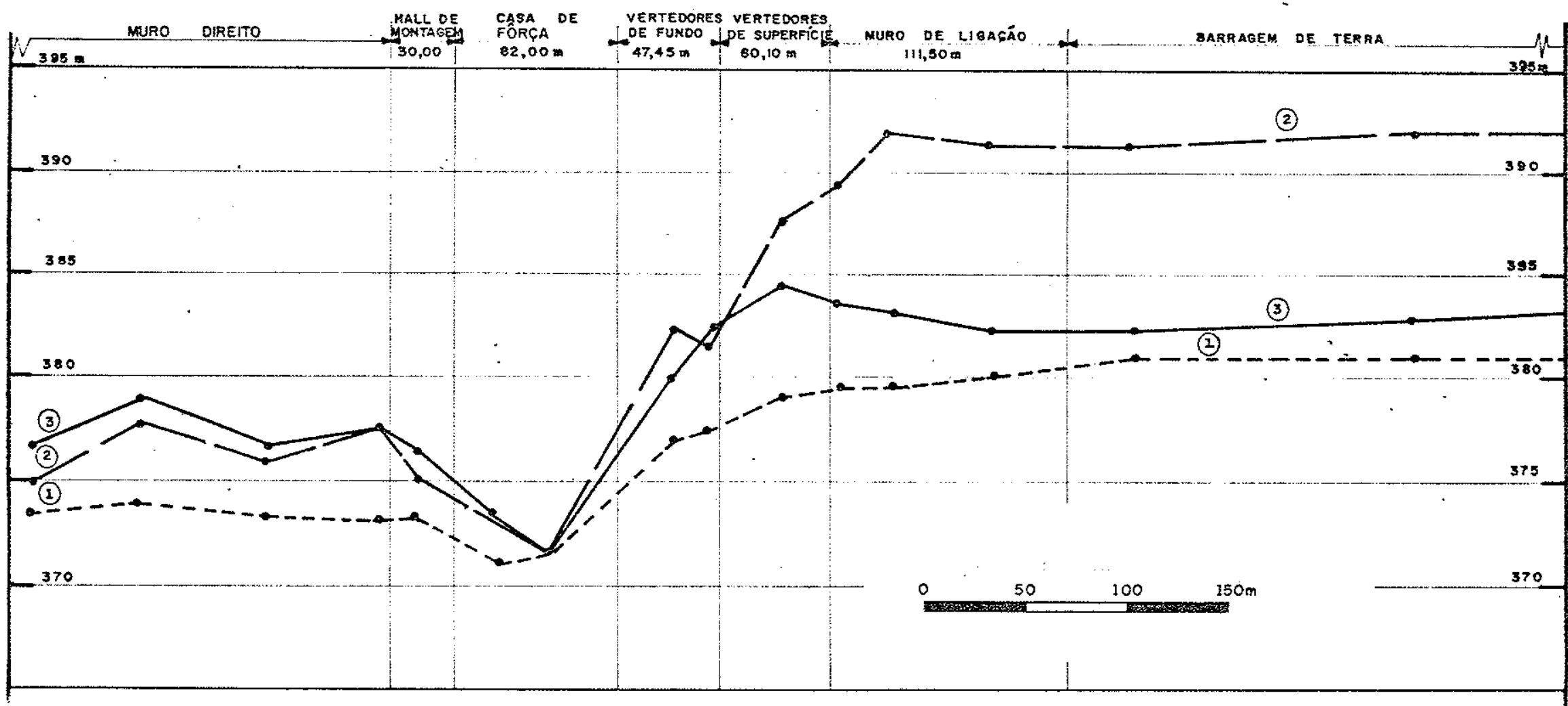

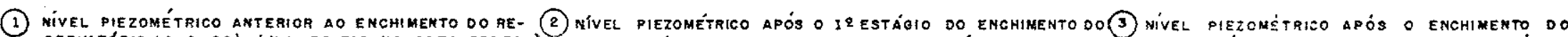
SERVATÓRIO $(1-i+69)-\{$ N.A. DO RIO NA COTA $380.70 \mathrm{~m}\}$ RESERVATORIO-(1-3-89)-(N.A.DO RESERVATÓRIO NA COTA RESERYATÉRIO E ABERTURA DOS POÇOS DE ALIVIO 12-69)-(M.A. DO RESERVATORIO NA COTA $403.70=)$

Figura 47 - Subpressões da junta-falha de Ibitinga em seção pelo eixo da barragem (GUIDICINI, OLIVEI , RA E MATUOKA, 1970). 


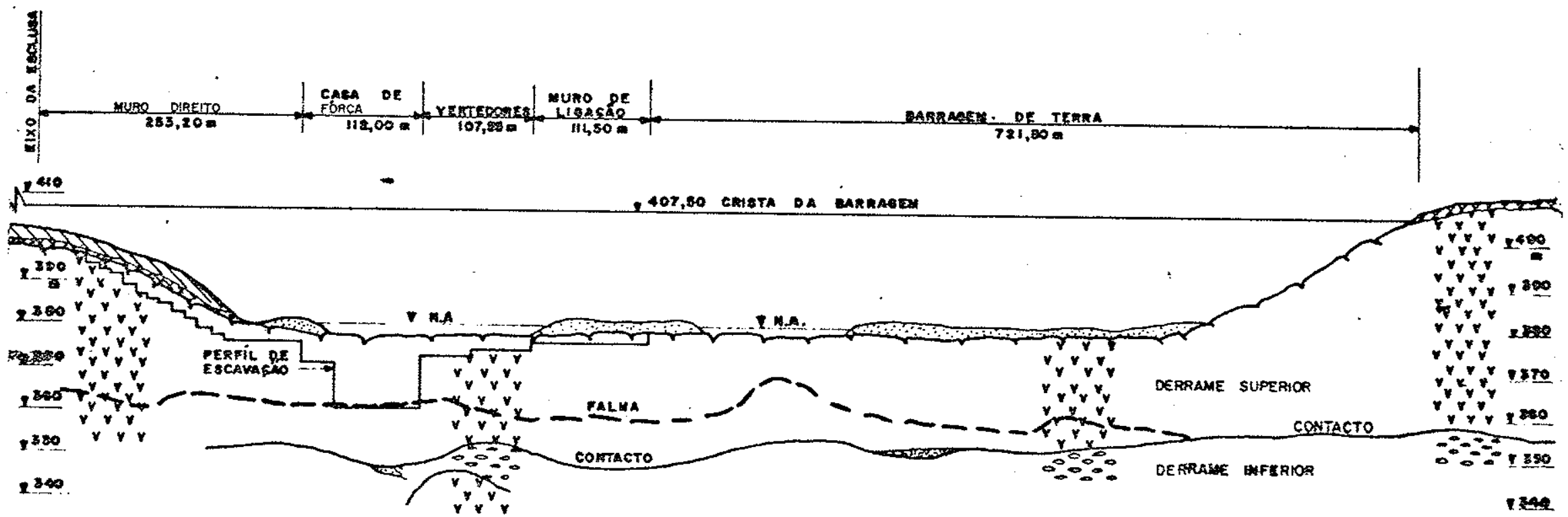

VVV
$V V$ SASALTO COMPACTO


barragem de terra.

Como jä foi apontado, o papel destas descontinuidades depende não somente de suas propriedades hidräulicas intrinsecas e de sua forma de ocorrência, mas das alterações impostas pela execução da pró pria obra que, no quadro hidrogeotëcnico, nada mais são que condições de contor no. Estas condições são examináadas a seguir.

IV.3.2. - Condições impostas pela interligação das descontinuidades através dos arenos profundos

No muro direjto de promissão a situação das cargas piezométrí cas nos contatos entre derrames sugere que o contato 348 é drenado, em profundidade pelos contatos 336 e 331 através dos arenos profun dos que os interceptam. Esta situação explica o fato das subpres sões se manterem abaixo do piso da galeria des ta estrutura e portanto a ausência de vazão na galeria de drenagem, apesar de ter sido constatada a ocorrência de afloramentos no re servatōrio, do contato mais superficial. A drenagem do muro direito seria feita, indiretamente, pela ärea da casa de força onde os con tatos inferiores se encontram intensamente drenados (veja itemIV.3.4 ). A intensa interligação dos contatos 336 e 331 promovida por drenos profundos é a responsável pelo comportamento semelhante dos mesmos como foi observado na figura 46.

Na soleira dos vertedores de Capivara a situação das cargas sugere que o contato 292 exerce uma parcela da drenagem da faixa fraturada da cota 306 (SAMPATO, 1976). Estas condições envolvem não somente as descontinuidades entre si mas podem exercer significativa influência no estabelecimento de subpressões nas bases das barragens (contato RC).

IV.3.3. - Condições impostas pelos efeitos da drenagem superti cial

Em várias barragens procedeu-se à drenagem na superfície das 
fundações imnlantando-se mieias-canas na superficie de concretagem (figura 42). Os efeitos desta drenagem, associados aos efeitos das condições expostas no i.ten anterior, podem explicar o fato das subpressões, na posição das gallerias de drenagem de montante, se manterem, em vārias observações efetuadas, abaixo do piso das galerias. Este fato se traduz em vazões de drenagem pro funda, relativamente pequenas na galeria de montante, quando compa radas à vazão total das estruturas de concreto. Assim, em Jupiá e em Tha solteira as vazões nas galerias de montante atingem cerca de $20 \%$ do tota], e em Promissão, são desprezíveis. Por outro lado, em relação aos drenos profundos, as meias-canas apresentam uma va zão significativa. Em Jupiä, por exemplo, a vazão coletada pelas meias-canas representa cerca de 608 do total nas galerias de montan te das tomadas d'água e na galeria de jusante da casa de forca. 0 efeito mais significativo deste tipo de drenagem pode sex observado em Ibitinga onde a junta-falha apresenta-se somente drenada por meias-canas na ärea onde foi interceptada pelas escavações da casa de força (veja item seguinte)

IV.3.4. - Condições impostas pela drenagem das casas de força

As casas de força, por necessidades hidräuljcas, são as estru turas que, em geral, requerem maiores profundidades de escavação. As sim, as áreas escavadas em maior profundidade acabam por realizar - papel de um grande poço de drenagem, de escala regional. As des continuidades basálticas mais profundas, interceptadas nessas āreas e drenadas, seja por meias-canas ou por drenos, se transformam em verdadeiros annos plams que exercem importante função de drenagem nas fundações das estruturas de concreto vizinhas, sobretudo quando os drenos, nestas āreas, atravessam vārias descontinuidades atẹ a tingir o drono plano natural. Desta maneira, estabelece-se uma rede de fluxo, paralela ao eixo da barragem, atraía pelas areas dre 
nadas das casas de força. O efeito dessa drenagem se traduz não só en termos de vazões mas tambëm em subpressões. Em promissão, excluin do-se o sistema especial dé drenagem da eclusa, mais de $90 \%$ da va zäo das estruturas de concreto é coletada na casa de força. Nas cá sas de força de Jupiá, atingem $70 \%$ do total. Em seção paralela ao eixo da barragem de Ibitinga, a configuração da linha piezométrica da junta-falha, drenada somente na casa de força, mostra nitidamen te esse efejto (figura 47). O mesmo pode ser observado em Promissão (figura 49).

Por outro lado, em rlha solteira, por razöes geolögicas, to das as estruturas de concreto foram fundadas aproximadamente numa mesma cota (entre 260 e $253 \mathrm{~m}$ ). A area dos vertedores cuja extensão perfaz cerca de $30 \%$ da extensão total das estruturas de concreto a presenta uma vazão de cerca de 50\% do total. As diferenças de vâ zões medidas por estrutura, são devidas, provavelmente neste caso, a razões de ordem geológica. Mas, enfim, Ilha solteira pode ser con siderada um exemplo de ausencia do efeito da drenagem das casas de força, devido suas escavações terem sido executadas até aproximada mente a mesma profundidade nas demais estruturas.

IV.3.5. - A eficiência dos tratamentos

Ao contrário das cortinas de vedação, o desempenho dos drenos tem sido verificado como claramente eficaz no controle das percola ções. A abertura ou fechamento de drenos tem efeitos marcantes nas subpressöes como foi verificado no exemplo de promissão, pela abertura e fechamento do dreno 231 e a resposta imediata das cargas piezométricas do contato por ele drenado (figura 46). Vale assina lar que em Itha solteira a eficiencia dos drenos inclinados (para interceptar as descontinuidades verticais) se mostrou equivalente a 


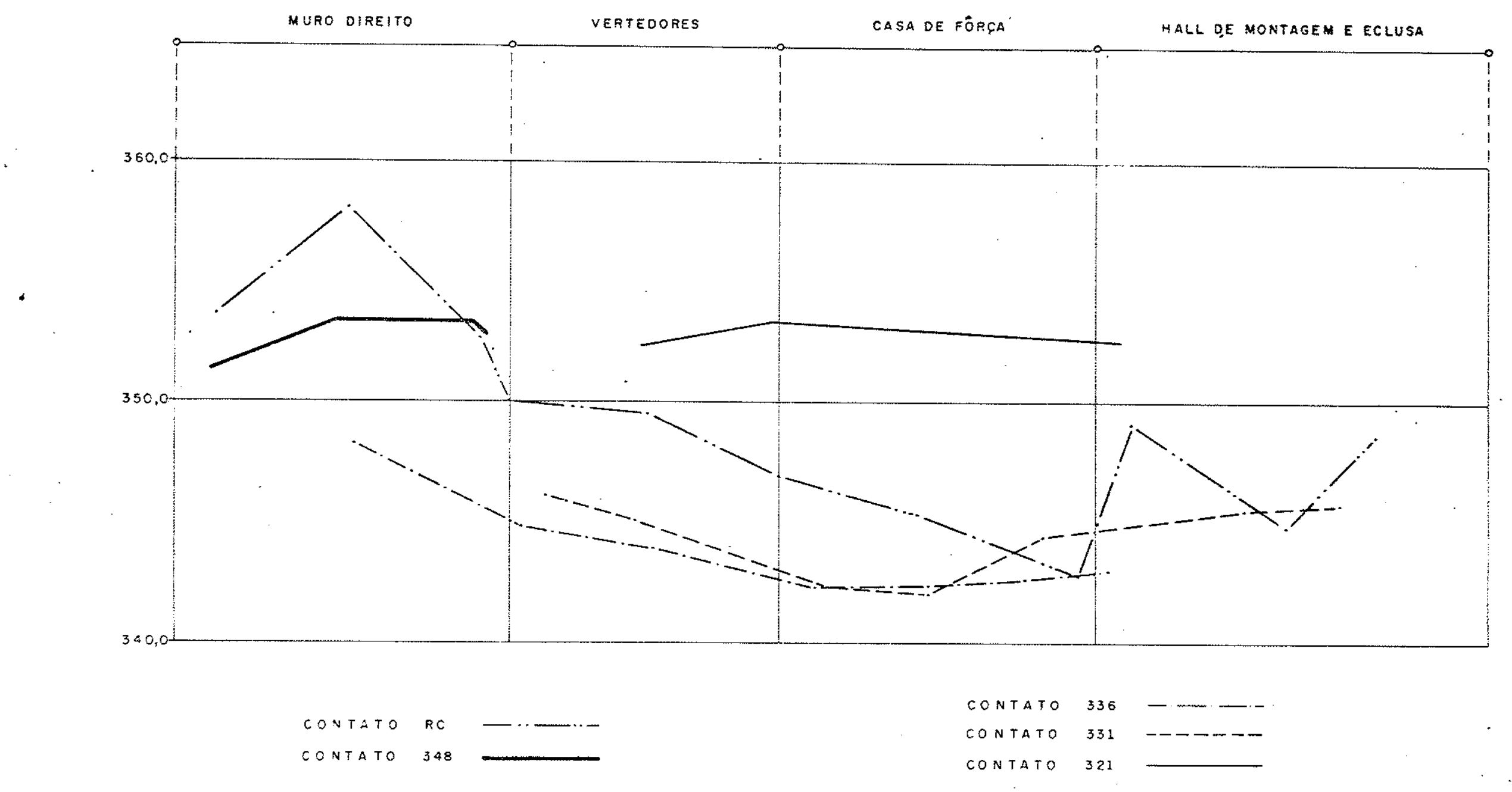

Figura 49 - Linhas piezométricas principais em seção paralela ao eixo da barragem de promissão. 
dos arenos verticais, inaicando que as fraturas verticais, do corpo do maciço compacto, pouca influência tem na percolação (RE, 1976 ).

A eficiência das cortinas de injeção ainda permanece como probloma näo resolvido. Esta situação resulta provavelmente do fato de não se dispor de uma instrumentação instalada em condições propícias para se realizar uma análise segura. Por outro lado, os efeitos dos dre nos são de tal ordem de intensidade e têm tamanho rajo de ação nas descontinuidades basälticas que, provavelmente, mascaram os efeitos de vedação. Nem mesmo nos contatos, descontinuidades de alta injeta bilidade, onde a anảlise das absorções indicam que as injeçöes são eficientes, a eficiência da cortina pôde ainda ser identificada.

A anālise das cargas piezométricas da junta-falha de Ibitinga poderia, em princípio, ser extremamente favorável à identificaçäo da eficiência da cortina, uma vez que esta descontinuidade não se encontra drenada senão na casa de força. De fato, durante o enchi. mento do reservatório foi verificado que, à medida que o nivel d'á gua subia, estabelecia-se um fluxo crescente em cargas piezométri cas na junta-falha a partir da margem esquerda (ärea sem cortina) em direção aos vertedores. Tal fenômeno foi interpretado como sendo resultado dos efeitos da cortina que teria se constituido num ante paro ao fluxo d'ägua de montante. Este fluxo, após contomar a cor tina, se dirigiu por jusante paralelamente ao eixo da barragem, em direção aos vertedores (GUTDICINI, OLIVEIRA e MATUOKA, 1970). contu do, após a execução de drenos na ārea da margem esquerda, este efeito não pole ser mais verificado e as diferenças de carga, medidas atualmente a mon tante e a jusante da cortina não se apresentam superiores a medias equivalentes nos trechos das fundaçōes sem cortina (IPY - Relatório 12.513,1.979). Em Jupiá análises efetuadas nesse sentido levaram os autoros a 
qualificar o papel da cortina como dübio (GUIDICINI e USSAMT, 1969). De maneira a se tentar examinar os efeitos da cortina de veda ção, eliminando-se os efeitos de arenagem, foi realizado um ensaio de fechamento dos drenos profundos dos vertedores de Capivara (SAM PAIO, 1976). Não foi possivel contudo caractexizar uma possivel efi ciência da cortina uma vez que, entre outras razões, as vazões elimi nadas nos drenos fechados da galexia de montante, acabaram por ser redistribuidas por outros drenos a jusante, que permaneceram abertos

Em Ilha Solteira, RE (1976) i.dentificou a eficiência da corti na correlacionando altas vazões nos arenos a jusante com os trechos onde a densidade de furos de injeção foi menor.

IV.3.6. - Comparação com as hipóteses de subpressão

A anālise das cargas piezométricas nos maciços basālticos de fundação mostra dois tipos de comportamento diferentes em relação às hipöteses de subpressão. Um refere-se ao contato $R C$ e outro às descontinuidades de grande extensão, contatos e junta-falha.

No contato $\mathrm{RC}$, a distribuição de cargas segue aproximadamente a configuração das linhas de projeto. Este fato pode ser interpreta do considerando-se que a zona contígua a este contato é em geral constituída por basaltos selecionados pelo projeto para condiçōes mais favorä.m veis de fundação, podendo sex comparado a um meio homogêneo, contínuo e isótropo, e que a influência das descontinuidades basálticas situadas abaixo deve ser míni ma. Contudo, as cargas medidas apresentam-se em geral bastante inferiores às hipóteses e identifica-se uma certa perda de carga a montante, na zona onde a hipotética fenda de tração transmitiria a carga total do reservatório (veja item IV.3.7 a seguix).

Nos contatos e junta-fa]ha instrumentados, a distribuição das cargas é totalmente diversa da configuração das linhas do projeto. As figuras 50 e 51 apresentam respectivamente a situação piezométri 


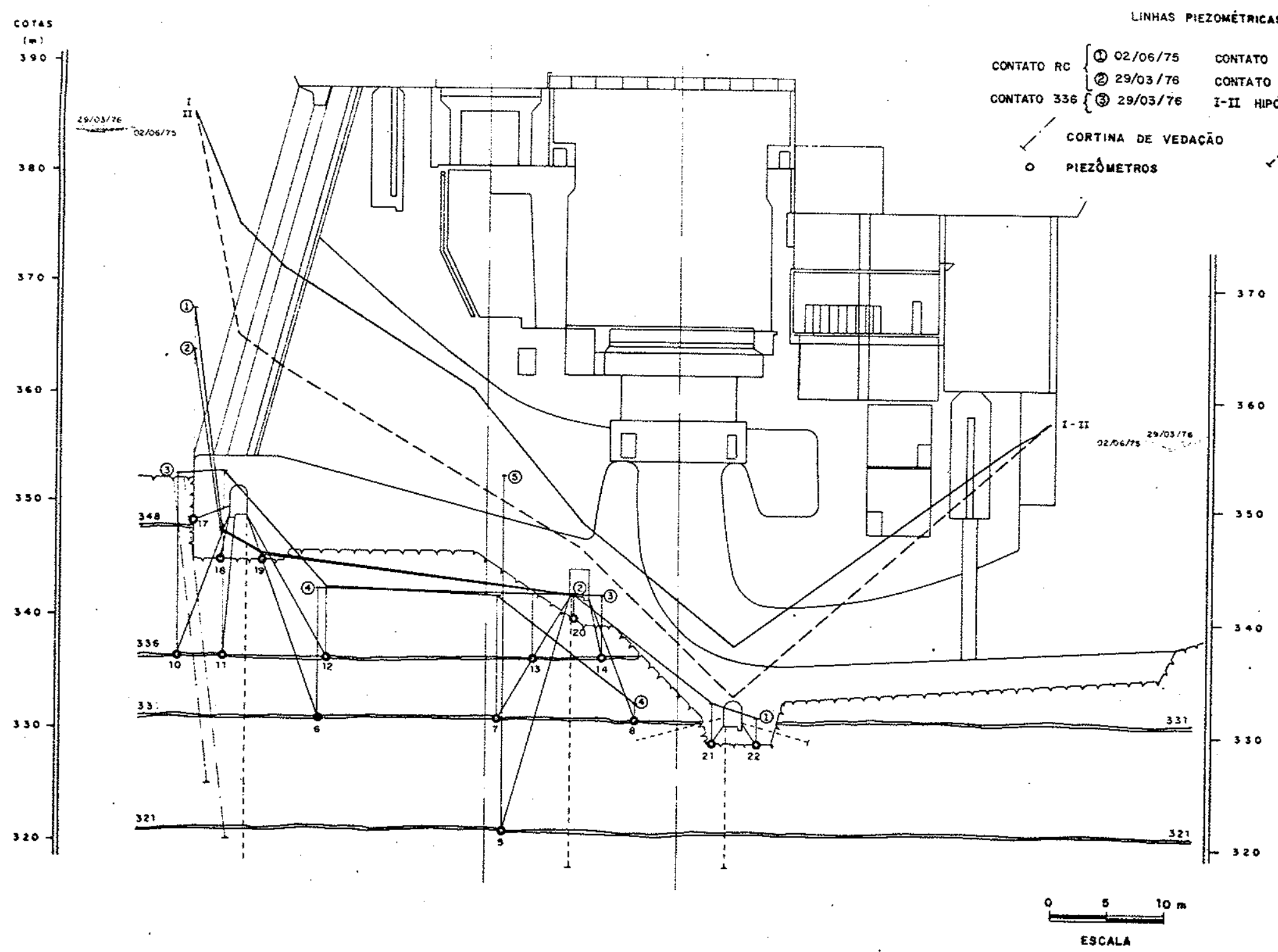

Figura 50 - Linhas piezométricas na casa de força da barragem de Promissão (Oliveira e Correia Filho, 1976). 

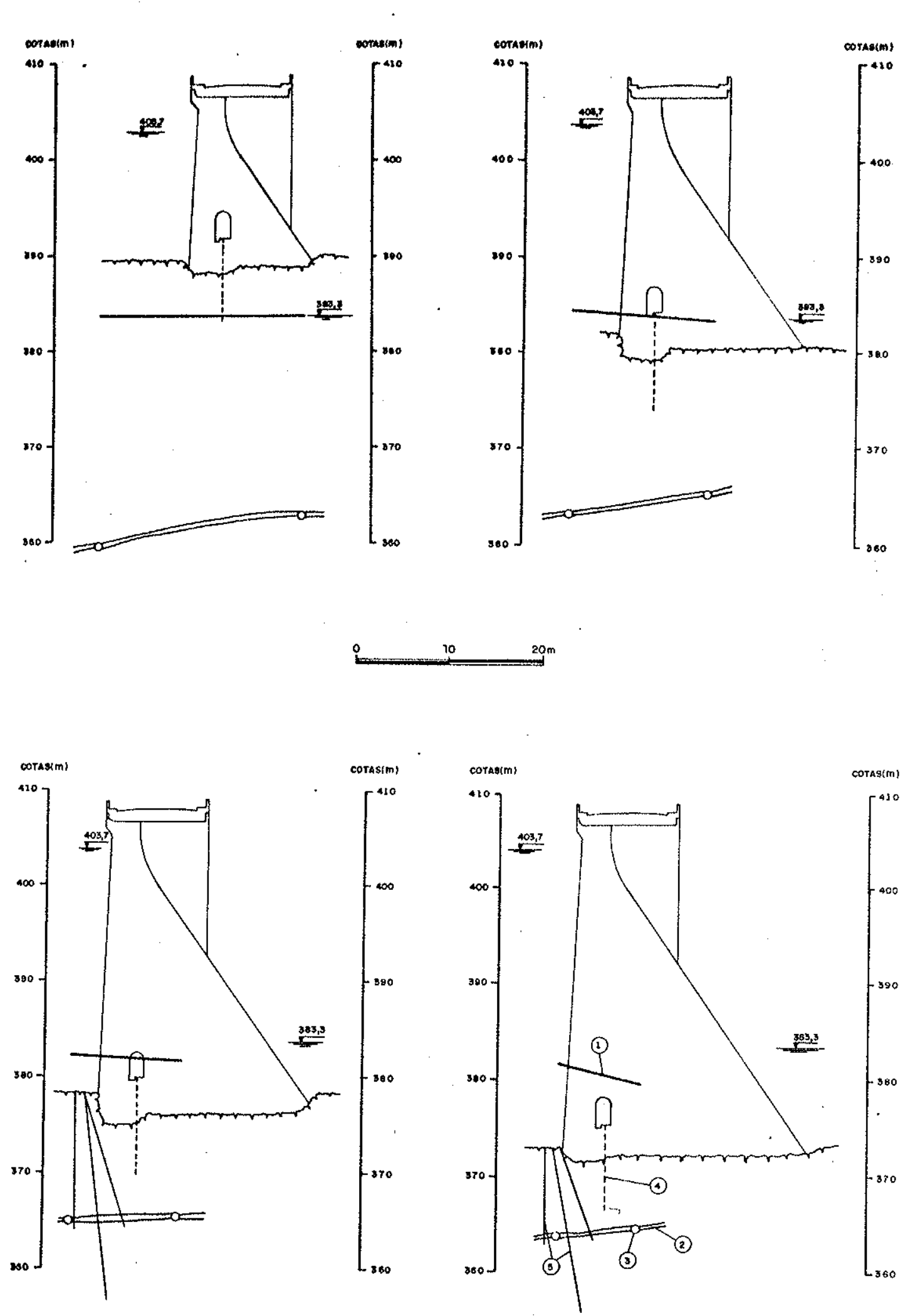
(1) linha piezométrica medida
(2) junta-faiha
(3) piezômetro

(4) dreno

(5) furos da cortina de vedação

Figura 51 - Quatro seções piezométricas da junta-falha de Ibitinga no muro direito (medidas em 13/07/77). 
ca de växios contatos na casa de força de Promissão e as cargas na junta-falha de Ibitinga em värias seções do muro direito. A análise deste comportamento sugere que as cargas piezomëtricas, bastante re baixadas sob as estruturas de concreto, devem permanecer assim até värias dezenas ou talvez centenas de metros sob o reservatório. Es te fato é compatível com as propriedades hidrogeotēcnicas de tais descontinuidades quando as mesmas encontram-se abrigadas de uma a limentação direta do reservatório por uma camada importante de ba saltos compactos praticamente impermeáveis.

IV.3.7. - Comportamento hidrogeotécnico dos basaltos na zona de tra ção

A hipótese da ocorrência desta zona de tração constitui um cri tério de grande peso na elaboração dos projetos das barragens de gravidade. Sua observação depende da existência de uma instrumentação adequada a esse fim. Infelizmente, são poucas as barragens que dispõem de tal instrumentação. Os casos observados envolvem o conta to da rocha com o concreto, ao longo do paramento de montante, e descontinuidades profundas a montante dos tratamentos.

\section{a. - Observações no contato rocha $x$ concreto}

Estas observações foram feitas somente nas barragens de Ilha Solteira e Promissão. A tabela apresentada na pägina seguinte mostra os resultados dessas observações.

Em Ilha Solteira, RE (1976) interpreta a quela observada nas cargas pelos efeitos possíveis das injeções de colagem (ou ligação) onde executadas com maior intensidade, (muros de ligação). 
OBSERVACÖHS PIEZOMETJTCAS NA ZONA DE TRACÃO (CONAATOS R/C)

\begin{tabular}{|c|c|c|c|c|c|}
\hline BARRAGEM & ESTRUTURA & $P(m)$ & $\mathrm{H}(\mathrm{m})$ & $h(m)$ & $\mathrm{h} / \mathrm{H}$ \\
\hline \multirow[b]{3}{*}{$\begin{array}{l}\text { ILHA SOL } \\
\text { TEIRA }\end{array}$} & Muro Direito & $\begin{array}{l}18,0 \\
18,0 \\
18,0 \\
\end{array}$ & $\begin{array}{l}70 \\
70 \\
70 \\
\end{array}$ & $\begin{array}{l}61 \\
43 \\
30 \\
\end{array}$ & $\begin{array}{l}0,87 \\
0,61 \\
0,43 \\
\end{array}$ \\
\hline & Muro Esquerdo & $\begin{array}{l}15,0 \\
15,0 \\
\end{array}$ & $\begin{array}{l}67 \\
67 \\
\end{array}$ & $\begin{array}{l}60 \\
61 \\
\end{array}$ & $\begin{array}{l}0,89 \\
0,9.1 \\
\end{array}$ \\
\hline & Tomada d'āgua & $\begin{array}{l}17,2 \\
17,1 \\
17,5 \\
19,2\end{array}$ & $\begin{array}{l}69 \\
69 \\
69 \\
71 \\
\end{array}$ & $\begin{array}{l}38 \\
10 \\
56 \\
41 \\
\end{array}$ & $\begin{array}{l}0,55 \\
0,14 \\
0,81 \\
0,58 \\
\end{array}$ \\
\hline \multirow{2}{*}{ PROMISSÃO } & Vert.de Superf. & $\begin{array}{l}20,3 \\
20,3 \\
\end{array}$ & $\begin{array}{l}72 \\
72 \\
\end{array}$ & $\begin{array}{l}68 \\
69 \\
\end{array}$ & $\begin{array}{l}0,94 \\
0,96\end{array}$ \\
\hline & $\begin{array}{l}\text { Vert. de fundo } \\
\text { Tomada d'ägua }\end{array}$ & $\begin{array}{l}5,6 \\
3,8\end{array}$ & $\begin{array}{l}35,4 \\
35,2\end{array}$ & $\begin{array}{l}22,0 \\
16,2\end{array}$ & $\begin{array}{l}0,62 \\
0,46\end{array}$ \\
\hline
\end{tabular}

P - profundidade do piezômetro em relação ao fundo : do reservatório.

H - carga esperada no piezômetro considerado tránsmissão total da coluna d'água do reservatório.

h - carga efetivamente medida.

Em Ilha Solteira, RE (1976) interpreta a queda observada nas cargas pelos efeitos possiveis das injeções de colagem (ou ligação) onde executadas com maior intensidade (muros de ligação).

Contudo, somente as medidas de cargas piezomētricas não caracterizam. o comportamento hidrogeotécnico da zona en questão. Informações mais detalhadas so bre tal comportamento foram apenas obtidos en promissão e apresentadas por ol. I VEIRA e CORREIA FILHO (1976): os piezômetros instalados nessa zona apresentam um comportamento diferente dos demais, ou seja, são mito sensiveis a qualquer va riação do nivel de montante. A resposta destes piezômetros è maior que a própria amplitude de variação do nível de montante e, quando abertos, apressentam uma vâ zão muito reduzida (gota a gota).

b. - Observacões em descontinuidades profundas

As observações do comportamento piezométrico nestas desconti nuidades foran feitas apenas em Ibitinga e Promissão. A tabela a se guir apresenta os resultados destas observações: 
OBSERVAÇŌES PIEZOMETRICAS NA ZONA DE TRAÇÃO (DESCONITNUIDADES PROFUNDAS)

\begin{tabular}{|c|c|c|c|c|c|}
\hline BARRAGEM & ESTRUTURA & $\mathrm{P}(\mathrm{m})$ & $\mathrm{H}(\mathrm{m})$ & $h(m)$ & $\mathrm{h} / \mathrm{H}$ \\
\hline \multirow[b]{2}{*}{ IBITINGA } & $\begin{array}{l}\text { Muro Direito } \\
\text { (figura 51) }\end{array}$ & $\begin{array}{r}30 \\
19 \\
13 \\
9 \\
\end{array}$ & $\begin{array}{l}43 \\
40 \\
39 \\
40 \\
\end{array}$ & $\begin{array}{l}24 \\
21 \\
17 \\
18\end{array}$ & $\begin{array}{l}0,56 \\
0,52 \\
0,44 \\
0,45 \\
\end{array}$ \\
\hline & Muro esquerdo & $\begin{array}{l}24 \\
19 \\
18 \\
\end{array}$ & $\begin{array}{l}50 \\
45 \\
45 \\
\end{array}$ & $\begin{array}{l}31 \\
20 \\
27 \\
\end{array}$ & $\begin{array}{l}0,62 \\
0,44 \\
0,60\end{array}$ \\
\hline \multirow[b]{2}{*}{ PROMISSÃO } & Vert.de superf. & $\begin{array}{l}10 \\
10\end{array}$ & $\begin{array}{l}41 \\
41\end{array}$ & $\begin{array}{l}23 \\
22\end{array}$ & $\begin{array}{l}0,56 \\
0,54\end{array}$ \\
\hline & $\begin{array}{l}\text { Muro Direito } \\
\text { Vert. de fundo } \\
\text { Tomada d'ägua } \\
\text { (figura } 50 \text { ) }\end{array}$ & $\begin{array}{r}6 \\
18 \\
18\end{array}$ & $\begin{array}{l}36,0 \\
48,4 \\
48,4\end{array}$ & $\begin{array}{r}7,0 \\
17,6 \\
15,4\end{array}$ & $\begin{array}{l}0,19 \\
0,35 \\
0,32\end{array}$ \\
\hline
\end{tabular}

c. Anälise das observações efetuadas

As observações efetuadas no contato rocha-concreto sugerem que as tensões de tração provocariam a formação de fissuras ou abertura das prē-existentes (naturais, resultantes do uso de explosivos ou do alívio de tensões do maciço pela escavação). A abertura dessas fissuras deve ser de tal ordem que permitiria apenas uma reduzida percolação. Em Promissão o comportamento dessas fissuras foi in terpretado da seguinte forma: "Pode-se admitir que essas fissuras, por serem muito finas devem ser muito sensiveis a qualquer solicitagão me cânica. Tudo leva a crer que qualquer variacão do nivel de montante, provocando alteragão do empuxo a'ägua na barragem, resulta em defor magões do macigo rochoso sendo estas deformagões resultado da aber tura ou fechamento das referidas fissuras. Assim, as cargas piezomé tricas resultariam ampliadas pela conjugąão de dois fenómenos: um mecânico e outro hidräulico. No caso, por exemplo, de um rebaixamen to do nivel de montante: hidraulicamente haveria uma reduça da car ga total, ao mesmo tempo em que o fechamento das fissuras provoca ria uma maior perda de carga d'ägua de percolacão, resultando, por fim, numa queda de carga piezométrica maior que o próprio estimulo originai". (OLIVEIRA e CORREIA FILHO, 1976).

Os valores variāveis da relação $\mathrm{h} / \mathrm{H}$ poderiam ser dos como sendo resultantes da não formação de um plano interpreta continuo, 
aberto ao longo do paramento de montante.

Mesmo que as descontinuidades profundas fossem atingidas por tais fissuras provavelmente seus efeitos seriam despreziveis frente a boa drenabilidade que as descontinuidades oferecem, como sugerem os valores $\mathrm{h} / \mathrm{H}$ medidos nessas descontinuidades.

\section{V. - CONCLUSÕES}

A metodologia proposta revela-se adequada ao estudo da perco lação d'āgua em macjeços rochosos para o projeto de grandes barra gens. Esta metodologia ultrapassa porém o próprio assunto examinado, po dendo servir como um referencial científico básico a outros estudos de Geologia Aplicada às obras de Engenharia Civil. Compõem este refe rencial, de um lado, as solicitações que tais obras exercem no meio físico e, de outro lado, as qualidades desse meio físico, que se co locam como respostas às solicitaçöes. O meio físico deve ser identi ficado cientificamente segundo as orientações da Geologia: a forma ção, seu espaço geogräfico de ocorrência, os aspectos geológicos, geomorfológicos e hidrogeológicos daí decorrentes e, no estudo obje to da tese, o comportamento hidrogeotécnico dos basaltos.

Em seguida ao estabelecimento do referencial científico e 으 rientado por este, a metodologia proposta destaca a análise da experiên cia adquirida que leve a um estudo de sintese do comportamento do sistema (obra $x$ meio fisico) que, no presente trabalho, se traduziu pe lo sistema (barragem x formação).

A aplicação da metodologia ao caso especifico (barragem do ti po gravidade x Formação Serra Geral) se revelou frutifera ao exami nạx, em bases geolōgicas, o problema da pexcolação d'água em funda çöes de grandesbarragens cuja anälise, em bases genéricas, aiscuti

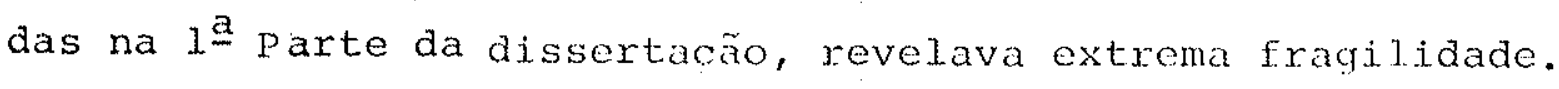


Os principais resultados da aplicação da metodologia são em seguida destacados.

V.1. - Os basaltos

Os basaltos da Formação Serra Geral possuem um comportamento hidrogeológico peculiar, determinado por algumas caracte risticas prōprias de rochas İneas intrusivas (porosidade de fratu ras, embora de gêneses diversas) e de rochas sedimentares não dobra das (estratificação e sub-horizontalidade de seus planos preferenciais de perco lação, como as juntas sedimentares subparalelas à estratificação).

No interior da formação, a seqüencia de derrames superpostos. define os contatos como a principal descontinuidade, de alta per meabilidade, formando aquíferos confinados e constituindo franco caminho preferencial de percolação. Dentro de cada derrame podem $O$ correr descontinuidades de importância equivalente e caracterizadas como juntas horizontais de grande extensão ou juntas-falhas. As va riedades de basalto compacto ou vesicular, com fraturamento ver tical, são essencialmente pouco permeáveis, podendo ser considerados im permeäveis em comparação com as descontinuidades acima descritas.os basaltos compactos ou vesiculares com fraturamento horizontal porém sem grande continuidade lateral (extensões inferiores a algumas dezenas de metros) embora possam ter permeabilidades eleva das localmente, não favorecem a circulação d'ägua no corpo dos der rames.

Este quadro de distribuição de permeabilidades, fortemente a nisotrópico e descontínuo, persiste a crandes profundidades, ao con trärio dos maciços intrusivos, conforme esquematicamente apresenta do na figura 52.

Nos leitos dos rios, subsistem em geral os basal tos compactos mais resistentes, capeando litologias mais erodiveis 
Maciços bosólticos

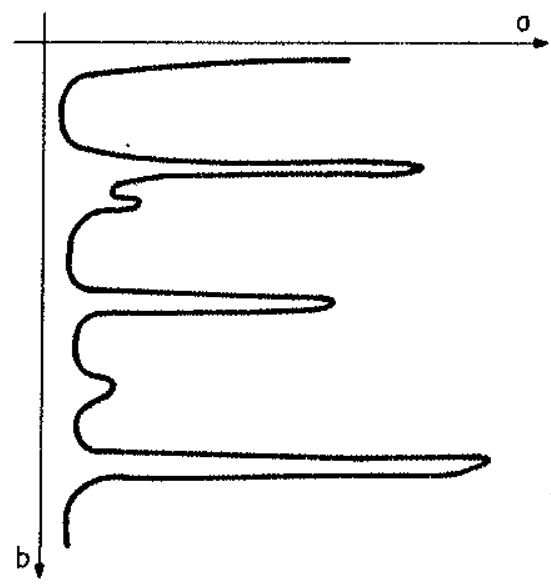

Maciços intrusivos

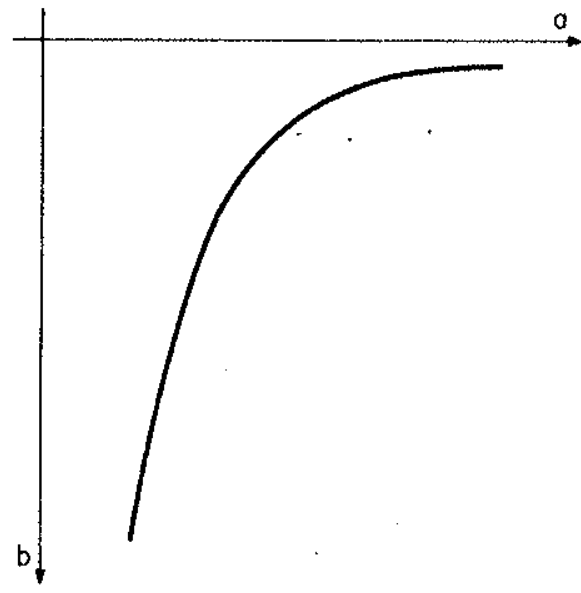

permeabilidade (a) e profundidades (b) crescentes no sentido indicado nos gráficos.

Figura 52 - Comparação teōrica das distribuições da permeabilidade, em profundidade, entre os maciços basälticos e os in trusivos (OLIVETRA, SILVA e GUIDICINI, 1976). 
como as que constituem o topo dos derrames.

\section{V.2. - As barragens}

As estruturas de concreto das barragens de gravidade analisa das, cujos projetos foram adaptados a uma série de condições do meio físico da bacía do Paraná, são construídas nos leitos dos rios, onde as casas de força exigem escavações mais profundas que as das demais estruturas.

Relativamente ao controle das percolações d'água nas fundạ ções, os projetos foram realizados considerando critérios e regras genéricas para a adoção de hipóteses de subpressão, que não podem levar em conta as feições geológicas que ocorrem em cada local.

As escavações realizadas, no início da construção, constituem a primeira solicitação significativa da obra ao meio físico. guidas pela concretagem dos blocos, a etapa de construção pode ser considerada do ponto de vista hidrogeotécnico, como um ensaio, na escala da obra, do maciço de fundação.

\section{V.3. - O sistema barragem $x$ basalto}

Durante a etapa de construção as observações hidrogeotécnicas efetuadas ter sido raras e meramente qualitativas. Durante a concretagem. ressalta-se a experiência realizada em Promissão através de ensaios denominados hidrogeotécnicos globais por envolverem toda a fundação das estruturas de concreto.

A execução das injeções ressalta a elevada injetabilidade dos contatos e juntas de grande extensão. O comportamento das litologias basālticas e do contato RC, frente às injeções, sugere que o trata mento, seria plenamente dispensāvel na maioria destes casos. Contudo a eficiência da vedação nas descontinuidades importantes permanece por ser mais fxequentemente constatada e sobretudo quantificada.

As alterações do quadro hidrogeotécnico, impostaspela execu 
Ção da drenagem, durante a construção, nas descontinuidades impor tantes, sugere a exigência de um limite de drenabilidade, traduzi do pela instalação de novos drenos que produzem rebaixamentos de cargas piezomëtricas sucessivamente menores, o que é compatível comas caracteristicas hidrogeotēcnicas das descontinuidades.

Com o enchimento do reservatório, verifica-se a grande impor tância do papel de tais descontinuidades ao realizarem uma intensa drenagem das fundações em toda sua área de ocorrência. o papel des tes drenos planos naturais é condicionado não só pelas caracteristi cas hidrogeotēcnicas das descontinuidades mas sobretudo quando isoZadas do reservatório, ocorrendo sob basaltos praticamente impermeáveis.

Esta capa de basaltos, no reservatório, pode ser assemelha da aos tapetes impermeáveis que, na Engenharia, constituem alterna tiva à vedação por injeções. Portanto, o quadro geral das caracte risticas e comportamentos hidrogeotécnicos dos basaltos traz em si os elementos a serem aproveitados no controle das percolações: tape tes a montante e drenos planos sob a barragem.

Estas condições, alteradas nas fundações por uma sērie de ele mentos construtivos (interligação das descontinuidades por arenos profundos, drenagem superficial por meias-canas, drenagem profunda. das casas de força) permitem interpretar a distribuição real. das subpressões, abaixo do contato RC, cuja configuração não se asseme lha às linhas piezométricas de projeto. A anälise dos comportamentos hidrogeotécnicos tendo em vista os diferentes condicionantes basál ticos, diversidade esta multiplicada pelos condicionantes impostos. pela obra, resiste à adoção de regras genéricas de projeto.

o comportamento observado na zona de tração mostra que no con tato $\mathrm{RC}$, as cargas podem atingix os valores máximos impostos pelo 
reservatório. Nas decontinuidades profundas observadas, os efeitos da zona de tração não são significativos.

V.4. - Conclusões finais

Os ganhos, tecnológicos e científicos, obtidos com a aplica ção da metodologia podem ser destacados sob dois aspectos princí pais:

19) As vārias experiências adquiridas no estudo do comportamento hidrogeotécnico dos basaltos, como fundação de barragens do tipo gra vidade, foram analisadas criticamente e sintetizadas em comportamen tos tipicos ou comuns às värias experiências, consistentes com o re ferencial cientỉfico adotado.

29) A realização deste estudo permitiu identificar lacunas do conhe cimento e problemas persistentes que, se adequadamente formulados e analisados, poderão vir a ser resolvidos. E o que se procura fazer na 4 - Parte desta tese. 


$$
\underline{4} \stackrel{\underline{a}}{-} \mathrm{P} \quad \mathrm{A} \quad \mathrm{R} \quad \mathrm{T} \quad \mathrm{E}
$$

TENDENCIAS NA EVOLUÇÂO DA HIDROGEOTECNTA DE BARRAGENS 


\section{I. - INTRODUCR̃O}

As considerações que se seguem resultam de reflexões sobre a integração das conclusões obtidas na $1^{a}$ e 3 a Partes da dissertação.

Recordando as conclusões da $l$ â Parte, observou-se a necessidade do meio técnico envidar esforços no sentido de melhor orientar os estudos hidrogeotécnicos de campo, cujo desenvolvimento encontra-se atrasado em relação aos progressos feitos nos estudos teóricos e nos modelos da análise pois tanto uns quanto outros dependem intrinse camente dos estudos de campo. Aquelas conclusões indicavam tambëm que a análise dos problemas hidrogeotécnicos, sobretudo os referentes à vedação e suas injeções, requeria um enfoque orientado por uma metodologia precisa, de manejra a não se perder em generalidades inūteis e mes mo perigosas ou, por outro lado, não se limitar a experiência adqui. rida exclusivamente aos respectivos casos especificos.

Na 2 a Parte, foi proposta uma metodologia visando superar os obstáculos anteriormente assinalados. O enfoque metodológico propos to resultou do estabelecimento de um referencial de anälise defini do por 3 coordenadas principais:

- a obra (as solicitações)

- o meio físico (as respostas possíveis)

- o sistema obra $x$ meio físico lo comportamento interativo - sín tesé das experiências).

Ressaltou-se nesta proposição a retomada dos principios e fun damentos da Geologia no estudo do meio físico e no desenvolvimento desté referencial, tendo em vista a própria evolução da Geologia de Engenharia no país e suas tendências atualmente em jogo.

Por fim, a aplicação desta metodologia na 3 a $^{2}$ parte da dissertação, no caso escolhido das barragens de gravidade sobre basaltos, resultou numa série de conclusões que, agora, devem ser observadas juntamen 
te com os da $1^{\underline{a}}$ parte.

primeiramente, ressalta-se, nas conclusões da 3 a parte, a i dentificação de um obstáculo importante ao pleno desenvolvimento da Hidrogeotecnia em seu trabalho de campo cuja necessidade foi apon

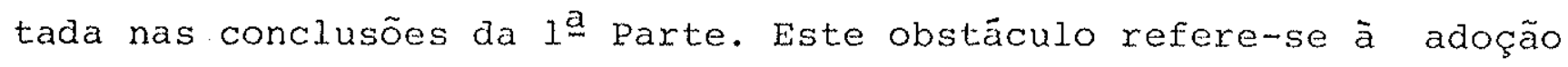
de regras preconcebidas de projeto e pode ser traduzido pela ques tão: até que nível são necessários os estudos hidrogeotēcnicos para - projeto de uma barragem enquanto se continua a adotar tais re gras?

Contudo, como abandonar as regras de projeto sem uma alternati va viável e segura que produza resultados técnica e economicamente superiores?

Nesta questão fecha-se um ciclo vicioso importante: uma nova metodologia de projeto sö pode ser aplicada quando os estudos hidro geotécnicos puderem ser levados a suas últimas consequências, ou se ja, à previsão do comportamento. Contudo não podem ser levados até essa previsão enquanto as regras de projeto permanecerem como obstá culo ao pleno desenvolvimento de tais estudos.

o exame adequado destas questões exige que as mesmas sejam de vidamente colocadas num contexto muito mais amplo, técnico-econômi co, em que se leve em conta inclusive a ponderação dos principais en fogues em jogo: da proprietāria da obra, do projetista e do emprei teiro.

Como este trabalho não tem tal pretensão, pode-se apenas analisar algumas alternativas da evolução do problema, visando tão somente colaborar para sua elucidação futura.

A primeira alternativa que pode ser levantada seria supor que, na realidade, a questão não se coloca. ou seja, o dilema do ciclo vicioso seria falso, pois as barragens estäo al sendo construỉdas e aparentemente não estão a exigir nenhum aprofundamento maior 
questão. Desta maneira, não haveria porque envidar esforços no sen tido de quebrar o ciclo vicioso. A possibilidade de evolução da . Hi drogeotecnia de barragens somente poderia se dar através da anālise de casos especificos, que escapassem a comportamentos médios, ou a través da solução de problemas parciais de fundação.

Outra alternativa seria considerar a necessidade de se buscar um melhor conhecimento dos comportamentos hidrogeotécnicos dos maciços, que per mita o contínuo aperfeiçoamento das anälises de estabilidade e consequentemente dos projetos. E dentro desta alternativa que são desenvolvidos os itens seguintes desta 4. ${ }^{\text {a }}$ Parte.

\section{II. - ORIENTAÇOEES PARA OS ESTUDOS HIDROGEOTECNICOS E A PREVISÃO DAS SUBPRESSÕES E DAS VAZÕES}

Dispõe-se atualmente de tēcnicas que permitem caracterizar ple namente o quadro hiarogeotécnico de um local para o projeto de bar ragens. Por outro lado, pode-se determinar, com relativa precisão, as solicitações impostas pelas barragens do tipo gravidade. Assim, a aplicação de um estudo de modelos de análise ao problema poderia alcançar a previsão do comportamento do sistema (barragem $\mathrm{X}$ fundações) em termos de subpressões e vazões, permitindo assim prever o comportamento hidrogeotëcnico durante e após o enchimento do reservatório e orientar adequadamente o projeto dos tratamentos.

la 8,que exigem a aplicação das tẻcnicas relacionadas na tabela 9, os estudos hidrogeotécnicos deveriam prosseguir desde o projeto até - enchimento do reservatório. Durante a etapa de construção, os es tudos sofreriam um salto qualitativo importante, propiciado pela realização das escavações e concretagens, cujo papel, jā caracte rizado, pode ser traduzido pela primoira aferisäo do mode lo de comportamento hidrogeotécnico, estabelecido na etapa anterior. 


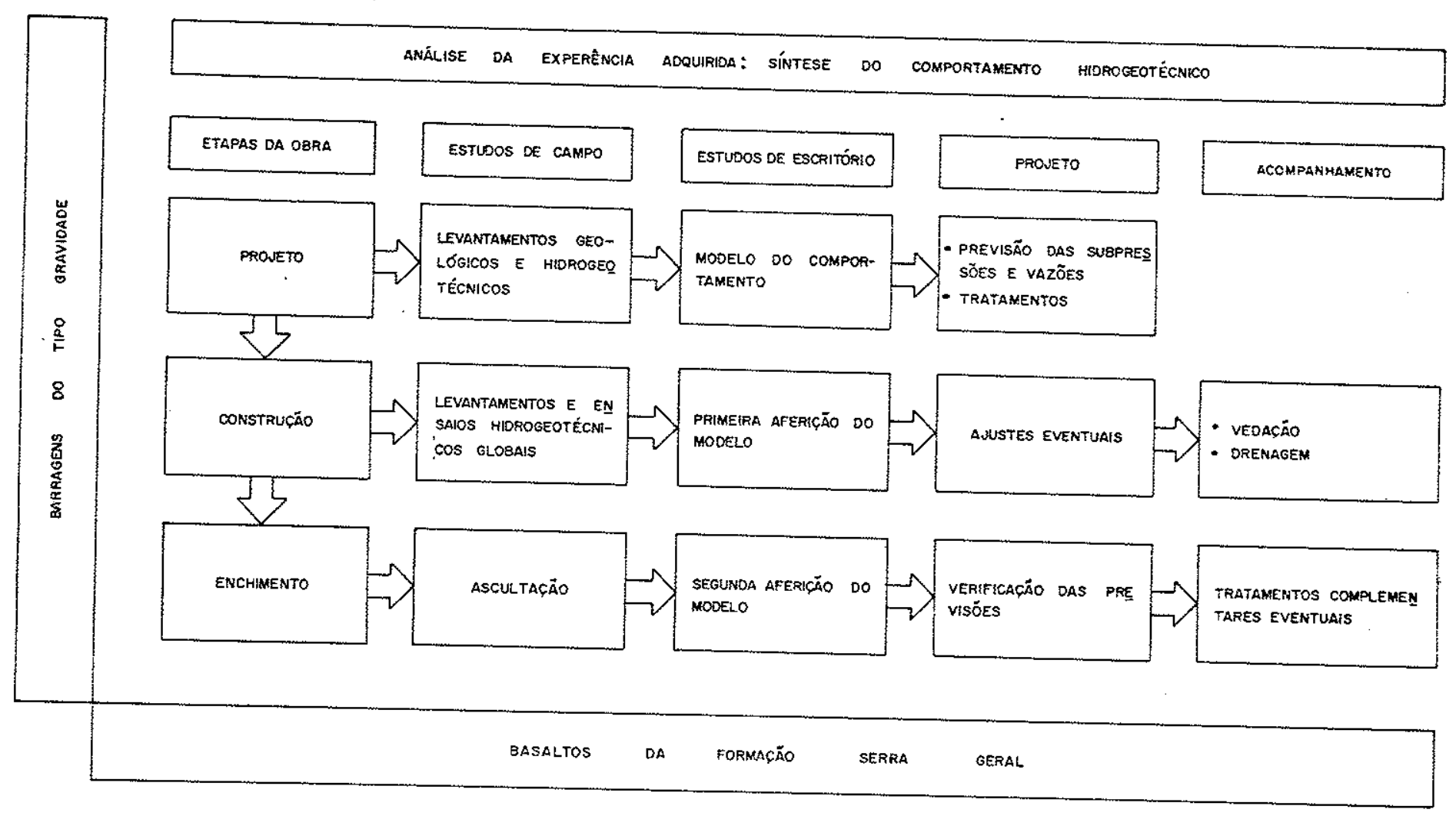

Tabela 8 - Orientações para os estudos hidrogeotécnicos. Exemplo para os casos de barragens de gra vidade sobre basaltos da Formação Serra Geral. (Modificado de AZEVEDO, OLIVEIRA e SCARES, 1978). 


\begin{tabular}{|c|c|c|c|}
\hline & TÉCNICAS DE CAMPO & TÉCNICAS OE ESCRITÓRIO & OBJETIVOS \\
\hline $\begin{array}{l}0 \\
\underline{L} \\
\vec{z} \\
0 \\
\frac{\sigma}{a} \\
a\end{array}$ & 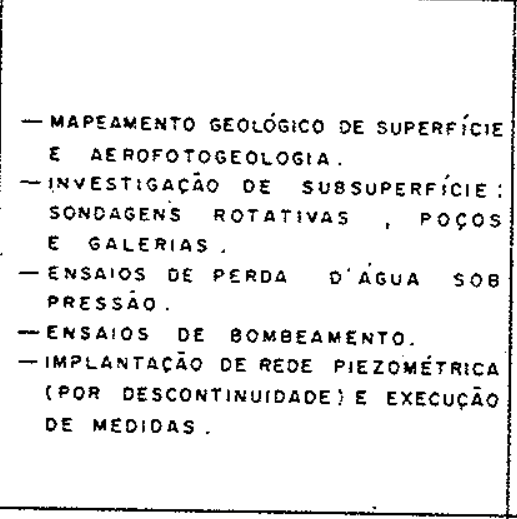 & 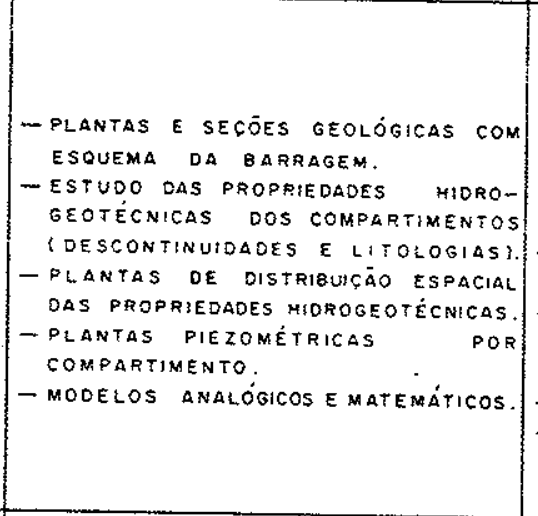 & 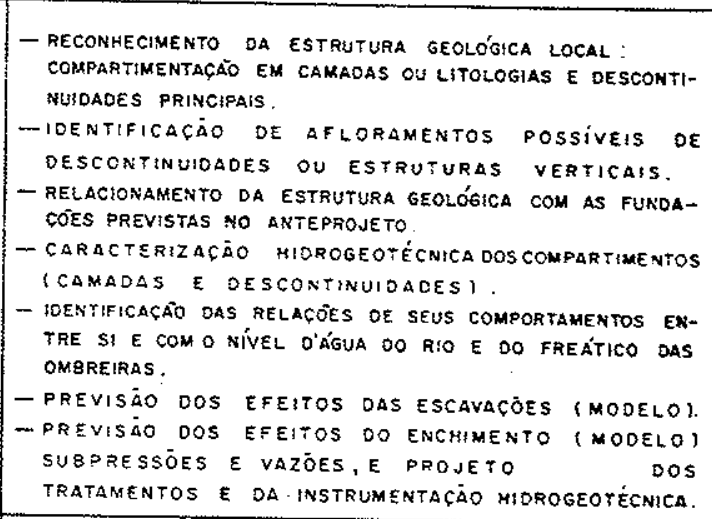 \\
\hline 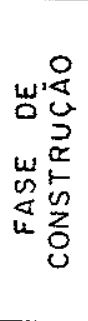 & 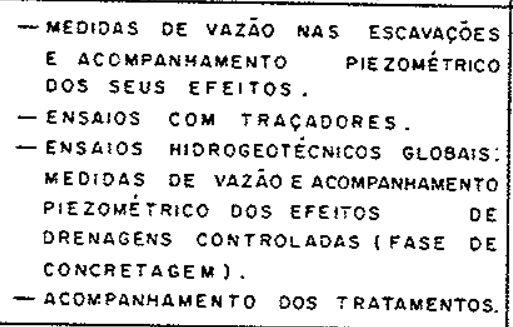 & $\begin{array}{l}\text { - GRÁICOS DE VAZOES E CARGAS } \\
\text { PIEZOMÉTRICAS X TEMPO COM IDENTIFICACAOO } \\
\text { DOS PRINCIPAIS EVENTOS CONSTRUTIVOS } \\
\text { - PLANTAS PIEZOMÉTRICAS. } \\
\text { - MODELOS ANALÓGICOS A JUSTADOS AOS } \\
\text { NOVOS CONHECIMENTOS. }\end{array}$ & 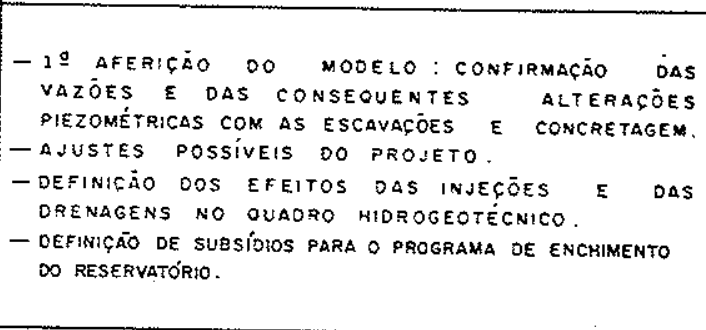 \\
\hline 峞突 & $\begin{array}{l}\text { - AUSCULTACÁAO HIDROGEOTÉCNICA } \\
\text { MEDIDAS DE VAZÁO E . CARGAS } \\
\text { PIEZOMETRICAS. }\end{array}$ & $\begin{array}{l}\text { - GRÁFICOS DE VAZAO E DE CARGAS } \\
\text { PIEZOMÉTRICAS X TEMPOCOM A EVLUUCAOO } \\
\text { DOS NIVEIS DE MONTANTE E UUSANTE } \\
\text { - PLANTAS PIEZOMÉTRICAS. } \\
\text { - MOOELOS ANALOGICOS AJUSTADOS AOS } \\
\text { RESULTAOOS DO ENSAIO EM VEROADEIRA } \\
\text { GRANDEZA. }\end{array}$ & 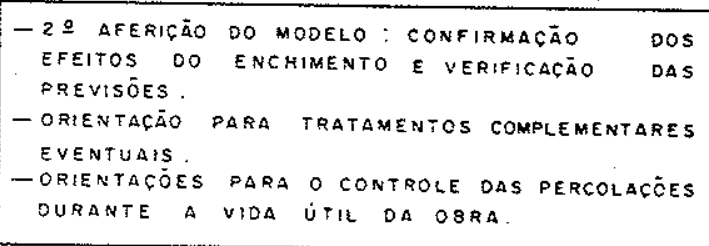 \\
\hline
\end{tabular}

Tabela 9 - Técnicas usadas e respectivos objetivos nás diversas fases da barragem, segundo orientaçäes da tabela anterior (Modificado de AZEVEDO, OLIVEIRA e SOARES, 1978). 
Finalmente, o enchimento do reservatório, ensaio em verdadeira gran dea cuja programação deveria levar tambëm em conta as exigências de um controle seguro das percolações, possibilitaria a segunda afe rigão do modelo, sua verificação final, que poderia revelar a necessidade $\mathrm{E}$ ventual de se executar tratamentos complementares e orientar o controle futuro das percolações durante a vida útił da barragem.

A aplicação destas orientações, especialmente na etapa de pro jeto de uma barragem, permitixia alcançar não só uma substancial economia na realização dos tratamentos das fundaçöes, sobretudo nas injeções de vedação, e na operação das bombas de esgotamento da ā gua drenada, mas sobretudo alcançar um grau de segurança da obra melhor co nhecido, portanto mais confiāvel, e um conhecimento adequado do comportamento das percolações nas fundações, portanto seu controle mais adequado durante a vida [atj]. da obra.

As orientações propostas ressaltam o principal problema a re solver que consiste na previsão das subpressões e vazões e o princi. pal instrumento de solução que consiste nos modelos de análise. Este é o quadro que poderia se.contrapor à adoção de critérios genéricos de projeto, cujo elemento-chave, constituỉdo pela adoção da hipótese de fendas de trasão, deveria também ser submetido ao exercício da previsão. Assim, nos itens seguintes discute-se, mais detalhadamente, os estudos necessários à previsão do comportamento das fundações na zona de tração e os modelos de análise.

II.1. - Previsão do comportamento das fundações na zona de tração

A anälise deste comportamento, efetuada no j.tem IV.3.7. da 3 a Parte da tese, indiça que no contato $R C$, as cargas podem atingir os valores máximos condicionados pelo nível do reservatörio.

Nos casos observados nas descontinuidades profundas, é fato que os efeitos da zona de tração não se fazem sentir, supondo-se 
que as fissuras abertas nessa zona são de tal ordem (microfissuras) que sua propagação em profundidade, se ocorrer, não altera o compor tamento hidrogeotécnico das descontinuidades, sobretudo quando subme tidas a arenagem a jusante. Provavelmente tais fissuras, não se propagariam em profundidade, ou pelo menos seriam bastante atenua das, além da primeira descontinuidade ou camada de menor resistên cia a tração como as que constituem as zonas de topo dos derrames. Esta análise do comportamento sugere que o critério de fendao de tragão coincidiria com o observado apenas no contato RC. Para as descontinuidades profundas o projeto deveria analisar a questão segundo enfoque restrito à obra e fundações específicas, ou seja, o comportamento mecânico do maciço a ser submetido aos esfor çoes pela barragem, prevendo a profundidade e a abertura que tais fissuras atingiriam. Existem técnicas apropriadas ao exercício de tal previsão (modelos geomecânicos).

Por outro lado, considerando-se que os casos observados abai xo do contato RC se limitam apenas a Promissão e Ibitinga, e que a questão encontra-se ainda pouco estudada, ressalta-se a necessida. de de realização de estudos mais aprofundados sobre a zona de tra ção, seus efeitos e suas implicações na estabilidade das barragens.

Tais pesquisas deveriam ser orientadas por programas que com preendessem tanto estudos de laboratório, quanto de campo. Um deles, a titulo de sugestão, poderia ser desenvolvido com o seguinte rotei ro:

- estudos teóricos

- levantamento de dados disponíveis;

- discussões em mesas redondas;

- potencialidades e limitações dos modelos de análise. 
- pesquisas de campo

- anälise e correlação dos comportamentos hidrogeotécnico e mecânico da zona de "tração" em barragens instrumentadas e a instrumentar (critérios de escolha);

- medidas de tensões;

- caracterização geotécnica de algumas zonas de "tração" com amostragem integral e para ensaios de laboratório.

- ensaios de laboratório

- ensaios de permeabilidade ao ar e a água, sob tensões varia veis.

- estudos em modelos de anälise

- distribuição de tensões e de permeabjlidades;

- compatibilização dos modelos aos comportamentos mecânicos e hidrogeotécnicos, medidos no campo e no laboratório.

II.2. - Modelos de anälise

Uma especulação sobre alguns exemplos teöricos, definidos pe la convergência dos aspectos principais da sintese do comportamento. hidrogeotécnico dos basaltos como fundações de barragens do tipo gravidade, é útil para se visualizar a importância da aplicação de modelos matemäticos ou analógicos num caso concreto de estudos para um dado projeto.

A primeira série de modelos diz respeito à etapa de construção da obra, envolvendo a previsão da alteração do quadro hidrogeotẹcni co com as escavações.

A segunda sërie de modelos consideri o enchimento do reservató rio e a previsão do comportamento das percolações, sendo inevitável a discussão sobre o papel dos tratamentos e portanto sua conveniên cia. 
São apresentados dois exemplos teóricos nas figuras 53 e 54 , hi potéticos e simplificados, porém compatíveis com as observações do comportamento das barragens em operação, permitindo identificar as principais questões a serem respondidas pela aplicação dos modelos de análise.

Tendo em vista a necessidade de se tratar a questão não só em modelos bidimensionais mas especialmente tridimensionais, os exem plos estão apresentados em duas seções transversais deslocadas, sen do uma sobre estruturas de fundação rasa (como os muros de ligação) e outra sobre estrutura de fundação profunda (como as casas de for ça). O esquema abaixo explica a apresentação das seções:

12) Definiç6o das segões em planta.

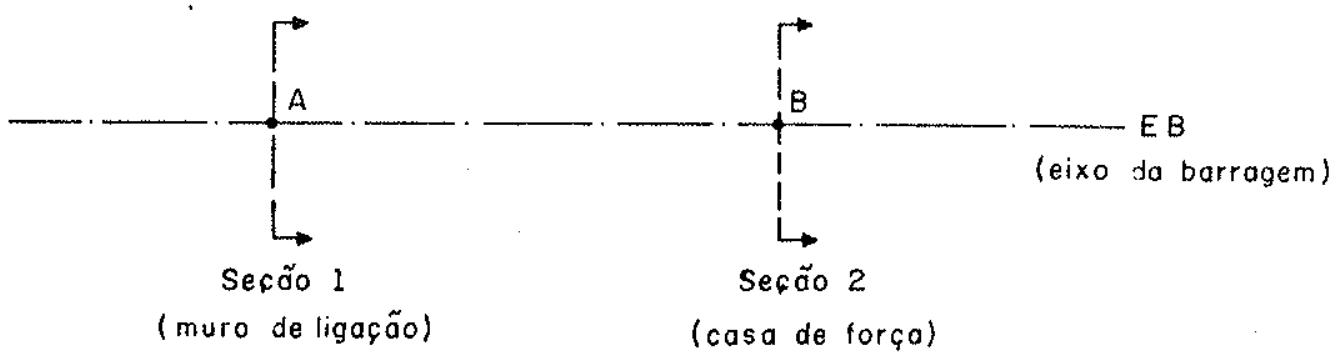

20) Traçado das duas seçros

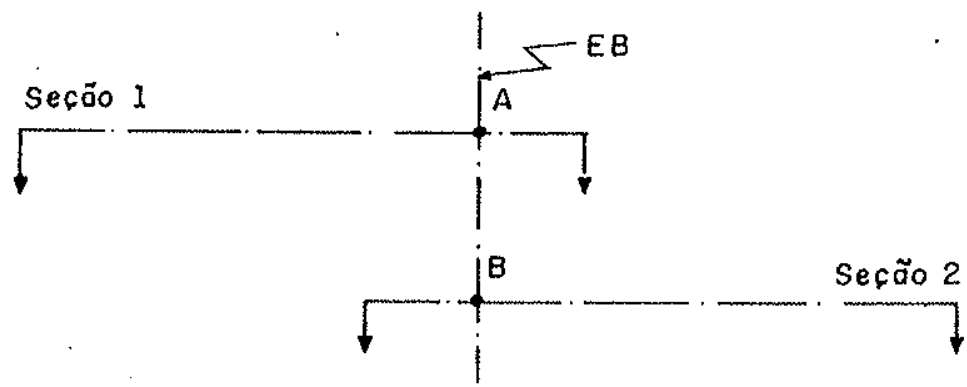

39.) Deslocamento para apresentação numa única sefão

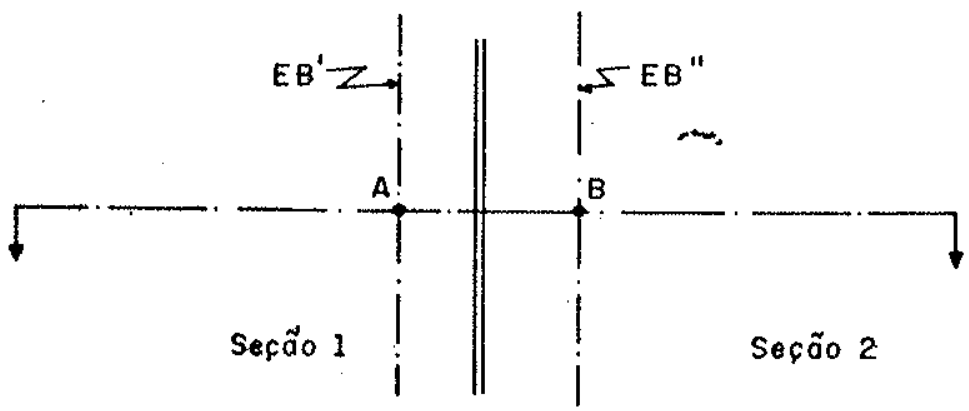



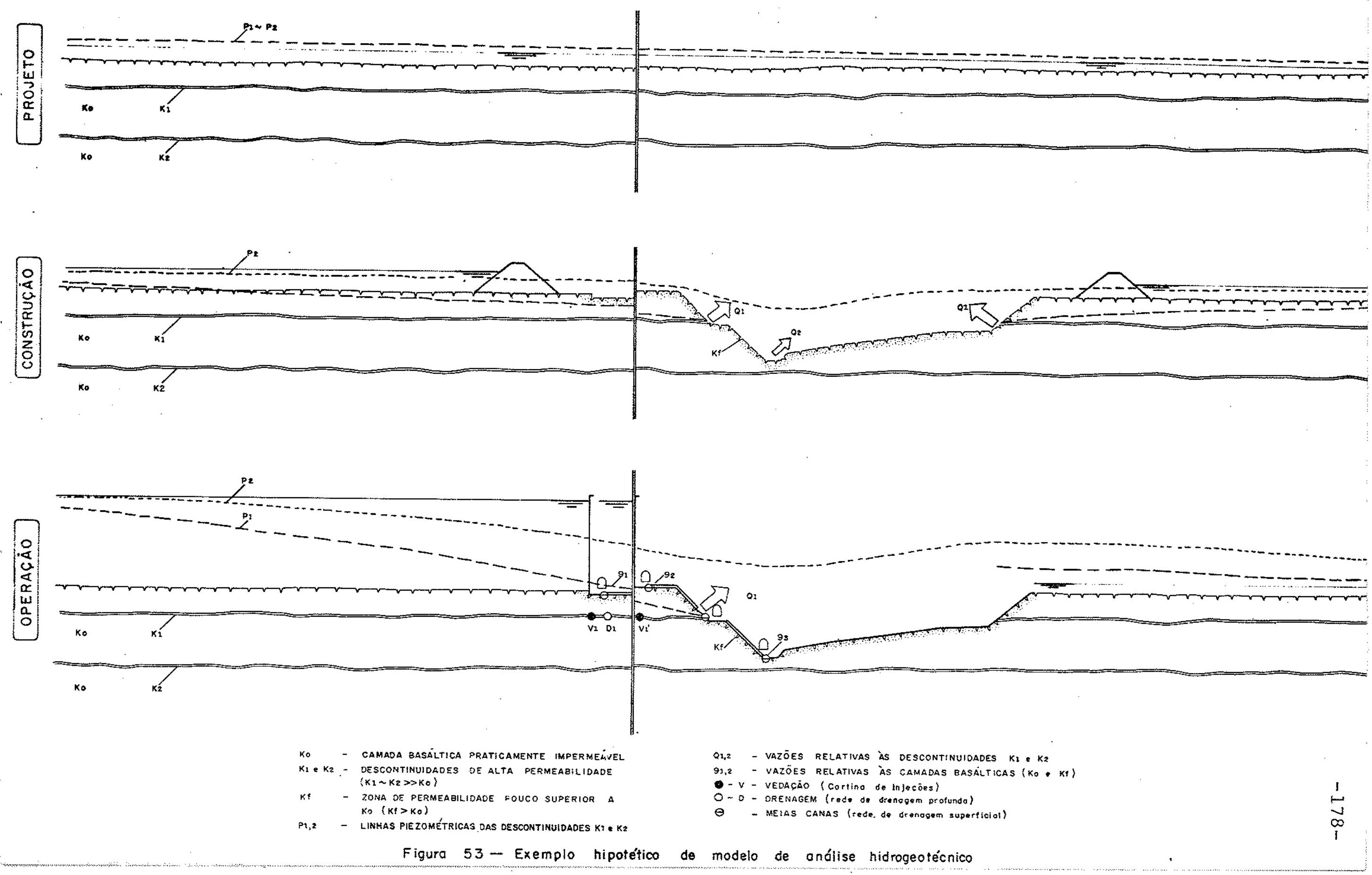

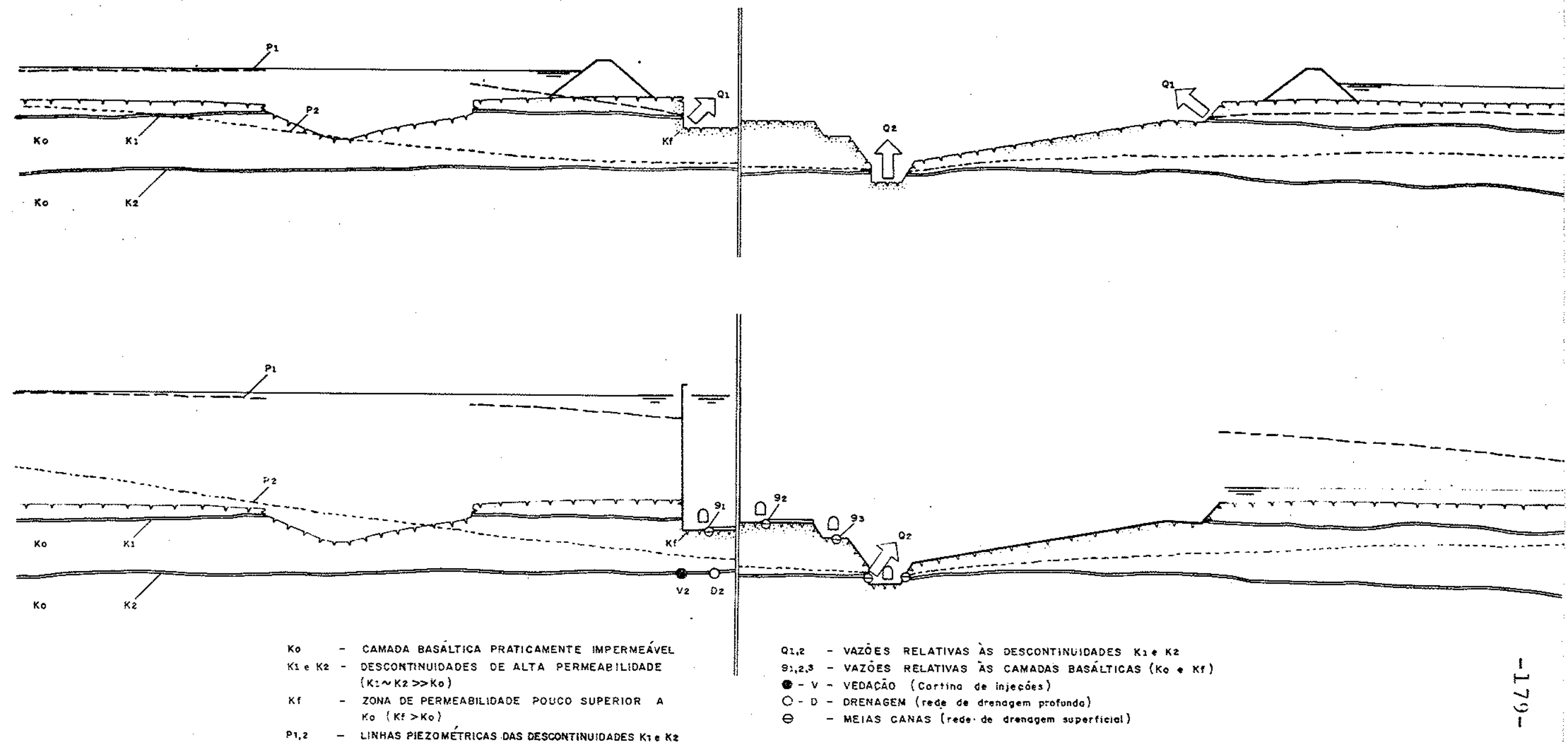

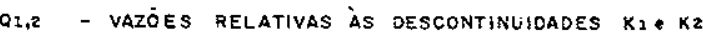

$9: 2.3$ - VAZOEES RELATIVAS AS camadas basálTICAS (Ko * Kf

- - v - vedacäo (Cortino de injecoes)

O- D - DREMAGEM (rede Ge drenagem profunda)

$P_{1,2}$ - LINHAS PiEzométricas Das DESCONTINUTDADES Ki $\mathrm{K}$

- DREMAGEM (rede Ce drenagem profunda)
- meIAS canas (rede de drenagem supartieiel) 
As questões principais podem ser as seguintes:

- I a série de modelos (etapa de construção):

- Quais serão as distribuições de carga piezométrica nas des continuidades ?

- Quais serão as vazões futuramente apresentadas pelas descon tinuidades interceptadas pelas escavações ?

- 2 a série de modelos (etapa de enchimento e operação)

- Quais serão as subpressões que se instalarão sob as estrutu ras de concreto em cada uma das descontinuidades e no contá to $\mathrm{RC}$ no caso de não se fazer nenhum tratamentö profundo das fundações ?

- Quais serão as vazões totais e aquelas correspondentes às descon tinuidades?

- No exemplo da figura 53, quais os quadros hidrogeotécnicos que se estabelecerão jogando-se com as alternativas de veda ção propostas $V_{1}$ e $V^{\prime}{ }_{1}$ e drenagem $D_{1}$ na descontinuidade mais superficial ?

- No exemplo da figura 54 como serão os quadros hidrogeotécni cos com os tratamentos $\mathrm{V}_{2}$ e $\mathrm{D}_{2}$ propostos ? E somente com a drenagem superficial por meias-canas?

- Tratamentos executados nas descontinuidades mais profundas, dos dois exemplos, de que forma alterariam o quadro hidrogeo técnico?

\section{III. - ORIENTAÇÕES PARA OS TRATAMENTOS DAS FUNDACÕES}

Estas orientações deveriam ser consideradas como decorrentes dos resultados obtidos da aplicação dos estudos hidrogeotécnicos, conforme orientação proposta no item antêrior. Assim, pressupõe-se que as vedaçö́es e drenagens objeto das presentes orientações, te riam sido consideradas necessárias nos estudos precedentes, tendo em vista as conclusões obtidas na $3^{\underline{a}}$ Parte da dissertação. 


\section{III.1. - Vedações}

Considerando-se não ser possivel, em geral, a realização deste tratamento durante e apōs o enchimento do reservatörio, as orienta ções relativas a esta etapa se limitam à auscultação hidrogeotécni ca para avaliação de sua eficiência. Nas etapas anteriores pode-se considerar, além da realização em si das injeções, a fase de proje to das vedações. O quadro da tabela 10 resume as orientações propos tas.

\section{III.2. - Drenagem}

Considerando-se a possibilidade de se complementar este trata mento durante o enchimento do reservatório, pode-se sugexir que a drenagem a ser executada na etapa de construção, seja limitada, es sencialmente, àquela projetada para se assegurar o quadro hidrogeo técnico previsto pelos estudos hidrogeotécnicos anteriores. Esta consideração assume sua maior validade quando o programa de enchi mento leva em conta as condições de percolação nas fundações. o qua dro da tabela 11 resume as orientações propostas. 


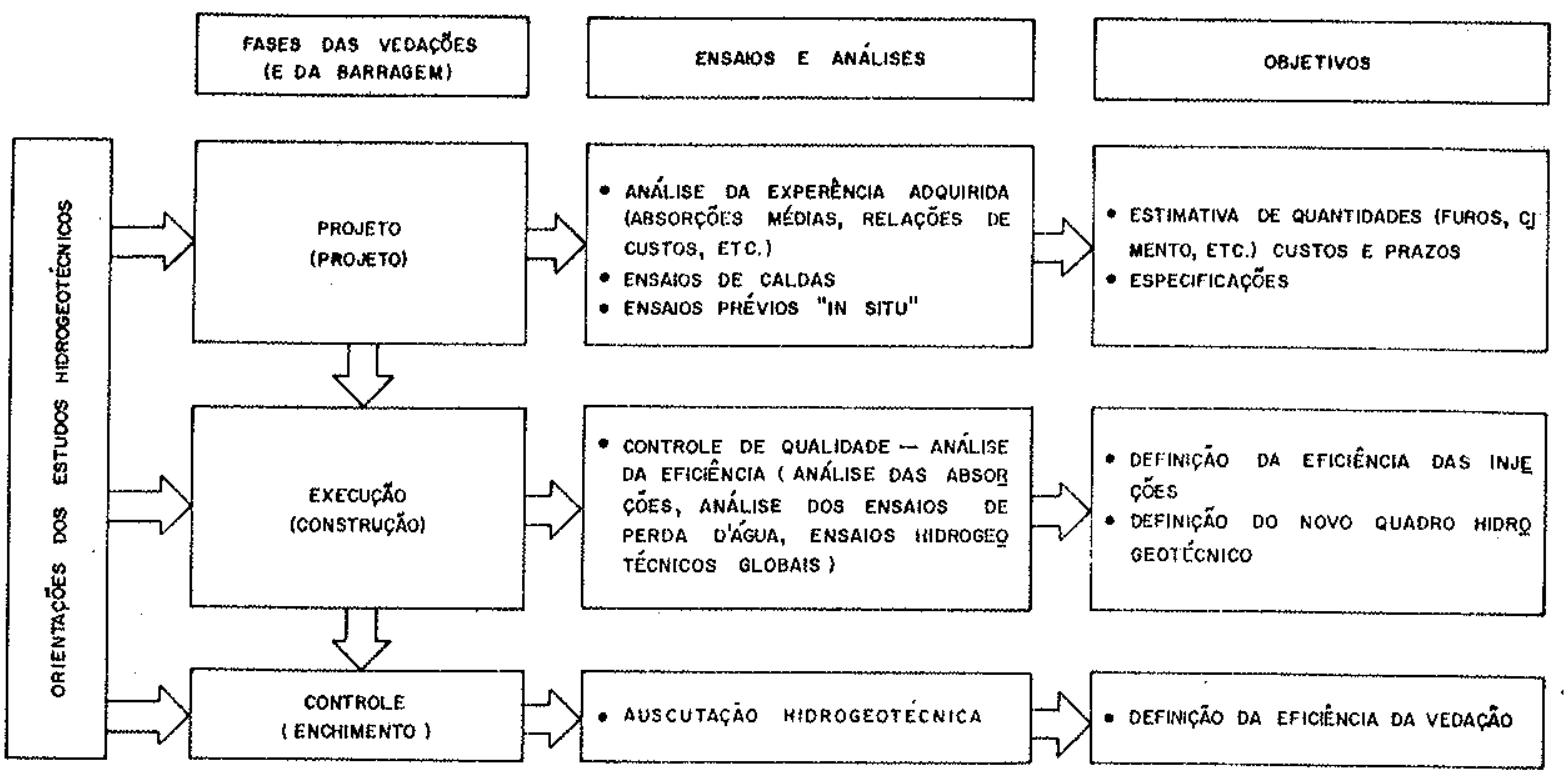

Tabela 10 - Orientações para o projeto, execução e controle das vedações (Modificado de AZEVEDO, OLIVEIRA e SOARES, 1978).

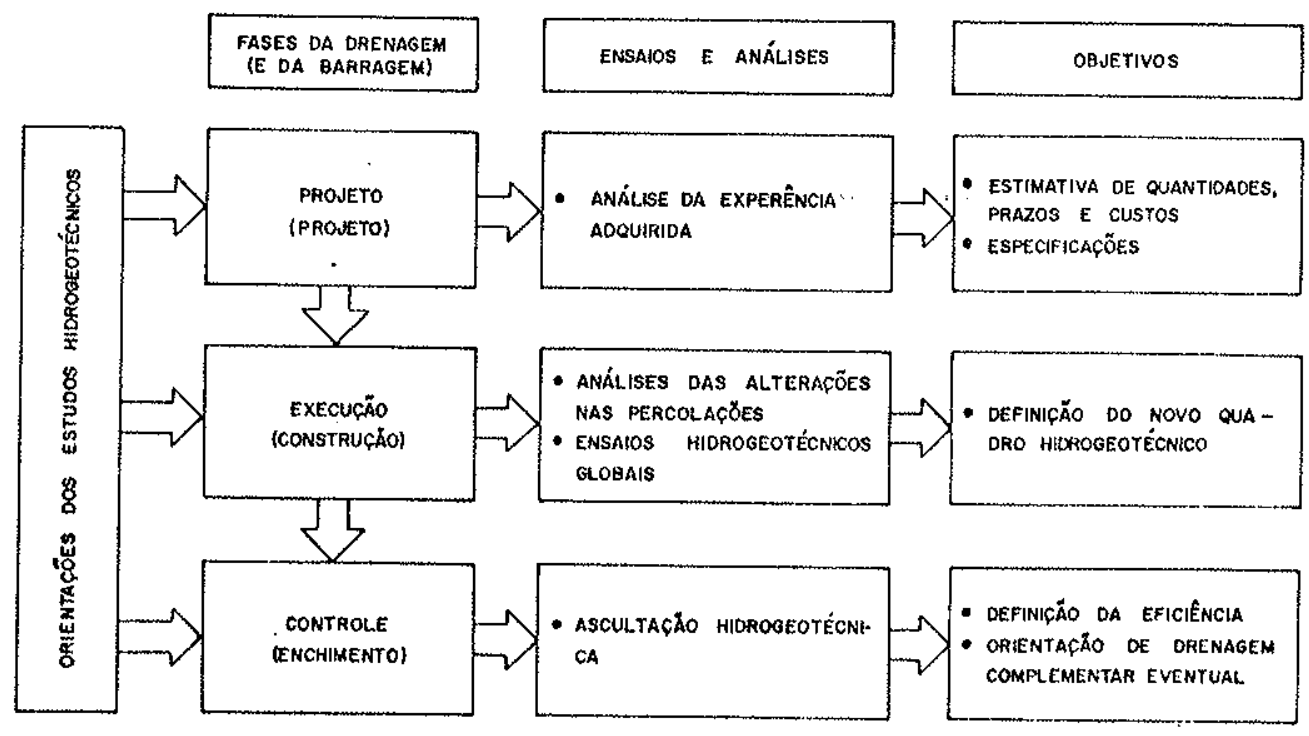

Tabela 11 - Orientações para o projeto, execução e controle de dre gem. 
RESUM 
O autor propõe analisar a questão da percolação d'água em ma ciços rochosos para projetos de grandes barragens segundo um refe rencial definido não só pelo tipo de barragem (solicitação ao meio físico) mas também pelo tipo de maciço rochoso de fundação (respos ta provável do meio físico).

O referencial proposto constitui o ponto de partida para os estudos hidrogeotécnicos necessārios à estimativa de subpressões e vazões nas fundações, a serem considerados na elaboração dos proje tos de barragens. Este enfoque se contrapõe à adoção de regras de projeto cujo uso, genërico e imposto pela tradição, constitui um importante obstáculo à evolução do conhecimento técnico nesta área.

A metodologia proposta é aplicada ao caso brasileiro mais fre quente e estudado: barragens do tipo gravidade em basaltos. Os re sultados desta aplicação são traduzidos em termos de orientações mais adequadas aos estudos hidrogeotécnicos. 
A G R A D E C I M E N T O S 
A apresentação desta dissertação de mestrado, ao Instituto de Geociências da Universidade de São Paulo, representa a concretiza ção do esforço de värios colegas que vêm se dedicando ao desenvol vimento da Geologia Aplicada a Obras Civis no Instituto de Pesqui sas Tecnolögicas do Estado de são Paulo.

Assim, cumpre, em primeiro lugar, agradecer a todos os cole gas de trabalho, destacando a contribuição daqueles que mais próxi mos estiveram desta elaboração. Aos colegas Waldir L. Ponçano, Eda F. Quadros e Ricardo F. da Silva agradeço pelo estimulo permanente à conclusão desta dissertação. Especialmente à colega Eda, pelas primeiras criticas aos originais. Ao colega Adalberto A. Azevedo por sua colaboração persistente e paciente no detalhamento de im portante etapa de sua elaboração.

Agradeço também ao próprio Instituto de Pesquisas Tecnolögi cas que mantëm o propósito de favorecer o desenvolvimento de traba lhos como este.

À Fundação de Amparo à Pesquisa no Estado de são Paulo, cuja bolsa de estudos, outorgada em 1970, contribuiu para a realização das primeiras etapas deste estudo.

À colega Maria Conceição Penna Santos, agradeço pela paciên cia e esmero com que datilografou e procedeu às inumeras revisões do texto.

Cabe-me ainda agradecer aos colegas Fernando P. Camargo e Fernando o. Franciss pela apreciação crítica dos originais e con sequentes esclarecimentos. Particularmente, ao colega Fernando, por suas orientações iniciais à minha vida profissional.

Finalmente, destaco o apoio do colega e orientador Dr. José E.S. Farjallat pela observação cuidadosa da elaboração da presente dissertação. 


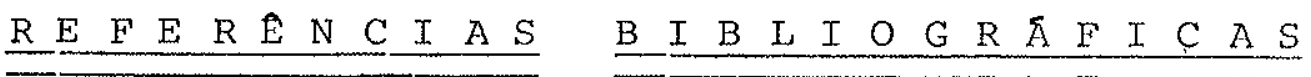


ABGE. Associação Brasileira de Geologia de Engenharia. 1977. Diretrizes para execução de sondagens. ( 2 a tentativa). São Pau 1o, 24 p. (ABGE. Boletịm 3).

AB'SABER,A.N.. 1955 . Bacia Paraná - Uruguai, estudo de geomorfo logia aplicada. In: ASSOCIAÇÃO DOS GEOGRAFOS BRASILEIROS. Condi ções geográficas e aspectos geoeconômicos da Bacia do paraná. Uruguai. São Paulo. v. 1, p. 76-93.

ABRAHÃO,R.A.. 1978. Seepage analyses for Itaipu dam through elec trical analogy. In: SIMPOSIO INTERNACIONAL DE MECANICA DAS RO CHAS, Rio de Janeiro. 1978. Proceedings.... Rio de Janeiro,ABMS. v. 1, p. $129-143$.

AMARAL, G. e outros. 1965. Potassium argon dates of basaltic rocks from southern Brasil. Geochemica et Geochemica Acta, 30:159-189.

ARAUJO,J.S. e outros.1977. A complex structure in basaltic lava flows at Agua Vermelha dam, São Paulo, Brasil.In: INTERNATIONAL SYM POSTUM ON THE GEOTHECNICS OF STRUCTURALLY COMPLEX FORMATION, Itāilia, 1977. Proceedịngs.... Itälia, AGI. v. 1, p. 11-18.

AZEVEDO,A.A.; OLIVEIRA,A.M.S. ; SOARES,L. 1978. Estudo das percola ções em basalto, para o projeto de barxagens de gravidade. In: CONGRESSO BRASILEIRO DE GEOLOGIA DE ENGENHARIA, 2, São Paulo. 1978. Anais.... São Paulo, ABGE. v. 1, p. 65-76.

AZEVEDO,A.A.; OLIVEIRA,A.M.S. ; SOARES,L. 1978. Injeções de vedação em fundações basālticas de barragens de gravidade. In: Corigres SO BRASILEIRO DE GEOLOGIA DE ENGENHARIA, 2, São paulo. 1978. Anais..... São Paulo, ABGE. v. 1, p. 17-33.

BARBOSA, O. 1954. Geológia para túneis e geologia para barragens. Boletin do Departamento da Produção Minera1, Divisão de Geolo gia e Mineralogia. Rio de Janeiro, (90) (Notas preliminares).

BEAR, J. 1972. Dynamics of fluids in porous média. New York, Elsevier. 
BERNAIX, J. 1967. Etude gēotechnique de la roche de Malpasset. paris, Dunod. $212 \mathrm{p}$.

BJORNBERG,A.J.S.; MEISMITH,C.S. 1975. Problemas geológicos de fun dação de barragens sobre basaltos. In: SEMINARIO NACIONAL DE GRANDES BARRAGENS, 10, Curitiba. 1975. Anais.... Curitiba, CBGB. V. 1 .

BJORNBERG,A.J.S.; SANTOS,C.A.F.F.; ZEFES,S. 1980. Decisões técni cas relacionadas com a barragem de Agua Vermelha. In: SEMINARIO NACIONAL DE GRANDES BARRAGENS, 13, Rio de Janeiro. 1980. Anais.... Rio de Janeiro. v. 1, p. 269-292.

Bogomolov, G.V. 1965. Hidrogeologie. Ed. de la Paix, Moscou?

BOLLO,M.F.; RIVET,J. 1968. Progres recents pour l'auscultation des eaux souterraines. In: INTERNATIONAL SYMPOSIUM ON ROCK MECHANICS. Madrid, 1968. Proceedings.... Madrid, Ed. Blume. p. 409-412.

BORDET,C. 1974. Engineering geology related to dam foundations.

In: INTERNATIONAL CONGRESS OF THE INTERNATIONAL ASSOCTATION OF. ENGINEERING GEOLOGY, 2, São Paulo. 1974. Proceedings.... São Pau 1o, ABGE. v. 3, theme 6, p. 286-287. (plenary session).

BOTELHO,H.C. 1966. Tentativa de solução analîtica de alguns proble mas de injeção de cimento em rocha. In: CONGRESSO BRASILEIRO DE MECÃNICA DOS SOLOS, 3, Belo Horizonte. 1966. Anais.... Belo Ho rizonte, ABMS. v. 1, tema $5, p .1-22$.

BORDEAUX, G.H.R.M. e outros. 1975. Instrumentação e anālise das sub pressões na barragem de porto Colombia. In: SEMINARIO NACIONAL DE GRANDES BARRAGENS, 10, Curitiba, 1975. Anais.... Curitiba, CBGB. v. 2 , p. $387-402$.

BRITO, S.N.A. 1971. Feições geológicas no basalto da barragem de Volta Grande. In: SEMINARIO NACIONAL DE GRANDES BARRAGENS, 7 , Rio de Janeiro. 1971. Anais.... Rio de Janeiro, CBGB. v. 1. 
CAMARGO,F.P. 1969. Geologia aplicada a barragem de Ilha solteira. In: SEMANA PAULISTA DE GEOLOGIA APLICADA, 1, São paulo. 1969. Anais.... São Paulo, APGA. v. 3, tema 3.

CAMARGO,F.P. 1976. Geologia de Engenharia. Construção Pesada, 6 (61): 101-102, fev. 1976 .

CAMBEFORT, H. 1964. Injections des sols. Principes et méthodes. Paris, Eyrolles. 393 p. v. 1 .

CASAGRANDE, A. 1961. Controle da percolação através da rocha. Revís ta Água e Energia Elétrica. São Paulo.

CASTANY, G. 1963. Traité pratique des eaux souterraines. Paris, Dunod, 661 p. il.

CRUZ,P.T. 1976. A busca de um método mais realista para a análise de maciços rochosos como fundações de barragens de concreto. In: SEMINARIO NACIONAL DE GRANDES BARRAGENS, 11, Fortaleza. 1976. Anais.... Fortaleza, CBGB. v. 1, p. 215-273.

CRUZ,P.T.; SILVA,R.F. 1978. Uplift pressures at the base and in the rock basaltic fouridations of gravity concrete dams. In: IN TERNATIONAL SYMPOSIUM ON ROCK MECHANICS RELATED TO DAM FOUNDATIONS. Rio de Janeiro, 1978. Proceedings.... Rio de Janeiro, ABMS. v. 1, tema 3, p. 1-25.

DEERE, D.U. 1968. Geological considerations. In: $\underline{\text { Rock mechanics }}$ in engineering practice. Nova York, John Wiley.

DUFFAUT, P.; LOUIS,C. 1972. L'eau souterraine et l'équilibre des pentes naturelles. In: INTERNATIONAL GEOLOGICAL CONGRESS, 24 , Montreal, 1972. Proceedings.... Montreal, IGC. Secção 13, p. $107-116$.

FARJALLAT,J.E.S. 1975. Comportamento da permeabilidade ao ar de alguns basaltos do sul do Brasil. In: CONGRESSO BRASILEIRO DE 
GEOLOGIA, 28, Porto Alegre, 1975. Anais.... Porto Alegre, SBG. v. 7, p. 113-121. (Publicação IPT, 104).

FARRAN,J.; THENOZ,B. 1965. L'alterabilité des roches, sa prevision. Paris. (ITBTP, 215) .

FERREIRA, C.E.O. 1970. Evolução nos mëtodos das sondagens rotativas em Itha Solteira. In: SEMANA PAULISTA DE GEOLOGIA APIICADA, 2, São Paulo, 1970. Anais.... São Paulo, APGA. v. 1, p. 23-36. FRANCISS,F.O. 1970. Contribuition a l'étude du mouvement de l'eau à travers les milieux fissurēs (Thèse à la Facultē des sciences de L'Université de Grenoble).

FRANCISS,F.O.; BRITO,S.A. 1971. A amostragem integral e sua aplica ção nas barragens de Volța Grande e São Simão. In: SEMINÂRIO NA CIONAL DE GRANDES BARRAGENS, 7, Rio de Janeiro. 1971. Anais.... Rio de Janeiro, CBGB, v. 1 .

FRANCISS,F.O.; ROCHA,M. 1976. Determinação da condutividà̃e hidrāuli ca dos meios fissurados. Revista Latinoamericana de Geotecnia, Caracas, 3 (1).

GILG,B. 1967. Mesures prises pour 1'ameriolation de la estabilité du barrage d'ISola. In: CONGRES INTERNATIONAL DES GRANDES BARRA GES, 9, Istambul, 1967. Compte Rendu...... Istambul, CIGB.

GLOSSOP, R. 1960. The invention and development of injection proces ses. Geotecnique, 10 (3): 91-100, sep/dec 1960/1961.

GUIDICINI,G. 1970. Derrames secundários em basaltos. Boletim da Sociedade Brasileira de Geologia, São Paulo, 19(1): 91-93.

GUIDICINI,G. 1972. Comportamento de maciços basālticos frente ao fenô meno de percolação d'água. São Paulo, EPUSP (Trabalho apresentado no curso Hidrogeotecnia de Maciços Rochosos). 
GUIDICINI,G. 1976. Levantamento bibliogräifico de geotecnia e enge nharia geotécnica no Brasil e sua indexação por palavras-chave (1920-1975). São Paulo, ABGE/IPT.

GUIDICINI,G.; CAMARGO,F.P.;OLIVEIRA,A.M.S. 1970. Diretrizes para a padronização de terminologia e convenções em geologia aplicada. (Trabalho apresentado na Semana paulista de Geologia Aplicada, 2, São Paulo, 1970).

GUIDICINI,G.; CAMPOS,J. de O. 1968. Notas sobre a morfogênese dos derrames basálticos. Boletim da Sociedade Brasileira de Geolo gia, São Paulo, $17(1): 15-28$, dez.

GUIDICINI,G.; OLIVEIRA,A.M.S.; MATUOKA, J. 1970. Uplift pressures and deformations at Ibitinga dam foundations, Tiete river, Southern Brazil. In: INTERNATTONAL CONGRESS OF THE INTERNATIONAL ASSOCIATION OF ENGINEERING GEOLOGY, 1, Paris, 1970. Proceedings .... Paris, IAEG. v. 2, p. 1235-1246.

GUIDICINI,G.; USSAMI,A. 1969. Controle da subpressão nas fundą ções da barragem de Jupiā, Rio paranā. In: SEMANA PAULISTA DE GEOLOGIA APLICADA, 1, São Paulo, 1969. Anais.... São Paulo,APGA. v. 2 , tema 3 .

HABIB, P. \& SABARLY,F. 1953. Etude de la circulation de l'eau da:ns un sol pērmeable par analogie éléctrique à trois aimensions. In: CONGRES INTERNACTONAL DE MECANIQUE DE SOLS, 3.

HAUSMAN, A. 1966. Comportamento do freătico nas äreas basāiticas do Rio Grande do sul. Boletim Paranaense de Geografia, Curitiba, $(18 / 19)$

HSU,S.J.C.; RE,G.; ONO,S. 1970. Alguns aspectos sobre o tratamen to de fundações de barragens em obras hidroelētricas. In: SEMA NA PAULISTA DE GEOLOGIA APLICADA, 2, são Paulo, 1970. Anais.... São Paulo, APGA. v. 2 tema 5, p. 409-416. 
IBGE. Instituto Brasileiro de Geografia e Estatistica.. 1977. Geo grafia do Brasil, região Sul, Rio de Janeiro, v. 5.

INSTTTUTO DE PESQUISAS TECNOLOGICAS DO ESTADO DE SÃO PAULO. 1971. Implicações das feicões geolögicas no projeto, construção e com portamento da barragem de Ibitinga. São Paulo. (Relatörio IP', 6113).

INSTYTUTO DE PESQUISAS TECNOLOGICAS DO ESTADO DE SÃO PAULO. 1973. Estudo hidrogeotécnico do maciço rochoso de fundação das estru turas de concreto da barragem de Promissão. São Paulo. (Relató rio IPT, 7164).

INSTITUTO DE PESQUISAS TECNOLOGICAS DO ESTADO DE SÃO PAULO. 1979. Injeções em basalto. São Paulo. (Reiatōrio final, IPT, 12.513). JOHN, K.W. 1974. O 2\% Congresso Internacional de Geologia de Enge nharia (São Paulo, Brasil, 18 a 24 de agosto de 1974, revisão e anālise). Informativo ABGE, São Paulo,...(1). (Apresentado na Tradução do Boletim da IAEG, no 10 ).

JOUANNA, P. 1972. In situ permeability tests under applied stresses. In: SYMPOSIUM ON PERCOLATION THROUGH FISSURED ROCK. stuttgart, 1972. Proceedings.... Stuttgart, ISRM. theme 2-G, p. 1-6. KANJI,M.A. 1970. Relato sobre o téma: Geologia de barragens. In: SEMANA PAULISTA DE GEOLOGIA APLICADA, 2, São Paulo, 1970. Anais... São Paulo, APGA. v. 2, tema 5, p. 351-370.

KANJI,M.A. 1975. Reflexões sobre a geologia de engenharia e as po tencialidades do 19 Congresso da $A B G E$. Informativo $A B G E$, São paulo. (2).

KRSMANOVIC,D.; MILIC,S. 1963. Model experiments on pressure distri buition in some cases of a discontinum. Journal of the Interna tional. Society Rock Mechanics, (1) supl.

LAA, F.; FRANCO,A.M. 1970. Comportment de la fondation de quelques barrages espagnols lors de leur primière mise em charge, fonda 
tion sans voile d'injection. In: CONGRES INTERNATIONAL DES

GRANDS BARRAGES, 10, Montreal, 1970. Compte rendu.... Montreal, CIGB. v. 3, questão 38, p. 141-156.

LEINZ,V. 1949. Contribuição à geologia dos derrames basálticos do sul do Brasil. Boletim da Faculdade de Filosofia Ciências e Le tras, USp. São Paulo. (Geologia, 5).

LEONE,P.C.; RUIZ,M.D. 1970. The importance of grout properties in grouting jointed masses. In: INTERNATIONAL CONGRESS OF THE INTERNATIONAL ASSOCIATION OF ENGINEERING GEOLOGY, 1, Paris, 1970. Proceedings.... Paris, IAEG. v. 1, p. 616 .

LONDE, P.; SABARLY,F. 1966. La distribution des permeabilités dans les fondations des barrages voûtes en fonction du champ de con traintes. In: CONGRESS OF THE INTERNATIONAL SOCIETY OF ROCK MECHANTCS, 1, Lisboa, 1966. Proceedings....Lisboa, LNEC. v. 2, p. 517-522.

LoUIS,C. 1967. Etude des écoulements d'eau dans les roches fissurēs e de leur influence sur la stabilité des massifs rocheux. Bulle. tin de la Direction des Etudes et Recherches, Paris, (3): p. 5-132, 1968. (Thèse Doct. Université Karlssruhe).

LOUIS,C. 1970. Hidraulic triple probe to determine the directional hydraulic conductivities of porous on jointed media. s.l. Impe rial College (Rock. Mech. Res. Rep. GB, Dl2).

LOUIS,C. 1972. Les caractéristiques du massif de fondation du barrage de Grand Maison Bulletin BRGM, (4), seção III. LOUIS,C. 1974. Introduction à l'hidraulique des roches. Orleans, BRGM .

LUGEON,M. 1933. Barrages et geologie. Paris, Dunod. 
MAINI,Y.N. 1971. In situ hydraulic parameters in jointed rock, their measurement and interpretation. London. (Thesis, Ph. D. Imperial College).

MARQUES FILHO,P.L.; WAKATSUKI,S.; OLIVEIRA,R.M. 1972. Usina Hidrelë trica Salto Osōrio: comentários sobre o tratamento de fundações. In: SEMINARIO NACIONAL DE GRANDES BARRAGENS, 8, São Paulo, 1972. Anais.... São paulo, CBGB, v. 1, p. 76-128.

MARY,M. 1965. Les barrages. Paris, Presses Universitaires de France. 125 p. (Que Saije, 1183).

MELLO,V.F.B. 1966. Acidentes em barragens. In: CONGRESSO BRASILEI RO DE MECÁNICA DOS SOLOS, 3, Belo Horizonte. 1966. Anais..... Belo Horizonte, ABMS, v. 1, tema 5, p. 54-73.

MELLO,F.M. de. 1974. Ensaios de campo de verificacão das condições de maciços rochosos em fundacão de barragens para tratamento por injeções. Rio de Janeiro. 138 p. (Tese de mestrado. Institu to de Geociências - UFRJ).

MOLER,W.A.; CABRERA,J.C. 1976. Características de fundações sobre rochas basālticas. In: CONGRESSO BRASILEIRO DE GEOLOGIA DE ENGE ' NHARIA, 1, Rio de Janeiro, 1976. Anais.... Rio de Janeiro,ABGE. v. 2, p. 197-216.

MONTICELLI, J.J. ; GERALDO,A.; SOARES,L. 1978. Rotary drilling equipment used in large dams in Brasil. In: INTERNATIONAL ASSOCIATION OF ENGINEERING GEOLOGY, 3, 1978. Madrid. Proceedings.... Madrid, IAEG. v. 1, seção 4, p. 49-60.

MOURA FILHO,O.; SORREGOTTE,C. 1975. Prospecção do maci.ço rochoso para fundação das estruturas de concreto, Usina de Água Verme Tha, Rio Grande. In: SEMINARIO NACIONAL DE GRANDES BARRAGENS, 10, Curitiba, 1975. Anais..... Curitiba, CBGB. 
NUSKE,M.J. 1970. Características hidrogeológicas do maciço rochoso de Ilha Solteira. In: SEMANA PAULISTA DE GEOLOGIA APLICADA, 2, São Paulo, 1970. Anais..... São Paulo, APGA. v. 1, p. 319.

OLIVEIRA, A.M.S. 1969. Aspectos geológicos do derrame basáltico prin cipal da barragem de Ilha solteira. In: SEMANA PAULISTA DE GEO LOGIA APLICADA, 1, São Paulo, 1969. Anais..... São Paulo, APGA. v. 2, tema 3 .

OLIVEIRA,A.M.S. 1971. Estudos geotécnicose tratamento de fundações de barragens. Relatório geral dos resultados de estágio para aperfeiçoamento, realizado na França. São Paulo, IPT. .

OLIVEIRA, A.M.S. ; CORREIA FILHO,D. 1976. Acompanhamento hidrogeo técnico da barragem de Promissão. In: SEMINARIO NACIONAL DE GRANDES BARRAGENS, 11, Fortaleza, 1976. Anais.... Fortaleza, CBGB， v. 2, p. 753-772.

OLIVEIRA,A.M.S.; SILVA,R.F.; GUIDICINI,G. 1976. Comportamento hi drogeotēcnico dos basaltos em fundações de barragens. In: CON GRESSO BRASILEIRO DE GEOLOGIA DE ENGENHARIA, 1, Rio de Janeiro. . 1976, Anais.... Rio de Janeiro, ABGE. v. 2, p. 413-430.

OLIVEIRA,A.M.S.; SILVA,R.F.; FERREIRA JUNIOR, J. 1975. Ensaios de perda d'água sob pressão, diretrizes. Boletim ABGE, são Paulo, (2).

OLIVETRA,F.E.; SILVA,C.M.; LIMA,F.W. 1966. Estudo de percolação em fundaçöes de barragens por meio de isötopos radioativos. São Paulo, Laboratório de Hidräulica da EPUSP/DAEE/IEA.

PENA, H. e outros. 1970. Injection, drainage et auscultation hydrau lique dans les fondations du barrage de Rapel. In: CONGRES INIER NATIONAL DES GRANDS BARRAGES, 10, Montreal, 1970. Compte Rendu..... Iontreal, CIGB, v. 2, questão 37, p. $651-682$. 
PICHLER,E. 1954. Diretrizes para o estudo geológico de barragens. São Paulo, IPT. (Publicação IPT, 507).

QUADROS,E.F. 1981. Estudo experimental sobre o escoamento da àgua em fraturas rochosas. São Paulo. (Dissertação de Mestrado. Esco la Politēcnica - USP).

RAT,M. 1974. Les caractēristiques principales de l'hiarogēotēcnique. Bulletin BRGM. Orleans, (4).

RE,G. 1976. O tratamento das fundações da Usina de Ilha Solteira e a anälise do seu comportamento no controle das subpressões. São Paulo, Themag Engenharia. $38 \mathrm{p}$.

REBOUÇAS,A.C. 1976. Recursos hidricos subterrāneos da bacia do pa ranā; análise de prē-viabilidade. São Paulo. (Tese de Juivre Do cência. Instituto de Geociências - USP).

ROCHA, M. 1971. Método para amostragem integral de maciços rochosos. Lisboa, Laboratório Nacional de Engenharia Civil. (Memorea LNEC nㅇ 374).

RUIZ,M.D. 1963. Geologia aplicada à barragem em Jupiá: sistema Uru bupungä. São Paulo, IPT. (Publicação IPT, 699).

RUIZ,M.D. 1969. Problemas relacionados com a geologia da barragem de Barra Bonita. São Paulo, IPT/CESP. (Publicação IPT, 866). RUIZ,M.D. 1970. Discurso de abertura. In: SEMANA PAULISTA DE GEO LOGIA APLICADA, 2, São Paulo, 1970. Anais.... São Paulo, APGA. v. $1, p \cdot 1-10$

SABARLY,F. 1968. Les injections et les drainages de fondation des barrages en roches peu permeables. Geotechnique, 18: 229-249. Jun. SABARLY,F. 1971. Le rôle de l'eau dans les fondations de barrages. Separata Revue de l'Industrie Minerale, no special, jul. 
SABARLY,F. 1974. Engineering geology related to dam foundations.

In: INTERNATIONAL CONGRESS ON ENGINEERING GEOLOGY, 2, São Paulo, 1974. Proceedings...... São Paulo, ABGE, 3. v, theme 6, p. 307. (Plenary session).

SABARLY,F.; PAUTRE,A.; LONDE,P. 1970. Quelques reflexions sur la drainabilité des massifs rocheux. In: INTERNATIONAL CONGRESS OF THE INTERNATIONAL SOCIETY FOR ROCK MECHANICS, 2, Belgrado, 1970. Proceedings.... Belgrado, ISRM. v. 3, p. 6-12.

SAMPAIO,A.J.M. 1976. Anālise dos tratamentos e das percolaçóes na fundação da soleira do vertedor da barragem de Capivara, rio. Paranapanema. In: SEMINÁRIO NACIONAL DE GRANDES BARRAGENS, 11, Fortaleza, 1976. Anais.... Fortaleza, CBGB. v. 2, p. 773-795.

SANCHES, W.; GUIDICINI,G.; SILVA,R.F. 1975. Condicões de percolação d'ägua na ombreira esquerda da barragem de Ilha Solteira, rio Paraná, utilizando técnicas radioisotópicas. São Paulo. (Publi cação IEA, 389).

SANTOS,A.R. 1976. Por menos ensaios e instrumentações e por uma maior observação da natureza. In: CONGRESSO BRASILEIRO DE GEO LOGIA DE ENGENHARIA, Rio de Janeiro, 1976. Anais.... Rio de Janeiro, ABGE. v. 1; p. 177-186.

SANTOS,P.S.; RUIZ,M.D. 1963. Caracterizacão mineralógica de algu mas argilas que ocorrem em formação basāltica da barragem de Barra Bonita, rio Tietê, estado de são Paulo. São Paulo. (Publi cação IPT, 727).

SCHOELLER, H. 1962. Les eaux souterraines. Paris, Dunod.

SERAFIM,J.L. 1962. Comentärios sobre o artigo de Casagrande. Geotechnique, jun. 
SERAFIM,J.L. ; DEL CAMPO,A. 1965. Intersticial pressures on rock

foundations of dams. Journal of the Soil Mechanics and Foundation Division, ASCE.

SHARP, J.C. 1970. Fluid flow through fissured media. Londres (Thesis, PhD Imperial College).

SILVA,R.F. 1976. Comunicação, mesa redonda sobre hidrogeologia em obras civis. In: CONGRESSO BRASTLEIRO DE GEOLOGIA DE ENGENHARIA, Rio de Janeiro, 1976. Anais.... Rio de Janeiro, ABGE. v. 3, p.302. SILVA,R.F.; ARAUJO,J.S.; MONTICELLI,J.J. 1978. Special "in situ" tests for the determination of permeability conditions. In: INTERNATIONAL ASSOCIATION OF ENGINEERING GEOLOGY, 3, Madrid, 1978. Proceedings..... Madrid, IAEG, v. 1, seção 4, p. 78-90. SIMONDS,A.W. 1951. Final foundation treatment at Hoover dam. Journal of the Soil Mechanics and Foundation Division, ASCE (109). SNOW,D.T. 1965. A parallel plate model of fractured permeable media. Berkeley. (Thesis, PhD. University of California).

TALOBRE, J.A. 1967. La mécanique des roches. Paris, Dunod.

TATAMIYA,C.T. et alii. 1972. Proposta de adoção de uma sistemāti ca de ensaios de caracterização de caldas de cimento usados em injeções. In: SEMINÁRIO NACIONAL DE GRANDES BARRAGENS, 8, São Paulo, Anais.... São Paulo, CBGB, v. 1, tema 1, p. 148.

TER MINASSIAN,W.; SABARLY,F.; LONDE,P. 1967. Comment proteger les. barrages voutes contre la pression de I'eau dans les appuis. In: CONGRES INTERNATIONAL DES GRANDS BARRAGES, 9, Istambul, 1967. Compte Rendu..... Istambul, GIGB. Q. 32, R. 12, p. 185-199. 
TERZAGHI,K. 1929. Efeitos de fatores geológicos secundários sobre a segurança de barragens. In: COMISSÃO INTERESTADUAL DA BACIA PARANA - URUGUAI. Geologia e engenharia de barragens; tradução de Ernesto Pichler. São Paulo, IPT, 1956, p. 33-50.

TERZAGHI, K. 1962. Stability of steep slopes on hard unweathered rock. Geotechnique, dez.

TIZDEL,R.R. 1970. Deformations of rock foundations of high dams after filling reservoir. In: CONGRESS OF THE INTERNATIONAL SOCIETY FOR ROCK MECHANICS, 2, Belgrado, 1970. Proceedings.... Belgrado. v. 3, theme 21 .

VARLET,H. 1966. Barrages reservoirs. Paris, Ed. Eyrolles.

WITHERSPOON,P.A.; NEUMAN, N. 1972. Finite element methods in hydro geology. Orleans, BRGM. (Rapport BRGM, 72).

WITTKE, W. 1973. Percolation through fissured rock. Stuttgart. (Re lato geral sobre o Simpósio).

YOKOTA,J. 1963. Experimental studies on the design of grouting curtain and drainage for the dam Kurobe no 4. Journal of the International Society for Rock Mechanics, New York, 1 (314): 224244 . 